\title{
The role of neutrophils in particle-induced DNA damage in the lung
}

Citation for published version (APA):

Knaapen, A. M. (2002). The role of neutrophils in particle-induced DNA damage in the lung. [Doctoral Thesis, Maastricht University]. Maastricht University. https://doi.org/10.26481/dis.20021107ak

Document status and date:

Published: 01/01/2002

DOI:

10.26481/dis.20021107ak

Document Version:

Publisher's PDF, also known as Version of record

\section{Please check the document version of this publication:}

- A submitted manuscript is the version of the article upon submission and before peer-review. There can be important differences between the submitted version and the official published version of record.

People interested in the research are advised to contact the author for the final version of the publication, or visit the DOI to the publisher's website.

- The final author version and the galley proof are versions of the publication after peer review.

- The final published version features the final layout of the paper including the volume, issue and page numbers.

Link to publication

\footnotetext{
General rights rights.

- You may freely distribute the URL identifying the publication in the public portal. please follow below link for the End User Agreement:

www.umlib.nl/taverne-license

Take down policy

If you believe that this document breaches copyright please contact us at:

repository@maastrichtuniversity.nl

providing details and we will investigate your claim.
}

Copyright and moral rights for the publications made accessible in the public portal are retained by the authors and/or other copyright owners and it is a condition of accessing publications that users recognise and abide by the legal requirements associated with these

- Users may download and print one copy of any publication from the public portal for the purpose of private study or research.

- You may not further distribute the material or use it for any profit-making activity or commercial gain

If the publication is distributed under the terms of Article $25 \mathrm{fa}$ of the Dutch Copyright Act, indicated by the "Taverne" license above, 


\section{The role of neutrophils in particle-induced DNA damage in the lung}

Ad M. Knaapen 
ISBN 90-9016130-9

O Ad M. Knaapen, Maastricht 2002

Omslagillustratie: Ad Knaapen

Omslagrealisatie en Druk: Datawyse Boekproducties, Maastricht

The studies presented in this thesis were performed at the Nutrition and Toxicology Research Institute Maastricht (NUTRIM) which participates in the Graduate School VLAG (Food Technology, Agrobiotechnology, Nutrition and Health Sciences), accredited by the Royal Netherlands Academy of Arts and Sciences.

\section{nitrin} | ivii| |

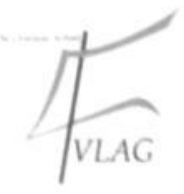




\section{The role of neutrophils in particle-induced DNA damage in the lung}

\section{PROEFSCHRIFT}

ter verkrijging van de graad van doctor aan de Universiteit Maastricht, op gezag van de Rector Magnificus, Prof. dr. A.C. Nieuwenhuijzen Kruseman volgens het besluit van het College van Decanen, in het openbaar te verdedigen op donderdag 7 november 2002 om 16.00 uur

door

\section{Ad Knaapen}

geboren te St.-Geertruid op 19 april 1972 


\section{Promotores:}

Prof. dr. A. Bast

Prof. dr. P.J.A. Borm (Heinrich-Heine University, Düsseldorf, Germany)

\section{Co-promotor:}

Dr. P.F.R. Schins (Institut für umweltmedizinische Forschung (IUF), Düsseldorf, Germany)

\section{Beoordelingscommissie:}

Prof. dr. E.F.M. Wouters (voorzitter)

Prof. dr. J. Bruch (University Essen, Germany)

Prof. dr. C.A. Bruggeman

Prof. dr. K. Donaldson (University of Edinburgh, Scotland, UK)

Prof. dr. F.J. van Schooten

Part of the studies presented in this thesis was financially supported by the Deutsche Forschungsgemeinschaft (Sachbeihilfe: BO1657/2-1).

Het verschijnen van dit proefschrift werd mede mogelijk gemaakt door de financiële steun van de Stichting Dr. Ir. J.H.J. van de Laar. 
Voor pap en mam Voor Janneke 


\section{Contents}

Abbreviations

Chapter 1 General introduction 9

1.1 Particles and inflammation 9

1.1.I Particles 9

1.1.2 Particle deposition and clearance in the respiratory tract 11

1.1.3 Lung inflammation: regulating role of alveolar macrophage and cytokines 12

I.I.4 Neutrophils 14

1.2 Reactive oxygen and nitrogen species 15

1.2.I Terminology of ROS and RNS 15

1.2.2 ROS/RNS generation by phagocytes 16

1.2.3 Effect of particles on ROS/RNS generation by phagocytes or epithelial cells 19

1.2.4 Antioxidant protection of the lung 20

1.3 Particle-related genotoxicity 21

1.3.1 Modification of DNA bases by ROS and RNS 21

1.3.2 DNA repair and DNA strand breaks 23

1.3.3 Detection of DNA damage 24

1.3.4 Consequences of DNA damage 26

1.3.5 Primary genotoxicity of particles 27

1.4 Link between inflammation and carcinogenesis 29

1.4.I Genotoxic effects of inflammatory phagocytes 29

1.4.2 Neutrophilic inflammation in relation to particle-induced genotoxicity and carcinogenicity in the rat 32

1.5 Aim and outline of the thesis 34

References 37

\section{Part 1 \\ Primary genotoxicity}

Chapter 2 Ambient particulate matter induces oxidative DNA damage in lung epithelial cells 49

Chapter 3 Soluble metals as well as the insoluble particle fraction are involved in cellular DNA damage induced by particulate matter 57

Chapter 4 Oxidant-induced DNA damage by quartz in alveolar epithelial cells 71 


\section{Part 2 \\ Secondary genotoxicity}

Chapter 5 Neutrophils cause oxidative DNA damage in alveolar epithelial cells 85

Chapter 6 Mechanisms of neutrophil-induced DNA damage in respiratory tract epithelial cells 97

Chapter 7 DNA damage in lung epithelial cells isolated from rats exposed to quartz: role of surface reactivity and neutrophilic inflammation 109

Chapter $8 \quad$ Summary and General discussion $\quad 129$

Samenvatting 137

Dankwoord/Acknowledgements $\quad 141$

Curriculum vitae 143

List of publications 145 


\section{Abbreviations}

AAS

AL.

$\mathrm{AM}$

AP

BAL

BALf

Cat

COPD

DAB

DAPI

DFO

dG

DMEM

DMPO

DMSO

DQ12

DSB

EDX

ESR

FCS

HBSS

HPLC-ECD

HPRT

HRPO

IARC

IL.

LDH

LMPA

L.PS

MCP

MGG

MIP

MPO

MTT

8-OHdG

PAH

PBS

PKC

PM

PMA

PMN

PSP

PVNO

RFU

RLE

ROS

RNS

SOD

SSB

TNF

TEAC

TMTU

Atomic absorption spectometry

Aluminium lactate

Alveolar macrophages

Alkaline phosphatase

Bronchoalveolar lavage

Bronchoalveolar lavage fluid

Catalase

Chronic obstructive pulmonary disease

Diaminobenzidine-tetrahydrochloride

4,6-Diamino-2-phenylindole

Deferoxamine

2'-deoxyguanosine

Dulbecco's modified eagle's medium

5,5-Dimethyl-1-pyrroline- $\mathrm{N}$-oxide

Dimethylsulfoxide

quartz (batch 6, MIU)

Double strand breaks

Energy dispersive $\mathrm{X}$-ray analysis

Electron spin resonance

Foetal calf serum

Hanks' balanced salt solution

High performance liquid chromatography with electrochemical detection

Hypoxanthine guanine phosphoribosyltransferase

Horseradish peroxidase

International Agency for Research on Cancer

Interleukin

Lactate dehydrogenase

Low melting point agarose

Lipopolysaccharide

Monocyte chemotactic peptide

May-Grünwald/Giemsa

Macrophage inflammatory protein

Myeloperoxidase

3-(4,5-dimethylthiazol-2-yl)-2,5-diphenyltetrazolium bromide

8-Hydroxydeoxyguanosine

Polycyclic aromatic hydrocarbon(s)

Phosphate buffered saline

Protein kinase C

Particulate matter

Phorbol-12-myristate-13-acetate

Polymorphonuclear neutrophils

Poorly soluble particles

Polyvinylpyridine- $\mathrm{N}$-oxide

Relative fluorescence units

Rat alveolar epithelial lung cells

Reactive oxygen species

Reactive nitrogen species

Superoxide dismutase

Single strand breaks

Tumour necrosis factor

Trolox equivalent antioxidant capacity

Tetramethylthiourea 


\section{Chapter 1}

\section{Introduction}

The association of chronic inflammation with the development of cancer has been recognised for a long time. In fact, as early as the late 1800 s, Virchow described the appearance of tumours developed at sites of chronic irritation (Virchow, 1860). Currently, there is a large number of clinical data confirming these early observations on inflammation-related carcinogenesis. For example, in humans a high rate of colon carcinomas is closely associated with chronic inflammatory bowel diseases, including colitis ulcerosis (Collins et al., 1987). Similarly, patients with chronic infections such as osteomylitis or decubitus ulcers can develop very aggressive carcinomas (Cruickshank,1963), and urinary bladder cancer is frequently found in patients suffering from urinary tract infection (Kantor et al., 1984). Also in the lung the presence of inflammatory diseases, such as sarcoidosis, fibrosis and COPD, has been associated with a higher risk of cancer development (Skillrud et al., 1986; Alavanja et al. 1992; IARC 1997; Askling et al., 1999).

In general, many sources of inflammation are effective in accelerating cancer development, including inflammatory reactions caused by viruses, bacteria, parasites or particles (Weitzman and Gordon, 1990; Wiseman and Halliwell, 1996). In the mammalian lung, a relation between particle exposure and the induction of inflammation has been clearly established (Greim et al., 2001; Donaldson and Tran, 2002). At the same time, in the rat chronic inhalation of poorly soluble (non-toxic) particles (PSP) has been associated with lung tumour formation, a process in which the particle-induced inflammatory response is recognised as a significant contributing factor (Driscoll, 1996b; IARC 1997; Greim et al., 2001). As for the relation between inflammation and cancer in general, also in particleinduced tumour formation the constant release of reactive oxygen species (ROS) by inflammatory phagocytes provides a possible mechanism by which inflammatory processes and carcinogenesis might be related: ROS may cause genetic alterations in the lung epithelium, which contributes to cancer development (Weitzman and Gordon, 1990). In the following chapter the general mechanisms of particle-induced inflammation, ROS generation and associated genotoxicity will be described, as to provide a useful basis for further reading of this thesis.

\subsection{Particles and inflammation}

\subsubsection{Particles}

During an average human life span, approximately $3 \times 10^{8} \mathrm{~L}$ of air are inhaled. Unfortunately, it is not only clean, fresh air that we breathe and during life we expose ourselves to all kinds of particulate air pollutants. For instance, on days of heavy air pollution each $\mathrm{m}^{3}$ of 'fresh' air may contain particles up to levels of about $100 \mu \mathrm{g}$, whereas inhaled air in occupational settings may contain respirable particles up to some $\mathrm{mg} / \mathrm{m}^{3}$. In general, environmental particles can be defined as any system of solid or liquid particles of sufficiently small 
indicate that the slowed clearance of particles and fibres may also be explained by an impairment of macrophage phagocytosis, especially after exposure to ultrafine particles $(<100$ $\mathrm{nm}$ ) (Renwick et al., 2001). Originally, overload was suggested to be correlated with the total phagocytised particle volume within the macrophage (Morrow et al., 1988). However, currently it is suggested that the total particle surface area is better correlated with an overload situation in the rat and lung tumour formation, than total particle mass or volume (Driscoll, 1996b; Oberdörster, 2001). It needs however to be stressed that particle overload and associated induction of tumours is a phenomenon specific of the rat, and a lung tumour response under similar conditions is generally not or only limited observed in hamsters and mice (Mauderly, 1997; CIIT final report, 2001). In addition, no evidence for overload as observed in the rat was found in humans heavily exposed to dust, i.e. coal miners (Kuempel et al., 2001).

\subsubsection{Lung inflammation: regulating role of alveolar macrophage and cytokines}

Inflammation is a normal response of a tissue to 'inactivate' xenobiotic compounds and is partly intended to promote the repair of the damaged tissue. A key component in the inflammatory reaction is the transport and accumulation of inflammatory phagocytes into the injured tissue. While a great diversity of agents can elicit an inflammatory response in the lung, a common pathway exists which contributes to this recruitment of inflammatory cells. It is not the scope of the this thesis to discuss this mechanism in detail, however a brief introduction of particle-induced inflammation is indispensable.

\section{Tumour necrosis factor}

Pulmonary inflammatory cell recruitment upon inhalation of particles is largely depending on an elaborate network of cytokines, which are specific signalling molecules that regulate inflammatory processes (Elias et al., 1990). In this process, alveolar macrophages (AM) play a pivotal role. Under normal conditions, AM clear most of the invading micro-organisms or particles. However, when AM are overwhelmed, either by the size, the number or the total surface area of the invading particles, they will be activated to release cytokines, eliciting a rapid inflammatory reaction. The major cytokines released by the AM include IL-1, TNF- $\alpha$, IL-6, IL-8 and monocyte chemotactic protein (MCP-1). TNF- $\alpha$ has been recognised as one of the key cytokines, since it is considered to be the initiator of pulmonary inflammation. It can be produced by a variety of cells, including macrophages, monocytes and neutrophils (Carswell et al., 1975; Rich et al., 1989; Djeu et al., 1990a). However in the lung, alveolar macrophages are found to be the major source of TNF- $\alpha$. A central role of these cells in the particle-induced inflammatory reaction was indicated by the discovery that particles of all kinds, including quartz, asbestos and coal dust were able to activate in vitro TNF- $\alpha$ release by alveolar macrophages (Dubois et al., 1989; Driscoll et al., 1990, Gosset et al., 1991, Van Eeden et al., 2001). Moreover, also in particle-exposed rats, mice and humans, TNF- $\alpha$ levels are increased, which contributes to the central role of this cytokine in the particle-induced inflammatory reaction (Piguet et al., 1990; Zhang et al., 1993; Driscoll 1994a; Seiler et al. 2001; Ghio et al., 2001).

\section{Neutrophil recruitment}

One of the key functions of TNF- $\alpha$ is thought to be the regulation of recruitment of polymorphonuclear neutrophils (PMN) from the pulmonary capillary blood. Indeed, a close association was found between the levels of TNF- $\alpha$ in the brochoalveolar lavage fluid (BALf) and neutrophil influx into the lungs (Driscoll et al., 1994a). TNF- $\alpha$ itself is not chemotactic for neutrophils and macrophages, but it can activate the release of several chemotactic cytokines (chemokines) such as interleukin- 8 by macrophages and lung epithelial cells. 
Neutrophil recruitment is characterised by three subsequent steps: adherence, extravasation or diapedesis, and migration (Sibille and Marchandise, 1993; Strieter and Kunkel, 1994). The adherence of PMN to the vascular endothelium is mediated by specific adhesion molecules (Sibille and Marchandise, 1993). Subsequent processes of neutrophil recruitment (extravasation and migration) are controlled by chemokines (Miller and Krangel, 1992; Driscoll 1994b). The most well studied chemokine in humans is interleukin-8 (IL-8), especially known for its chemotactic activity towards neutrophils (Kunkel et al., 1991). Importantly, in rodents the neutrophil chemotactic action of IL-8 is mainly covered by macrophage inflammatory protein-2 (MIP-2).

In the rat, the extensive inflammatory cell influx is a hallmark of particle exposure at overload levels. Numerous studies have demonstrated the association between inflammatory cell influx into the rat lung and the induction of chemokines after particle exposure (Yuen et al., 1996; Driscoll et al., 1996a; Albrecht et al., 2002; Duffin et al., 2001). The effector cells of TNF- $\alpha$-mediated chemokine production, in addition to fibroblasts and the alveolar macrophages themselves, are alveolar epithelial cells (Standiford et al., 1990 \& 1991; Simon and Paine, 1995). Indeed, several studies suggested that these cells could possibly contribute to the inflammatory cell influx by their ability to release chemokines upon direct interaction with particles (Carter et al. 1997; Driscoll et al., 1997; Steerenberg et al., 1998; Schins et al., 2002a) (Figure 2). Nevertheless, the alveolar macrophage seems indispensable in eliciting an inflammatory response. This is clearly demonstrated by experiments in which the rat lung was depleted from alveolar macrophages. In such animals accumulation of neutrophils and accompanying lung injury was found to be significantly reduced (Lentsch et al., 1999). The effect of macrophage depletion on inflammatory processes induced by particles however, has not yet been investigated.

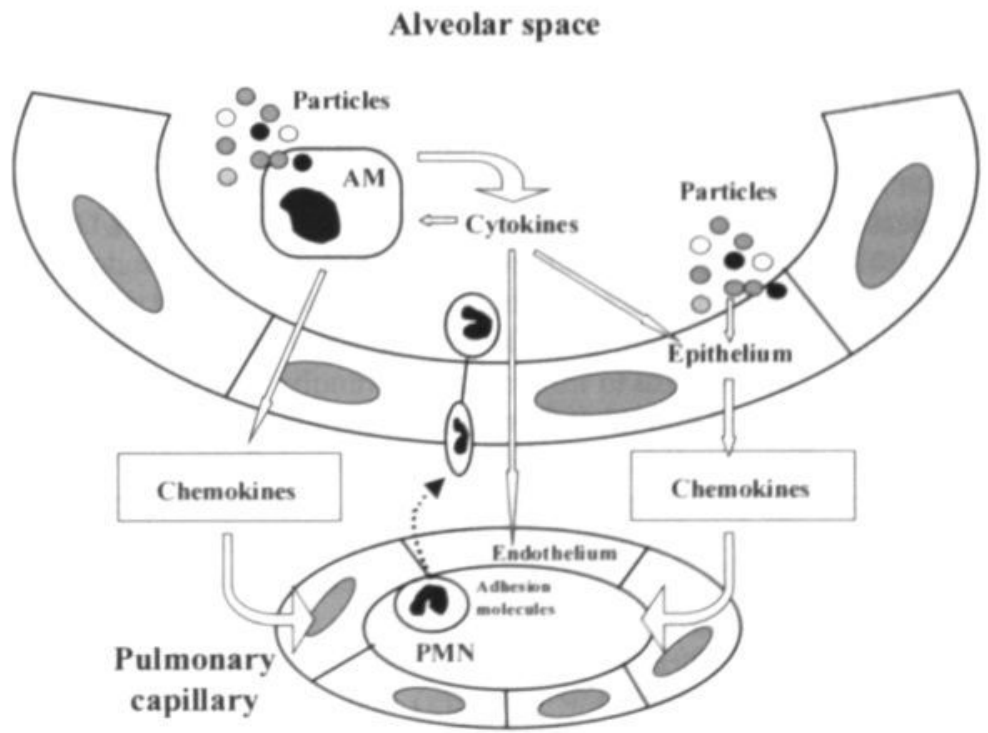

Figure 2. Schematic overview of the interplay between alveolar macrophages (AM), alveolar epithelial cells and blood vessel endothelial cells in the recruitment of neutrophils (PMN) from the pulmonary capillaries into the alveolar space. Particle exposure activates AM to release cytokines, including TNF $\alpha$. These cytokines activate the epithelial and endothelial cells to respectively express chemokines (e.g. IL-8, MIP-2, MCP-1) and adhesion molecules (e.g. ICAM, E-selectin). Marcophages themselves are activated to release chemokines via autocrine pathways. Additionally, particles may also directly activate epithelial cells to release chemokines. 
Various particle characteristics have been identified to be involved in the activation of macrophages and epithelial cells to release cytokines. These may include particle surface reactivity (Donaldson et al., 2001; Albrecht et al., 2002; Duffin et al., 2001), surface area (Li et al., 1999; Brown et al., 2001), presence of soluble metals (Carter et al., 1997; Ghio et al., 2000), and endotoxin (Becker et al., 1996; Soukup and Becker, 2001). It is now generally accepted that target cell release of cytokines such as TNF- $\alpha$ and IL- 8 is closely associated with the ability of the particles to induce oxidative stress. In this mechanism the involvement of redox sensitive intracellular signalling molecules such as nuclear factor $\kappa \mathrm{B}(\mathrm{NF} \kappa \mathrm{B})$ has been clearly demonstrated (Suzuki et al., 1997; Schins et al., 2000; Shukla et al., 2000; Duffin et al., 2001).

In addition to their role in regulating the inflammatory response by the release of cytokines, activated $\mathrm{AM}$ also generate a plethora of other biological active products which are involved in both lung defence and injury. AM release several proteases, including elastases and collagenases that act extracellularly to effect fibrinolysis and matrix remodelling. Enzymes like lysosyme or hydrolases are involved in bacterial killing. Additionally, AM also secrete growth factors, involved in cell proliferation, and biologically active lipid products, such as products of the arachidonic acid metabolism (Sibille and Reynolds, 1990). Last but not least, activated AM also generate ROS and reactive nitrogen species (RNS), which are originally released for bacterial cell killing. Since ROS and RNS may also be involved in cellular genotoxicity, the mechanism of their release by $\mathrm{AM}$ and the role of particles herein will be discussed in paragraph 1.2.

\subsubsection{Neutrophils}

Polymorphonuclear neutrophils (PMN) play an important role in a variety of inflammatory lung diseases. The pulmonary vasculature represents the largest reservoir of PMN in the human body. For instance, the concentration of neutrophils within the pulmonary capillary blood is 35-100 fold greater than within the large vessels of the systemic circulation. Moreover, part of these neutrophils appear to adhere loosely to the endothelial wall of the pulmonary vasculature, even under normal conditions, thereby providing a pool of rapidly 'recruitable' neutrophils (Doerschuk et al., 1987). Deformability of the neutrophils is a crucial factor in this sequestration process (Selby et al., 1991), and recently it has been demonstrated that cytokines, including IL-8 play an important role in decreasing the deformability of the neutrophils, and thus enhancing the sequestration in the lung (Drost and MacNee, 2002). However, in the normal lung lumen, alveolar macrophages are the resident cells, whereas PMN are almost absent. In response to inflammatory stimuli, a very rapid and often massive influx of PMN can be observed into the inflamed lung, as described above. PMN are therefore considered as a major effector cell in both acute and chronic inflammatory processes. Also in particle toxicology the neutrophil has been recognised as a crucial contributing factor in lung injury. Once migrated into the lung lumen, the PMN will be activated to release a myriad of products. Currently, more than 50 neutrophil-derived toxins have been identified including oxygen radicals, proteolytic enzymes, bactericidal proteins and several other enzymes (Weiss, 1989: Sibille and Reynolds, 1990). Most of these products are stored in lysosomal granules, which can be subdevided into azurophil (primary) and specific (secondary) granules. For example, some of the important products stored in azurophil granules are: elastase, lysozyme and myeloperoxidase, while collagenase and defensins can be found in the specific granules (Sibille and Marchandise, 1993). Upon activation, the granules migrate to the cell membrane and fusion with the membrane initiates exocytosis, which is followed by the release of the granule content into the extracellular environment, a process called degranulation. Degranulation by neutrophils can be elicited by several soluble mediators, including the cytokines IL-6, IL-8 and TNF- $\alpha$ (Mullen et al., 1995; Djeu et al., 1990b). Moreover, bacterial 
endotoxins, particles or other noxious stimuli present in the lung lumen are also able to activate the neutrophil degranulation upon phagocytosis (Wilson, 1985; Sibille and Marchandise, 1993). In addition to the release of granule products, activated PMN can undergo a respiratory burst, which is characterised by the production of large amounts of reactive oxygen species. This process, and the role of particles herein will be discussed more in detail in chapter 1.2.

Opposite to their protective role, PMN are also implicated in the pathogenesis of a variety of acute or chronic inflammatory pulmonary diseases including chronic obstructive pulmonary disease (COPD) (Selby et al., 1991; Noguerea et al., 2001), idiopathic pulmonary fibrosis (IPF) (Hunninghake, 1981), and the adult respiratory distress syndrome (ARDS) (Tate and Repine, 1983). In these diseases neutrophils are associated with several pathogenic processes. For instance, PMN-derived oxidants and proteolytic compounds are implicated in a great variety of injurious effects, including lung matrix degradation, killing of pulmonary epithelial and vascular endothelial cells and inducing detachment of these cells from their matrix support (Ward, 1991; Simon et al., 1986). Furthermore, neutrophils have been related to mucus hypersecretion (Adler et al., 1990), whereas oxidants released by neutrophils might play a role in dysregulating airway smooth muscle function, mediating its contractile response (Barnes, 1990; Van der Vliet and Bast, 1992). The specific mechanism of ROS production by neutrophils, and their role in genotoxicity will be further discussed in respectively Chapters 1.2 and 1.3 .

\subsection{Reactive oxygen and nitrogen species}

\subsubsection{Terminology of ROS and RNS}

Reactive oxygen species (ROS) is a collective term often used to describe oxygen radicals, including superoxide $\left(\mathrm{O}_{2}{ }^{\circ}\right)$, hydroxyl radical $\left({ }^{\circ} \mathrm{OH}\right)$, peroxyl radicals $\left(\mathrm{RO}_{2}{ }^{\circ}\right)$ and alkoxyl $\left(\mathrm{RO}^{\circ}\right)$ radicals. Additionally, the term is also used to describe certain non-radicals that are either oxidising species or that can easily be converted into radicals, such as hypochlorous acid $(\mathrm{HOCl})$, ozone $\left(\mathrm{O}_{3}\right)$, peroxynitrite $\left(\mathrm{ONOO}^{\circ}\right)$, singlet oxygen $\left(\mathrm{O}_{2}\right)$ and hydrogen peroxide $\left(\mathrm{H}_{2} \mathrm{O}_{2}\right)$. RNS is a similar collective term that includes nitric oxide radical ( $\left.\mathrm{NO}^{\circ}\right), \mathrm{ONOO}^{\circ}$, nitrogen dioxide radical $\left(\mathrm{NO}_{2}{ }^{\circ}\right)$, other oxides of nitrogen and products of a reaction of $\mathrm{NO}^{\circ}$ with $\mathrm{O}_{2}{ }^{*}, \mathrm{RO}_{2}{ }^{\circ}$ or $\mathrm{RO}^{*}$. An overview is given in Table 1.

Table 1. Overview of reactive oxygen and nitrogen species (ROS and RNS).

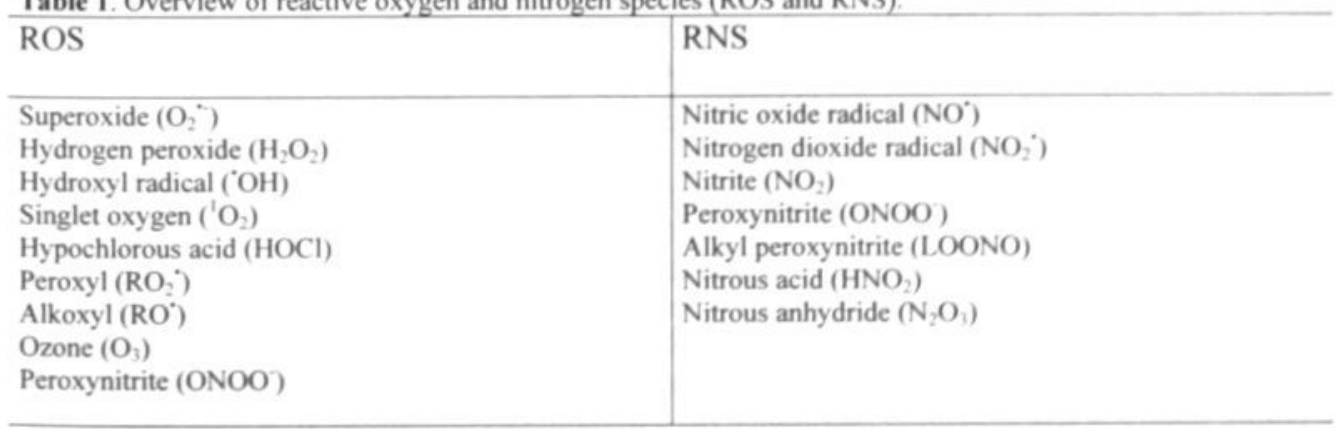


In this context it is important to note that the word 'reactive' is a relative term. For instance, $\mathrm{O}_{2}{ }^{-}$is more reactive than $\mathrm{O}_{2}$, but neither $\mathrm{O}_{2}{ }^{*}$, nor $\mathrm{H}_{2} \mathrm{O}_{2}$ in aqueous solutions is as reactive as ${ }^{\circ} \mathrm{OH}$ (Halliwell and Gutteridge, 1985). The hydroxyl radical is so reactive with biomolecules that a specific scavenger does not exist. As such it seems that damage induced by ${ }^{\circ} \mathrm{OH}$ is unavoidable and that an organism can only deal with it by developing specific repair processes. DNA damage induced by hydroxyl radicals and it repair will be further discussed in Chapters 1.3.1 and 1.3.2.

\subsubsection{ROS/RNS generation by phagocytes}

\section{History}

In cellular systems, endogenous, 'accidental' generation of the most common ROS species $\left(\mathrm{O}_{2}{ }^{\circ}, \mathrm{H}_{2} \mathrm{O}_{2},{ }^{\circ} \mathrm{OH}\right)$ may occur by leaching from mitochondrial respiration. It also includes autooxidation reactions in which $\mathrm{O}_{2}{ }^{*}$ is formed upon reaction of compounds such as catecholamines and ascorbic acid with $\mathrm{O}_{2}$, usually catalysed by transition metals (Halliwell and Gutteridge, 1985). On the other hand, ROS can also be endogenously generated during specific and deliberate synthesis by various cell types, including fibroblasts, vascular endothelial cells and lung epithelial cells (Meier et al., 1990; Arroyo et al., 1990; Van Klaveren, 1997; Kinnula et al., 1991 \& 1992). The most significant and important cellular ROS/RNS generating system in the lung is constituted by the pool of inflammatory phagocytes. In course of their defence activities they produce a vast amount of oxidants that not only kills invaders but also may harm nearby host tissues. The role of phagocytes in host defence was first discovered in the late 1800s by Elie Metchnikoff, who observed that 'wandering' cells crowded around sharp thorns which he had pierced into transparent starfish larvae (Metchnikoff, 1883). However, the first observation that oxygen species might have something to do with the defending function of phagocytes was the discovery of the 'respiratory burst' in the early 1930's by Baldridge and Gerard (1933). In their experiments they found that neutrophils displayed an immediate increase in oxygen uptake upon exposure to bacteria. In the following years, intensive research was performed to elucidate the implication of this respiratory burst. The initial explanation of the increase in oxygen consumption was attributed to the extra need of oxygen to supply energy for ingestion of the microorganisms. However, this hypothesis was roughly rejected by the discovery that these activated neutrophils produced hydrogen peroxide (lyer et al., 1961). The next step in elucidating the mechanism of ROS production by inflammatory phagocytes was the discovery of the enzyme myeloperoxidase by Klebanoff, who showed that this enzyme catalysed the reaction between $\mathrm{H}_{2} \mathrm{O}_{2}$ and $\mathrm{Cl}$ to generate the highly potent microbicidal compound $\mathrm{HOCl}$ (Klebanoff, 1967). In 1973 the mechanism of phagocytic ROS production was further elucidated by the publication of Babior and co-workers about the discovery of superoxide production, catalysed by the enzyme NADPH oxidase (Babior, 1973).

\section{Mechanisms}

The whole spectrum of oxidants initially generated by phagocytes is more or less the responsibility of the action of four different enzymes, catalysing different reactions ( summerised in Table 2). NADPH-oxidase is the enzyme by which the oxidant generation is initiated. It is a membrane-bound enzyme that is dormant in resting cells but comes into action when the cell is activated by phagocytosis of invading microorganims or particles. In addition, also soluble activators, including the inflammatory cytokines IL- 8 and TNF- $\alpha$ are recognised as specific and potent activators of the oxidative burst of neutrophils in the lung (Nathan, 1987: Djeu et al., 1990b). NADPH-oxidase is composed of a number of subunits which are distributed in the cytosol and the membranes of intracellular vesicles and 
organelles. Upon activation the cytosolic subunits migrate to the membranes where they bind to membrane-associated subunits, assembling the active oxidase. The intracellular organelles then fuse with the plasma membrane resulting in the release of $\mathrm{O}_{2}{ }^{*}$ into the extracellular environment or into the phagocytic vesicle (Babior, 1988; Babior, 2000). Currently, the oxidase is thought to be activated via two main pathways: one dependent on $\mathrm{G}$ proteins and formylated peptide receptors, and the other involving protein kinase C (Babior, 1988). The most specific (experimental) activators of both pathways are respectively the bacterial chemotactic peptide $\mathrm{N}$-formyl-methionyl-leucyl-phenylanaline (FMLP) and the phorbol ester phorbol myristate acetate (PMA). Superoxide itself is not very reactive and has a limited membrane permeability. A crucial characteristic is its ability to release iron from specific iron-binding proteins and to reduce $\mathrm{Fe}^{3+}$ to $\mathrm{Fe}^{2+}$, which can subsequently be used in the Fenton reaction, generating hydroxyl radicals (see below) (Bolann et al., 1990; Keyer et al., 1996).

The enzyme superoxide dismutase was first discovered in 1969 by McCord and Fridovich. It catalyses the formation of hydrogen peroxide from superoxide. This reaction is called dismutation, because $\mathrm{O}_{2}{ }^{*}$ reacts with itself to generate an oxidised and a reduced product (resp. $\mathrm{O}_{2}$ and $\mathrm{H}_{2} \mathrm{O}_{2}$ ). Superoxide also dismutes spontaneously. However, the presence of SOD dramatically speeds up the dismutation reaction (about $10^{4}$ times faster than spontaneous dismutation), keeping the steady state concentration of $\mathrm{O}_{2}{ }^{-}$low (McCord and Fridovich, 1969). $\mathrm{H}_{2} \mathrm{O}_{2}$ is relatively stable and is known for its capacity to diffuse and to cross cellular membranes. As such, this provides a phagocyte the possibility to 'act at a distance'. However, in neutrophils most of the hydrogen peroxide $(>70 \%)$ is consumed by the enzyme MPO, which catalyses the reaction of hydrogen peroxide with halide ions $(\mathrm{Cl}, \mathrm{Br}, \mathrm{I})$ to generate hypohalous acids (Hampton et al., 1998). The principal product of the reaction of MPO with $\mathrm{H}_{2} \mathrm{O}_{2}$ is $\mathrm{HOCl}$, due to the relatively high concentrations of $\mathrm{Cl}^{-}$in body fluids. MPO is a haem enzyme, and is present in exceptionally high concentrations in neutrophils $(5 \%$ of dry weight). Monocytes also contain MPO, but to a much lower extent than neutrophils, and generally this is lost when these cells mature into macrophages. MPO has a strong green colour, characterising the green colour of pus in inflamed tissue. (Klebanoff, 1967 and 1999). The MPO, $\mathrm{H}_{2} \mathrm{O}_{2}$ and chloride combination is a powerful antimicrobial system, due to the extremely oxidising potency of $\mathrm{HOCl}$ (Klebanoff, 1968).

Table 2. Enzymes and reactions involved in oxidant generation by inflammatory phagocytes.

\begin{tabular}{|c|c|c|c|}
\hline Enzyme & Reaction & Product & $\begin{array}{l}\text { Specific } \\
\text { antioxidant/ } \\
\text { Scavenger }\end{array}$ \\
\hline NADPH oxidase & $2 \mathrm{O}_{2}+\mathrm{NADPH} \rightarrow 2 \mathrm{O}_{2}^{*}+\mathrm{NADP}^{*}+\mathrm{H}^{+}$ & $\mathrm{O}_{2}^{*}$ & SOD \\
\hline Superoxide dismutase & $2 \mathrm{O}_{2}{ }^{-}+2 \mathrm{H}^{\prime} \rightarrow \mathrm{O}_{2}+\mathrm{H}_{2} \mathrm{O}_{2}$ & $\mathrm{H}_{2} \mathrm{O}_{2}$ & Catalase \\
\hline Myeloperoxidase & $\mathrm{Cl}+\mathrm{H}_{2} \mathrm{O}_{2} \rightarrow \mathrm{HOCl}+\mathrm{OH}^{-}$ & $\mathrm{HOCl}$ & Taurine \\
\hline Nitric oxide dismutase & $\begin{aligned} \mathrm{L}-\arg +\mathrm{O}_{2}+\mathrm{NADPH} \rightarrow & \mathrm{NO}^{*}+\mathrm{L} \text {-citrulline } \\
& +\mathrm{NADP}^{\circ}\end{aligned}$ & $\mathrm{NO}^{\circ}$ & $\begin{array}{l}\text { Imidazolineoxyl- } \\
\text { N-oxides }\end{array}$ \\
\hline
\end{tabular}

The fourth enzyme, nitric oxide synthase, catalyses the production of $\mathrm{NO}^{\circ}$ from $\mathrm{L}$ arginine, oxygen and NADPH. Generally, there are two forms of the enzyme. The constitutive form ( $\mathrm{cNOS}$ ) produces small amounts of $\mathrm{NO}^{\circ}$ for signalling purposes, and is mainly found in vascular endothelial cells and in the nervous system. In contrast, the inducible form (iNOS) is produced by phagocytes upon specific stimulation and is able to generate large amounts of $\mathrm{NO}^{*}$ (Hevel, 1991; Weinberg, 1995). It is well documented that macrophages generate nitric 
oxide in response to cytokines, LPS or particles, in an iNOS-mediated reaction (Gross et al., 1998; Huffman et al., 1998). In contrast, studies on the activity of iNOS in isolated blood neutrophils have been contradictory and often negative (Padgett et al., 1995; Yan et al., 1994; Klebanoff and Nathan, 1993). However, the neutrophil does not necessarily need its own nitric oxide production to contribute to the formation of RNS, since neutrophil-derived myeloperoxidase may contribute to the formation of various RNS by the oxidation of the stable $\mathrm{NO}^{\circ}$ metabolite nitrite, in the presence of hydrogen peroxide (Van der Vliet, 1997).

The enzymes listed in Table 2 are responsible for the 4 products initially generated by activated phagocytes: $\mathrm{O}_{2}{ }^{*}, \mathrm{H}_{2} \mathrm{O}_{2}, \mathrm{HOCl}$ and $\mathrm{NO}{ }^{\circ}$. However, because of their reactivity, these products will always interact with each other, causing the formation of a myriad of oxidants (See Table 1 and Figure 3).

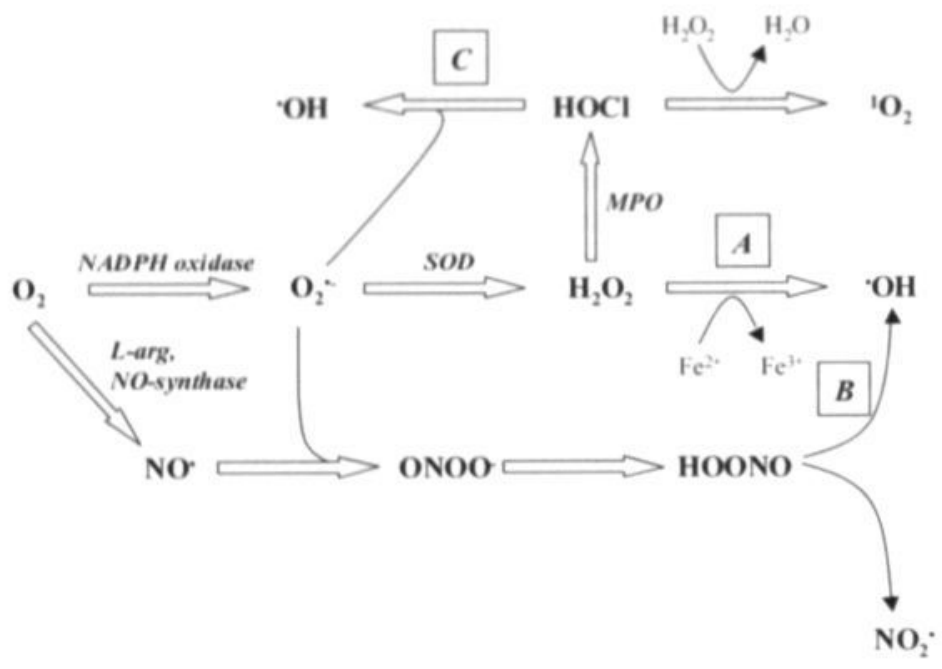

Figure 3. Schematic overview of the generation and interaction of ROS and RNS produced by inflammatory cells. Three different pathways for the generation of ${ }^{\circ} \mathrm{OH}$ are indicated $(\boldsymbol{A}, \boldsymbol{B}, \boldsymbol{C})$.

The most reactive and extensively described secondary product from the initial oxidative burst products is the hydroxyl radical. It can be formed in several ways (see pathways A,B,C in Figure 3), but in biological systems the most significant pathway is probably the Fenton reaction (A), (Fenton, 1894, Lloyd et al., 1997):

$$
\mathrm{Fe}^{2+}+\mathrm{H}_{2} \mathrm{O}_{2} \rightarrow \mathrm{Fe}^{3+}+\mathrm{OH}+{ }^{\circ} \mathrm{OH}
$$

In addition to iron, other transition metals such as Copper, Chromium and Vanadium can also catalyse this reaction (Aruoma et al., 1991; Lloyd et al., 1998). The hydroxyl radical is so reactive that it reacts with almost everything with second order rates of $10^{9}$ to $10^{10} \mathrm{M}^{-1} \mathrm{sec}^{-1}$. Essentially, this means that if ${ }^{\circ} \mathrm{OH}$ contacts a compound, reaction occurs immediately. In addition to its role as a progenitor of $\mathrm{H}_{2} \mathrm{O}_{2}$, and thus the hydroxyl radical, $\mathrm{O}_{2}{ }^{-}$can react extremely fast, at a near diffusion limited rate, with $\mathrm{NO}^{\circ}$ to form peroxynitrite (Huie and Padmaja, 1993). The rate constant of this reaction is about 3.5 times larger than that for the SOD-catalysed dismutation of $\mathrm{O}_{2}{ }^{-}$, suggesting that the $\mathrm{NO}^{*} / \mathrm{O}_{2}{ }^{-}$-reaction may predominate 
over the $\mathrm{O}_{2}{ }^{-} / \mathrm{O}_{2}{ }^{-*}$-reaction (Beckman, 1990). As such, $\mathrm{O}_{2}{ }^{-}$might be considered as a specific endogenous scavenger of $\mathrm{NO}^{*}$. This might have deleterious effects, since $\mathrm{NO}^{*}$ is also known to act as a vascular relaxing factor and is thus involved in controlling blood pressure (Kojda and Harrison, 1999). Although peroxynitrite is not a free radical, it is short lived and far more reactive than both of its precursors. At physiological $\mathrm{pH}$, its protonated form $(\mathrm{ONOOH}) \mathrm{can}$ rapidly decompose to form a variety of highly reactive RNS, including $\mathrm{NO}_{2}{ }^{\circ}$ (Pryor and Squadrito, 1995). More importantly however, $\mathrm{ONOO}^{-}$can be an alternative source for the hydroxyl radical (Beckman et al., 1990; Murphy et al., 1998) (Pathway B, Fig. 3). A third source of ${ }^{\circ} \mathrm{OH}$ formation can be the reaction of $\mathrm{HOCl}$ with $\mathrm{O}_{2}{ }^{-}$(Pathway C, Fig. 3) (Halliwell and Gutteridge, 1985; Ramos et al., 1992).

\subsubsection{Effect of particles on ROS/RNS generation by phagocytes or epithelial cells}

Numerous studies have demonstrated the ability of environmental particles and fibres, including asbestos, crystalline silica, heavy-metal containing dusts, oil fly ash, coal fly ash and ambient particulate matter (PM), to activate ROS release by neutrophils as well as macrophages (Hansen and Mossman, 1987; Hedenborg and Klockars, 1989; Leanderson and Tagesson, 1992; Berg et al., 1993; Becker et al. 1996; Hitzfeld et al., 1997; Prahalad et al., 1999).

Several specific particle characteristics have been demonstrated to be involved in the activation of the inflammatory cells. For mineral dusts such as crystalline silica it has been shown that ROS release from inflammatory cells was related to the physical dimensions and the surface based radical-generating properties of the particles (Vallyathan et al., 1992). For instance, procedures used to modify the particle surface, such as grinding or coating of the surface by specific compounds clearly influenced the ROS release by the inflammatory cells (Klockars et al., 1990; Nyberg, 1991; Vallyathan et al., 1991; Vallyathan et al., 1992). In chemically complex particles such as particulate matter (PM) or fly ash, the chemical composition has been shown to be clearly related to the ability to activate ROS release. Berg et al.. (1993) demonstrated that in macrophages exposed to metal containing dusts, the release of hydrogen peroxide was correlated with the metal content of the dusts. This was also observed in neutrophils exposed to PM, were ROS release was associated with the insoluble metal content of the particles. Notably, in these studies no relation between soluble metals and neutrophil response was found (Prahalad et al., 1999). Additionally, also organic substances adsorbed on the particle surface of PM have been related to the neutrophils' oxidative burst (Hitzfeld et al., 1997).

The intracellular mechanism of ROS production by inflammatory cells exposed to particles preceding the activation of NADPH oxidase is not yet fully understood. In neutrophils exposed to crystalline silica, oxidant generation by the cells has been related to changes in intracellular calcium (Tuomala et al., 1993a). Moreover, in other studies using quartz, a role of protein kinase $\mathrm{C}(\mathrm{PKC})$ was suggested in the oxidant release by neutrophils (Tuomala et al., 1993b). The same mechanism, i.e. role of PKC and intracellular calcium, has been demonstrated for quartz-exposed alveolar macrophages (Gercken et al., 1996).

As described in paragraph 1.3, also RNS may play a significant role in genotoxic effects induced by activated inflammatory cells. However, release of nitric oxide by neutrophils is still contradictory and it is thought that during inflammation the alveolar macrophages are the major source of nitric oxide in the lung. In vivo exposure of rats to quartz results in a clear increase in iNOS mRNA levels in brochoalveolar lavage cells, which is accompanied with an enhanced $\mathrm{NO}^{\circ}$ production by isolated alveolar macrophages (Castranova et al., 1998; Carter and Driscoll, 2001). Surprisingly, data on $\mathrm{NO}^{\circ}$ production during ex vivo stimulation of alveolar macrophages with quartz have been contradictory, and it was suggested that for $\mathrm{NO}^{\circ}$ release by $\mathrm{AM}$, an interaction between $\mathrm{AM}$ and neutrophils is an 
important factor (Castranova et al., 1998). In contrast to quartz, PM has been demonstrated to directly activate NO production by macrophages in vitro (Diociaiuti et al., 2001), although this may largely attributable to LPS contamination of PM.

In addition to macrophages and neutrophils, epithelial lung cells are an alternative source of ROS and RNS during the pulmonary response caused by particle exposure. Type II epithelial cells possess an NADPH-oxidase like activity, which is implicated in the production of hydrogen peroxide by these cells (Van Klaveren, 1997; Kinnula et al., 1991 \& 1992). Moreover, quartz increased the production of hydrogen peroxide in type II cells (Driscoll et al., 2001). The mechanism of particle-mediated $\mathrm{H}_{2} \mathrm{O}_{2}$ generation in these epithelial cells is not yet clear, although a role of PKC activation or mitochondrial activation could be involved (Perderiset et al., 1991; Driscoll et al., 2001). The respiratory tract epithelium has also been recognised as an important source of nitric oxide, which is closely related to the continuous expression of iNOS (Guo et al., 1995). However, possibly due to the fact that these cells lose their iNOS activity rapidly upon culture in vitro (Guo et al., 1995), a direct effect of particles on $\mathrm{NO}^{\circ}$ production by these cells in vitro has been poorly described.

\subsubsection{Antioxidant protection of the lung}

To combat ROS, the lung contains a broad range of antioxidant defences, which has been extensively reviewed elsewhere (Doelman and Bast, 1990; Kinnula et al., 1995; Rahman and MacNee, 1996). Generally, enzymatic and nonenzymatic antioxidant defences can be distinguished. Additionally, antioxidant mechanisms can be divided in extracellular and intracellular defence systems. The first line of defence against inhaled oxidants are the extracellular antioxidant defence systems present in the epithelial lining fluid (ELF). ELF contains enzymatic antioxidants such as SOD, catalase and glutathione peroxidase, as well as low molecular mass antioxidants, including ascorbate, uric acid, glutathione and alphatocopherol (Van der Vliet et al., 1999). A second line of antioxidant defence is contained within the lung target cells themselves, consisting of both enzymatic and non-enzymatic antioxidant mechanisms. The resistance to oxidants may differ profoundly between various lung target cells, mainly caused by differences in the antioxidant capacity of the particular target cell. For example, rat alveolar type II cells and Clara cells, known to be specific target cells for particle-induced carcinogenicity (Johnson et al., 1987; Nikula et al., 1995; Driscoll et al., 1997a), contain larger amounts of catalase compared to endothelial cells or pleural mesothelial cells. However, in comparison with AM's these levels appear to be rather low (Schraufstätter et al., 1988; Kinnula et al., 1992; Kinnula et al., 1995). Consequently, cell types containing lower levels of catalase show an enhanced sensitivity towards for instance $\mathrm{H}_{2} \mathrm{O}_{2}$-induced DNA damage (Schraufstätter et al., 1988). As such, it is obvious to speculate that the vulnerability of a particular site in the lung is determined by not only the local level and characteristics of oxidant exposure, but also the level and specificity of the antioxidant capacity of the local target cells.

Regarding particle exposure, there is considerable evidence that associated cell injury is mediated through the action of oxidants, either generated by the particles, or by particleactivated inflammatory cells. During particle exposure, lungs specifically upregulate their antioxidant defence systems. For instance, using different mineral particles, it has been shown that the profiles of antioxidant induction in the rat lung were dissimilar, possibly reflecting a particle-specific profile of generated ROS (Janssen et al., 1992). Such data would suggest that characterisation of specific antioxidant profiles in the lung could help to identify specific mechanisms of action of various particles. On the other hand, in the rat, particle exposure is essentially associated with a common inflammatory response. In inflammation-related oxidative stress, induction of antioxidants in epithelial cells of the lung seems to be regulated by cytokines, such as TNF- $\alpha$ and IL-6 (Wong and Goeddel, 1988; Kinnula et al., 1995). 
These observations indicate that the induction of pulmonary antioxidants during particle exposure could be related to the intensity of the particle-induced inflammatory response. However, it needs to be emphasised that antioxidant systems of specific target cells may also be induced in response to a direct contact with particles. This has mainly been demonstrated by in vitro studies, showing changes in both gene expression and activities of antioxidants in particle-exposed lung target cells (reviewed by Driscoll et al., 2002).

\subsection{Particle-related genotoxicity}

The initiation stage of the multistep carcinogenic process is mainly characterised by genotoxic processes, which may lead to irreversible changes in the structure of the genetic material of cells. These changes (mutations) may involve a single gene, a block of genes or even whole chromosomes. The term 'genotoxic' has first been used in 1973 by Hermann Druckrey during a conference on 'Evaluation of genetic risks of environmental chemicals' in Sweden. He stated: "In order to describe the components of chemical interaction with genetic material, the term genotoxic is proposed as a general expression to cover toxic, lethal and heritable effects to karyotic and extracaryotic genetic material in germinal and somatic cells" (Weisburger and Williams, 2000). Currently, numerous studies have been performed to investigate genotoxic properties of all kinds of particles (Review: Schins, 2002b). Especially for the purpose of carcinogenic risk assessment of a particular particle, genotoxicity testing is considered as a valuable tool (Greim et al., 2001). Compared with chemicals, particles form a rather specific group of possible genotoxins, since their behaviour and characteristics, both physical and chemical, are totally different and often very complex. Mainly therefore, the exact mechanisms of particle-induced genotoxicity and possibly related carcinogenicity are currently still incompletely understood. To further complicate matters, it is now established that genotoxic effects of poorly soluble particles in rats are closely associated with their properties to elicit an inflammatory reaction (Driscoll et al., 1996a; Greim et al., 2001). Essentially, the ability to induce inflammation therefore necessitates the discrimination between primary (direct particle-induced) versus secondary (inflammation-induced) genotoxicity of particles. However, in both mechanisms of particle-induced genotoxicity, ROS and RNS are known to play an important role (Schins, 2002b). Therefore, the following chapter describes some general mechanisms by which ROS and RNS may induce damage to the DNA.

\subsubsection{Modification of DNA bases by ROS and RNS}

Until the mid-1980's, the major focus in genotoxicity research was on DNA damage caused by xenobiotic chemical compounds such as PAH's, nitrosamines or aromatic amines. Numerous studies were performed to investigate the relation between the mainly large DNAadducts induced by these compounds and carcinogenesis. Smaller DNA adducts, caused by attack of oxygen metabolites were not yet detectable at that time. However, a major development in carcinogenesis research in the past 20 years has been the discovery of DNA damage induced by ROS and RNS derived from both endogenous and exogenous sources (Marnett, 2000). In the mid 80's Ames and co-workers discovered that oxidised DNA bases were abundantly present in tissues of both humans and rodents (Cathcart, 1984). At the same time it became clear that ROS-induced DNA damage was likely to be involved in carcinogenesis. Indeed, many of the ROS/RNS have characteristics which make them to be considered as possible carcinogens. They can oxidatively attack DNA bases, possibly leading to structural alterations in the DNA, such as base pair mutations, deletions, or insertions, 
which are all commonly observed in mutated oncogenes and tumour suppressor genes (Wiseman and Halliwell, 1996).

The chemistry of DNA damage by several ROS has been well characterised, especially using in vitro systems. Generally, the reactions contributing to ROS/RNS-induced DNA damage are oxidation, nitration, depurination, methylation and deamination (Wiseman and Halliwell, 1996). It is important to note that the reactivity from various reactive species towards the DNA is extremely variable. For instance: whereas superoxide and hydrogen peroxide are thought not to react with DNA at all (Halliwell and Aruoma, 1991; Wiseman and Halliwell, 1996), $\mathrm{O}_{2}$ selectively reacts with the guanine base (Van den Akker et al., 1994). However, the most potent ROS by far to react with DNA is the hydroxyl radical, which generates a multiplicity of products from all 4 bases (Pryor, 1988; Spencer et al., 1995). In 1984 Kasai discovered the DNA lesion 8-hydroxydeoxyguanosine (8-OHdG), which is produced by a hydroxylation of the C- 8 position of the guanine derivate of the DNA (Kasai et al., 1984) (Figure 4). The discovery that $8-\mathrm{OHdG}$ was easily detectable by the use of HPLC with electrochemical detection (Floyd, 1986), made it the most abundantly studied oxidative DNA adduct in carcinogenesis research. The ease with which $8-\mathrm{OHdG}$ could be detected in all sorts of tissues, body fluids etc. led to an overwhelming amount of studies investigating the implications of its induction in both human and animal DNA. These studies have ultimately culminated to a consensus that the presence of $8-\mathrm{OHdG}$ in cellular DNA is considered to be closely related with carcinogenesis (Floyd et al., 1990). Indeed, several studies demonstrated enhanced levels of $8-\mathrm{OHdG}$ in tumerous compared to non-tumerous tissue (Okamoto et al., 1994; Kondo et al., 1999). If 'Science' magazine had started its 'molecule of the year' election in the late 80 's, it would certainly have chosen 8 -OHdG. In addition to $8-\mathrm{OHdG}$, numerous other kinds of ${ }^{\circ} \mathrm{OH}$-modified DNA bases have now been described, including 5-hydroxymethyluracil, 5-hydroxy-uracil, 5-hydroxyadenine, 8hydroxyadenine, 2,6-diamino-4-hydroxy-5-formamidopyrimidine (FAPy-guanine) (Spencer et al., 1995, Wiseman and Halliwell, 1996). However, in contrast to 8-OHdG, the biological implications and significance of these lesions for carcinogenesis are often less well understood.
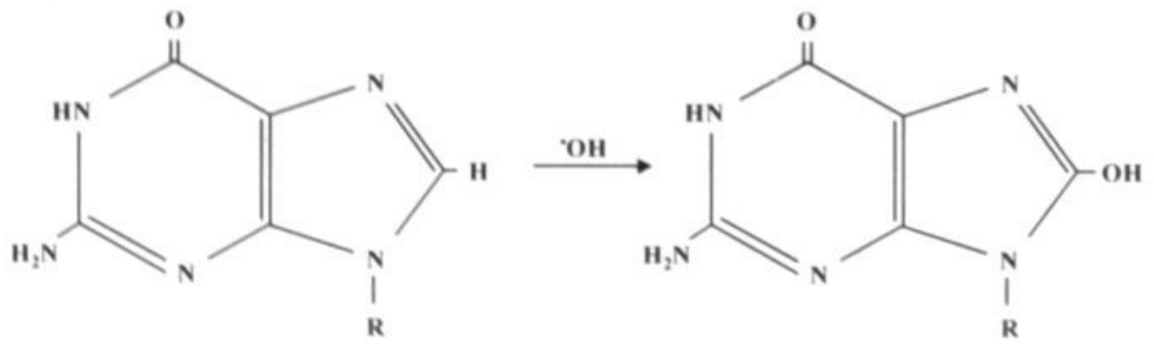

Figure 4. Hydroxylation of the guanine base at the C-8 position by hydroxyl radicals.

Although ${ }^{\circ} \mathrm{OH}$ causes the most significant and abundant DNA base lesions in mammalians, it should be noted that also other ROS and RNS may interact with DNA. HOCl for instance, is shown to react with naked DNA, inducing DNA-protein cross-links or chlorination of DNA bases (Whiteman et al., 1999; Kulcharyk and Heinecke, 2001), although its ability to cause DNA damage in intact cells at physiological concentrations is still controversial (Schraufstatter et al., 1988; Spencer et al., 2000). ${ }^{9} \mathrm{O}_{2}$ is reported to induce 8- 
OHdG in naked DNA (Lutgerink et al., 1992a). However, the implication of this reaction within intact target cells is unclear. In addition to its role as a progenitor of a ${ }^{\circ} \mathrm{OH}$-like species, peroxynitrite is also suggested to damage DNA bases by deamination or nitration (Burney et al., 1999; Tuo et al., 2000). Of the possible DNA base damage products induced by $\mathrm{NO}_{2}{ }^{\circ}, 8$ nitroguanine is identified as the major compound (Yermilov et al., 1995), and also here the biological relevance is thought to be limited, possibly due to efficient repair (Tuo et al., 2000). Nitrite, the major endproduct of $\mathrm{NO}^{\circ}$ oxidation, is demonstrated to induce deaminated guanine and adenine bases in bronchial epithelial cells (Spencer et al., 2000). Additionally, $\mathrm{NO}^{*}$ can also induce DNA base damage via autooxidation to form species such as $\mathrm{N}_{2} \mathrm{O}_{3}$, which damage DNA by deamination of the bases (Nguyen et al., 1992).

ROS and RNS are able to attack all biological macromolecules, i.e they will not only interact with DNA, but will also attack lipids and proteins. Proteins and polyunsaturated fatty acid residues of phospholipids, abundantly present in biomembranes, are extremely sensitive to oxidation. Lipid hydroperoxides are the initial products of oxidised unsaturated fatty acids. Upon reaction with metals they can produce a variety of very reactive side-products, such as epoxides or aldehydes. Among these, malodialdehyde (MDA) and 4-hydroxynonenal are extensively studied. Both products are known to damage DNA (Park and Floyd, 1992; Marnett, 2000), and are associated with mutagenesis (Basu, 1983). Alternatively, interaction of ROS with proteins may cause the induction of covalent cross-links between DNA and proteins, a process also reported to be mutagenic (Kulcharyk and Heinecke, 2001).

\subsubsection{DNA repair and DNA strand breaks}

It is clear that the DNA is constantly exposed to damaging agents such as ROS and RNS. For an individual cell to survive and not to evolve into an uncontrolled growing and proliferating cell, it is an absolute requirement to maintain the integrity of the DNA molecule before initiating DNA replication, DNA transcription and cell division. For that reason, cells are provided with several efficient DNA repair mechanisms. However, the fact that the DNA from tissues of both animals and humans contains a low background level of damaged DNA bases, suggests that the balance between damage and repair is a very fragile one (Ames, 1989). For instance, background levels of damaged DNA bases where found to be increased in a number of inflammatory diseases, suggesting that the normal cellular repair capacity may easily be overwhelmed during situations of excessive ROS generation (Shimoda et al., 1994; Hagen et al., 1994; Bashir et al., 1993).

The major DNA repair mechanisms involved in the removal of damaged DNA bases are nucleotide excision repair (NER) and base excision repair (BER). In addition, several other repair mechanism have been identified, including mismatch repair and DNA alkyltransferases (direct repair). It is however far beyond the scope of this thesis to describe all of these mechanisms. Minor DNA adducts, such as oxidised DNA bases are basically repaired by BER (Hansen and Kelly, 2000). BER involves the removal of relative short stretches of DNA and represents a specific system for the removal of oxidised DNA bases. In BER two different classes of repair enzymes can be distinguished: DNA glycosylases and apurinic/apyrimidinic (AP) endonucleases. DNA glycolases exist for the repair of several DNA base lesions including oxidised, methylated or deaminated bases. These enzymes recognise a specific damaged base and cleave its glycosylic bond, which is followed by the cleavage of the DNA backbone by an AP endonuclease. Subsequently, a new complementary nucleotide is inserted and the backbone is ligated, restoring the native DNA structure (Wallace, 1988). One specific DNA base lesion which is repaired by glycosylases involved in BER is $8-\mathrm{OHdG}$. To counteract the deleterious action of this abundant DNA lesion, most organisms have evolved a specific $8-\mathrm{OHdG}$ repair glycosylase. In humans this is a protein product of the OGG-1 gene (Boiteux and Radicella, 1999). 
Currently, surprisingly few data described the effect of particles on DNA repair mechanisms in target cells. Most research has been done on mineral fibrous particles, and it was shown that OGG-1 proteins and AP endonuclease activities were increased in lung target cells upon exposure to crocidolite asbestos (Fung et al., 1998; Kim et al., 2001). Other studies describe the activation of DNA repair enzymes after treatment with cigarette smoke or diesel exhaust particles (Tsurudome et al., 1999; Kamp et al., 2001). However, the mechanism of DNA repair during exposure to other ubiquitous environmental particles such as quartz or particulate matter, still needs to be investigated. Moreover, it is important to keep in mind that during processes in which target cells are exposed to ROS or RNS, such as during particleinduced inflammation, the cellular response to initial DNA damage can be modulated due to the fact that several ROS/RNS, including $\mathrm{HOCl}$ and $\mathrm{NO}^{\circ}$ are reported to be potent DNA repair inhibitors (Pero et al., 1996; Jaiswal et al., 2001). As a further complication, DNA base damage products, such as $8-\mathrm{OHdG}$ present in DNA have been shown to affect the ability of several restriction endonucleases to cleave the DNA (Turk and Weitzman, 1995).

\section{DNA strand breaks}

DNA strand breakage may result from a variety of reactions. The most obvious way is direct scission of the DNA backbone by chemical or radical attack. There are very few agents that directly break DNA. The best known is ionizing radiation, which induces strand breaks by direct deposition of energy in the ribose-phosphate backbone. Additionally, direct DNA strand breakage can also be induced due to radical attack of the DNA backbone. For instance, DNA strand breaks can be induced upon reaction of ${ }^{\circ} \mathrm{OH}$ with the sugars of the DNA backbone (Eastman and Barry, 1992). DNA strand breakage can also be induced in an indirect manner, via the induction of DNA base damage by ROS or RNS. As described above, such DNA damage will trigger DNA repair mechanisms. However, during their action, DNA strand breaks are transiently introduced into the DNA due to the action of endonucleases, which cleave the phosphodiester backbone of the DNA molecule. Morover, it should be noted that fragmentation of the DNA may also be a result of apoptotic processes (Stewart, 1994).

DNA strand breaks can be categorised as either single-strand (SSB) or double-strand breaks (DSB). SSB normally represent reparable lesions, because the opposite strand holds both ends close together. In contrast however, double strand breaks are usually considered to be lethal, because they are not easily repairable. Anyhow, detection of DNA strand breaks, either directly induced, or transiently induced during repair processes can be considered as a helpful tool to test the genotoxic properties of chemicals and particles. DNA strand break induction activates an abundant nuclear repair enzyme, poly(ADP-ribose) polymerase (PARP). For instance, induction of DNA strand breakage in asbestos-treated mesothelial cells was associated with an activation of PARP (Dong et al., 1995). There is now considerable evidence that this enzyme, which modulates the DNA break rejoining processes, plays a crucial role in the overall response to DNA damage (Satoh and Lindahl, 1994; Stierum, 1996).

\subsubsection{Detection of DNA damage}

\section{Analysis of DNA base damage}

In the past, a number of techniques for the detection of DNA base damage has been developed. For instance, 8-hydroxyguanine (8-OHG), is often measured as the nucleoside (i.e base coupled to a sugar) 8 -hydroxydeoxyguanosine $(8-\mathrm{OHdG})$. To obtain this specific adduct from isolated DNA, the DNA must be hydrolysed using enzymes. 8-OHdG can then be measured using high performance liquid chromatography with electrochemical detection (HPLC-ECD), providing a highly sensitive method (Floyd et al., 1986). Alternatively, also 8- 
OHG can be measured, after releasing it from the DNA by acid hydrolysis. In addition to HPLC, gas chromatography coupled mass spectrometry (GC-MS) with selected ion monitoring is another highly sensitive method to analyse a wide spectrum of damaged DNA bases. Both methods (HPLC-ECD, GC-MS) are very sensitive and have led to an enormous increase in research on oxidative DNA damage. However, the relative rude processing needed to degrade the DNA is currently a point of debate as this may cause both over- and underestimations of the actual levels of DNA damage. Especially for particle research this is an important point. During processing of particle-exposed cells, the naked DNA comes into contact with free particles, possibly leading to an artificial induction of damage. Indeed, incubations with naked DNA have been used to evaluate genotoxic properties of particles such as quartz (Daniel et al., 1993). To avoid unwanted post-experimental interaction of particles and DNA, methods to detect DNA damage in situ can be applied. For instance, with immunohistochemical techniques, using specific antibodies, numerous specific damaged DNA bases can be detected, including 8-OHdG or 8-OHG (Nehls et al., 1997; Toyokuni et al., 1997; Soultanakis et al., 2000). The major advantage of these methods is the relative speed by which results can be obtained, and the fact that no complicated analytical equipment is needed. Moreover, such methods provide the possibility to investigate DNA damage on a single cell level, or to specifically locate DNA damage in tissue sections. However, in contrast to analytical chemical methods a quantitative analysis is not possible.

Another approach to detect specific DNA adducts is the postlabeling method. In this quantitative technique, detection of the DNA-adducts involves the addition of a radioisotope into the adduct. The best known postlabeling method is the ${ }^{32} \mathrm{P}$-postlabeling technique (Randerath et al., 1981), which represents the most sensitive analytical tool for measuring a single base damage in cellular DNA. The technique is especially useful and very sensitive for the detection of bulky aromatic DNA adducts (such as PAH-DNA adducts), allowing detection limits of 1 adduct per $10^{8}$ nucleotides or even lower (Van Schooten, 1991). The ${ }^{32} \mathrm{P}$ postlabeling technique has also been adapted to detect small DNA adducts such as 8-OHdG (Lutgerink et al., 1992b).

\section{Analysis of DNA strand breaks}

In contrast to base damage analysis, DNA strand break analysis may cover a broader range of damaging effects, since strand breaks can either be directly induced or indirectly, mainly due to repair processes after base damage. The most commonly used method for detection of DNA strand breaks is the alkaline elution method (Kohn et al., 1976). In this technique, exposed cells are lysed and DNA is denatured in alkali, and subsequently eluted on a filter. The rate of elution is proportional to the single strand size of the DNA. By varying the pH of the elution buffer, the origin of the strand breaks can be more or less determined. For instance, alkali-labile sites are stable until the $\mathrm{pH}$ is raised above 12.5 , whereas double strand breaks can only be detected when DNA is eluted from the filters at neutral pH (Bradley et al., 1979). A differentiation between DSB and SSB within one DNA sample can be made using supercoiled double-stranded plasmid DNA as a target. After exposure, the DNA can be electrophorised and the relative amount of supercoiled (i.e. undamaged), relaxed (representing damage due to SSB), and linear DNA (representing DSB) can be distinguished (Gilmour et al., 1995). A relative new and interesting technique to measure SSB's is single cell gel electrophoresis, also known as the comet assay (Singh et al., 1988). In this assay, exposed cells are transferred into a gel, lysed, denatured in alkali and subsequently electrophorised. Cells with increased DNA damage display an increased migration of chromosomal DNA from the nucleus to the anode. The term 'comet' is used to identify the DNA migration patterns produced by this assay. A great advantage of this method, compared to the former ones is the possibility to measure the level of SSB on a single cell level, allowing analysis of a small 
number of cells. Also here modification of the $\mathrm{pH}$ of the denaturation/electrophoresis buffer can give additional information about the nature of the SSB. More specifically, the original version of a technique to evaluate strand breaks in individual cells was described by Östling and Johanson (1984), who used neutral conditions, and thus detected DSB's. In the alkaline comet assay, recent adaptations demonstrated that the use of specific DNA repair enzymes or antioxidants prior to denaturation may give additional information about the nature of the DNA damage (Collins et al., 1993; Tice et al., 2000). For instance, the use of formamidopyrimidine-DNA glycosylase (FPG), a bacterial enzyme which specifically repairs 8-OHdG from the DNA, provides a method to detect $8-\mathrm{OHdG}$ with the comet assay which closely resembles the HPLC-ECD method (Yoshida et al., 2001). Alternatively, measurement of Poly-ADP-ribose polymerase activity can be used as an indirect measure of DNA strand breaks, since it is activated whenever DNA strand breaks occur (Althaus et al., 1982).

\subsubsection{Consequences of DNA damage}

DNA damage might have several consequences, such as cell cycle arrest, mutagenicity and eventually cancer. Furthermore, DNA damage is also implicated in cell killing processes. Cytotoxicity is generally used as a term to describe the cell-killing property of a certain compound. In principle, there are two mechanisms involved in cytotoxicity, necrosis and apoptosis. Necrosis is the pathological process which occurs when cells are exposed to a physical or chemical insult. Apotosis however (aka programmed cell death) is the physiological process by which useless cells are eliminated during normal biological processes. Therefore, it could be speculated that the level of oxidative stress necessary to transform a single cell into an uncontrolled growing one, has a sort of optimum: too much of DNA damage will result in death cells, unable to proliferate. In such a way, cytotoxicity, either due to necrosis or apoptosis, can be considered as a defence mechanism of cells to prevent malignant transformation.

To have a possible implication in carcinogenesis, DNA damage has to be related to genes involved in cell proliferation and growth. Damage to 'inactive' DNA will do not much harm as no vital genes are involved. Two types of genes are considered to be of crucial importance in the carcinogenic process. These include protooncogenes (e.g. K-ras) and tumour suppressor genes (e.g. p53). In general, protooncogenes code for protein products involved in growth stimulation, whereas tumour suppressor gene-products regulate growth inhibition. Normally, the activity of these genes is well controlled within the cell. However, genetic alterations (gene-mutations), such as those induced by ROS/RNS may lead to an uncontrolled activation, or respectively inactivation pattern of these genes, eventually leading to an increased cell growth and proliferation. ROS/RNS-induced gene alterations may specifically include point mutations and base deletions (Jackson, 1994). Moreover, is should be noted that ROS/RNS may also induce changes in whole chromosomes (chromosomal mutations or aberrations). However, these processes will not be further discussed in this thesis.

Mutagenic processes associated with DNA base damage have been extensively investigated. Much work, of course, has been done on $8-\mathrm{OHdG}$, and several studies demonstrated that this lesion is indeed premutagenic (Kuchino et al., 1987; Cheng et al., 1992). Moreover, 8-OHdG-specific patters of mutagenesis are widely seen in mutated oncogens and tumour suppressor genes, indicating the association of $8-\mathrm{OHdG}$ with carcinogenesis. Also other ${ }^{\circ} \mathrm{OH}$-mediated DNA lesions such as 8-OH-adenine, thymine glycol, 5-hydroxyuracil and uracil glycol are shown to be mutagenic (Guschlbauer et al.. 1991: Wang et al., 1998). However, the mutational potential of these DNA lesions is variable, with 8 -OHdG being 4 times more mutagenic than for instance 8-OHdA (Tan et al., 1999). In 
addition, also RNS-derived DNA damage has been shown to be mutagenic in a variety of systems, including bacteria and mammalian cells (Burney et al., 1999).

An alternative way by which oxidant-induced DNA damage can affect production of proteins involved in cell proliferation and growth, is by altering the interaction between gene promoters and sequence specific DNA binding proteins associated with these promoters. For instance, the presence of $8-\mathrm{OHdG}$ in consensus binding sequences for transcription factors AP-1, NFkB and Spl was related to an inhibition of the binding of these transcription factors to the DNA (Ghosh and Mitchell, 1999; Ramon et al., 1999).

\subsubsection{Primary genotoxicity of particles}

As opposed to secondary, inflammatory cell dependent genotoxicity (Chapter 1.4), direct particle-induced genotoxic effects will be referred to as 'primary genotoxicity'. In the past, various established test systems have been applied to investigate primary genotoxicity of particles. The most simple test to analyse direct genotoxic effects is to coincubate particles directly with naked DNA in aqueous buffer. Using such systems a variety of DNA damaging properties, including strand breakage and damaged DNA bases have been described for all kinds of particles, including crystalline silica and PM (Daniel et al., 1993; Shi et al., 1994; Donaldson et al., 1997; Prahalad et al., 2001). In general, acellular assays can be considered as a first way to screen genotoxic properties of new particles. However, it is important to realise that these test systems implicate that particles, engulfed by target cells should come into close contact with the DNA. Although Daniel et al. (1995) demonstrated localisation of quartz particles in the nuclei and mitotic spindles of alveolar epithelial cells, the migration of particles into the nucleus and possible related genotoxic consequences is still controversial.

Therefore, the use of cell lines possibly represents a more appropriate way to elucidate mechanisms of particle-induced genotoxicity. In the past a variety of genotoxicity indicator tests have been used to describe cellular particle-induced genotoxic effects in vitro. These include measurement of DNA damage (strand breakage, 8-OHdG), detection of chromosomal aberrations, representing possible clastogenic activity of particles (sister chromatide exchanges, micronucleus), and measurement of gene-mutations (HPRT, Ames-test). A selection of such studies is shown in table 3 . This listing should essentially not be considered as a thorough analysis of existing data, but only intends to give a concise selection of some genotoxic effects of relevant (both 'model' and 'real life') particles. It is also important to note that in vitro studies on reference particles, such as carbon black and titanium dioxide, generally used as negative controls, have demonstrated contrasting results. Although indeed tested negative in the vast majority of studies, also some positive genotoxic results have been described (Table 3 ).

\section{Mechanisms}

Several mechanisms have been proposed to be possibly involved in direct genotoxic effects of particles in vitro. In general, the ability of particles to generate ROS in cell free aqueous buffers is now recognised as a major factor in direct particle-induced genotoxicity (Schins, $2002 \mathrm{~b}$ ). For instance, for quartz the induction of $8-\mathrm{OHdG}$ or DNA strand breaks could be directly linked to its capacity to generate ROS in aqueous suspensions (Van Maanen et al., 1999; Shi et al., 1994). The ability of quartz to generate ROS in cell free systems is largely explained by its reactive particle surface (Vallyathan et al., 1988; Fubini et al., 1990; Fubini, 1998), and its specific role has been investigated using different coating materials or surface modifying processes such as grinding, etching, or heating which affects the hydrophobicity (Liu et al., 1996; Fubini et al., 1998, Elias et al., 2000; Duffin et al., 2001; Schins, 2002b).

Other physico-chemical characteristics related to the pathogenic effects of silica particles are particle size, presence of impurities such as metals, and crystallinity 
(Fubini,1998). Generally, crystalline silica is considered to be more reactive than amorphous silica (Zhong et al., 1997; IARC 1997), although others demonstrated that among several tested silica dusts, some amorphous dusts were as potent as some crystalline dusts (Elias et al., 2000). Although the majority of the studies mentioned above clearly demonstrated the genotoxic potency of quartz, it is important to notify that primary genotoxicity of quartz seems, at least to some extent, to be a point of discussion, since others for instance were not able to detect mutations in the HPRT gene of rat type II cells, or SCE's in human lymphocytes in vitro treated with quartz (Pairon et al., 1990; Driscoll et al., 1997a).

Table 3. Examples of in vitro studies showing primary cellular genotoxic effects of various particles.

\begin{tabular}{|c|c|c|c|}
\hline Particles & Target cells & Genotoxicity endpoints & References \\
\hline Carbon black & $\begin{array}{l}\text { Alveolar epithelial cells, } \\
\text { Monocytes }\end{array}$ & Strand breaks (Comet) & $\begin{array}{l}\text { Don Porto Carero et al., } \\
2001\end{array}$ \\
\hline \multirow[t]{2}{*}{ Titanium dioxide } & Alveolar epithelial cells & 8-OHdG & $\begin{array}{l}\text { Van Maanen et al. } \\
1999\end{array}$ \\
\hline & Chinese hamster ovary cells & Micronucleus, SCE & Lu et al., 1998 \\
\hline $\begin{array}{l}\text { Titanium dioxide } \\
(w i t h(V)\end{array}$ & (Skin) Fibroblasts & Comet & Dunford et al., 1997 \\
\hline \multirow[t]{3}{*}{ Crystalline silica } & Fibroblasts & Strand breaks (Comet) & Zhong et al., 1997 \\
\hline & Alveolar macrophages & Strand breaks (Comet) & Zhang et al., 2000 \\
\hline & Fibroblasts & Micronucleus & Liu et al.. 1996 \\
\hline Coal fly ashes & Alveolar epithelial cells & 8-OHdG & $\begin{array}{l}\text { Van Maanen et al., } \\
1999\end{array}$ \\
\hline $\begin{array}{l}\text { Diesel exhaust } \\
\text { (aqueous suspensions } \\
\text { and organic extracts) }\end{array}$ & Fibroblasts & SCE & Keane et al., 1991 \\
\hline $\begin{array}{l}\mathrm{PM} \\
\text { (Fine and coarse, } \\
\text { organic extracts) }\end{array}$ & Fibroblasts & Strand breaks (Comet) & Hsiao et al., 2000 \\
\hline $\begin{array}{l}\text { PM } \\
\text { (Aqueous suspensions) }\end{array}$ & Lung epithelial cells & Strand breaks (Comet) & Dellinger et al.. 2001 \\
\hline $\begin{array}{l}\text { PM. ROFA } \\
\text { (Aqueous suspensions) }\end{array}$ & Bronchial epithelial cells & 8-OHdG & Prahalad et al., 2001 \\
\hline $\begin{array}{l}\text { PM } \\
\text { (Fine and coarse, } \\
\text { organic extracts) }\end{array}$ & Bronchial epithelial cells & SCE & Hornberg et al., 1998 \\
\hline $\begin{array}{l}\text { PM } \\
\text { (organic extracts) }\end{array}$ & Bacteria (Ames test) & Mutations & Buschini et al., 2001 \\
\hline
\end{tabular}

ROFA (residual oil fly ashes), SCE (sister chromatide exchanges).

Metals, especially iron, which are abundantly present in particles such as coal fly ashes and PM, and also as (minor) impurities in quartz have been shown to play an important role in the ability of these particles to induce ROS (Donaldson et al., 1997: Van Maanen et al., 
1999). Consequently, this process has been recognised as a contributing factor in DNA damage caused by metal containing dusts. Regarding PM, it should be noted that the composition varies with the particle size fraction. As a consequence, it has been demonstrated that the ability of PM-extracts to induce direct genotoxicity was indeed related to the size fraction used (Hornberg et al., 1998; Bushini et al., 2001). An additional and potentially important mechanism of genotoxicity is contained in the observation that many environmental particles have the ability to increase the transport of surface-adsorbed carcinogens into the peripheral lung. This mechanism of particle-associated carcinogens (PACs) is considered to play an important role in the genotoxic effects caused by diesel exhaust and PM. One important group of genotoxic compounds regularly adsorbed onto such a particles are polycyclic aromatic hydrocarbons (PAH's). Using organic extractions of particles it has been indicated that these compounds play an important role in PM-mediated genotoxicity (Seemayer et al., 1994; Hornberg et al., 1998; Hsiao et al., 2000; Bushini et al., 2001). More specifically, the genotoxic and carcinogenic activity of PAH's can be attributed to the formation of DNA adducts by reactive PAH metabolites (Hall and Grover, 1990). However, the question raises whether adsorbed PAH's are really bioavailable in in vivo biological systems (Greim et al., 2001). With this respect, studies with diesel and carbon black have shown negative outcomes (Gallagher et al., 1994).

\subsection{Link between inflammation and carcinogenesis}

It is generally accepted that chronic inflammation is closely associated with a variety of malignancies (Weitzman and Gordon, 1990). These initial clinical observations have led to a plethora of studies investigating the possible mechanisms by which inflammation could be involved in tumour formation. The discovery in the $1960 \mathrm{~s}$ that inflammatory phagocytes generate large amounts of ROS has provided a plausible basis for the association of inflammation and carcinogenesis: ROS released by inflammatory cells might cause injury to target cells, thereby inducing a large number of processes possibly involved in tumour development (Figure 5).

\subsubsection{Genotoxic effects of inflammatory phagocytes}

Whereas ROS might be involved in various carcinogenic processes (Figure 5), numerous studies investigating the link between inflammation and carcinogenesis have focussed on ROS-induced genotoxic effects. As shown in Table 4, several genotoxic properties of inflammatory phagocyte-derived ROS/RNS have been investigated, including DNA damage, DNA mutations, and chromosomal abberations. The first observation of phagocyte-induced genotoxicity and the crucial role of ROS herein was described by Weitzman and Stossel in 1981, who found that the ability of peripheral blood leukocytes to induce mutations in bacteria was markedly attenuated when cells were used from a patient with chronic granulomatous disease (CGD). In CGD, neutrophils have a defect in the NADPH-oxidasemediated generation of $\mathrm{O}_{2}{ }^{*}$, and are thus unable to generate ROS. The first study on genotoxic effects in mammalian cells was published in 1983 by Weitberg et al., describing leukocyte-induced sister chromatide exchanges in hamster ovary cells. Further studies from Weitzman and Stossel (1984) on induction of mutations, ultimately led to a publication from the same group on the development of tumours in athymic mice injected with fibroblasts, which were previously exposed to activated human neutrophils (Weitzman et al., 1985). From then, mechanisms were further elucidated by the discovery of DNA base damage induced by neutrophils, first in naked DNA (Frenkel and Chrzan, 1987; Jackson et al., 1989), and later 
also in target cellular DNA (Dizdaroglu et al., 1993). At the same time neutrophils and macrophages were also found to induce target cellular DNA strand breakage (Schraufstätter et al., 1988; Chong et al., 1989). A further crucial study, especially with regard to particleinduced tumorigenesis, was from Driscoll et al. (1997a), who directly demonstrated that neutrophils, obtained by BAL of particle-exposed rats, were mutagenic to alveolar epithelial cells in vitro.

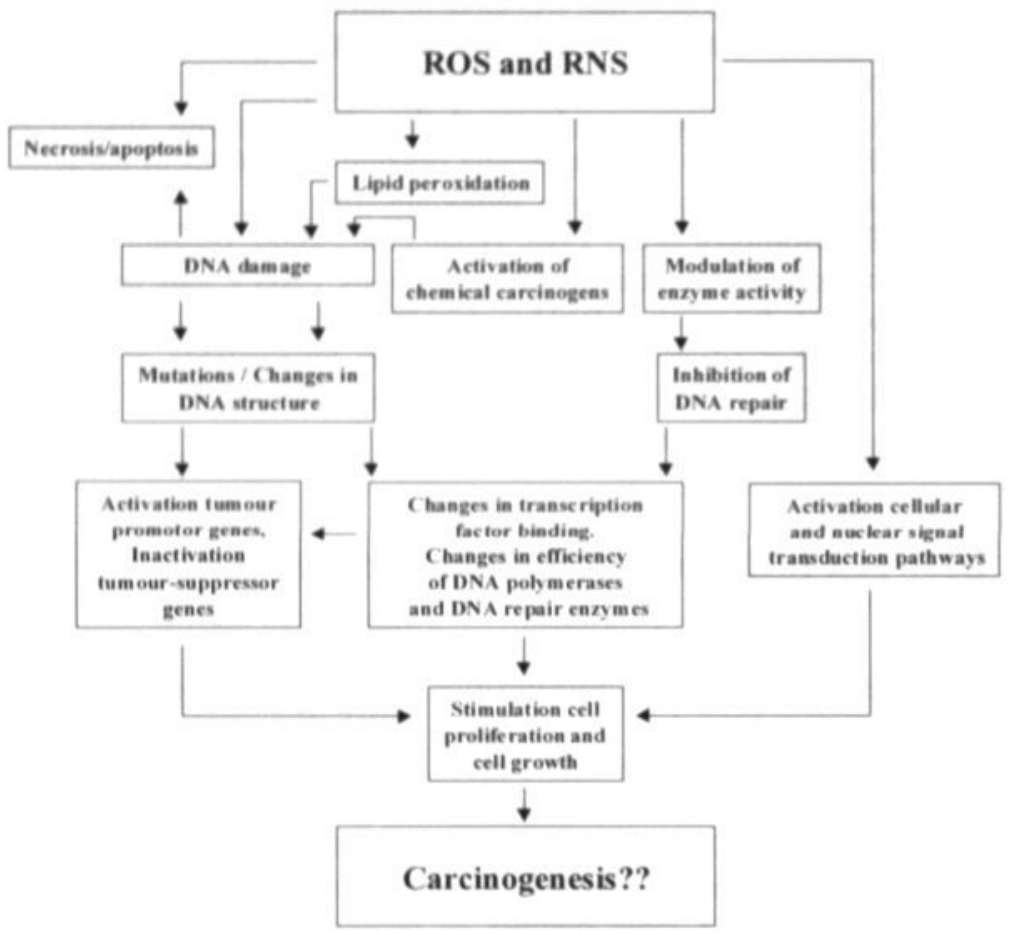

Figure 5. Some important ROS/RNS-mediated processes involved in carcinogenesis.

\section{Mechanisms}

The specific role of ROS in phagocyte-induced genotoxicity was initially confirmed using various specific antioxidants (Weitzman and Stossel, 1982; Weitberg et al., 1985). This approach, and more specifically, the use of catalase, has led to the discovery of hydrogen peroxide as the major ROS mediating genotoxic processes induced by activated phagocytes (Lewis and Adams, 1987; Schraufstätter et al., 1988; Shacter et al., 1988). Indeed, using various target cells in vitro, it was shown that hydrogen peroxide was able to induce base damage and strand breakage in nuclear DNA (Schraufstätter et al., 1988; McDonald et al., 1993; Spencer et al., 1995). Based on the specific DNA base modifications as detected in target cells exposed to reagent $\mathrm{H}_{2} \mathrm{O}_{2}$ or activated neutrophils, it is now hypothesised that $\mathrm{H}_{2} \mathrm{O}_{2}$ acts as a progenitor of the hydroxyl radical, which ultimately attacks DNA (Schraufstätter et al., 1988; Jackson et al., 1989; Dizdaroglu et al., 1993; Spencer et al., 1995). 
Table 4. Chronological overview of in vitro studies reporting genotoxic properties of inflammatory phagocytes.

\begin{tabular}{|c|c|c|c|}
\hline $\begin{array}{l}\text { Inflammatory } \\
\text { Phagocytes }\end{array}$ & Target & Genotoxic endpoint & Reference \\
\hline $\begin{array}{l}\text { Neutrophils } \\
\text { Monocytes }\end{array}$ & Salmonella & Mutations & Weitzman and Stossel, 1981 \\
\hline Neutrophils & Photobact. Fischeri & Mutations & Barak et al., 1983 \\
\hline Leukocytes & $\begin{array}{l}\text { Chinese hamster } \\
\text { ovary cells }\end{array}$ & Sister-chromatid exchanges & Weitberg et al., 1983 \\
\hline Macrophages & Salmonella & Mutations & Fulton et al., 1984 \\
\hline Neutrophils & $\begin{array}{l}\text { Chinese hamster } \\
\text { ovary cells }\end{array}$ & Mutations (HPRT) & Weitzman and Stossel, 1984 \\
\hline Neutrophils & Mouse fibroblasts & Malignant transformation & Weitzman et al., 1985 \\
\hline Macrophages & $\begin{array}{l}\text { Mouse mammary } \\
\text { tumour cell line }\end{array}$ & Mutations (HPRT) & Yamashina et al., 1986 \\
\hline Neutrophils & Naked DNA & $\begin{array}{l}\text { DNA base damage (thymidine } \\
\text { glycol, 5-hydroxymethyl-2'-deoxy- } \\
\text { uridine) }\end{array}$ & Frenkel and Chrzan, 1987 \\
\hline Neutrophils & E. Coli & Mutations & De Togni et al., 1988 \\
\hline $\begin{array}{l}\text { Neutroplasts } \\
\text { Neutrophils }\end{array}$ & Human lymphocytes & $\begin{array}{l}\text { Strand breaks and poly-ADP-ribose } \\
\text { polymerase activity }\end{array}$ & Schraufstätter et al., 1988 \\
\hline Neutrophils & $\begin{array}{l}\text { Plasmacytoma cell } \\
\text { line }\end{array}$ & DNA strand breaks & Shacter et al., 1988 \\
\hline Macrophages & $\begin{array}{l}\text { Mouse mammary } \\
\text { tumor cell line }\end{array}$ & DNA strand breaks & Chong et al., 1989 \\
\hline Neutrophils & Naked DNA & DNA base modifications & Jackson et al., 1989 \\
\hline Neutrophils & Tumour cells & DNA strand breaks & Shacter et al., 1990 \\
\hline Neutrophils & Human Ad293 cells & DNA base modifications & Dizdaroglu et al., 1993 \\
\hline Neutrophils & $\begin{array}{l}\text { Mononuclear } \\
\text { leukocytes }\end{array}$ & DNA strand breaks & Van Staden et al.. 1993 \\
\hline Neutrophils & Human Ad293 cells & Mutations (frequency and spectrum) & Akman et al., 1996 \\
\hline $\begin{array}{l}\text { Neutrophils } \\
\text { Macrophages }\end{array}$ & $\begin{array}{l}\text { Alveolar epithelial } \\
\text { cells }\end{array}$ & Mutations (HPRT gene) & Driscoll et al., 1997a \\
\hline Neutrophils & Naked DNA & 8-nitrodG & Byun et al., 1999 \\
\hline $\begin{array}{l}\text { Neutrophils } \\
\text { Eosinophils }\end{array}$ & Naked DNA & 8-OHdG & Shen et al., 2000 \\
\hline
\end{tabular}


However, it is important to note that also other possible mechanisms of phagocyteinduced genotoxicity have been proposed. For instance, Lewis and Adams (1987), found that macrophages, releasing both $\mathrm{H}_{2} \mathrm{O}_{2}$ and metabolites of arachidonic acid were more efficient in inducing DNA damage than cells that only released $\mathrm{H}_{2} \mathrm{O}_{2}$. Alternatively, Gera and Lichtenstein (1991) demonstrated that neutrophil-derived defensins were able to induce DNA strand breaks in target cells. The possible role of neutrophil-derived products, other than $\mathrm{H}_{2} \mathrm{O}_{2}$, is further illustrated by the observation that the mutational spectrum induced by activated neutrophils was different from that induced by reagent $\mathrm{H}_{2} \mathrm{O}_{2}$ (Akman et al., 1996). Another important mechanism by which neutrophils can contribute to genotoxicity effect is their ability to activate polycyclic aromatic hydrocarbons (PAH's) to a DNA binding metabolite (Trush et al., 1985; Kensler et al., 1987). For instance, using the same in vitro model as will be described in Chapter 5, we demonstrated that activated neutrophils amplified the formation of DNA adducts by benzo[a]pyrene in epithelial lung target cells (Borm et al., 1997). In such manner the genotoxic hazard of inhaled particle-associated PAH's could be enhanced due to a concomitant inflammatory reaction.

\subsubsection{Neutrophilic inflammation in relation to particle-induced genotoxicity and carcinogenicity in the rat}

The rat has been identified as a sensitive species with regard to particle-induced lung tumour formation. In these animals it was shown that chemical and physical differences between various particles may not be significant factors in the lung tumour response, since patterns of tumour formation were not associated with any inherent genotoxic activity of the particles (Driscoll et al., 1996b). This suggests that there must be a common mechanism by which both toxic (e.g. quartz, diesel soot) and non-toxic particles (e.g. titanium dioxide, carbon black) induce carcinogenesis in rats. In considering such a common mechanism it is currently hypothesised that at high particle doses, the inflammatory cell influx into the lung is accompanied by an activation of these cells to release enormous amounts of inflammatory mediators, which overwhelm the regular pulmonary anti-inflammatory defence systems (Greim et al., 2001). Especially the constant release of ROS by activated inflammatory cells is thought to be a crucial event, since ROS may cause genotoxic effects in the lung epithelium (Weitzman and Gordon, 1990). These genetic alterations, together with an increased target cell proliferation are now considered to be crucial components in the particle-induced carcinogenic response of the rat lung (Dungworth et al., 1994; Driscoll et al., 1996b; Borm and Driscoll, 1996: IARC 1997; Greim et al., 2001). Thus, the inflammatory response as observed in the rat provides a mechanism by which exposure to non-genotoxic particles can cause genotoxicity in lung target cells. Importantly, such a mechanism of secondary genotoxicity implies that genotoxicity and related carcinogenicity may not occur at exposure concentrations that do not induce inflammation. Therefore, it is suggested that in rats a threshold of particle-induced carcinogenicity may exist. This means that tumour formation is only found at particle doses eliciting a certain minimal level of phagocyte influx with associated ROS release at levels that overwhelm pulmonary antioxidant- and DNA repair protection systems (Figure 6) (Borm and Driscoll, 1996; Driscoll, 1996b).

\section{Role of neutrophils}

The inflammatory response in a particle-exposed rat is specifically characterised by an influx of neutrophils into the lung. For instance, in addition to an overall increase in inflammatory cells found in the BAL-fluid, the percentage of neutrophils has been reported to increase from $3-4 \%$, in healthy non-exposed rats, up to levels above $50 \%$ after subchronic exposure to particles such as quartz, carbon black or titanium dioxide. (Driscoll 1996a: Driscoll, 1997a; Albrecht et al., 2002: Duffin et al., 2001; Höhr et al., 2002). Regarding a role of neutrophils in 
particle-induced carcinogenesis, it has been shown that in vivo mutagenicity in alveolar type II cells, isolated after particle exposure, was paralleled by a neutrophilic inflammation (Driscoll et al., 1996a; Driscoll et al., 1997a). In these studies, brochoalveolar lavage is used to assess neutrophil influx into the lung. However, recent studies also found a relation between lung tumour rates and interstitial neutrophils in rats exposed to high doses of particles (Borm et al., 2000).

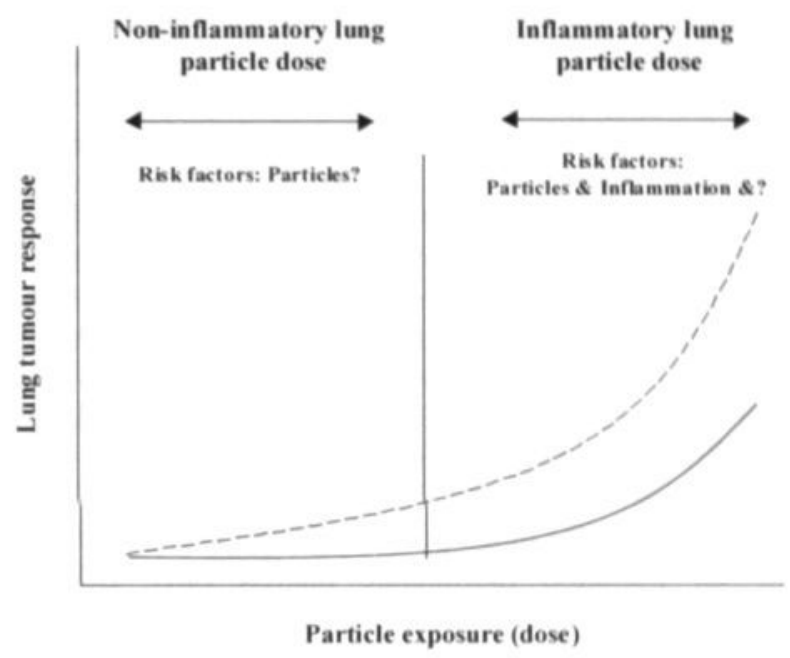

Figure 6. Hypothetical relationship between lung particle dose and tumour response in rats. Dotted line = hypothetical dose response for a particle that exhibits some inherent carcinogenic activity. Solid line = hypothetical dose response for a particle that is not inherent carcinogenic. At low doses the slope of the curve will be dependent on the inherent carcinogenic activity of the particles. If a particle does not possess any inherent carcinogenic activity (as indicated by genotoxicity data), the slope at non-inflammatory doses will be zero and a threshold will exist (solid line). At high, inflammatory doses, the lung tumour response will be dependent on (genotoxic) effects of both particles and inflammatory cell derived oxidants and possible other factors, such as increased cell proliferation. (Adapted from Driscoll. 1996b).

A further confirmation of the neutrophils' role was obtained by the observation that BAL-derived neutrophils from quartz-exposed rats were mutagenic (HPRT) to alveolar type II cells in vitro, whereas no direct effect of quartz was found in the same system. Notably, these in vitro effects of neutrophils were attenuated by the use of catalase, indicating the role of neutrophil-derived $\mathrm{H}_{2} \mathrm{O}_{2}$ (Driscoll et al., 1997a). In these studies, the capacity of alveolar macrophages to induce ex vivo mutagenesis was found to be significantly lower than that of neutrophils, which is in line with observations describing an increased ROS generating capacity of neutrophils compared to macrophages or monocytes (Kamp et al. 1994, Haugen et al., 1999, Prahalad et al., 1999). Further indications that neutrophils are indeed involved in early stages of particle-induced carcinogenicity are found in studies showing that levels of 8$\mathrm{OHdG}$ in lungs of quartz-exposed rats were associated with the intensity of neutrophil influx (Yamano et al., 1995; Nehls et al., 1997; Seiler et al., 2001). 


\subsection{Aim and outline of the thesis}

The mechanisms involved in particle-induced lung carcinogenesis seem complex and remain largely to be elucidated. The concept of a common inflammation-driven mechanism involving genotoxic processes and increased cell proliferation is mainly based on observations in rats, whereas its role in other rodents, or humans is much less clear. Nevertheless, the ability of particles to induce an inflammatory response hampers mechanistic research on particleinduced genotoxicity and necessitates the discrimination between primary (direct particleinduced) versus secondary (inflammation-induced) genotoxicity (Figure 7). However, there is convincing evidence indicating a crucial role of ROS in primary as well as secondary particleinduced genotoxic processes. Therefore, the central aim of the present thesis was to investigate mechanisms of ROS-induced DNA damage in lung target cells after particle exposure, and to elucidate the specific role of neutrophils herein. In the studies described in this thesis we primarily focussed on epithelial cells lining the respiratory tract, since these are considered to be a specific target for particle-induced carcinogenesis. Both in vivo and in vitro models were used. However, since current in vivo models are not well suited to distinguish between primary and secondary particle-induced genotoxic effects, the in vitro models were applied to sort out specific mechanisms involved in either direct particle-induced or neutrophil-induced DNA damage.

Two different particles are used in the present studies: I) crystalline silica (quartz) and II) ambient particulate air pollution (particulate matter, PM). Based on culminating epidemiological and (animal) experimental evidence, crystalline silica was recently classified as a human lung carcinogen (Group 1) by the International Agency for Research on Cancer (IARC, 1997). Alternatively, recent epidemiological studies on effects of long-term exposure to PM, evaluating data of about 500,000 people, indicated that each $10 \mu \mathrm{g} / \mathrm{m}^{3}$ elevation in fine particulate air pollution was associated with an approximate $8 \%$ increased risk of lung cancer mortality (Pope et al., 2002). However, although such data indicate that both particles have a considerable impact on human carcinogenesis, the mechanisms of their action are still unclear.

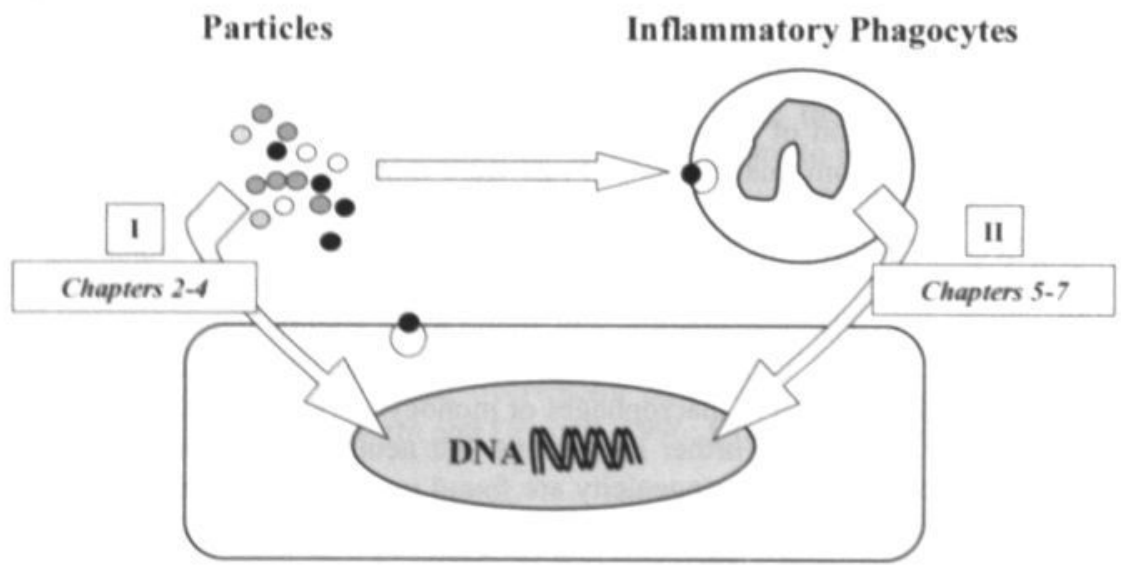

Lung epithelium

Figure 7. Schematic overview of the thesis. Particles can either directly (via I. 'primary genotoxicity'), or indirectly (via II. 'secondary genotoxicity') induce DNA damage in lung epithelial target cells. The different pathways and mechanism involved are discussed in the respective chapters as indicated in the figure 


\section{Quartz}

Silicon is one of the most abundant chemical elements in the earth's crust, accounting for about $30 \%$ of its total mass. Silica (chemical name: silicon dioxide), can exist in two major forms: a crystalline and an amorphous form. The overwhelming majority of natural crystalline silica exist as $\alpha$-quartz. It is abundant in most rock types, sands and soils. In the studies described in the present thesis, DQ12 quartz was used as it is a highly reactive quartz. Its particle size is $<5 \mu \mathrm{m}$ and it contains $87 \%$ crystalline silica, the remainder being mainly amorphous silica. DQ12 has been described and provided by Robock et al. (1973), and has been ground from a geological source in Dörentrup, Germany. Silicon-oxygen tetrahedra $\left(\mathrm{SiO}_{4}\right)$ are the basic units of crystalline silica, in which the 3-dimensional framework is determined by regular arrangement of the tetrahedra. Silica is rather poorly soluble in water, which is especially true for the crystalline form. Quartz is a major component of soils, composing about $90 \%$ of all sand fractions in a soil. Most silica in commercial use is obtained from natural occurring sources. Silica sand has been used for many different purposes, such as in the manufacturing of glass. Quartz crystals, such as can be found in mines in Brazil, are used in electronic and optical industries.

Because of the extensive natural occurrence of crystalline silica and its wide use, workers may be exposed to crystalline silica in a large number of industries (e.g. mines, foundries, cement and glass industries) and occupations (e.g. constructors, sand blasters, farmers). The severity of its health effects and the widespread nature of exposure have been recognised for a long time. In subjects chronically exposed to silica, silicosis may develop, which may develop into progressive massive fibrosis. Additionally, many other nonneoplastic pulmonary effects have been observed in humans exposed to crystalline silica, including inflammation, emphysema, and airway obstruction (IARC, 1997). Moreover, epidemiological and animal studies have led to the classification of crystalline silica from occupational sources as a human lung carcinogen (Group I) by the International Agency for Research on Cancer (IARC, 1997). Importantly however, in their overall evaluation the Working group noted that "carcinogenicity in humans was not detected in all industrial circumstances studied". Therefore, it was stated that "carcinogenicity of crystalline silica was dependent on its inherent characteristics and on factors affecting its ultimate biological activity".

\section{Particulate matter}

Ambient particulate air pollution, generally described as particulate matter (PM) is a complex mixture of solid particles and liquid droplets that may vary in mass, size and composition, depending on sources and weather conditions. With respect to size, PM can be divided into three fractions (See also Chapter 1.1.1). The 'coarse' fraction represents the large inhalable particles ranging from 1 to $10 \mu \mathrm{m}$ and generally consists of particles mainly derived from soil and other material from mechanical processes, such as drilling, crushing and grinding. The 'fine' particle fractions $(0.1-2.5 \mu \mathrm{m})$ contains a mixture of particles including carbonaceous material, like soot (with adsorbed compounds such as metals and organic compounds), acid condensates and nitrate particles. This fraction is mainly derived from fossil fuel combustion (automobile engines, power plants, industry). The 'ultrafine' fraction $(0.001-0.1 \mu \mathrm{m})$ is primarily derived from automobile engine exhaust (diesel and otto types). PM is comprised, in terms of particle numbers by a large part of ultrafines. Using rats it has been well demonstrated that per given mass, ultrafine particles are more toxic than fine particles, mainly due to their capacity to elicit a greater inflammatory response (Oberdörster, 2001). Moreover, the high reactivity of the ultrafine PM fraction could also be attributed to the large surface area provided by these particles, which allows large amounts of environmentally substances and pollutants to be adsorbed to the particle surface. In that way the (ultrafine) carbon particle 
core of PM may act as a 'carrier' of carcinogens and other (soluble) toxic compounds, including polycyclic aromatic hydrocarbons, metals, sulfates, nitrates, endotoxins, pollen fragments, and acids.

Numerous epidemiological studies have shown a statistical association between elevations in ambient levels of particulate matter (PM) and increased morbidity and mortality among the general population. For instance, inhalation of (fine) PM at elevated levels has been associated with increased asthmatic episodes, increased hospital admissions due to respiratory problems, increased prevalence of bronchitis and emphysema, and increased mortality due to cardiopulmonary diseases (Dockery et al., 1993; Schwartz et al., 1999; Peters et al., 2000, Pope et al., 2002). Especially the relation between PM exposure and acute cardiovascular disease is intriguing and various groups started working to set out the biological mechanism of this effect. For instance, in studies not further described in the present thesis we described an acute effect of PM on the contractability of rat aortic rings (Knaapen et al., 2001), whereas others focussed on effects of PM on atherosclerosis, blood coagulability and autonomic nervous control of the heart (Seaton et al., 1995; Godleski et al., 2000; Suwa et al., 2002). In addition to these more or less acute effects, PM exposure has also been related to chronic effects including cancer (Cohen and Pope, 1995; Pope et al., 2002). Until now, research on possible carcinogenic effects of PM was mainly focussed on the (in vitro) genotoxicity of adsorbed organic components. However, no chronic (animal) studies have yet been performed to study the carcinogenic effects of PM more closely. As a consequence, the mechanisms of PM-induced carcinogenicity remain unclear. Anyhow, due to its close relation with mortality and morbidity, in Europe the Air Quality Limit Values have been proposed. Because only particles with a size smaller than $10 \mu \mathrm{m}$ are considered to be inhalable, these standards apply to the mass concentrations of particles with aerodynamic diameters lower than and $10 \mu \mathrm{m}\left(\mathrm{PM}_{10}\right)$. In Europe, the annual mean limit value for $\mathrm{PM}_{10}$ is currently as low as $40 \mu \mathrm{g} / \mathrm{m}^{3}$.

Notably, from the descriptions above it can be concluded that quartz and PM are totally different types of particles. Adverse health effects induced by quartz exposure are mainly associated with occupational settings. PM-related disease on the other hand, is a typical environmental problem, since the associations between PM exposure and disease are observed even after controlling for smoking, occupational exposure and various other (individual) risk factors. Furthermore, it should be noted that possible carcinogenic effects represent only a small part of the large number of different adverse healh effects associated with both PM and quartz exposure.

\subsubsection{Outline of the Thesis}

In the Chapters 2-4 the capacity and mechanism of both PM and quartz to induce direct, inflammatory cell-independent DNA damage in epithelial lung cells in vitro is described. Moreover, in these chapters the capacity of both particles to induce DNA damage will be related to their respective (acellular) ROS-generating properties. Special emphasis is put on the role of transition metals and particle surface reactivity.

In rats, it has been demonstrated that neutrophils were more potent to induce ROSmediated mutagenicity in epithelial lung cells than macrophages (Driscoll et al., 1997a). This is in line with data showing that the amount of ROS released by neutrophils upon stimulation with various soluble and particulate stimuli, including phorbol esters, PM and asbestos, largely exceeds that of macrophages and monocytes (Kamp et al. 1994. Haugen et al., 1999, Prahalad et al., 1999). Together with the fact that neutrophils represent about $50 \%$ of the inflammatory cells found in bronchoalveolar lavage after high doses of particles, their 
extensive ROS-generating capacity obviously makes them the major effector cell in secondary genotoxic processes in the rat.

In Chapter 5 and 6 studies investigating the ability and mechanism of neutrophils to induce DNA damage in lung epithelial cells are described. Therefore, a coincubation model of neutrophils and rat type II epithelial cells was developed (Chapter 5). Moreover, to extend our in vitro observations in vivo, the nose is applied as an easily accessible part of the respiratory tract to investigate neutrophil-related DNA damage in human respiratory tract epithelial cells (Chapter 6).

In Chapter 7 the interplay of particles and inflammatory cells in the induction of epithelial DNA damage is studied in rats intratracheally instilled with crystalline silica (quartz). Moreover, the role of the reactive particle surface of quartz is assessed using specific surface coatings. Finally, in Chapter 8 the findings are summarised and put in a general perspective on particle genotoxicity.

\section{References}

Adler KB, Holden-Stauffer WJ, Repine JE. Oxygen metabolites stimulate release of high-molecular-weight glycoconjugates by cell and organ cultures of rodent respiratory epithelium via an arachidonic acid-dependent mechanism. J Clin Imvest 85: 75-85, 1990.

Akman SA, Sander F, Garbutt K. In vivo mutagenesis of the reporter plasmid pSP189 induced by exposure of host Ad293 cells to activated polymorphonuclear leukocytes. Carcinogenesis 17:2137-2141, 1996.

Alavanja MC, Brownson RC, Boice JD jr, Hock E. Pre-existing lung disease and lung cancer among nonsmoking women. Am J Epidemiol 136: 623-632, 1992.

Albrecht C. Adolf B, Weishaupt C, Hǒhr D, Zeitträger I. Friemann J, Borm PJA. Clara-cell hyperplasia after quartz and coaldust instillation in rat lung. Inhal Toxicol 13: 191-205, 2001.

Albrecht C, Becker A, Schins RPF, Hōhr D, Unfried K, Knaapen AM, Borm PJA. Importance of surface characteristics of DQ12 quartz for acute inflammation. Ann Occup Hyg 2002, in press.

Althaus FR, Lawrence SD, Sattler GI. Pitot HC. ADP-ribosyltransferase activity in cultured hepatocytes: interactions with DNA repair. J Biol Chem 257: 5528-5535, 1982.

Ames BN. Endogenous oxidative DNA damage, ageing, and cancer. Free Radic Res Commun 7: 121-128, 1989.

Arroyo CM. Carmichael AJ, Bouscarel B. Liang JH, Weglicki WB. Endothelial cells as a source of oxygen-free radicals. An ERS study. Free Radic Res Commun 9: 287-296, 1990.

Aruoma OI. Halliwell B. Gajewski E. Dizdaroglu M. Copper ion dependent damage to bases in DNA in the presence of hydrogen peroxide. Biochem J 273, 601-604, 1991.

Askling J. Grunewald J. Eklund A. Hillerdal G. Ekbom A. Increased risk for cancer following sarcoidosis. Am J Respir Crit Care Med 160: 1668-1672, 1999.

Babior BM. Kipnes RS, Curnutte JT. Biological defence mechanisms: the production by leukocytes of superoxide, a potential bactericidal agent. J Clin Invest 52: 741-744, 1973.

Babior BM. The respiratory burst oxidase. Hematology Oncology clinics of North America 2: 201-212, 1988.

Babior BM Phagocytes and oxidative stress. Am J Med 109: 33-44, 2000.

Baldridge CW, Gerard RW. The extra respiration of phagocytosis. Am J Physiol 103:235, 1933.

Barak M, Ulitzur S, Merzbach D. Phagocytosis-induced mutagenesis in bacteria. Mutat Res 121: 7.16, 1983.

Barnes PJ. Reactive oxygen species and airway inflammation. Free Radic Biol Med 9:235-243. 1990.

Bashir S. Harris G. Denman MA. Blake DR, Winyard PG. Oxidative DNA damage and cellular sensitivity to oxidative stress in human autoimmune diseases. Ann Rheum Dis 52: 659-666, 1993.

Basu AK. Marnett I.J. Unequivocal demonstration that malondialdehyde is a mutagen. Carcinogenesis 4, 331-333. 1983.

Becker S, Soukup JM, Gilmour MI, Devlin RB. Stimulation of human and rat alveolar macrophages by urban air particulates: effects on oxidant radical generation and cytokine production. Toxicol Appl Pharmacol 141: 637-648, 1996.

Beckman JS, Beckman TW. Chen J. Marshall PA. Freeman BE. Apparent hydroxyl radical production by peroxynitrite: implications for endothelial injury from nitric oxide and superoxide. Proc Natl Acad USA 87: 1620-1624, 1990.

Berg I. Schluter T. Gercken G. Increase of bovine alveolar macrophage superoxide anion and hydrogen peroxide release by dusts of different origin. J Toxicol Emiron Health 39:341-354, 1993.

Boiteux S, Radicella JP. Base excision repair of 8-hydroxyguanine protects DNA from endogenous oxidative stress. Biochem 81: 59-67, 1999

Bolann BJ. Ulvik RJ. On the limited ability of superoxide to release iron from ferritin. Eur $J$ Biochem 193: 899-904, 1990.

Borm PJA. Driscoll KE. Particles, inflammation and respiratory tract carcinogenesis. Toxicol Letl 88: 109-113. 1996.

Borm PJA. Knaapen AM, Schins RPF, Godschalk RWI. Van Schooten FJ. Neutrophils amplify the formation of DNAadducts by benzolajpyrene in lung target cells. Emiron Health Perspect 105 (suppl. 5), 1089-1093, 1997.

Borm PJA. Hōhr D. Steinfartz Y, Zeittrăger I. Albrecht C. Chronic inflammation and tumor formation in rats after intratracheal instillation of high doses of coal dusts, titanium dioxides and quart. Inhal Toxicol 12 (suppl 3), 225-231. 2000 
Bradley MO, Kohn KW, X-ray-induced DNA double strand break formation and repair in mammalian cells as measured by neutral filter elution. Nucleic Acids Res 7: 793-804, 1979.

Brown DM, Wilson MR, MacNee W. Stone V, Donaldson K. Size-dependent proinflammatory effects of ultrafine polystyrene particles: a role for surface area and oxidative stress in the enhanced activity of ultrafines. Toxicol Appl Pharmacol 175: 191-9, 2001.

Burney S, Caulfield J., Niles JC, Wishnok JS, Tannenbaum SR. The chemistry of DNA damage from nitric oxide and peroxynitrite. Mutat Res 424: 37-49, 1999.

Buschini A. Cassoni F, Anceschi E, Pasini L. Poli P, Rossi C. Urban airborne particulate: genotoxicity evaluation of different size fractions by mutagenesis tests on micro-organisms and comet assay. Chemosphere 44: 1723-1736, 2001.

Byun J, Henderson JP, Mueller DM, Heinecke JW. 8-Nitro-2'-deoxyguanosine, a specific marker for oxidation by reactive nitrogen species, is generated by the myeloperoxidase-hydrogen peroxide-nitrite system of activated human phagocytes. Biochemistry 38: 2590-2600, 1999.

Carswell EA, Old I.J, Kassel RI., Green S, Fiore N, Williamson B. An endotoxin-induced serum factor that causes necrosis of tumors. Proc Natl Acad Sci US A. 72: 3666-3670, 1975.

Carter JD, Ghio AJ, Samet JM, Devlin RB. Cytokine production by human airway epithelial cells after exposure to an air pollution particle is metal dependent. Toxicol Appl Pharmacol 146: 180-188, 1997.

Carter JD, Driscoll KE. The role of inflammation, oxidative stress, and proliferation in silica-induced lung disease: a species comparison. J Env Pathol Toxicol Oncol 20 (suppl 1): 33-43, 2001

Castranova V. Huffman L.J. Judy DJ, Bylander JE Lapp LN, Weber SI. Blackford JA. Dey RD. Enhancement of nitric oxide production by pulmonary cells following silica exposure. Emviron Health Perspect 106 (suppl 5): 1165-1169. 1998.

Catheart R. Schwiers F. Saul RI., Ames BN. Thymine glycol and thymidine glycol in human and rat urine: a possible assay for oxidative DNA damage. Proc Natl Acad Sci U S A 81: 5633-5637, 1984.

Cheng KC, Cahill DS, Kasai H, Nishimura S, Locb L.A. 8-Hydroxyguanine, an abundant form of oxidative DNA damage, causes $G->$ T and $A-C$ substitutions. J Biol Chem 267; 166-172, 1992

Chong YC, Heppner GH, Paul LA. Fulton AM. Macrophage-mediated induction of DNA strand breaks in target tumor cells. Cancer Res 49: 6652-6657, 1989.

Churg $A$. The uptake of mineral particles by pulmonary epithelial cells. Am J Respir Crit Care Med 154: 1124-1140, 1996.

CIIT final report. Subchronic inhalation toxicity study of pigmentary titanium dioxide in female B6CFI mice. Fischer 344 rats, and Syrian Golden Hamsters. Chemical Industry Institute of Toxicology, Research Triangle Park, NC, USA. 2001.

Cohen AJ, Pope CA III: Lung cancer and air pollution. Environ Health Perspect 103 (suppl 8): 219-224, 1995.

Collins RH, Feldman M. Fordtran JS. Colon cancer, dysplasia and surveillance in patients with ulcerative colitis: A critical review. N Engl J Med 316: 1654-1658, 1987.

Collins AR, Duthie SJ, Dobson VL. Direct enrymatic detection of endogenous oxidative base damage in human lymphocyte IDN Carcinogenesis 14:1733-1735, 1993.

Clarke SW, Yeates D. Deposition and clearance. In: (Murray JF and Nadel JA, eds) Textbook of respiratory medicine. Second edition, 1994, WB Saunders company, Philadelphia, USA.

Cruickshank AH, McConnel EM, Miller DG. Malignancy in scars, chronic ulcers and sinuses. J Clin Pathol 16:573-580, 1963

Daniel I.N, Mao Y, Saffiotti U, Oxidative DNA damage by crystalline silica. Free Radic Biol Med 14:463-472, 1993.

Daniel I N, Mao Y. Williams AO. Saffiotti U. Direct interaction between crystalline silica and DNA - a proposed model for silica carcinogenesis. Scramd J Work Emviron Health 21 (suppl 2): 22-26, 1995.

Dellinger B. Pryor WA, Cueto R, Squadrito GI. Hegde V, Deutsch WA. Role of free radicals in the toxicity of airborne fine particulate matter. Chem Res Toxicol 14: 1371-1377, 2001

De Togni P. Fox HB, Morrissey S, Tansey I.R, Levy SB, Bavior BM. Plasmids in bacteria exposed to activated neutrophils mediate mutagenesis when transferred to new hosts. Blood 71: 463-466, 1988

Diociaiuti M. Balduzzi M. De Berardis B. Cattani G, Stacchini G, Ziemacki G, Marconi A. Paoletti L. The two PM(2.5) (fine) and PM(2.5-10) (coarse) fractions: evidence of different biological activity. Environ Res 2001 86: 254-262, 2001.

Dizdaroglu M, Olinski R, Doroshow JH. Akman SA. Modification of DNA bases in chromatin of intact target human cells by activated human polymorphonuclear leukocytes. Cancer Res 53; 1269-1272, 1993.

Djeu JY, Serbousch D, Blanchard DK. Release of tumor necrosis factor by human polymorphonuclear leukocytes. Blood 76 : $1405-1409,1090 \mathrm{a}$.

Djeu JY. Matsushima K. Oppenheim J. Shiotsuki K. Blanchard DK. Functional activation of human neutrophils by recombinant monocyte-derived neutrophil chemotactic factor II. $8 . J$ Immanol $144: 2205-2210,1990 \mathrm{~b}$

Docken DW, Pope CA III. Xu X, Spengler JD. Ware JH. Fay ME, Ferris BG. Speizer FE: An association between air pollution and mortality in six IIS. cities. New Fing J Medicine 329: 1753-1759, 1993

Doclman CJ. Bast A. Orygen radicals in lung pathology. Fre Rodic Biol Med 9: 381-400, 1990.

Doerschuk CM. Allard, MF, Martin BA. MacKenzic A. Hogg JC. Marginated pool of neutrophils in lungs of rabbits. $J$ App Phavel 63: 1806-1815, 1987.

Don Porto Carero A. Hoet PHM. Verschaeve 1. Schoeters G, Nemery B. Genotoxic effects of carton black particles, diesel cxhaust particles, and urban air particulates and their extracts on a human alveolar epithelial cell line (A.549) and a human monocytic cell line (THP-1). Emiron Mol Mfutaven 37: 155-163, 2001

Donaldson K, Brown DM. Mitchell C. Dineva M. Beswick PH, Gilmour P. MacNee W. Free radical activity of PM mediated generation of hydroxyl radicals. Emvinon Hoalth Peryect 105 (suppl 5): 1285-1280, 1997.

Donaldson K. Stone V. Duffin R. Clouter A, Schins RPF. Borm PJA. The quart hazard: effects of surface and matrix on inflammogenic activity. J Eminon Pathol Toxisw Omool 20 (Suppl 1): 109-18. 2001

Donaldson K. Tran Cl. Inflammation caused by particles and fiters. Inhal Toxhod 14:5-27, 2002 
Dong HY, Buard A, Levy F, Renier A, Laval F, Jaurand MC. Synthesis of poly(ADP-ribose) in asbestos treated rat pleural mesothelial cells in culture. Mutat Res 331: 197-204. 1995.

Driscoll KE, Higgins JM, Leytart MJ, Crosby L. Differential effects of mineral dusts on the in vitro activation of alveolar macrophage eicosanoid and cytokine release. Toxicol In Vitro 4: 284-288, 1990.

Driscoll KE, Maurer JK, Hassenbein DG, Carter JM, Janssen YMW, Mossman BT, Osier M, Oberdörster G. Contribution of macrophage-derived cytokines and cytokine networks to mineral dust-induced lung inflammation. In: Dungworth D. Mohr U. Mauderly J, Oberdörster G (eds). Toxic and carcinogenic effects of solid particles in the respinafory tract. Washington, ILSI press, 177-190, 1994 a.

Driscoll KE. Macrophage inflammatory proteins: biology and role in pulmonary inflammation. Exp Lung Res 20: 473-490, $1994 \mathrm{~b}$.

Driscoll KE, Carter JM, Howard BW. Hassenbein DG, Pepelko W. Baggs, RB, Oberdörster G. Pulmonary inflammatory, chemokine, and mutagenic responses in rats after subchronic inhalation of carbon black. Toxicol Appl Pharmacol. 136: 372-80, 1996a.

Driscoll KE. Role of inflammation in the development of rat lung tumors in response to chronic particle exposure. Inhal Toxicol 8 (suppl): 139-153, 1996b.

Driscoll KE, Carter JM. Hassenbein DG, Howard B. Cytokines and particle-induced inflammatory cell recruitment. Environ Health Persp 105 (suppl 5): 1159-1164, 1997

Driscoll KE, Deyo LC, Carter JM. Howard BW. Hassenbein DG, Bertram TA. Effects of particle exposure and particleelicited inflammatory cells on mutation in rat alveolar epithelial cells. Carcinogenesis 18: 423-430, 1997a.

Driscoll KE, Howard BW. Carter JM. Janssen YM. Mossman BT. Isfort RJ. Mitochondrial-derived oxidants and quart/ activation of chemokine gene expression. Adv Exp Mcd Biol 500; 489-496, 2001

Driscoll KE, Carter JM, Borm PJA. Antioxidant defense mechanisms and the toxicity of fibrous and nonfibrous particles. Inhal Toxicol 14: 101-118, 2002

Drost E, MacNee W. Potential role of IL -8, platelet-activating factor and TNF-a in the sequestration of neutrophils in the lung: effects on neutrophil deformability, adhesion receptor expression, and chemotaxis. Eur $J$ Immunol 32: 393-403, 2002.

Dubois CM, Bissonnette E, Rola-Pleszczynski M. Asbestos fibers and silica particles stimulate rat alveolar macrophages to release tumor necrosis factor. Am Rv Repir Dis 139: 1257-1264, 1989.

Duffin R, Gilmour PS, Schins RPF, Clouter A, Guy K. Brown DM, MacNee W. Borm PJA, Donaldson K. Stone V. Aluminium lactate treatment of DQ12 quartz inhibits its ability to cause inflammation, chemokine expression and NFkappaB activation. Toxicol Appl Pharmacol 176: 10-17, 2001.

Dunford R, Salinaro A, Cai L. Serpone N. Horikoshi S, Hidaka H, Knowland J. Chemical oxidation and DNA damage catalised by inorganic sunscreen ingredients. FEBS Lett 418: 87-90, 1997

Dungworth Di., Mohr U. Heinrich H. Emst H. Kittel B. Pathologic effects of inhaled particles in rat lungs: associations between inflammatory and neoplastic processs. In Mohr U (eds): Toxic and carcinogenic effects of solid particles in the respiratory tract. Washington: II.SI press, pp 75-98, 1994.

Eastman A. Barry MA. The origins of DNA breaks: A consequence of DNA damage, DNA repair, or apoptosis?. Cancer Invest 10: 229-240, 1992.

Elias JA, Freundlich B, Kern JA, Rosenboom J. Cytokine networks in the regulation of inflammation and fibrosis in the lung. Chest 97: 1439-1454, 1990.

Elias 7. Poirot O, Daniere MC. Terzetti F, Marande AM. Dzwigaj S. Pezerat H. Fenoglio I. Fubini B. Cytotoxic and transforming effects of silica particles with different surface properties in syrian hamster (SHE) embryo cells. Toxicol In Vitro 14: 409.422, 2000

Fenton HJH. Oxidation of tartaric acid in the presence of iron. J Chem Soc 899-910, 1894

Floyd RA, Watson JJ. Wong PK. Altmiller DH. Rickard RC. Hydroxyl free radical adduct of deoxyguanosine: sensitive detection and mechanisms of formation. Free Rad Res Commun 1: 163-172, 1986.

Floyd RA. The role of 8-hydroxyguanine in carcinogenesis. Carcinogenesis 11: 1447-1450, 1990.

Foster WM. Deposition and clearance of inhaled particles. In: Holgate ST, Samet JM. Koren HS, Maynard RI. eds.) Air pollution and health. Academic press, 1999, San Diego, UAS.

Frenkel K. Chrzan K. Hydrogen peroxide formation and DNA base modification by tumor promotor-activated polymorphonuclear leukocytes. Carcinogenesis 8: 455-460, 1987.

Fubini B, Giamello E. Volante M. Bolis V. Chemical functionalities at the silica surface determining its reactivity when inhaled. Formation and reactivity of surface radicals. Toxicol Ind Health 6:571-598, 1990

Fubini B. Surface chemistry and quartz hazard. Ann Occup Hyg 42: 521-530, 1998

Fung H. Kow YW, Van Houten B. Taatjes DJ, Hatahet Z. Janssen YM. Vacek P. Faux SP, Mossman BT. Asbestos increases mammalian AP-endonuclease gene expression, protein levels, and enzyme activity in mesothelial cells. Cancer Res 58 : $189-94,1998$

Fulton AM, Loveless SE. Heppner GH. Mutagenic activity of tumor-associated macrophages in Salmonella typhimurium strains TA98 and TA 100. Cancer Res 44: 4308-4311. 1984.

Gallagher J. Heinrich U. George M. Hendee L. Phillips DH. Lewtas J. Formation of DNA adducts in rat following chronic inhalation of diesel emissions, carbon black and titanium dioxide. Carcinogenesis 15: 1291-1299. 1994

Gera JF, Lichtenstein A. Human neutrophil peptide defensins induce single strand DNA breaks in target cells. Ce/l Immunol 138: 108-120, 1991.

Gercken G. Berg I, Dorger M. Schluter T. Mechanisms of particle-induced activation of alveolar macrophages. Toxicol Letl 88: 121-129, 1996

Ghio AJ, Richards JH. Carter JD. Madden MC. Accumulation of iron in the rat lung after tracheal instillation of diesel particles. Toxicol Pathol 28: 619-627, 2000. 
Ghio AJ, Devlin RB. Inflammatory lung injury after bronchial instillation of air pollution particles. Am J Respir Crit Care Med 164: 704-708, 2001.

Ghosh R, Mitchell DL. Effect of oxidative DNA damage in promotor elements on transcription factor binding. Nucleic Acid Res 27: 3213-3218, 1999.

Gilmour PS, Beswick PH, Brown DM, Donaldson K. Detection of surface free radical activity of respirable industrial fibres using supercoiled pX174 RFI plasmid DNA. Carcinogenesis 16:2973-2979, 1995.

Godleski J, Verrier RL., Koutrakis P, Catalano P, Coull B, Reinisch U, Lovett EG, Lawrence J, Murthy GG, Wolfson JM. Clarke RW, Nearing BD, Killingsworth C. Mechanisms of morbidity and mortality from exposure to ambient air particles. Res Rep Health Eff Inst 91: 5-88, 2000.

Gosset P, Lasalle P, Vanhee D, Wallaen B, Aerts C, Voisin C, Tonnet AB. Production of tumor necrosis factor- and intereukin-6 by human alveolar macrophages exposed in vitro to coal mine dust. Am J Respir Cell Mol Biol 5: 431-436. 1991.

Greim H, Borm PJA, Schins RPF, Donaldson K, Driscoll KE, Hartwig A, Kuempel E, Oberdörster G, Speit G. Toxicity of fibers and particles. Report of the workshop held in Munich, Germany, 26-27th October 2000. Inhal Toxicol 13, 101-119. 2001.

Gross A; Dugas N, Spiesser S, Vouldoukis I, Damais C, Kolb JP, Dugas B, Dornand J. Nitric oxide production in human macrophagic cells phagocytizing opsonized zymosan: direct characterization by measurement of the luminol dependent chemiluminescence. Free Radic Res 28: 179-191, 1998.

Guo FH. De Raeve HR, Rice TW. Stuchr DJ. Thunnissen FBJM. Errurum ASC. Continuous nitric oxide synthesis by inducible nitric oxide synthase in normal human airway epithelium in vivo. Proc Natl Acad Sci USA 92: 7809.7813, 1995

Guschlbauer W, Duplaa AM, Guy A. Teoule R, Fazakerley GV. Structure and in vitro replication of DNA templates containing 7,8-dihydro-8-oxoadenine. Nucleic Acids Res 19: 1753-1758, 1991

Gutteridge JMC. Iron promotors of the Fenton reaction and lipid peroxidation can be released from hacmoglobin by peroxides. FEBS Leth 201:291-295, 1986.

Hagen IM. Huang S, Curnutte J. Fowler P, Martinez V. Wehr CM. Ames BN, Chisari FV. Fxtensive oxidative DNA damage in hepatocytes of transgenic mice with chronic active hepatitis destined to develop hepatocellular carcinoma. Proc Nat/ Acad Sci US. 91 : 12808-12812, 1994

Hansen K, Mossman BT. Generation of superoxide (O2-.) from alveolar macrophages exposed to asbestiform and nonfibrous particles. Cancer Res 15: 1681-1686, 1987.

Hansen WK. Kelley MR. Review of mammalian DNA repair and translational implications. J Pharmacol Exp Therap 295: 1. 9. 2000.

Hall M, Grover PL. Polycyelic aromatic hydrocarbons: metabolism, activation and tumor initiation. In: Cooper CS, Grover Pl. (eds), Chemical carcinogenesis and mutagenesis. Berlin, Springer Verlag, 327-272, 1990.

Halliwell B, Gutteridge JMC. Free radicals in biology and medicine. Clarendon Press, Oxford, 1985.

Halliwell B. Aruoma OI. DNA damage by oxygen-derived species. Its mechanism and measurement in mammalian systems. FEBS Lell 281:9-19,1991.

Hampton MB, Kettle AJ. Winterbourn CC. Inside the neutrophil phagosome: oxidants, myeloperoxidase, and bacterial killing. Blood 92: 3007-3017, 1998 .

Haugen TS, Skjonsberg OH, Kahler H. Lyberg T. Production of oxidants in alveolar macrophages and blood leukocytes. Eur Resp J14: 1100-1105, 1999

Hedenborg M. Klockars M. Quarz-dust-induced production of reactive oxygen metabolites by human granulocytes. Lung 167:23-32, 1989

Hevel JM. White KA, Marletta MA. Purification of the inducible murine macrophage nitric oxide synthase. J Biol Chem 266: 22789-22791, 1991.

Hitzfeld B, Friedrichs KH. Ring J. Behrendt H. Airborne particulate matter modulates the production of reactive oxygen species in human polymorphonuclear granulocytes. Taxicol 120: 185-195, 1997.

Höh D, Steinfartz Y, Schins RPF, Knaapen AM, Martra G, Fubini B, Borm PJA. Hydrophobic coating of ultrafine titanium dioxide reduces the acute inflammatory response after instillation in the rat. Int J Hox Environ Health, 2002 in press.

Hornberg C, Maciuleviciute L. Seemayer NH. Kainka E. Induction of sister chromatide exchanges (SCE) in human tracheal epithelial cells by the fractions PM-10 and PM-25 of airborne particulates. Toxicol Left 96-97:215-220, 1998.

Hsiao WL. W. Mo ZY, Fang M. Shi XM. Wang F. Cytotoxicity of PM, s and PM , , 10 ambient air pollutants assessed by the MTT and the Comet assays. Mfutat Res 471:45-55, 2000.

Huftman I.J. Judy DJ. Castranova V. Regulation of nitric oxide production by rat alveolar macrophages in response to silica exposure. J Toxicol Emviron Health 53: 29-46, 1998.

Huic RE. Padmaja S. The reaction of NO with superoxide. Free Radic Res Commun 18: 195-199. 1993.

Hunninghake GW. Gadek JE, Lawly TJ, Cnstal RG. Mechanisms of neutrophil accumulation in the lungs of patients with idiopathic pulmonary discase. J C lin Imvest 68: 259-269. 1981

IARC. IARC Monograph on the Fvaluation of the Carcinogenic Rish of Chemicals to Humans, Vol. 68 : silica, some silicates, coal dust and para-aramid fibrils. IARC Press, Geneva. Switzerland, 1997

II.SI report. The relevance of the rat lung response to particle overload for human risk assessment: a workshop consensus report. II.SI Risk Science Institute Workshop Participants. Inhal Toxicol 12:1-17, 2000.

lyer GYN. Islam MF, Quastel JH. Biochemical aspects of phagocvtosis. Nature 192:535.541, 1961

Jackson JH. Gajewski L, Schraufstatter IU, Hyslop PA. Fuciarelli AF. Cochrane CG. Dizdaroglu M. Damage to hases in DNA induced by stimulated human neutrophils. J Clin Imest 84: 1044-1649. 1989

Jackson JH. Potential molecular mechanisms of oxidant-induced carcinogenesis. Emviron Health Perspect 102(suppl 10): 155-157. 1094. 
Jaiswal M, LaRusso NF, Nishioka N, Nakabeppu Y, Gores GJ. Human Oggl, a protein involved in the repair of 8 . oxoguanine, is inhibited by nitric oxide. Cancer Res 61: 6388-6393, 2001.

Janssen YMW, Marsh JP, Absher MP, Hemenway D, Vacek PM, Leslie KO, Borm PJA. Mossman BT. Expression of antioxidant enzymes in rat lungs after inhalation of asbestos or silica. J Biol Chem 267: 10652-10630, 1992.

Johnson NF, Smith DM, Sebring R. Holland LM. Silica-induced alveolar cell tumors in rats. Am J Ind Med 11: 93-107, 1987.

Kamp DW, Dunn MM, Sbalchiero JS, Knap AM. Wietzman SA. Contrasting effects of alveolar macrophages and neutrophils on asbestos-induced pulmonary epithelial cell injury. Am J Physiol 266, 1.84-1.91, 1994.

Kamp DW, Srinivasan M, Weitzman SA. Cigarette smoke and asbestos activate poly-ADP-ribose polymerase in alveolar epithelial cells. J Investig Med 49: 68-76, 2001.

Kantor AF, Hartge P. Hoover RN, Narayana AS, Sullivan JW, Fraumenti JF Jr. Urinary tract infection and risk of bladder cancer. Am J Epidemiol 119: 510-515, 1984.

Kasai $\mathrm{H}$, Nishimura $\mathrm{S}$. Hydroxylation of deoxyguanosine at the $\mathrm{C}-8$ position by ascorbic acid and other reducing agents. Nucl Acids Res 4, 2137-2145, 1984.

Keane MJ, Xing SG, Harrison JC, Ong T, Wallace WE. Genotoxicity of diesel-exhaust particles dispersed in simulated pulmonary surfactant. Mutat Res 260: 233-238, 1991.

Kensler TW, Egner PA, Moore G, Taffe BG, Twerdok LE, Trush MA. Role of inflammatory cells in the metabolic activation of polycyclic aromatic hydrocarbons in mouse skin. Toxicol Appl Pharmacol 90: 337-346, 1987.

Keyer K. Imlay JA. Superoxide accelerates DNA damage by elevating free-iron levels. Proc Natl Acod Sci USA 93: 13635 . $13640,1996$.

Kim HN, Morimoto Y, Tsuda T, Ootsuyama Y, Hirohashi M. Hirano T, Tanaka I, Lim Y, Yun IG, Kasai H. Changes in DNA 8-hydroxyguanine levels, 8-hydroxyguanine repair activity, and hOGGI and hMTHI mRNA expression in human lung alveolar epithelial cells induced by crocidolite asbestos. Carcinogenesis 22: 265-269, 2001.

Kinnula VL. Everitt J, Whorton AR, Crapo JD. Hydrogen peroxide production by alveolar type II cells, alveolar macrophages, and endothelial cells. Am J Physiol 261: L84-91, 1991.

Kinnula VL, Chang L. Everitt JI, Crapo JD. Oxidants and antioxidants in alveolar epithelial type II cells: in situ, freshly isolated and cultured cells. Am J Physiol 262: L-69-77, 1992.

Kinnula VL. Crapo JD, Raivio KO. Generation and disposal of reactive oxygen metabolites in the lung. Lab Imvestig 73: 3 . $19,1995$.

Klebanoff SJ. A peroxidase-mediated antimicrobial system in leukocytes. J Clin Imvest 46: 1478, 1967.

Klebanoff SJ. Myeloperoxidase-halide-hydrogen peroxide antibacterial system. J Bacteriol 95; 2131-2138, 1968

Klebanoff SJ. Myeloperoxidase. Proc Ass Am Phys 111: 383-389, 1999.

Klebanoff SJ. Nathan CF. Nitrite production by stimulated human polymorphonuclear leukocytes supplemented with azide and catalase. Biochem Biophys Res Commun 197: 192-196, 1993.

Klockars M. Hedenborg M. Vanhala E. Effect of two particle surface-modifying agents, polyvinylpyridine- $\mathrm{N}$-oxide and carboxymethylcellulose, on the quartz and asbestos mineral fiber-induced production of reactive oxygen metabolites by human polymorphonuclear leukocytes. Arch Emviron Health 45: 8-14, 1990.

Knaapen AM, Den Hartog GJ, Bast A, Borm PJA. Ambient particulate matter induces relaxation in rat aortic rings in vitro. Hum Exp Toxicol 20: 259-265, 2001.

Kohn KW, Erickson LC, Ewig RAG, Friedman CA. Fractionation of DNA from mammalian cells by alkaline elution. Biochemistry 15: 4629-4637, 1976.

Kojda G, Harrison D. Interactions between NO and reactive oxygen species: pathophysiological importance in atherosclerosis, hypertension, diabetes and heart failure. Cardiovascular Research 43: 562-571. 1999.

Kondo S, Toyokuni S, Iwasa Y. Tanaka T. Onodera H. Hiai H. Imamura M. Persistent oxidative stress in human colorectal carcinoma, but not in adenoma. Free Radic Biol Med 27: 401-410, 1999

Kuchino Y, Mori F. Kasai H. Inoue H. Iwai S, Miura K. Ohtsuka E, Nishimura S. Misreading of DNA templates containing 8-hydroxydeoxyguanosine at the modified base and at the adjacent residues. Nature 327: 77-79, 1987.

Kuempel ED, O'Flaherty EJ, Stayner LT, Smith RJ, Green FH, Vallyathan V. Biomathematical model of particle clearance and retention in the lungs of coal miners. Regul Toxicol Pharmacol 34:69-87, 2001.

Kulcharyk PA. Heinecke JW. Hypochlorous acid produced by the myeloperoxidase system of human phagocytes induces covalent cross-links between DNA and protein. Biochemistry 40: 3648-3656, 2001

Kunkel SL: Standiford T. Kasahara K. Strieter RM. Interleukin-8 (IL-8): the major neutrophil chemotactic factor in the lung. Exp Lung Res 17: 17-23, 1991.

Leanderson P. Tagesson C. Hydrogen peroxide release and hydroxyl radical formation in mixtures containing mineral fibres and human neutrophils. $B$ J Ind Med 49: 745-749, 1992.

Lentsch AB, Czermak BJ. Bless NM. Van Rooijen N. Ward PA. Essential role of alveolar macrophages in intrapulmonary activation of NF- B. Am J Respir Cell Mol Biol 20: 692-698, 1999.

Lewis JG, Adams DO. Inflammation, oxidative DNA damage, and carcinogenesis. Emviron Health Perspect 76: 19-27, 1987.

Li XY. Brown D. Smith S. MacNee W, Donaldson K. Short-term inflammatory responses following intratracheal instillation of fine and ultrafine carbon black in rats. Inhal Toxicol 11: 709-31, 1999.

Liu X. Keane MJ. Thong B. Ong T. Wallace WE. Micronucleus formation in V79 cells treated with respirable silica dispersed in medium and in simulated pulmonary surfactant. Mutat Res 361: 89-94, 1996

Lloyd RV. Hanna PM. Mason RP. The origin of the hydroxyl radical oxygen in the fenton reaction. Free Radic Biol Med 22 : 885-888, 1997.

Lloyd DR. Carmichael PL. Phillips DH. Comparison of the formation of 8-hydroxy-2 -deoxyguanosine and single- and double-strand breaks in DNA mediated by Fenton reactions. Chem Res Toxicol 11: 420-427, 1998.

Lu PJ. Ho IC. Lee TC. Induction of sister chromatide exchanges and micronuclei by titanium dioxide in chinese hamster ovary-K1 cells. Mutat Res 414: 15-20, 1998. 
Lutgerink J, van den Akker E, Smeets I, Pachen D, van Dijk P. Aubry JM, Joenje H, Lafleur MV, Retel J. Interaction of singlet oxygen with DNA and biological consequences. Mutat Res 275: 377-386, 1992a.

Lutgerink $\pi$, de Graaf E, Hoebee B, Stavenuitez HF, Westra JG, Kriek E. Detection of 8-hydroxyguanine in small amounts of DNA by 32P postlabeling. Anal Biochem 201: 127-133, 1992b.

Marnett L.J. Oxyradicals and DNA damage. Carcinogenesis 21: 316-370, 2000.

Mauderly Jl. Relevance of particle-induced rat lung tumors for assessing lung carcinogenic hazard and human lung cancer risk. Emviron Healıh Perspect 105 (suppl 5): 1337-1346, 1997.

MeCord JM, Fridovich I. Superoxide dismutase. An enzymic function for erythrocuprein. J Biol Chem 244: 6049-6055. 1969

MeDonald RJ, Pan LC, St Georg JA, Hyde DM, Ducore JM. Hydrogen peroxide induces DNA single strand breaks in respiratory epithelial cells. Inflammation 17:715-722, 1993

Meier B, Radeke HH, Selle S, Raspe HH, Sies H, Resch K, Habermehl GG. Human fibroblasts release reactive oxygen species in response to treatment with synovial fluids from patients suffering from arthritis. Free Radic Res Commun 8 : 149-160, 1990.

Metchnikoff E. Untersuchungen aber die intracelluläre Verdauung by wirbellosen Thieren. Arb Zool Inst Univ Wien 5: 141, 1883.

Miller MD, Krangel MS. Biology and biochemistry of the chemokines: a family of chemotactic and inflammatory cytokines. Crit Rev Immunol 12: 17.46, 1992.

Morrow PE. Possible mechanisms to explain dust overloading of the lungs. Fundam Appl Toxicol 10:369-384, 1988.

Mullen PG, Windsor ACJ. Walsh CJ. Fowler AA. Sugerman H. Tumor necrosis factor- and interleukin-6 selectively regulate neutrophil function in vitro. J Surg Res 58: 124-130, 1995.

Murphy PM, Packer MA, Scarlett J., Martin SW. Peroxynitrite: A biologically significant oxidant. Gen Pharmac 31 : 179. 186,1998

Nehls P, Seiler F, Rehn B, Greferath R, Bruch J. Formation and persistence of 8-oxoguanine in rat lung cells as an important determinant for tumor formation following particle exposure. Emv Health Persp: 105(suppl 5), 1291-1296, 1997

Nathan CF. Neutrophil activation on biological surfaces. Massive secretion of hydrogen peroxide in response to products of macrophages and lymphocytes. J Clin Imvest 80: 1550-1560 (1987).

Nikula KJ, Snipes MB, Barr EB, Griffith WC. Henderson RF, Mauderly J. Comparative pulmonary toxicities and carcinogenicities of chronically inhaled diesel exhaust and carbon black in F344 rats. Fundam Appl Toxicol 25: 80-94. 1995.

Noguera A, Batle S, Miralles C, Iglesias J, Busquets X, MacNee W, Agusti AG. Enhanced neutrophil response in chronic obstructive pulmonary discase. Thorax $56: 432-437,2001$

Nguyen T, Brunson D. Crespi Cl. Penman BW. Wishnok JS. Tannenbaum SR. DNA damage and mutation in human cells exposed to nitric oxide in vitro. Proc Natl Acad Sci 89: 3030-3034, 1992.

Nyberg P. Polyvinylpyridine- $\mathrm{N}$-oxide and carboxymethyl cellulose inhibit mineral dust-induced production of reactive oxygen species by human macrophages. Emviron Res 55: 157-164, 1991.

Oberdorster G. Pulmonary effects of inhaled ultrafine particles. Int Arch Occup Environ Health 74: 1-8, 2001.

Okamoto K. Toyokuni S, Uchida K, Ogawa O, Takenawa J, Kakehi Y, Kinoshita H, Nakakuki Y, Hiai H. Yoshida O. Formation of 8 -hydroxy-2'-deoxyguanosine and 4-hydroxy-2-nonenal-modified proteins in human renal-cell carcinoma. Int J Cancer 58: 825-829, 1994

Ostling $\mathrm{O}$, Johanson $\mathrm{KJ}$. Microelectrophoretic study of radiation-induced DNA damages in individual mammalian cells. Biochem Biophs Res Commun 123:291-298, 1984.

Padgett EL. Pruett SB. Rat, mouse and human neutrophils stimulated by a variety of activating agents produce much less nitrite that rodent macrophages, Immunology 84: 135-141, 1995.

Pairon JC, Jaurand MC, Kheuang L. Janson X. Brochard P, Bignon J. Sister chromatide exchanges in human lymphocytes treated with silica. Br.J Ind Health 47: 110-115, 1990

Park JW. Floyd RA. Lipid peroxidation products mediate the formation of 8 -hydroxydeoxyguanosine in DNA. Free Radic Biol Med 12: 245-250, 1992

Perderiset M, Marsh JP, Mossman BT. Activation of protein kinase C by crocidolite asbestos in hamster tracheal epithelial cells. Carcinogenesis 12: 1499-1502, 1991.

Pero RW, Sheng Y, Olsson A, Bryngelsson C, I und-Pero M. Hypochlorous acid/N-chloramines are naturally produced DNA repair inhibitors. Carcimogemesis 17: 13-18, 1996

Peters A, Skorkovsky J, Kotesovec F, Brynda J, Spix C, Wichmann HE, Heinrich J. Associations between mortality and air pollution in central Europe. Emvironmental Health Perspectives 108: 283-287, 2000.

Piguet PF. Collart MA. Grau GE, Sappino AP. Vassali P. Requirement of tumour necrosis factor for development of silicainduced pulmonary fibrosis. Nature 344(6263): 245-247, 1990

Pope CA III, Burnet RT. Thun MJ, Calle EE, Krewski D, Ito K. Thurston GD. Lung cancer, cardiopulmonary mortality, and long-term exposure to fine particulate air pollution. J.AMA 287:1132-1141, 2002

Prahalad AK. Soukup JM. Inmon J. Willis R. Ghio AJ. Becker S, Gallagher JE. Ambient air particles: effects on cellular oxidant radical generation in relation to particulate elemental chemistry. Toxicol Appl Pharmacol 158: 81-91. 1999.

Prahalad, AK, Inmon J, Dailey L.A. Madden MC, Ghio AJ, Gallagher JE: Air pollution particles mediated oxidative DNA base damage in a cell free system and in human airway epithelial cells in relation to particulate metal content and bioreactivity. Chem Res Toxicol 14: 879-887, 2001

Pryor WA. Why is the hydroxyl radical the only radical that commonly adds to DNA? Hypothesis: it has a rare combination of high electrophilicity, high thermochemical reactivity, and a mode of production that can occur near DNA. Free Rodic Biol Mod 4: 219.223, 1988. 
Pryor WA, Squadrito GL. The chemistry of peroxynitrite: a product from the reaction of nitric oxide with superoxide. Am J Physiol 268: L699-722, 1995.

Rahman I, MacNee W. Role of oxidants/antioxidants in smoking-induced lung diseases. Free Radic Biol Med 21: 669-681, 1996.

Ramon O, Sauvaigo S, Gasparutto D, Faure P. Favier A, Cadet J. Effects of 8-oxo-7,8-dihydro-2'-deoxyguanosine on the binding of the transcription factor Spl to its cognate target DNA sequence (GC box). Free Radic Res 31:217-229, 1999.

Ramos Cl, Pou S, Britigan BE, Cohen MS, Rosen GM. Spin trapping evidence for myeloperoxidase-dependent hydroxyl radical formation by human neutrophils and monocytes. J Biol Chem 267: 8307-8312, 1992.

Randerath K. Reddy MV, Gupta RC. ${ }^{13}$ P-postlabeling test for DNA damage. Proc Natl Acad Sci US.4 78: 6126-6129, 1981.

Renwick LC, Donaldson K. Clouter A. Impairment of alveolar macrophage phagocytosis by ultrafine particles. Toxicol Appl Pharmacol 172: 119-127, 2001.

Rich EA, Panuska JR, Wallis RS, Wolf CB, Leonard ML. Ellner JJ. Dyscoordinate expression of tumor necrosis factor-alpha by human blood monocytes and alveolar macrophages. Am Rev Respir Dis 139; 1010-1016, 1989.

Robock K. Standard quartz DQ12<5 $\mu \mathrm{m}$ for experimental pneumoconiosis research project in the federal republic of Germany. Ann Occup Hyg 16: 63-66, 1973.

Satoh MS, Lindahl T. Enzymatic repair of oxidative DNA damage. Cancer Res 54 (suppl): 1899-1901, 1994.

Schins RPF, McAlinden A, MacNee W, Jimenez LA, Ross JA, Guy K. Faux SP. Donaldson K. Persistent depletion of I kappa B alpha and interleukin-8 expression in human pulmonary epithelial cells exposed to quartz particles. Toxicol Appl Pharmacol 167: 107-17, 2000.

Schins RPF, Shi T, Knaapen AM, Borm PJA. In vitro inflammatory effects of coarse and fine particulate matter. Ann Occup Hyg 2002a, in press.

Schins RPF. Mechanisms of genotoxicity of particles and fibres. Inhal Toxicol 14: 57-78, 2002b.

Schraufstaitter I. Hyslop PA. Jackson JH. Cochrane CG. Oxidant-induced DNA damage of target cells. J Clin Imvest. 82 1040-1050, 1988.

Schwartz J. Air pollution and hospital admissions for heart disease in eight U.S. counties. Epidemiology 10: 17-22, 1999.

Seaton A, MacNee W. Donaldson K, Godden D. Particulate air pollution and acute health effects. Lancet 345: 176-178, 1995.

Seemayer NH, Hornberg C, Hadnagy W. Comparative genotoxicity testing of airborne particulates using rodent tracheal epithelial cells and human lymphocytes in vitro. Toxicol Lett 72: 95-103, 1994.

Seiler F, Rehn B, Rehn S, Bruch J. Quartz exposure of the rat lung leads to a linear dose response in inflammation but not in oxidative DNA damage and mutagenicity. Am J Respir Cell Mol Biol 24: 492-498, 2001.

Selby C, Drost E. Lannan S. Wraith PK. MacNee W. Neutrophil retention in the lungs of patients with chronic obstructive pulmonary disease. Am Rev Respir Dis 143: 1359-1364, 1991.

Shacter E, Beecham EJ. Covey JM. Kohn WW. Activated neutrophils induce prolonged DNA damage in neighboring cells. Carcinogenesis 9:2297-2304, 1988.

Shacter E, Lopez RL., Beecham EJ, Janz S. DNA damage induced by phorbol ester-stimulated neutrophils is augmented by extracellular cofactors. Role of histidine and metals. J Biol Chem 265: 6693-6699. 1990.

Shen Z, Wu W, Hazen SL. Activated leukocytes oxidatively damage DNA, RNA, and the nucleotide pool through halidedependent formation of the hydroxyl radical. Biochemistry 39:5474-5482, 2000.

Shi X. Mao Y, Daniel LN, Saffiotti U, Dalal NS, Vallyathan V. Silica radical-induced DNA damage and lipid peroxidation. Environ Health Perspect 102 (suppl 10): 149-154, 1994

Shimoda R, Nagashima M. Sakamoto M. Yamaguchi N. Hirohashi S. Yokota J, Kasai H (1994). Increased formation of oxidative DNA damage, 8-hydroxydeoxyguanosine, in human livers with chronic hepatitis. Cancer Res 54: 3171 -3172. 1994.

Shukla A. Timblin C, Berube K, Gordon T, McKinney W, Driscoll K, Vacek P. Mossman BT. Inhaled particulate matter causes expression of nuclear factor (NF)-kappaB-related genes and oxidant-dependent NF-kappaB activation in vitro. Am J Respir Cell Mol Biol 23: 182-187, 2000.

Sibille Y. Reynolds HY. Macrophages and polymorphonuclear neutrophils in lung defence and injury. Am Rev Respir Dis 141: 471-501, 1990.

Sibille Y. Marchandise FX. Pulmonary immune cells in health and disease: polymorphonuclear neutrophils. Eur Respir J 6: 1529-1543. 1993.

Simon RH. DeHart PD. Todd RF $3^{\text {ns }}$. Neutrophils-induced injury of rat pulmonary alveolar epithelial cells. J Clin Imvest 78 : 1375-1386, 1986.

Simon RH. Paine R. Participation of pulmonary alveolar epithelial cells in lung inflammation. J Lab Clin Med 126: 108-118. 1995.

Singh NP. McCoy MT. Tice RR. Schneider EL. A simple technique for quantitation of low levels of DNA damage in individual cells. Exp Cell Res 175: 184-191, 1988.

Skillrud DM. Offord KP. Miller RD. Higher risk of lung cancer in chronic obstructive pulmonary disease. A prospective, matched, controlled study. Ann Intern Med 105: 503-507, 1986.

Soukup JM. Becker S. Human alveolar macrophage responses to air pollution particulates are associated with insoluble components of coarse material, including particulate endotoxin. Toxicol Appl Pharmacol 171. 20-26. 2001

Soultanakis RP. Melamede RJ. Bespalov IA. Wallace SS, Beckman KB, Ames BN, Taatjes DJ. Janssen-Heininger YMW. Fluorescence detection of 8-oxoguanine in nuclear and mitochondrial DNA of cultured cells using a recombinant Fab and confocal scanning laser microscopy. Free Radic Biol Med 28: 987-998, 2000.

Spencer JPE, Jenner A. Chimel K. Aruoma OI. Cross CE, Wu R. Halliwell B. DNA strand breakage and base modification induced by hydrogen peroxide treatment of human respiratory tract epithelial cells. FE.BS /eft 374: 233-236, 1995. 
Spencer JPE, Whiteman M, Jenner A, Halliwell B. Nitrite-induced deamination and hypochlorite-induced oxidation of DNA in intact human respiratory tract epithelial cells. Free Radic Biol Med 28: 1039-1050, 2000.

Standiford TJ, Kunkel SL. Basha MA, Chesue SW, Lynch III JP, Toews GB, Westwick J, Strieter RM. Interleukin-8 gene expression by a pulmonary epithelial cell line. A model for cytokine networks in the lung. J Clin Imvest 86: 1945-1953, 1990.

Standiford TJ, Kunkel SI. Phan SH, Rollins BJ, Strieter RM. Alvelar macrophages-derived cytokines induced monocyte chemoattractant protein-I from human pulmonary type II-like epithelial cells. $J$ Biol Chem 266: 9912-9918, 1991.

Steerenberg PA. Zonnenberg JA. Dormans JA, Joon PN, Wouters IM, van Bree L, Scheepers PT, Van Loveren H. Diesel exhaust particles induced release of interleukin 6 and 8 by (primed) human bronchial epithelial cells (BEAS 2B) in vitro. Exp Lung Res 24: 85-100, 1998.

Stewart BW. Mechanisms of apaptosis: integration of genetic, biochemical, and cellular indicators. $J$ Natl Cancer Inst 86: 1286-1296, 1994.

Stierum RH. Modulation of DNA repair. Studies on the xenobiotic activation of poly(adenosine diphosphate ribosylation) in humans. Thesis. Unigraphic, Maastricht University, The Netherlands.

Strieter RM, Kunkel SL. Acute lung injury: the role of cytokines in the elicitation of neutrophils. J Investig Med 42: 640-65I. 1994.

Suwa T, Hoge JC, Quinlan KB, Ohgami A, Vincent R, Van Eeden SF. Particulate air pollution induces progression of atherosclerosis. J Am Coll Candiol 39: 935-942, 2002.

Suruki YJ, Forman HJ. Sevanian A. Oxidants as stimulators of signal transduction. Free Radic Biol Med 22: 269-285, 1997.

Swain JA, Darley-Usmar V. Gutteridge JMC. Peroxynitrite releases copper from cacruloplasmin: implications for atherosclerosis. FEBS Lett 342: 49-52, 1994

Tan X. Grollman AP. Shibutani S. Comparison of the mutagenic properties of 8-oxo-7,8-dihydro-2'-deoxyadenosine and 8oxo-7,8-dihydro-2'-deoxyguanosine DNA lesions in mammalian cells. Carcinogenesis 12:2287-2292, 1999

Tate RM, Repine UE. Neutrophils and the adult respiratory distress syndrome. Am Rev Respir Dis 128: 52-59, 1983.

Tice RR, Agurell E, Anderson D, Burlinson B, Hartmann A, Kobayashi H, Miyamae Y, Rojas E, Ryu JC, Sasaki YF. Single cell gel/comet assay: guidelines for in vitro and in vivo genetic toxicology testing. Environ Mol Mutagen 35: 206-221, 2000.

Toyokuni S, Tanaka T, Hattori Y. Nishiyama Y, Yoshida A, Uchida K. Hiai H, Ochi H, Osawa T. Quantitative immunohistochemical determination of 8 -hydroxy-2'-deoxyguanosine by a monoclonal antibody N45.1: Its application to ferric nitrolotriacetate-induced renal carcinogenesis model. Lab Imvestig 76: 365-374, 1997.

Trush MA, Seed JI. Kensler TW. Oxidant-dependent metabolic activation of polycyclic aromatic hydrocarbons by phorbol ester-stimulated human polymorphonuclear leukocytes: Possible link between inflammation and cancer. Proc Nall Acad Sci USA 82: 5194-5198, 1985

Tsurudome Y. Hirano T, Yamato H, Tanaka I, Sagai M, Hirano H. Nagata N, Itoh H. Kasai H. Changes in levels of 8 hydroxyguanine in DNA, its repair and OGGI mRNA in rat lungs after intratracheal administration of diesel exhaust particles. Carcinogenesis 20: 1573-1576, 1999.

Tuo J. Liu L. Poulsen HE, Weimann A, Svendsen O, Loft S. Importance of guanine nitration and hydroxylation in DNA in vitro and in vivo. Fre Radic Biol Med 29: 147-155, 2000.

Tuomala M. Hirvonen MR. Holopainen M. Savolainen K. Stimulation of human polymorphonuclear leukocytes by consequtive doses of quartz and interactions of quartz with IML.P. Toxicol Appl Pharmacol 118: 224-232, 1993a.

Tuomala M. Hirvonen MR. Savolainen KM. Changes in free intracellular calcium and production of reactive oxygen metabolites in human leukocytes by soluble and particulate stimuli. Toxicol 80: 71-82, 1993b.

Turk PW, Weitzman SA. Free radical DNA adduct 8-OH-deoxyguanosine affects activity of Hpa II and Msp I restriction endonucleases. Frev Radic Res 23: 255-258, 1995

Van Feden SF, Tan WC, Suwa T. Mukae H. Terashima T. Fujii T, Qui D. Vincent R. Hogg JC. Cytokines involved in the systemic inflammatory response induced by exposure to particulate matter air pollutants (pm(10)). Am J Respir Crit Care Mod 164: 826-30, 2001.

Vallyathan V. Shi X. Dalal NS, Irr W. CastranovaV. Generation of free radicals from freshly fractured silica dust: potential role in acute silica-induced lung injury. Am Rev Respir Dis 138: 1213-1219, 1988

Vallyathan V, Kang JH, Van Dyke K. Dalal NS, Castranova V. Response of alveolar macrophages to in vitro exposure to freshly fractured versus aged silica dust: the ability of prosil 28 , an organosilane material, to coat silica and reduce its biological activity. J Toxicol Emviron Health 33: 303-315, 1991.

Vallyathan V. Mega JF, Shi X. Dalal NR. Enhanced generation of free radicals from phagocytes induced by mineral dusts. Am J Respir Cell Mol Biol 6: 404-413, 1992.

Van den Akker E. Lutgerink J. Lafleur MVM, Joenje H. Retel J. The formation of one-G deletions as a consequence of singlet-oxygen-induced DNA damage. Matat Res 309:45-52, 1994

Van der Vliet A. Bast A. Effect of oxidative stress on receptors and signal transmission. Chem Biol Interact 85: 95-116, 1902

Van der Vliet A. Fiserich JP. Halliwell B. Cross CE. Formation of reactive nitrogen species during peroxidase-catalyzed oxidation of nitrite: A potential additional mechanism of nitric oxide-dependent toxicity. $J$ Btol Chem 272:7617.7625. 1907

Van der Vliet A, O'Neill CA, Cross CF, Koostra JM, Volz WG. Halliwell B, Louie S. Determination of low-molecular-mass antioxidant concentrations in human respiratory tract lining fluids. Am J Phsiol 276, 1.289-1.296, 1999

Van Klaveren RJ. Roelant C, Boogacrts M. Demedts M. Nemery B. Involvement of an NAD(P)H oxidase-like enzyme in superoxide anion and hydrogen peroxide generation by rat type II cells. Thonax 52:465-471, 1997. 
Van Maanen JMS, Borm PJA, Knaapen AM, van Herwijnen M, Schilderman PAEL, Smith KR, Aust AE, Tomatis M, Fubini B. In vitro effects of coal fly ashes: Hydroxyl radical generation, iron release, and DNA damage and toxicity in rat lung epithelial cells. Inhal Toxicol 11: 1123-1141, 1999.

Van Schooten FJ. Polycyclic aromatic hydrocarbon-DNA adducts in mice and humans. Thesis. University of Leiden, The Netherlands.

Van Staden AM, van Rensburg CE, Anderson R. Vitamine E protects mononuclear leukocyte DNA against damage mediated by phagocyte-derived oxidants. Mutat Res 288: 257-262, 1993.

Virchow R. Cellular pathology, 7th edition. Translated by F. Chance. R.M. Dewitt, New York, 1860, p.554.

Wallace SS. AP endonucleases and DNA glycosylases that recognize oxidative DNA damage. Emviron Mol Mutagen 12: $431-477,1988$

Wang D, Kreutzer DA. Essigmann JM. Mutagenicity and repair of oxidative DNA damage: insights from studies using defined lesions. Mutat Res 400: 99-115, 1998.

Ward PA. Mechanisms of endothelial cell killing by $\mathrm{H}_{2} \mathrm{O}_{2}$ or products of activated neutrophils. Am J Med 91 (suppl 3C): 89 . 94, 1991.

Weinberg JB, Misukonis MA. Shami PJ et al.. Human mononuclear phagocyte inducible nitric oxide synthase (iNOS): analysis of iNOS mRNA, iNOS protein, biopertin, and nitric oxide production by blood monocytes and peritoneal macrophages. Blood 86: 1184-1195, 1995.

Weisburger JH. Williams GM. The distinction between genotoxic and epigenetic carcinogens and implications for cancer risk. Toxicol Sci 57: 4-5, 2000.

Weiss SJ. Tissue destruction by neutrophils. New Engl J Med 320: 365-376, 1989

Weitberg AB. Weitzman SA. Destrempes M. Latt SA. Stossel TP. Stimulated human phagocytes produce cytogenetic changes in cultured mammalian cells. New Engl J Med 308: 26-30, 1983.

Weitberg AB, Weitzman SA, Clark EP, Stossel TP. Effects of antioxidants on oxidant-induced sister chromatide exchange formation. J Clin Imvest 75: 1835-1841, 1985.

Weitzman SA, Stossel TP. Mutation caused by human phagocytes. Science 212:546-547, 1981.

Weitzman SA, Stossel TP. Effects of oxygen radical scavengers and antioxidants on phagocyte-induced mutagenesis. $J$ Immunol 128: 2770-2772, 1982

Weitzman SA, Stossel TP. Phagocyte-induced mutation in chinese hamster ovary cells. Cancer Letl 22:337-341, 1984

Weitzman SA, Weitberg AB, Clark EP. Stossel TP. Phagocytes as carcinogens: malignant transformation produced by human neutrophils. Science 227: 1231, 1985

Weitzman SA, Gordon LI. Inflammation and cancer: Role of phagocyte-generated oxidants in carcinogenesis. Blood 76: 655663. 1990.

Whiteman M, Spencer JP, Jenner A, Halliwell B. Hypochlorous acid-induced DNA base modification: potentiation by nitrite: biomarkes of DNA damage by reactive oxygen species. Biochem Biophys Res Commun 257: 527-526, 1999.

Wilson ME. Effects of bacterial endotoxins on neutrophil function. Rev Infect Dis 7: 404-418, 1985.

Wiseman H, Halliwell B. Damage to DNA by reactive oxygen and nitrogen species: role in inflammatory disease and progression to cancer. Biochem J 313, 17-29, 1996.

Wong GHW, Goeddel DV. Induction of manganous superoxide dismutase by tumor necrosis factor: possible protective mechanism. Science 242: $941-944,1988$

Yamano Y, Kagawa J, Hanaoka T, Takahashi T, Kasai H, Tsugane S, Watanabe S. Oxidative DNA damage induced by silica in vivo. Environ Res 69: 102-107, 1995.

Yamashina K. Miller KE. Heppner GH. Macrophage-mediated induction of drug-resistant variants in a mouse mammary tumor cell line. Cancer Res 46: 2396-2401, 1986.

Yan L. Vandivier RW. Suffredini AF, Danner RL. Human polymorphonuclear leukocytes lack detectable nitric oxide synthase activity. J Immunol 153: 1825-1834, 1994.

Yermilov V. Rubio J. Ohshima H. Formation of 8-nitroguanine in DNA treated with peroxynitrite in vitro and its rapid removal from DNA by depurination. FEBS Lett 376: 207-210. 1995.

Yoshida R, Ogawa Y, Takayanagi S. In isolated DNA, formamidopyrimidine-DNA glycosylase-sensitive sites determined by electrophoresis correspond to the amount of 8-oxo-7,8-dihydro-2'-deoxyguanosine by HPLC-ECD. Mutat Res 494: 55 . $61,2001$.

Yuen IS, Hartsky MA, Snajdr SI, Warheit DB. Time course of chemotactic factor generation and neutrophil recruitment in the lungs of dust-exposed rats. Am J Respir Cell Mol Biol 15: 268-74, 1996.

Zhang Y, Lee TC, Guillemin B, Yu MC, Rom WN. Enhanced IL-1-beta and tumor necrosis-alpha release and messenger RNA expression in macrophages from idiopathic pulmonary fibrosis or after asbestos exposure. $J /$ mmunol $150: 4188$. 4196. 1993

Zhang Z, Shen HM. Zhang QF. Ong CN. Involvement of oxidative stress in crystalline silica-induced cytotoxicity and genotoxicity in rat alveolar macrophages. Environ Res 82: 245-252. 2000.

Zhong BZ, Whong WZ, Ong TM. Detection of mineral-dust-induced DNA damage in two mammalian cell lines using the alkaline single cell gel/comet assay. Mutat Res 393: 181-187, 1997 


\section{Part 1}

\section{Primary genotoxicity}




\title{
Chapter 2
}

\section{Ambient particulate matter induces oxidative DNA damage in lung epithelial cells}

\author{
Ad M Knaapen', Roel PF Schins', Yvonne Steinfartz', Doris Höhr', \\ Lothar Dunemann'ㄹ. Paul JA Borm' \\ 'Department of Fibre \& Particle Toxicology and ${ }^{2}$ Department of Analytical chemistry. \\ Medical Institute of Environmental Hygiene. Auf 'm Hennekamp 50. \\ 40225 Düsseldorf, Germany
}

\begin{abstract}
Although epidemiological studies have established a correlation between $\mathrm{PM}_{10}$ levels and acute cardiovascular and respiratory complications, hardly any data is available on possible chronic effects such as cancer. The purpose of this study was to investigate the production of free radicals by ambient particulate matter (PM) and to link these data to oxidative DNAdamage in lung epithelial cells. In line with previous findings on $\mathrm{PM}_{10}$, supercoiled plasmid DNA was depleted by PM as well as PM supernatant $(\mathrm{p}<0.001)$ and this effect was reduced in the presence of mannitol $(5 \mathrm{mM})$. Using electron spin resonance (ESR) and the spin-trap DMPO we were able to show that hydroxyl radicals $\left({ }^{\circ} \mathrm{OH}\right)$ are generated by both PM suspensions and -supernatants. The DMPO-OH signal was completely abrogated when PM was pre-incubated with deferoxamine $(5 \mathrm{mM})$, indicating the importance of soluble iron in this process. Indeed, AAS analysis of the PM supernatant showed the presence of soluble Fe, $\mathrm{V}$ and $\mathrm{Ni}$ (respectively $253.0,14.7$, and $76.0 \mu \mathrm{g} / \mathrm{g}$ insoluble PM). To investigate the biological significance of "OH-formation by PM, 8-hydroxydeoxyguanosine (8-OHdG) was measured in a rat type II cell line by immunocytochemistry. The formation of this hydroxyl radicalspecific DNA adduct was increased 2 fold $(\mathrm{p}<0.01)$ after incubation with PM-supernatants and this effect was inhibited by deferoxamine $(p<0.01)$. In summary, our data provide direct evidence that ambient particulate matter generates hydroxyl radicals in acellular systems. Furthermore, we showed that these particulates induce the hydroxyl radical-specific DNA lesion 8-OHdG in lung target cells via an iron-mediated mechanism.
\end{abstract}

Based on: Inhalation Toxicology 12 (suppl 3): 125-132, 2000. 


\section{Introduction}

Ambient particulate matter (PM) exposure levels are correlated with the incidence of acute mortality and morbidity due to cardiovascular or pulmonary complications (Pope et al., 1995). PM is a complex mixture of aggregates of organic and inorganic compounds such as carbonaceous material, polyaromatic hydrocarbons, metals, salts and endotoxins. Although several of these constituents, such as polyaromatic hydrocarbons or metals, have the capacity to contribute to genetic damage, few studies concentrate on PM-induced genotoxicity. Hydroxyl radicals generated by PM are hypothesised to play an important role in PM-induced effects (Donaldson et al., 1997), and can be generated during the transition metal-catalysed Fenton reaction (Halliwell et al., 1989). Indeed, iron and other transition metals such as $\mathrm{Cu}$ and $\mathrm{Ni}$ are present in PM and seem to be related to many of its effects (Costa et al., 1997). In previous studies using coal fly ashes we and others showed that iron mobilisation was correlated with the production of hydroxyl radicals and genotoxicity in rat type II cells (van Maanen et al., 1999). However, no direct evidence is available for hydroxyl radical generation by PM. We hypothesised that PM-derived iron is involved in the induction of structural genetic damage in lung target cells, via its ability to catalyse the formation of hydroxyl radicals. Additionally, we tested the hypothesis that the radical generating capacity of PM is mainly located in a fraction that is not centrifugeable. Therefore, we investigated the generation of hydroxyl radicals $(\mathrm{OH})$ by total suspended particulate matter (PM) using electron spin resonance (ESR). Furthermore, we determined the induction of the hydroxyl radical-specific DNA lesion 8-hydroxydeoxyguanosine (8-OHdG) in rat type II epithelial cells, the target cell from which particle-related tumours are thought to be derived.

\section{Materials and Methods}

\section{Chemicals}

Albumin, Deferoxamine mesylate, Diaminobenzidine-tetrahydrochloride (DAB), 5,5dimethyl-1-pyrroline-n-oxide (DMPO), Hanks' balanced salt solution (HBSS), Ethidium bromide, Ham's F12 medium, Hepes buffer, Fetal calf serum, Mannitol, 3-(4,5dimethylthiazol-2-yl)-2,5-diphenyltetrazolium bromide (MTT), Phosphate buffered saline (PBS) and Trypsin/EDTA, were obtained from Sigma (St. Louis, MO). Hydrogen peroxide $\left(\mathrm{H}_{2} \mathrm{O}_{2}\right)$ was purchased from Fluka (Germany) and RNAse was obtained from Boehringer (Mannheim, Germany). ФX174RF-DNA was purchased from Life Technologies (The Netherlands). For ESR experiments deionized water was used (Millipore).

\section{Preparation and characterisation of PM}

PM was sampled in Duisburg Germany, (March 1995) on nitrocellulose filters (Pore size: 3 $\mu \mathrm{m}$, Sartorius, Germany) using a high volume sampler (HVS 150, Ströhlein Instruments, Germany). Duisburg is a highly industrialised city and is a center of iron, steel and coke production. To prepare PM suspensions, $45 \mathrm{~cm}^{2}$ filter cuts were immersed in HBSS, vortexed and sonicated ( 5 minutes) to release the particles from the filter. A blank filter was treated the same way and was used as a control in all experiments. The particle mass concentration of each preparation was estimated by filtering $500 \mu \mathrm{l}$ of the suspension through a $0.2 \mu \mathrm{m}$ filter and weighing the filter after drying. Although some of the PM is water-soluble this method was used to prepare suspensions with equal particle concentrations for all experiments. In some experiments, PM suspensions were centrifuged for 5 minutes at $10,000 \mathrm{~g}$ to obtain a clear supernatant (PM-sup). Particles in suspension or present in the supernatant were visualised using Scanning/Transmission Electronic Microscopy (STEM. Philips CM12). The 
inorganic elemental surface chemistry of both preparations was identified using Energy dispersive X-ray analysis (EDX).

\section{Plasmid DNA assay}

To investigate the free radical-generating capacity, $0.7 \mu \mathrm{g}$ of PM or its supernatant were incubated with $0.67 \mu \mathrm{g} \Phi \times 174 \mathrm{RF}-\mathrm{DNA}$ for $4 \mathrm{hrs}$ at $37^{\circ} \mathrm{C}$, as described by Donaldson et al., (1997). Subsequently, supercoiled, relaxed and linear DNA fragments were separated by electrophoresis on a $0.6 \%$ agarose gel $(12 \mathrm{~V}, 18 \mathrm{hrs})$. The DNA was stained with ethidium bromide, visualised with UV light and subsequently quantified by scanning laser densitometry-analysis. The percentage of supercoiled DNA was calculated as a fraction of total DNA per lane and was expressed as \% of control.

\section{Hydroxyl radical generation by $P M$}

PM suspensions in PBS $(3 \mathrm{mg} / \mathrm{ml})$ were incubated for $3 \mathrm{hrs}$ at $37^{\circ} \mathrm{C}$ with or without deferoxamine $(5 \mathrm{mM})$. Generation of hydroxyl radicals by $\mathrm{PM}$ was studied in the presence of hydrogen peroxide and the spintrap DMPO. Briefly, $50 \mu \mathrm{l}$ of the particle suspension or PMsup was mixed with $50 \mu \mathrm{l} \mathrm{H} \mathrm{O}_{2}(0.5 \mathrm{M}$ in PBS), and $100 \mu \mathrm{l}$ DMPO (0.05 $\mathrm{M}$ in water). The mixture was incubated and shaken continuously for $15 \mathrm{~min}$. at $37^{\circ} \mathrm{C}$ and subsequently filtered through a $0.2 \mu \mathrm{m}$ filter (Sartorius). The clear filtrate was transferred to a $100 \mu \mathrm{l}$ glass capillary and was measured with a Miniscope ESR spectrometer (Magnettech, Berlin, Germany). As a negative control a mixture of water (or deferoxamine solution), $\mathrm{H}_{2} \mathrm{O}_{2}$ and DMPO was used. The ESR-spectra were recorded at room temperature using the following instrumental conditions: Magnetic field: $3360 \mathrm{G}$, sweep width: $100 \mathrm{G}$, scan time: $30 \mathrm{sec}$, number of scans: 3, modulation amplitude: $1.975 \mathrm{G}$, reciever gain: $10^{5}$, time-constant: 0.00 .

\section{Exposure of cells to PM}

The immortalised rat lung epithelial cell line RLE was used (Driscoll et al., 1995). Cells (passage 40-50) were seeded in 4-Chamber Culture slides (Falcon). At $80 \%$ confluency, medium was discarded, cells were washed with HBSS and PM-sup was added at a concentration equivalent to a particle concentration of $0.5 \mathrm{mg} / \mathrm{ml}$. Cells were incubated for $4 \mathrm{~h}$ at $37^{\circ} \mathrm{C}$. In some experiments deferoxamine $(1 \mathrm{mM})$, an iron chelator, was used. The cytotoxicity of PM-sup and deferoxamine was tested by the MTT colorimetric assay according to Mosmann (1983) and was described previously (Borm et al., 1997).

\section{8-Hydroxydeoxyguanosine measurement}

After incubation, chambers were removed and slides containing the cells were washed in PBS. 8-OHdG was determined using an immunocytochemical method (Knaapen et al., 1999) with slight modifications. Cells were fixed in $100 \%$ acetone $\left(5 \mathrm{~min} .,-20^{\circ} \mathrm{C}\right)$, and $8-\mathrm{OHdG}$ was detected using a monoclonal antibody (N45.1, Toyokuni et al., 1997). Subsequently, staining was developed using an $\mathrm{ABC}$ kit (Vectastain, Vector Laboratories, USA) with DAB as substrate. Slides were dehydrated and mounted using Depex (Boehringer, Germany). Staining of $8-\mathrm{OHdG}$ was visualised and quantification of $8-\mathrm{OHdG}$ was done using a software analysis system (Soft Imaging System). Briefly, of each sample three pictures containing a total number of at least 1,000 cells were made at $10 \times 5$ magnification and the total staining intensity of the cells present on the photographs was measured and divided by the total number of counted cells. The relative staining intensity was expressed as $\%$ of control. 


\section{Results}

\section{Characterisation of PM}

Analysis of the clear supernatant obtained after centrifugation $(10,000 \mathrm{~g}, 5 \mathrm{~min})$ indicated the presence of agglomerates of ultrafine particles (Figure 1). A blank filter was treated the same way and cellulose polymers were observed in the supernatant. EDX analysis of the elemental content of the large (centrifugeable) particle agglomerates showed an elemental profile which was characterised by $\mathrm{S}, \mathrm{Ca}, \mathrm{Cr}, \mathrm{Zn}$, and $\mathrm{Fe}$ with $\mathrm{Fe}$ being the predominant element. Analysis of the (ultrafine) particles present in the supernatant showed a totally different profile: only minor traces of Fe were detectable and compared with the centrifugeable particles, $\mathrm{Ca}$ was the most predominant element in the particles present is this fraction (data not shown). The supernatant obtained after centrifugation was analysed for the presence of soluble metals using AAS and $\mathrm{Fe}(253 \mu \mathrm{g} / \mathrm{g}), \mathrm{V}(14.7 \mu \mathrm{g} / \mathrm{g})$ and $\mathrm{Ni}(76.0 \mu \mathrm{g} / \mathrm{g}$ insoluble PM) were detected.

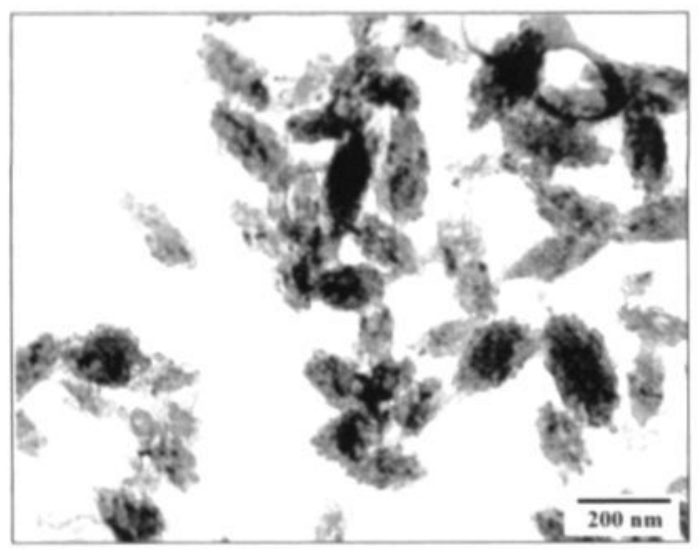

Figure 1. Micrograph of particles present in the PM supernatant. PM suspensions ( $3 \mathrm{mg} \mathrm{ml}$ ) were centrifuged for $5 \mathrm{~min}$ at $10,000 \mathrm{~g}$ and 100 $\mu \mathrm{l}$ of the supernatant was used for analysis by Scanning Transmission electronic microscopy

Free radical activity of $P M$

Both PM and PM-sup induced a significant and similar depletion of supercoiled DNA $(p<0.001)$. Depletion of supercoiled plasmid DNA by PM-sup was inhibited with $60 \%$ by addition of the hydroxyl radical scavenger mannitol $(5 \mathrm{mM})(\mathrm{p}<0.001)$, suggesting a role for these reactive oxygen species (ROS) in the DNA-damaging effect of PM (Figure 2). A blank filter was analysed in the same way and showed no free radical activity. Because the plasmid assay only indirectly indicates the role of hydroxyl radicals, ESR analysis was used to further identify PM-generated hydroxyl radicals in solution. Figure 3 shows representative ESR signals and clearly indicates that, in the presence of $\mathrm{H}_{2} \mathrm{O}_{2}$ and the spintrap DMPO, hydroxyl radicals were generated at the same level by PM as well as PM-sup. In order to investigate the role of iron in this process, deferoxamine $(5 \mathrm{mM})$ was added. This resulted in a total abrogation of the DMPO-OH signal (Figure 3). 


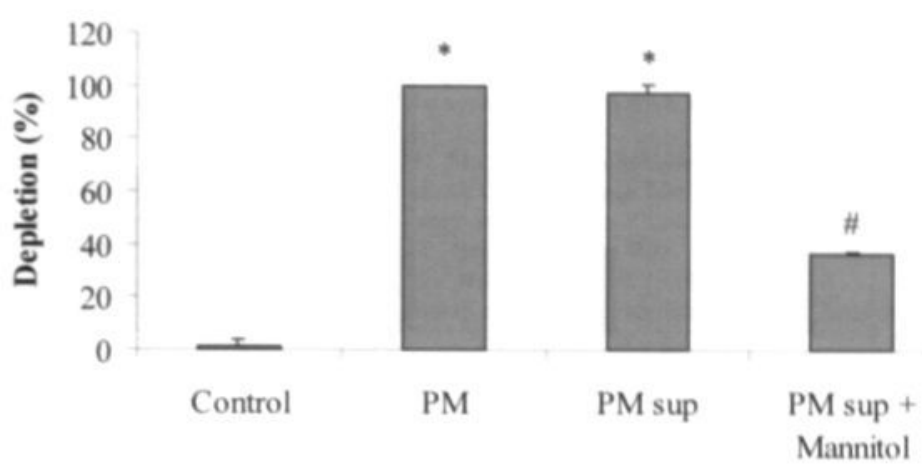

Figure 2. Depletion of supercoiled DNA after incubation with PM. PM (suspensions) or PM supernatant (PM sup) were incubated for $4 \mathrm{~h}$ with $\Phi$ X174RF-DNA $(\mathrm{n}=3)$.

- Significantly different from control (p<0.001), " Significantly different from PM and PM supernatant (p<0.001)

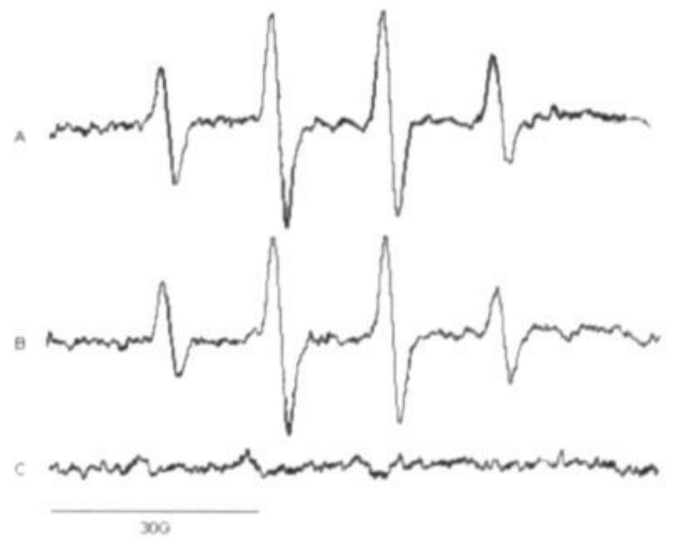

Figure 3. Representative DMPO-OH signals of A) PM supernatant, B) PM particle suspension and C) PM supernatant incubated with deferoxamine $(5 \mathrm{mM}, 3 \mathrm{hrs})$. ESR spectra were recorded after co-incubating $\left(15 \mathrm{~min}, 37^{\circ} \mathrm{C}\right) 50 \mu \mathrm{l}$ particle suspension or supernatant with $50 \mu \mathrm{H}_{2} \mathrm{O}_{2}(0.5 \mathrm{M})$ and $100 \mu \mathrm{I} \mathrm{DMPO}(0.05 \mathrm{M})$.

\section{Induction of 8-OHdG in RLE cells}

To evaluate cellular oxidative DNA damage, RLE cells were exposed to PM-sup for 4 hrs and 8-OHdG was analysed on a single cell level using an immunohistochemical staining. As shown in Figure 4, 8-OHdG levels were increased more than 2-fold as compared to control incubations $(209 \%, \mathrm{p}<0.01)$. To determine the role of soluble iron, RLE cells were incubated under the same conditions in the presence of the iron chelator deferoxamine $(1 \mathrm{mM})$. This resulted in a significant reduction of 8 -OHdG levels ( $130 \%$ of controls compared to $209 \%$ for PM without deferoxamine, $\mathrm{p}<0.01$ ). Deferoxamine alone had no significant effect on the 8OHdG levels in RLE cells. 


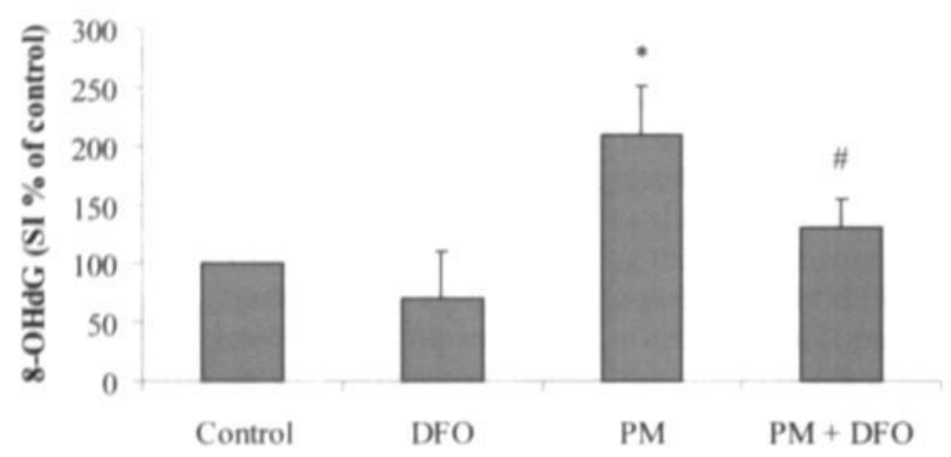

Figure 4. Induction of $8-$ OHdG in RI.F cells incubated (4 hrs) with PM-supernatant $(\mathrm{n}=6)$. Deferoxamine (DFO, $1 \mathrm{mM}$ ) was used to chelate iron. $8-0 \mathrm{HdG}$ was analysed using immunohistochemistry and is expressed as relative staining intensity (SI, \% of control).

- Significantly different from control (p-0.01), " Significantly different from PM (p<0.01).

\section{Discussion}

In this study we showed that the highly reactive hydroxyl radical is generated by particulate matter (PM) and that this radical activity was mainly present in the fraction that was not centrifugeable. We also showed that this fraction induced significant oxidative DNA damage in lung type II cells. Both the production of hydroxyl radicals and the induction of the ${ }^{\circ} \mathrm{OH}-$ specific DNA lesion $8-\mathrm{OHdG}$ were iron dependent since it could be blocked by adding the iron chelator deferoxamine. Many of the biological effects of PM are thought to be ROSrelated (Seaton et al., 1995). However, hardly any studies have been reported that investigated the role of ROS in oxidative DNA damage induced by PM.

Previously, we evaluated the induction of $8-\mathrm{OHdG}$ in RLE cells by immunocytochemical analysis (ICC) as well as by quantitative HPLC (Knaapen et al., 1999). In the present study we used the semi-quantitative ICC, which allowed the use of small sample amounts $(<1 \mathrm{mg})$, usually obtained in ambient air sampling. Since both oxidative DNA damage and ESR-detected hydroxyl radical formation were reduced by deferoxamine, we suggest that soluble iron is responsible for these effects. Previous studies on PM (Gilmour et al., 1996; Smith et al., 1997) and coal fly ashes (van Maanen et al., 1999; Smith et al., 1998) have described iron release from small particles and linked these events to intracellular ferritin induction. We hypothesise that the iron binding capacity of target cells is overwhelmed during PM exposure. Together with the induction of oxidative stress in the cell this may lead to a local Fenton-driven formation of the reactive $\mathrm{OH}$-radical. However, although hydroxyl radical formation and DNA damage seem to be mainly mediated by soluble iron, a role of ultrafine particles still present in the PM-sup cannot be excluded. We demonstrated that these uncentrifugeable particles were low in iron, but they still might contribute to cellular events such as oxidative stress (Donaldson et al., 1998). Further animal or epidemiological studies are needed to investigate whether PM really poses a genotoxic risk following inhalation.

\section{References}

Borm PJA, Knaapen AM. Schins RPF. Godschalk RWI. Van Schooten FJ. Neutrophils amplify the formation of DNAadducts by benrolalpyrene in lung target cells. Emviron Hoalth Perspext 105 (suppl 5): 1089-1093, 1997. 
Costa DL. Dreher KL. Bioavailable transition metals in particulate matter mediate cardiopulmonary injury in healthy and compromized animal models. Environ Health Perspect 105 (suppl 5): 1053-1060, 1997.

Donaldson K, Brown DM, Mitchell C, Dineva M, Beswick PH, Gilmour P, MacNee W. Free radical activity of PMI0; Iron mediated generation of hydroxyl radicals. Emviron Health Perspect 105 (suppl 5): 1285-1289, 1997.

Donaldson K, Li XY, MacNee W. Ultrafine (nanometre) particle mediated lung injury. J Aerosol Sci 29: 553-560, 1998.

Driscoll KE, Carter JM, lype PT, Kumari HL. Crosby L., Aardema MJ, Isfort RJ, Cody D, Chestnut MH, Burns J., Le Boeuf RA Establishment of immortalized alveolar type II cell lines from adult rat lungs. In Vitro Cell Dev Biol 30: 516. $527,1995$.

Gilmour PS, Brown DM, Lindsday TG, Beswick PH, MacNee W, Donaldson K. Adverse health effects of PMI0 particles: involvement of iron in generation of hydroxyl radical. Occup Environ Med 53: 817-822, 1996.

Halliwell B, and Gutteridge JM. Free radicals in biology and medicine, $2^{\text {nd }}$ ed, Clarendon Press, Oxford, 1989.

Knaapen AM, Seiler F, Schilderman PAEL, Nehls P, Bruch J, Schins RPF, Borm PJA. Neutrophils cause oxidative DNA damage in alveolar epithelial cells. Free Radic Biol Med 27: 234-240, 1999.

Mosmann T. Rapid colorimetric assay for cellular growth and survival: application to proliferation and cytotoxicity assays. $J$ Immunol Meth 65: 516-527, 1983.

Pope CA, Bates DV, Raizenne ME Health effects of particulate air-pollution: Time for reassessment? Emviron Healıh Perspect 103: 472-480, 1995.

Seaton A, MacNee W, Donaldson K, Godden D. Particulate air pollution and acute health effects. Lancet 345: 176-178, 1995.

Smith KR, Aust AE. Mobilization of iron from urban particulates leads to generation of reactive oxygen species in vitro and induction of ferritin synthesis in human lung epithelial cells. Chem Res Toxicol 10: 828-834, 1997.

Smith KR, Veranth JM, Lighty JS, Aust AE. Mobilization of iron from coal fly ash was dependent upon the particle size and the source of coal. Chem Res Toxicol I1: 1494-1500, 1998.

Toyokuni S, Tanaka T, Hattori Y, Nishiyama Y, Yoshida A, Uchida K, Hiai H, Ochi H, Osawa T. Quantitative immunohistochemical determination of 8 -hydroxy- $2^{\circ}$-deoxyguanosine by a monoclonal antibody N45.1: Its application to ferric nitrolotriacetate-induced renal carcinogenesis model. Lab Imvestig 76: 365-374, 1997.

Van Maanen JMS, Borm PJA, Knaapen AM, van Herwijnen M, Schilderman PAEL, Smith KR, Aust AE, Tomatis M, Fubini B. In vitro effects of coal fly ashes: Hydroxyl radical generation, iron release, and DNA damage and toxicity in rat lung epithelial cells. Inhal Toxicol 11: 1123-1141, 1999. 



\title{
Chapter 3
}

\section{Soluble metals as well as the insoluble particle fraction are involved in cellular DNA damage induced by particulate matter}

\author{
Ad M Knaapen, Tingming Shi, Paul JA Borm, Roel PF Schins
}

Department of Fibre \& Particle Toxicology. Medical Institute of Environmental Hygiene.

Auf 'm Hennekamp 50, 40225 Düsseldorf, Germany

\begin{abstract}
Exposure to ambient particulate matter has been reported to be associated with increased rates of lung cancer. Previously we showed that total suspended particulate matter (PM) induces oxidative DNA damage in epithelial lung cells. The aim of the present study was to further investigate the mechanism of PM-induced DNA damage in which soluble iron-mediated hydroxyl radical $(\mathrm{OH})$ formation is thought to play a crucial role. Using electron spin resonance (ESR) we showed that PM suspensions as well as their particle-free, water-soluble fractions can generate ${ }^{\circ} \mathrm{OH}$ in the presence of hydrogen peroxide $\left(\mathrm{H}_{2} \mathrm{O}_{2}\right)$, an effect which was abrogated by both deferoxamine and catalase. In addition, PM was also found to induce the 'OH-specific DNA lesion 8-hydroxydeoxyguanosine (8-OHdG) in the presence of $\mathrm{H}_{2} \mathrm{O}_{2}$ as assessed by dot-blot analysis of calf thymus DNA using an $8-\mathrm{OHdG}$ antibody. In human alveolar epithelial cells (A549), both PM suspensions and the particle-free soluble fraction elicited the formation of DNA strand breaks (comet-assay). Unlike the acellular DNA assays, in epithelial cells the DNA-damaging capacity of the particle suspensions appeared to be stronger than that of their corresponding particle-free supernatants. In conclusion, our findings demonstrate that the water-soluble fraction of PM elicits DNA damage via transition metal-dependent ${ }^{\circ} \mathrm{OH}$ formation, implicating an important role of $\mathrm{H}_{2} \mathrm{O}_{2}$. Moreover, our data suggest that direct 'particle' effects contribute to the genotoxic hazard of ambient particulate matter in lung target cells.
\end{abstract}

Based on: Molecular and Cellular Biochemistry 234/235: 317-326, 2002. 


\section{Introduction}

Epidemiological studies have demonstrated a significant association between exposures to ambient particulate matter (PM) and the incidence of acute mortality and morbidity due to cardiovascular or pulmonary complications $[1,2]$. Additionally, PM has also been associated with increased rates of lung cancer $[2,3]$. However, the mechanism of PM-induced carcinogenesis is not clear. PM is a complex mixture of aggregates of organic and inorganic compounds such as carbonaceous material, polyaromatic hydrocarbons, metals, salts and endotoxins. Studies investigating the possible mechanisms of carcinogenicity induced by PM, have mainly focused on its genotoxic properties. For instance, several studies concentrated on the role of organic extractable mutagens such as PAH's [e.g. 4-6], whereas others investigated the genotoxic effects of transition metals because of their specific relation with respiratory tract carcinogenesis [7].

Apart from the genotoxic effects of several individual PM constituents, it is now generally accepted that the ability of PM to generate reactive oxygen species (ROS) plays a pivotal role in PM-induced adverse health effects [8-11]. For instance, we and others have demonstrated a clear relation between PM-induced DNA damage and its ability to generate $\operatorname{ROS}[12-14]$. Among these ROS, the hydroxyl radical $\left({ }^{\circ} \mathrm{OH}\right)$ is of greatest concern, because it

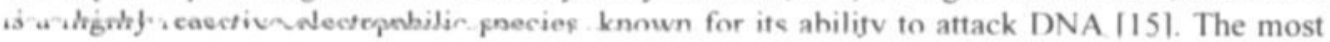
common way for hydroxyl radicals to be generated is via the Fenton reaction, which involves the reduction of hydrogen peroxide by a transition metal ion [16,17]. Transition metals such as $\mathrm{Fe}$ and $\mathrm{Cu}$ are abundantly present in PM [18], and have been shown to be potent inducers of oxidative DNA damage [19-21]. Indeed, previously we showed that induction of the ${ }^{\circ} \mathrm{OH}-$ specific DNA lesion 8-hydroxydeoxyguanosine (8-OHdG) by PM or coal fly ash was clearly related to the ability of these particles to generate ${ }^{\circ} \mathrm{OH}$ via an iron-dependent Fenton reaction $[22,12]$.

However, studies investigating genotoxic effects of water-soluble factors, such as transition metals, fail to evaluate PM as an entirety and thus fail to evaluate possible effects of the insoluble particulate fraction. PM is known to be comprised mostly, in terms of particle numbers, of ultrafine particles $(<100 \mathrm{~nm})$, and it is this ultrafine fraction which is reported to play a major role in the observed association between PM exposure and adverse health effects $[23,24]$. Although poorly soluble particles such as quartz and carbon black have been shown to cause DNA damage [25-27], the specific role of the insoluble particle fraction in the genotoxicity of PM is still poorly described. Therefore, the aim of the present study was to expand our earlier work and to investigate the mechanism of PM-induced oxidative DNA damage more closely. More specifically, we hypothesise that the insoluble particle core contributes to a previously described mechanism of PM-induced DNA damage in which soluble iron-dependent ${ }^{\circ} \mathrm{OH}$ formation is thought to play a central role [12]. Therefore, we investigated the ability of both the water-soluble and insoluble fractions of $\mathrm{PM}$ to induce $\mathrm{OH}$ and whether these were able to induce the ${ }^{\circ} \mathrm{OH}$-specific DNA lesion 8-OHdG in naked DNA upon direct exposure to PM. To investigate the implications of these observations for cellular DNA, human lung epithelial cells were exposed to PM and DNA-strand breakage was analysed on a single cell level using the comet assay.

\section{Materials and Methods}

\section{Chemicals}

Albumin, deferoxamine mesylate (DFO), diaminobenzidine-tetrahydrochloride (DAB), 5.5dimethyl-1-pyrroline-n-oxide (DMPO), Hanks' balanced salt solution (HBSS), ethidium bromide, Dulbecco's modified eagle's medium (DMEM). Hepes buffer, fetal calf serum. 
horse radish peroxidase, phenol red, phosphate buffered saline (PBS), phorbol myristate acetate (PMA), and trypsin/EDTA, were obtained from Sigma (St. Louis, MO). Hydrogen peroxide $\left(\mathrm{H}_{2} \mathrm{O}_{2}\right)$ was purchased from Fluka (Seelze, Germany). Catalase was obtained from Roche (Mannheim, Germany). Calf thymus DNA and RNAse were obtained from Boehringer (Mannheim, Germany). For electron spin resonance experiments deionised water was used (Millipore).

\section{Preparation and characterisation of $P M$}

PM was sampled in Duisburg Germany (1993-1995) on nitrocellulose filters (Pore size: $3 \mu \mathrm{m}$, Sartorius; Göttingen, Germany) using a high volume sampler (HVS 150, Ströhlein Instruments, Germany). PM suspensions were prepared by cutting $45 \mathrm{~cm}^{2}$ of the filter, immersed in deionised water $(5 \mathrm{ml})$, shaking $(5 \mathrm{~min})$ and subsequently sonication in a waterbath (Sonorex TK52; 60 Watt, $35 \mathrm{kHz}, 5 \mathrm{~min}$ ). Because the obtained particle suspension was partly contaminated by small filter fibres (5-10\% on mass basis) a blank filter was treated the same way and was used as a control in all experiments. The final particle concentration of both PM and blank filter preparations was estimated by comparative turbidometry at $405 \mathrm{~nm}$ using carbon black as a standard (Huber 990, $260 \mathrm{~nm}$ ). Although part of the PM is water-soluble this method was used to prepare suspensions with equal particle concentrations for all experiments. Previous comparative experiments using gravimetric analysis of PM before and after filter extraction confirmed the correlation between turbidometry and gravimetric analysis. To obtain supernatants, the PM suspensions were centrifuged for 5 minutes at $13,000 \mathrm{~g}$. Because our previous work demonstrated that the supernatant still contained ultrafine particles [12], in some experiments PM suspensions were also filtered through a $0.1 \mu \mathrm{m}$ filter (Acrodisc $25 \mathrm{~mm}$ syringe filter, Pall Gelman Laboratory, Ann Arbor, USA). No ultrafine particles were observed in these filtrates (Data not shown). Particles were visualised using Scanning/Transmission Electron Microscopy (STEM, Philips $\mathrm{CM} 12$ ). Energy dispersive X-ray analysis (EDX) of the elemental content of the large (centrifugeable) particle agglomerates present in the suspension showed an elemental profile which was characterised by $\mathrm{S}, \mathrm{Ca}, \mathrm{Cr}, \mathrm{Zn}$, and $\mathrm{Fe}$. The predominant element in the sample was Fe. The soluble fraction of PM was analysed for the presence of soluble metals using atomic absorption spectrometry (AAS) and Fe $(253 \mu \mathrm{g} / \mathrm{g}), \mathrm{V}(14.7 \mu \mathrm{g} / \mathrm{g})$ and $\mathrm{Ni}(76.0 \mu \mathrm{g} / \mathrm{g}$ insoluble PM) were detected. Although total suspended particulate matter, used in the present study contains non-respirable particles, approximately $70 \%$ of PM is reported to consist of respirable particles [28]. Further details have been previously described [12].

\section{Measurement of hydroxyl radicals using electron spin resonance}

Generation of ${ }^{\circ} \mathrm{OH}$ by $\mathrm{PM}$-preparations was investigated in the presence of hydrogen peroxide and the spin trap 5,5-dimethyl-1-pyrroline- $\mathrm{N}$-oxide (DMPO) [29]. Prior to use, the spin trap was purified with active coal. Therefore, DMPO was dissolved in deionised water and active coal was added $(30 \mathrm{mg} / \mathrm{ml})$. The suspension was shaken continuously, incubated for $20 \mathrm{~min}$. at $35^{\circ} \mathrm{C}$, and subsequently centrifuged $(2000 \mathrm{~g}, 10 \mathrm{~min})$. This procedure was repeated once and the clear supernatant was filtered $(0.45 \mu \mathrm{m})$. The final DMPO concentration was measured using spectrophotometry $(234 \mathrm{~nm})$, and aliquots were stored at $-20^{\circ} \mathrm{C}$. For DMPO$\mathrm{OH}$ measurement, $50 \mu \mathrm{l}$ of the PM suspension $(2 \mathrm{mg} / \mathrm{ml})$, its supernatant, or their respective filtrates $(0.1 \mu \mathrm{m})$ were mixed with $100 \mu \mathrm{l}$ DMPO $(0.05 \mathrm{M}$ in PBS). The reaction was started by addition of $\mathrm{H}_{2} \mathrm{O}_{2}(50 \mu \mathrm{l}$ of $0.5 \mathrm{M}$ in PBS). The mixture was incubated and shaken continuously for $10 \mathrm{~min}$. at $37^{\circ} \mathrm{C}$ and subsequently filtered through a $0.1 \mu \mathrm{m}$ filter. The clear filtrate was then transferred to a $100 \mu \mathrm{l}$ glass capillary and was measured with a Miniscope MS 100 ESR spectrometer (Magnettech, Berlin, Germany). To investigate the role of iron in these experiments, particle suspensions $(0.5 \mathrm{mg} / \mathrm{ml})$ were mixed with $50 \mu l$ deferoxamine 
mesylate (0-3.2 mM), incubated for 10 minutes at $37^{\circ} \mathrm{C}$, followed by addition of DMPO and $\mathrm{H}_{2} \mathrm{O}_{2}$. The specific role of $\mathrm{H}_{2} \mathrm{O}_{2}$ was investigated by mixing $P M$ suspensions with increasing concentrations of $\mathrm{H}_{2} \mathrm{O}_{2}(0-1000 \mu \mathrm{M})$, or by the addition of catalase $(0-1000 \mathrm{U} / \mathrm{ml})$ to a mixture of PM, DMPO and $\mathrm{H}_{2} \mathrm{O}_{2}(0.125 \mathrm{M})$. Inactivated catalase $\left(1000 \mathrm{U} / \mathrm{ml}, 10 \mathrm{~min}, 95^{\circ} \mathrm{C}\right)$ was used to check for non-specific protein effects. As negative control, a mixture of water (or deferoxamine or catalase), $\mathrm{H}_{2} \mathrm{O}_{2}$ and DMPO was used, whereas a mixture of $\mathrm{FeSO}_{4}(1 \mathrm{mM}$ in deionised water $), \mathrm{H}_{2} \mathrm{O}_{2}(0.125 \mathrm{M})$ and DMPO was used as a positive control. The ESRspectra were recorded at room temperature using the following instrumental conditions; Magnetic field: $3360 \mathrm{G}$, sweep width: $100 \mathrm{G}$, scan time: $30 \mathrm{sec}$, number of scans: 3 , modulation amplitude: $1.8 \mathrm{G}$, reciever gain: 1000 , microwave frequency: $9.9 \mathrm{GHz}$, power attenuation: $6 \mathrm{~dB}$. Quantification was done by accumulation of 3 different spectra, each averaging 3 different scans. "OH formation was then quantified by measuring the amplitude of the 4 peaks of the 1:2:2:1 quartet pattern, which is specific of the DMPO-OH signal. Outcomes are expressed as total amplitude in arbitrary units.

\section{Dot-blot assay for detection of 8-Hydroxydeoxyguanosine}

Induction of the $\mathrm{OH}$-specific DNA lesion 8-hydroxydeoxyguanosine (8-OHdG) by PM in isolated calf thymus DNA was estimated via a dot-blot assay that we have developed, based on a method as described by Musarrat et al [30]. Freshly prepared suspensions of PM $(50 \mu \mathrm{l}$ of $1.6 \mathrm{mg} / \mathrm{ml}$ in PBS) were incubated with $50 \mu \mathrm{g}$ of calf thymus DNA dissolved in Tris- $\mathrm{HCl}$ ( $10 \mathrm{mM}, \mathrm{pH} 8.0)$ and $\mathrm{H}_{2} \mathrm{O}_{2}(1 \mathrm{mM})$, in a final volume of $500 \mu \mathrm{l}$. In each experiment, DNA incubated without $\mathrm{PM}$ and $\mathrm{H}_{2} \mathrm{O}_{2}$, as well as DNA incubated with $0.1 \mathrm{mM} \mathrm{FeSO}_{4}$ and $1 \mathrm{mM}$ hydrogen peroxide were included as negative and positive controls respectively. Samples were incubated in the dark for 60 minutes at $37^{\circ} \mathrm{C}$ in a shaking water bath. At the end of each incubation, samples were immediately centrifuged $(6000 \mathrm{rpm}, 5 \mathrm{~min})$, and $400 \mu \mathrm{l}$ of the supernatant was transferred to a fresh tube. The DNA was precipitated by the addition of $1 / 10$ vol. $\mathrm{NaAc}(1.5 \mathrm{M}, \mathrm{pH} 6.0)$ and $2 \times 100 \%$ ice-cold ethanol. Precipitated DNA was then washed twice using $70 \%$ ethanol $(13,000 \mathrm{rpm}, 5 \mathrm{~min})$, dried in dark, dissolved in $30 \mu \mathrm{l}$ of Tris- $\mathrm{HCl}$ buffer and stored overnight at $4^{\circ} \mathrm{C}$. On the next day, DNA concentrations were determined spectrophotometrically and the samples were diluted to a final concentration of $2.56 \mu \mathrm{g} / \mathrm{ml}$ in 20xSSC. Of each sample, replicate 2 -fold dilutions were blotted on a nitrocellulosemembrane using a dot-blot apparatus. To each blot, both negative and positive controls are added. The DNA was cross-linked by baking the membrane for $90 \mathrm{~min}$ in a pre-warmed oven at $80^{\circ} \mathrm{C}$. Blocking of the membrane was performed overnight using casein. Immunostaining of $8-\mathrm{OHdG}$ was performed using the $\mathrm{N} 45.1$ monoclonal antibody [31] and the Vectastain$\mathrm{ABC}$ kit with diaminobenzidine-staining according to the recommended protocol (Vector Laboratories, Burlingame, CA). The blots were analysed by computer-assisted densitometry scanning (Bio Rad, Gel Doc 2000, Milan, Italy), and expressed relatively to the density of the negative controls.

\section{Hydrogen peroxide measurement}

$\mathrm{H}_{2} \mathrm{O}_{2}$ formation by human neutrophils exposed to $\mathrm{PM}$ was performed according to the method described by Pick and Keisari [32]. Human peripheral blood neutrophils ( $1 \times 10^{6}$ cells $\left./ \mathrm{ml}\right)$ were isolated as previously described [33]. plated in 24-well tissue culture plates, and subsequently exposed to PM suspensions $(0-100 \mu \mathrm{g} / \mathrm{ml})$ in HBSS, containing $8.5 \mathrm{U} / \mathrm{ml}$ horseradish peroxidase and $0.28 \mathrm{mM}$ phenol red. After incubation ( $1 \mathrm{~h}$ ), cells were centrifuged, and $5 \mu \mathrm{l}$ of $1 \mathrm{M} \mathrm{NaOH}$ was added to $500 \mu \mathrm{l}$ of the supernatant. Absorption was measured at $610 \mathrm{~nm}$ using a spectrophotometer (Beckman, Fullerton, $\mathrm{CA}$ ) and final concentrations were calculated from a standard curve of $\mathrm{H}_{2} \mathrm{O}_{2}$. PMA $(100 \mathrm{ng} / \mathrm{ml})$ was used as a positive control. 


\section{Exposure of human type II lung cells to particulate matter}

Experiments were performed with A549 cells (American Type Culture Collection). These cells have structural and biochemical characteristics of human type II cells, are known to ingest particles [34], and have been used by several research groups to study DNA damage induced by asbestos fibres or ambient particulate matter [35,27]. Cells were grown in DMEM supplemented with $10 \%$ heat inactivated foetal calf serum, L-glutamine, and $30 \mathrm{IU} / \mathrm{ml}$ penicillin-streptomycin at $37^{\circ} \mathrm{C}$ and $5 \% \mathrm{CO}_{2}$. For experiments, cells were trypsinised at confluency, seeded into $60 \mathrm{~mm}$ culture dishes, and grown until confluency. Cells were then washed 2 times with HBSS and treated with PM suspensions or their particle-free filtrates. Particles present in the resuspended pellet, obtained after centrifugation, were not tested in this cellular assay, as electron microscopy analysis indicated that this process dramatically changed particle agglomeration and distribution (not shown). PM suspensions were prepared as described before, although here PM-filter pieces were suspended in HBSS in stead of water. The (diluted) suspensions were added to the dishes in a final volume of $2.5 \mathrm{ml} /$ dish. Final concentrations used were 5 and $20 \mu \mathrm{g} / \mathrm{cm}^{2}$ (resp. 40 and $200 \mu \mathrm{g} / \mathrm{ml}$ ). Cells were incubated for $3 \mathrm{~h}$ at $37^{\circ} \mathrm{C}\left(100 \%\right.$ relative humidity, $\left.5 \% \mathrm{CO}_{2}\right)$. In some experiments, deferoxamine (final concentration $0.4 \mathrm{mM}$ ), was used as an iron chelator.

\section{DNA strand break analysis (comet assay)}

DNA strand break formation in A549 cells was determined by the comet-assay [36], according to the guidelines recently proposed by an expert panel [37]. Fully frosted slides were covered with a layer of $0.65 \%$ agarose using a coverslip and stored overnight at $4^{\circ} \mathrm{C}$. A549 cells were harvested from the dishes using trypsin and were then suspended in HBSS. Cytotoxicity in A549 cells caused by exposure procedures and cell processing was evaluated using Trypan Blue dye exclusion. Subsequently, $25 \mu \mathrm{l}$ of the cell suspension $\left(2 \times 10^{6} \mathrm{cells} / \mathrm{ml}\right)$ was mixed with $75 \mu \mathrm{l} 0.5 \%$ low melting point agarose. This mixture was then added to the slides, on top of the first agarose layer using a coverglass. Slides were stored 45 minutes at $4^{\circ} \mathrm{C}$ to allow solidification, and covered with another layer of low melting point agarose ( 100 $\mu \mathrm{l})$. Following solidification for at least 45 minutes at $4^{\circ} \mathrm{C}$, slides were immersed in lysis buffer $(2.5 \mathrm{M} \mathrm{NaCl}, 100 \mathrm{mM}$ EDTA, $10 \mathrm{mM}$ Tris-base, $1 \%$ Sodium Lauryl sarcosinate, $\mathrm{pH}$ $10 ; 10 \%$ DMSO and $1 \%$ Triton X-100 added just before use) and stored overnight at $4^{\circ} \mathrm{C}$. The following day, slides were rinsed with distilled water and placed in an electrophoresis tank filled with ice-cold buffer $(300 \mathrm{mM} \mathrm{NaOH}, 1 \mathrm{mM}$ EDTA, pH 13) for 30 minutes. Electrophoresis was conducted at $300 \mathrm{~mA}$ and $25 \mathrm{~V}$ for 15 minutes. Slides were then neutralised $3 \times 10 \mathrm{~min}$ using neutralisation buffer $(0.4 \mathrm{M}$ Tris, $\mathrm{pH} 7.5)$. All steps described were performed in the dark to prevent additional DNA damage. Slides were stained with ethidium bromide $\left(20 \mu \mathrm{g} / \mathrm{ml}\right.$ in $\left.\mathrm{H}_{2} \mathrm{O}\right)$ and comet appearances were analysed using an Olympus BX60 fluorescence microscope at 1000x magnification. Samples were tested in duplicate within each experiment. On every single slide 50 cells were analysed randomly, and classified into one out of five categories according to tail length $(0,1,2,3,4$, in which $0=$ no tail). For final analysis a 'comet-score' of each individual slide was calculated, according to Collins et al [38]: Comet Score $=$ sum(class 1 cells $+2 x$ class 2 cells $+3 x$ class 3 cells $+4 x$ class 4 cells). Using this formula a minimally damaged sample will have a score of 0 , whereas a maximally damaged sample obtains a comet score of 200 .

\section{Statistical analysis}

Data are expressed as mean $\pm \mathrm{sd}$ (at least 2 independent experiments). Statistical analysis was performed using SPSS v. 10 for Windows. ANOVA (Tukey) was applied to test differences between groups. Differences were considered to be statistically significant when p< 0.05 . 


\title{
Results
}

\section{Hydroxyl radical generation by $P M$}

ESR analysis was used to determine ${ }^{\circ} \mathrm{OH}$ generation by PM. Figure 1 shows representative DMPO-OH signals (1:2:2:1 quartet) and clearly indicates that, in the presence of $\mathrm{H}_{2} \mathrm{O}_{2}$ and the spintrap DMPO, 'OH were generated at the same level by PM suspensions as well as their supernatants or filtrates. When the centrifugable fraction (containing the insoluble fraction) was resuspended in water the ${ }^{\circ} \mathrm{OH}$-generating capacity was reduced. Formation of ${ }^{\circ} \mathrm{OH}$ was not observed when blank filter preparations were tested.
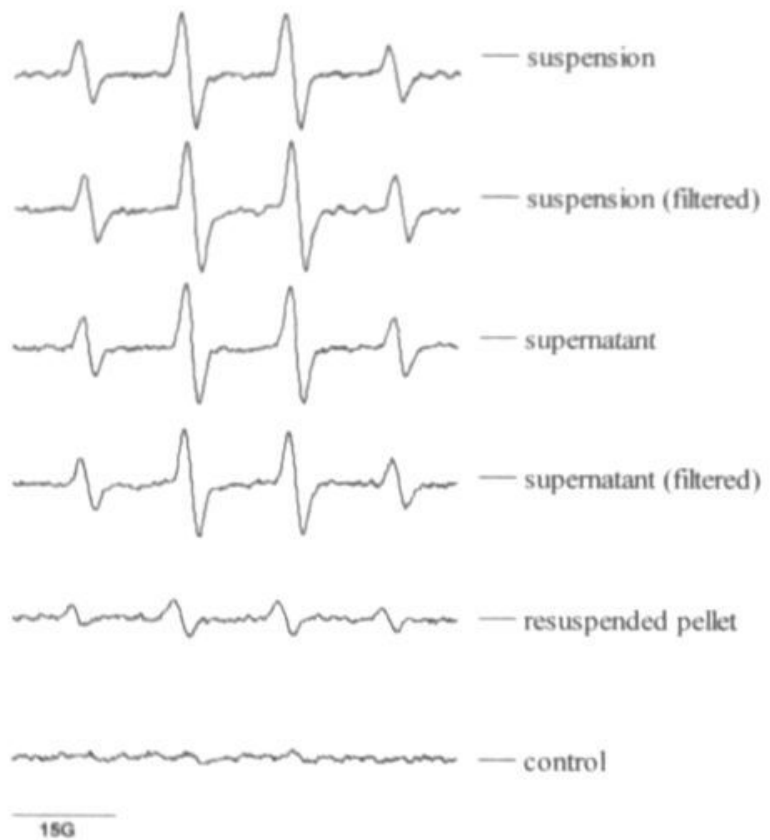

\begin{abstract}
Figure 1. Representative DMPO-OH signals (1:2:2:1 quartet). ESR spectra were recorded after incubation ( $10 \mathrm{~min})$ of a mixture of $\mathrm{PM}(0.5 \mathrm{mg} \mathrm{ml})$, hydrogen peroxide $(0.125 \mathrm{M})$ and the spintrap DMPO (25 mM). Signals of PM suspensions, their supernatants $(13,000 \mathrm{~g})$ or filtrates $(0,1 \mu \mathrm{m})$ are shown. The centrifuged pellet of the insoluble particle fraction was resuspended and measured again (resuspended pellet). No signals were observed when PM was omitted (control).
\end{abstract}

When $\mathrm{H}_{2} \mathrm{O}_{2}$ was omitted in these ESR experiments, minimal amounts of ${ }^{\circ} \mathrm{OH}$ were detected. However, $\mathrm{H}_{2} \mathrm{O}_{2}$ added in $\mu \mathrm{M}$ range, dose dependently enhanced ${ }^{\circ} \mathrm{OH}$ formation (Table 1). Previous data suggested a role of Fenton-driven formation of hydroxyl radicals [12]. which implies the involvement of both transition metals and $\mathrm{H}_{2} \mathrm{O}_{2}$. As iron appeared to be the most prominent transition metal present in PM suspensions, its role was assessed using the iron chelator deferoxamine. Figure $2 \mathrm{a}$ clearly shows that ${ }^{\circ} \mathrm{OH}$ formation was totally inhibited at a deferoxamine concentration of $100 \mu \mathrm{M}$. The importance of $\mathrm{H}_{2} \mathrm{O}_{2}$ in this system was evaluated using catalase (Fig. 2b). Also here a dose-dependent decrease of ${ }^{\circ} \mathrm{OH}$ formation was observed. Heat inactivated catalase $(1000 \mathrm{U} / \mathrm{ml})$ did not affect ${ }^{\circ} \mathrm{OH}$ formation. 
Table 1. Enhancement of ${ }^{\circ} \mathrm{OH}$ formation by $\mathrm{PM}$ in the presence of hydrogen peroxide $\left(\mathrm{H}_{2} \mathrm{O}_{2}\right)$.

\begin{tabular}{cll}
\hline Concentration $\mathrm{H}_{2} \mathrm{O}_{2}(\mu \mathrm{M})$ & DMPO-OH signal $(\%)$ \\
\hline PM & $+0 \mu \mathrm{M}$ & 100 \\
& $+1 \mu \mathrm{M}$ & $114 \pm 15$ \\
& $+10 \mu \mathrm{M}$ & $139 \pm 11^{\bullet}$ \\
& $+100 \mu \mathrm{M}$ & $150 \pm 17^{\bullet}$ \\
& $+1000 \mu \mathrm{M}$ & $191 \pm 7^{* \bullet}$ \\
\end{tabular}

PM $(0.5 \mathrm{mg} / \mathrm{ml})$ was mixed with DMPO $(25 \mathrm{mM})$ and $\mathrm{H}_{2} \mathrm{O}_{2}$, and incubated for $10 \mathrm{~min}\left(37^{\circ} \mathrm{C}\right)$. DMPO-OH signals were quantified as described in the methods section and expressed as $\%$ of control (= $\mathrm{PM}+0 \mu \mathrm{M} \mathrm{H}_{2} \mathrm{O}_{2}$ ). ${ }^{\circ p} 0.05,{ }^{\cdots p} 0.01$ vs. $\mathrm{PM}+0 \mu \mathrm{M} \mathrm{H}_{2} \mathrm{O}_{2}$ (ANOVA, Dunnett).

\section{Formation of 8-hydroxydeoxyguanosine in mude DNA}

To assess the significance of ${ }^{\circ} \mathrm{OH}$ formation by PM in DNA damage we applied a dot-blot method to measure the formation of the ${ }^{\circ} \mathrm{OH}$-specific DNA lesion 8-OHdG. A representative blot containing different incubations is shown in Figure 3. PM-induced formation of 8-OHdG was only observed when $\mathrm{H}_{2} \mathrm{O}_{2}$ was added. Hydrogen peroxide alone did not affect 8-OHdG levels (Fig. 4). Moreover, as for ESR-detected ${ }^{\circ} \mathrm{OH}$ formation, also here no differences were observed between the PM suspension or its supernatant, again indicating the major role of soluble factors present in PM.

A

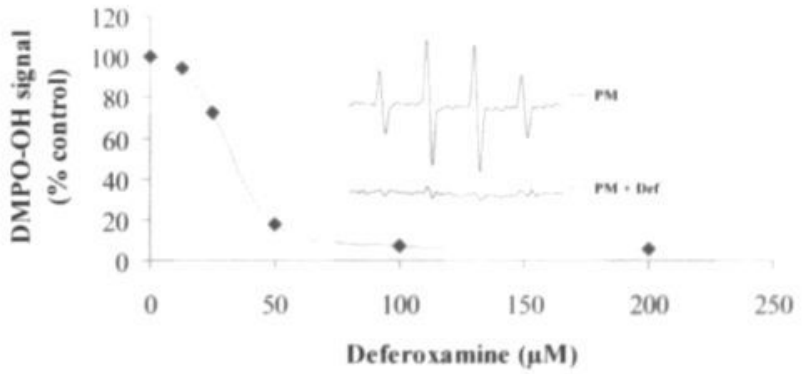

B

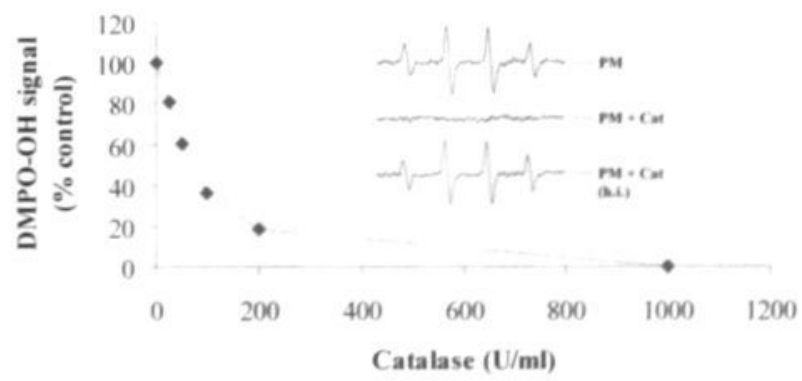

Figure 2. Effects of deferoxamine $(\mathrm{A})$ and catalase (B) on hydroxyl radical formation by PM. PM $(0.5 \mathrm{mg} / \mathrm{ml})$ was mixed with deferoxamine or catalase, hydrogen peroxide $(0.125 \mathrm{M})$ and the spintrap DMPO $(25 \mathrm{mM})$. DMPO-OH signals were quantified as total amplitude of the 4 specific peaks and are expressed as $\%$ of control levels (without deferoxamine or catalase). Insert in A shows representative signals of PM and PM with Deferoxamine $(200 \mu \mathrm{M})$. Heat inactivated (h.i.) catalase (Cat, $1000 \mathrm{U} / \mathrm{ml}$ ) did not inhibit the formation of DMPO-OH (see insert in B). 


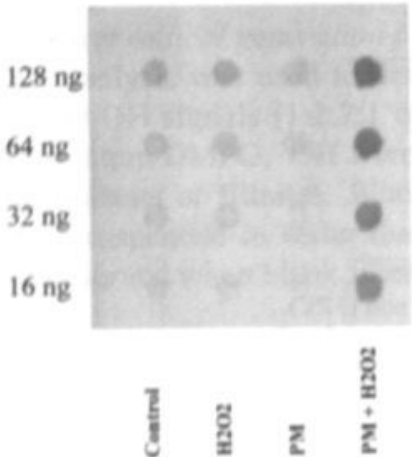

Figure 3. Representative picture of Dotblot analysis of the formation of 8 hydroxydeoxyguanosine $(8-\mathrm{OHdG})$ in calf thymus DNA induced by PM. PM was incubated with DNA either alone or with hydrogen peroxide. Small amounts of DNA were then blotted (16-128 ng), and stained with an antibody against 8-OHdG.

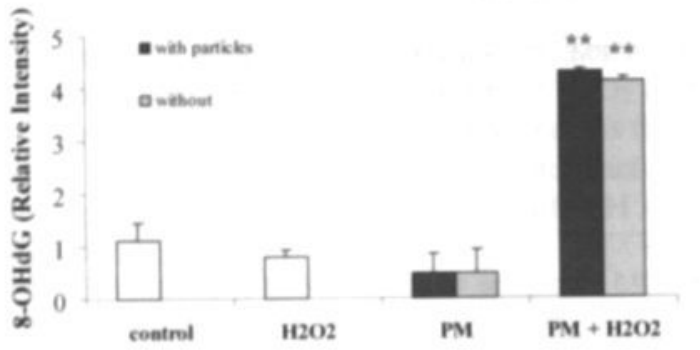

Figure 4. Analysis of 8-hydroxydeoxyguanosine (8OHdG) induction in naked DNA exposed to PM. 8OHdG was analysed using a dot-blot assay. PM was tested as suspension (with particles) or as its filtrate (without particles). Staining intensity of $8-0 \mathrm{HdG}$ was analysed by computer-assisted densitometry scanning. and was expressed as intensity relative to control incubations (no $\mathrm{PM}$ and $\mathrm{H}_{2} \mathrm{O}_{2}$ ). ${ }^{*}$ p $<0.01$ vs. PM

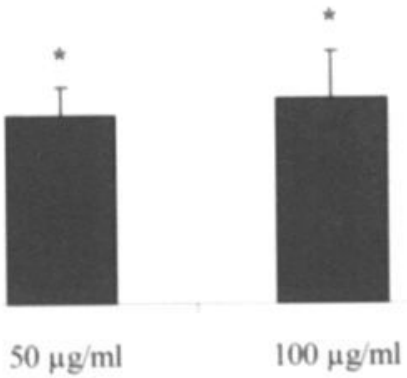

PM concentration

Figure 5. Hydrogen peroxide release by human neutrophils exposed to PM suspensions. Cells were exposed for Ih. Ilydrogen peroxide was measured according to the method described by Pick and Keisari [32]. PMA (100 ng/ml), used as a positive control gave a release of $25.9+3.2 \mu \mathrm{M}$. "p $0.05 \mathrm{vs} .0 \mu \mathrm{g} / \mathrm{ml} \mathrm{PM}$.

\section{Hydrogen peroxide release by neutrophils}

Human neutrophils were exposed to PM suspensions to investigate whether particulate matter was able to activate the oxidative burst of these cells. When neutrophils were exposed for 1 hour to 50 or $100 \mu \mathrm{g} / \mathrm{ml} \mathrm{PM}$, a clear increase of $\mathrm{H}_{2} \mathrm{O}_{2}$ released into the medium was found (Fig. 5). $\mathrm{No}_{2} \mathrm{O}_{2}$ was detected when PM suspensions were incubated without cells.

\section{DNA strand break formation in A549 cells}

Single cell gel electrophoresis (comet assay) was applied to investigate PM-induced DNA strand break formation in A549 cells. Data are shown in Figure 6. A significant increase in DNA strand breakage was only found using the highest concentration $\left(20 \mu \mathrm{g} / \mathrm{cm}^{2}\right)$ of the native PM suspension, whereas this was not observed for its particle-free filtrate, suggesting 
that the insoluble particle fraction contributes to PM-induced DNA damage. To investigate the role of soluble iron, A549 cells were exposed to PM $\left(20 \mu \mathrm{g} / \mathrm{cm}^{2}\right)$ in the presence of the iron chelator deferoxamine (DFO). Deferoxamine alone $(0.4 \mathrm{mM})$ did not affect DNA damage. However, DNA strand breaks induced by both PM suspensions and particle free filtrates was reduced by deferoxamine. All effects were observed in the absence of cytotoxicity, as determined by trypan blue dye exclusion after incubation. Moreover, also blank filter preparations (both suspensions and filtrates) were tested, but no effects were observed (data not shown),

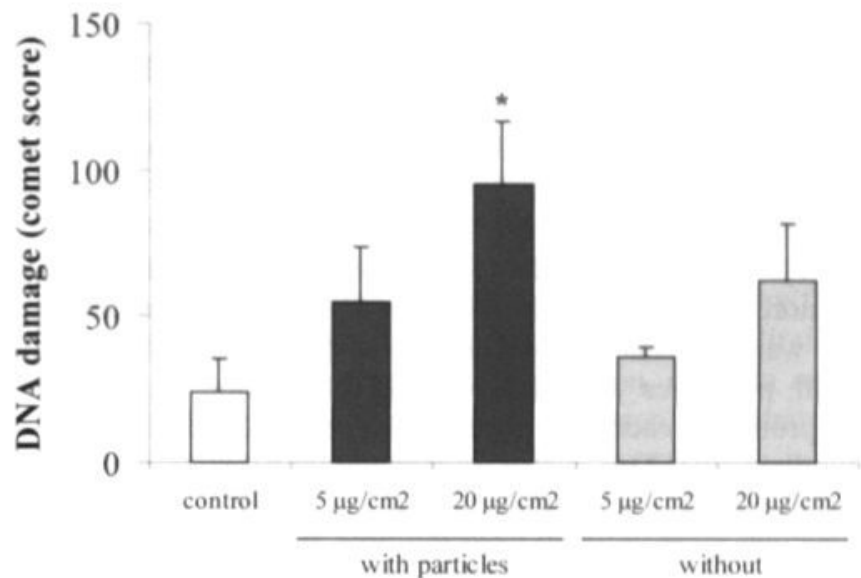

Figure 6. DNA strand breakage in A549 cells exposed to PM. Both PM suspensions (with particles) and PM filtrates (0.I $\mu \mathrm{m}$; without particles) were tested. Cells were incubated for $3 \mathrm{~h}$, and DNA stand break formation was analysed using the comet assay. Strand break formation was analysed by classification of cells into one out of five classes, according to tail length. " $\mathrm{p}<0.05$ vs. control.

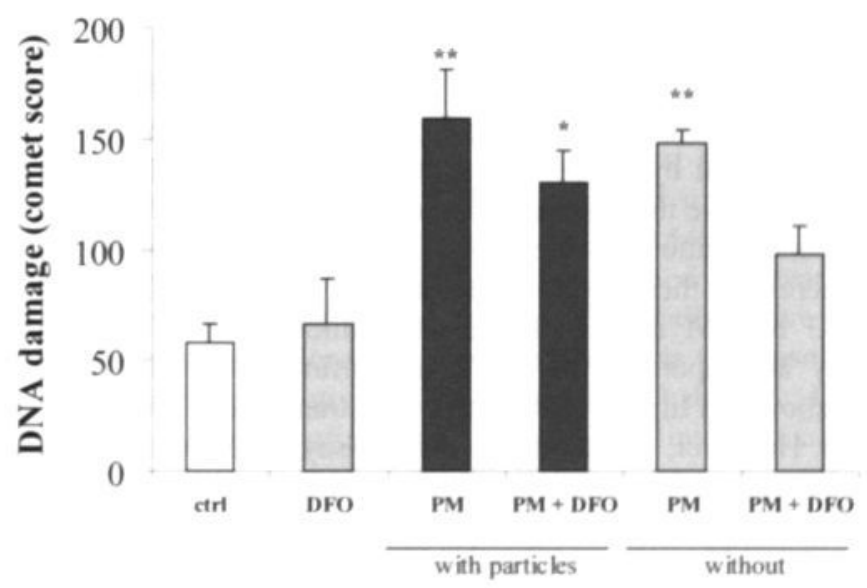

Figure 7. Effect of the iron chelator deferoxamine (DFO) on DNA strand breakage in A549 cells exposed to PM. Both PM suspensions (with particles) and PM filtrates $(0.1 \mu \mathrm{m}$; without particles) were tested. Cells were incubated for $3 \mathrm{~h}$ with or without DFO, and DNA stand break formation was analysed using the comet assay. Strand break formation was analysed by classification of cells into one out of five classes, according to tail length. $*$ p $0.01 . " p<0.05 \mathrm{vs}$. control (ctrl). 


\section{Discussion}

Epidemiological studies have established an association between increased lung cancer rates and exposure to particulate matter [2,3]. Since genotoxicity possibly contributes to carcinogenesis, we investigated the mechanism of PM-induced DNA damage in lung target cells. In a previous study we demonstrated that the soluble fraction of PM was able to induce 8-hydroxydeoxyguanosine (8-OHdG) in type II epithelial cells, which was possibly related to the ability of $\mathrm{PM}$ to induce iron-dependent ${ }^{\circ} \mathrm{OH}$ formation $[9,12]$. Here we provide evidence that Fenton reaction-derived ${ }^{\circ} \mathrm{OH}$ were indeed able to hydroxylate the guanine residue when naked DNA was exposed to PM. Moreover, in addition to 8-OHdG induction in rat lung epithelial cells as previously described, PM was also shown to induce DNA strand break formation in human type II cells (A549). However, in contrast to the acellular experiments, the insoluble particle fraction was found to contribute to PM-induced DNA damage in lung target cells.

ESR using the spintrap DMPO is an established system to directly determine the formation of ${ }^{\circ} \mathrm{OH}$ [17]. Using this system we found rapid generation of ${ }^{\circ} \mathrm{OH}$ by PM. Moreover, the data indicate that this reaction was $\mathrm{H}_{2} \mathrm{O}_{2}$-dependent and could mainly be attributed to readily water-leachable constituents of PM. Interestingly, the resuspended insoluble fraction still possesses a detectable ${ }^{\circ} \mathrm{OH}$ generating capacity, suggesting that insoluble metals, and probably reactive surfaces of the (poorly soluble) particles contribute to the ability of PM to induce ${ }^{\circ} \mathrm{OH}$. This is also illustrated by observations from Ghio et al. [39], who showed that metals present in the insoluble particle fraction were still catalytically active. Inhibitory experiments using either catalase or the iron chelator deferoxamine indicated the specificity of the Fenton reaction, and more importantly, the role of soluble iron, which is the most abundant transition metal in our PM-preparations. The relevance of these effects for situations where PM fractions are in close contact with DNA, was investigated using a dotblot assay for the detection of the ${ }^{\circ} \mathrm{OH}$-specific DNA adduct 8-OHdG. Using this test system it was shown that $\mathrm{H}_{2} \mathrm{O}_{2}$ was indispensable in PM-mediated hydroxylation of DNA, clearly indicating a role of Fenton reaction-derived $\mathrm{OH}$-radicals.

To investigate the role of iron-mediated ${ }^{\circ} \mathrm{OH}$ formation in $\mathrm{PM}$-induced damage in cellular DNA, we assessed DNA strand breakage in A549 cells using the comet assay. In line with earlier observations on the induction of 8-OHdG [12], we found that PM caused strand break formation in these cells. Effects appeared to be largely mediated by iron, since strand break formation was inhibited by DFO. Non-specific effects of DFO (direct scavenging of $\left.{ }^{\circ} \mathrm{OH}\right)$ can be ruled out, because the concentration used in these experiments $(<0.4 \mathrm{mM})$ was much lower than the concentration at which DFO is reported to act as a $\mathrm{OH}$-radical scavenger $(>150 \mathrm{mM})[40]$. Therefore, these experiments suggest that both DNA strand breaks and induction of $8-\mathrm{OHdG}$ by $\mathrm{PM}$ may arise via a common chemical mechanism in which transition metals play an important role. This is confirmed by data from Toyokuni and Sagripanti [20], who showed a linear relation between strand break formation and 8-OHdG in DNA exposed to iron. However, unlike the acellular assays, we found that both DNA strand breakage as observed in the present study, and induction of 8-OHdG in type II epithelial cells [12] was possible without extracellularly added $\mathrm{H}_{2} \mathrm{O}_{2}$, suggesting the presence or generation of endogenous, intracellular $\mathrm{H}_{2} \mathrm{O}_{2}$. Considering that Fenton reaction-dependent ${ }^{\circ} \mathrm{OH}$ formation is crucial in PM-induced oxidative DNA damage, it is important to note that the ${ }^{\circ} \mathrm{OH}$ is so reactive that it can only directly hydroxylate nuclear DNA when it is generated in direct proximity [41]. For lung epithelial cells exposed to PM, this indeed implicates the presence of $\mathrm{H}_{2} \mathrm{O}_{2}$, which is confirmed by data from Dellinger et al [13] who demonstrated that DNAstrand break formation in lung cells exposed to $\mathrm{PM}$ was inhibited by the $\mathrm{H}_{2} \mathrm{O}_{2}$ scavenger catalase. They proposed a mechanism of intracellular $\mathrm{H}_{2} \mathrm{O}_{2}$ generation by $\mathrm{PM}$ itself via a 
semiquinone-induced reduction of oxygen. In addition, type II epithelial cells, used in the present study, are also known to generate $\mathrm{H}_{2} \mathrm{O}_{2}$ themselves, probably via a protein kinase Cmediated activation of a NADPH-like membrane bound enzyme [42-44]. More specifically, Ye et al [45] demonstrated that $\mathrm{H}_{2} \mathrm{O}_{2}$ was present in $\mathrm{A} 549$ cells, and that its concentration dramatically increased after exposure to the transition metal chromium. Moreover, we observed that micromolar levels of $\mathrm{H}_{2} \mathrm{O}_{2}$, as found in A549 cells significantly enhanced acellular ${ }^{\circ} \mathrm{OH}$ generation by PM. In common, these observations provide further support for our acellular data, showing the importance of $\mathrm{H}_{2} \mathrm{O}_{2}$ in PM-mediated DNA damage. In an in vivo situation $\mathrm{PM}$ has been shown to induce an influx of inflammatory phagocytes into the lung, upon release of cytokines from type II cells and/or alveolar macrophages [10,46,47]. In the present study, we showed that $\mathrm{PM}$ was able to induce $\mathrm{H}_{2} \mathrm{O}_{2}$ release by neutrophils, which would suggest that in situations of pulmonary inflammation (such as chronic obstructive pulmonary disease) the intrinsic capacity of inhaled PM to induce DNA damage may be enhanced due to an increased level of inflammatory cell-derived $\mathrm{H}_{2} \mathrm{O}_{2}$ [48].

Our data comparing PM suspensions with the particle free soluble fraction, obtained after filtration, suggest that the insoluble particle fraction contributes to DNA damage. Ideally, the effect of insoluble particles could be tested separately by the use of a PM fraction resuspended after centrifugation. As such however, effects of ultrafine particles would be ignored since they are not centrifugable [12]. In addition, electron microscopy visualisation demonstrated that particle agglomeration and distribution was dramatically changed after resuspension (data not shown), which makes it hard to compare possible effects with the original suspension. However, Don Porto Carero et al. (2001) showed that carbon black particles were able to induce DNA strand breaks in A549 cells, indicating that the insoluble carbonaceous particle fraction of PM may indeed contribute to genotoxicity [27].

In previous studies we concentrated on effects of the soluble, uncentrifugable fraction of PM, because our immunoassay, used to detect 8 -OHdG in rat type II cells, did not allow the use of dense particulates as they were found to interfere with the microscopic evaluation [12]. In the present study these problems were avoided by using the comet assay. This assay is not only a quantitative technique, but more importantly, also allows to assess particle-induced DNA damage, without the possibility of artificially induced effects due to direct contact of particles with DNA during cell processing. Using the comet assay, we and others showed that insoluble particles such as carbon black and quartz were able to induce strand breaks in A549 cells, possibly via intracellular generation of ${ }^{\circ} \mathrm{OH}[25,27]$. Recently, Stearns et al [34] showed that A549 cells were able to ingest particles, indicating that intracellular effects of insoluble particles could play a role in PM-induced DNA damage, as suggested in the present study. In preliminary experiments investigating particle uptake by A549 cells we were not able to find particles in the nucleus after 4 hours incubation (unpublished observations). This observation excludes direct nuclear effects possibly related to catalytically active surface components of the insoluble particle fraction. Moreover these data suggest that insoluble particles possibly 'act at a distance' in their contribution to PM-induced DNA damage: During uptake, particles can affect cellular membranes, leading to the induction of lipid peroxidation, a process which has been described for quartz particles [49]. Lipid peroxidation processes are known to yield products which can damage DNA, possibly via formation of ${ }^{\circ} \mathrm{OH}$. Interestingly, especially in the context of PM, this effect can be enhanced in the presence of transition metals such as iron [50]. Additionally, particles could also interfere with the intracellular level of Fenton-reactive $\mathrm{H}_{2} \mathrm{O}_{2}$, by directly activating protein kinase $\mathrm{C}$-mediated processes $[51,52]$.

In conclusion, the data presented in this paper contribute to a hypothetical mechanism of PM-induced DNA damage in type II epithelial lung cells, in which ${ }^{\circ} \mathrm{OH}$, generated by a Fenton reaction are considered to play an important role (Figure 8). Our data suggest that in this particular mechanism, apart from PM-derived transition metals, $\mathrm{H}_{2} \mathrm{O}_{2}$ is an indispensable 
factor. In addition, we demonstrated that the insoluble particle fraction contributes to the genotoxic hazard of ambient particulate matter. The implications of this mechanism for compromised people, suffering from inflammatory diseases, and reported to have increased levels of $\mathrm{H}_{2} \mathrm{O}_{2}$ in the lung, remain to be investigated.

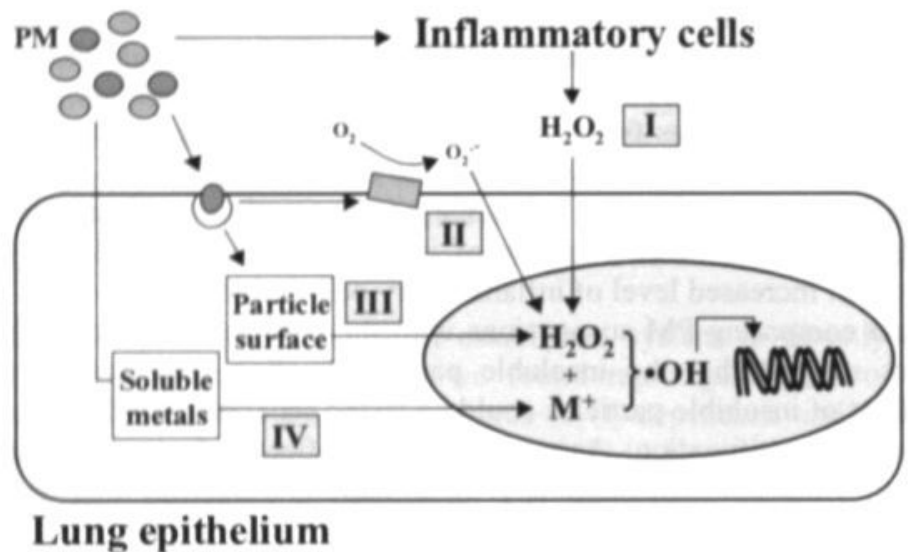

Figure 8 . Proposed mechanism of hydroxyl radical-mediated DNA damage by PM in lung epithelial cells. The scheme shows the interplay of effects suggested to be mediated by the water-soluble and the insoluble fraction of PM. To induce DNA damage, OH-radicals have to be generated within the nucleus, in close proximity to the DNA. This implicates the presence of both $\mathrm{H}_{2} \mathrm{O}_{2}$ and transition metals in the nucleus. Hydrogen peroxide in epithelial cells may be derived either from extracellular sources, such as inflammatory cells (I), or from endogenous sources. Endogenous $\mathrm{H}_{2} \mathrm{O}_{2}$ can be derived from a particle-mediated enhancement of NADPH-oxidase activity (II) [51.52]. In addition, it can be generated via intracellular oxygen reduction by particle surface radicals (III) [13]. The diffusion of iron and other soluble transition metals (M). abundantly available from PM (IV), will then provide an optimal condition for enhanced Fenton reaction-mediated $\bullet \mathrm{OH}$ generation within the nucleus.

\section{References}

1. Pope CA, Bates DV, Raizenne ME. Health effects of particulate air-pollution: Time for reassessment? Emviron Health Perspect 103: $472-480,1995$

2. Docken DW, Pope CA III, Xu X, Spengler JD, Ware JH, Fay ME, Ferris BG, Speizer FE. An association between air pollution and mortality in six U.S. cities. New Eng J Medicine 329: 1753-1759, 1993.

3. Cohen AJ. Pope CA III: Lung cancer and air pollution. Emvirnn Health Perspect 103 (suppl 8): 219-224, 1995.

4. Hornberg C. Maciuleviciute L. Seemayer NH. Sister chromatid exchanges in rodent tracheal epithelium exposed in vitro to environmental pollutants. Toxicol Lett 88: 45-53, 1996

5. Seemayer NH. Hornberg C. Hadnagy W. Comparative genotoxicity testing of airborne particulates using rodent tracheal epithelial cells and human lymphocytes in vitro. Toxicol Lett 72: 95-103, 1994.

6. Itsiao WLW. Mo ZY. Fang M. Shi XM. Wang F. Cytotoxicity of PM , and PM 2 , $_{0}$ ambient air pollutants assessed by the MTT and the Comet assays. Ifutat Res 471:45-55, 2000

7. IARC Monograph on the Evaluation of Carcinogenic Risk to Humans, vol 49: Chromium. Nickel and Welding. IARC, lyon, France, 1990.

8. Donaldson K. MacNee W. Potential mechanisms of adverse pulmonary and cardiovascular effects of particulate air pollution (PM10). Int J Hox Emvinon Health 203:411-415, 2001.

9. Gilmour PS, Brown DM, I indsday TG, Beswich PH, MacNee W, Donaldson K. Adverse health effects of PMI0 particles: involvement of iron in generation of hydroxyl radical. Orcup Emviron Med 53: 817-822, 1996.

10. Li XY. (iilmour PS, Donaldson K. Mac Nee W. In vivo and in vitro proinflammaton effects of particulate air pollution $\left(\mathrm{PM}_{\text {to }}\right)$. Emvinu Hewh Perswy 105 (suppl 5): 1279-1283, 1997

11. Prahalad AK. Soukup JM. Inmon J, Willis R. Ghio AJ. Becker S. Gallagher JE. Ambient air particles: effects on cellular oxidant radical generation in relation to particulate elemental chemistry. Toxicol Appl Pharmacol 158: 81-91. 1000.

12. Knaapen AM. Schins RPF. Steinfartz Y. Hohr D. Dunemann L. Borm PJA. Ambient particulate manter induces oxidative DNA damage in lung epithelial cells. Inhal Toxicol 12 (suppl 3): 125-132. 2000. 
13. Dellinger B. Pryor WA, Cueto R, Squadrito GL. Hegde V. Deutsch WA. Role of free radicals in the toxicity of airborne fine particulate matter. Chem Res Toxicol 14: 1371-1377, 2001

14. Prahalad, AK, Inmon J, Dailey LA, Madden MC, Ghio AJ. Gallagher JE. Air pollution particles mediated oxidative DNA base damage in a cell free system and in human airway epithelial cells in relation to particulate metal content and bioreactivity. Chem Res Toxicol 14: 879-887, 2001.

15. Pryor, W.A. Why is the hydroxyl radical the only radical that commonly adds to DNA? Free Radic Biol Med $4: 219$. 223. 1988.

16. Halliwell B, Gutteridge JM. Free radicals in biology and medicine, $2^{\text {nd }}$ ed. Clarendon Press, Oxford, 1989.

17. Lloyd RV, Hanna PM, Mason RP. The origin of the hydroxyl radical oxygen in the fenton reaction. Free Radic Biol Med 22: 885-888, 1997.

18. Harrison RM, Y in J. Particulate matter in the atmosphere: which particle properties are important for its effects on health. Sci Total Emviron 249: 85, 101.

19. Lloyd DR, Carmichael PL. Phillips DH. Comparison of the formation of 8-hydroxy-2'-deoxyguanosine and single- and double-strand breaks in DNA mediated by fenton reactions. Chem Res Toxicol $11: 420-427,1998$.

20. Toyokuni S, Sagripanti JL. Association between 8-hydroxy-2'-deoxyguanosine formation and DNA strand breaks mediated by copper and iron. Free Radic Biol Med 20: 859-864, 1996.

21. Prahalad AK. Inmon J, Ghio AJ, Gallagher JE. Enhancement of 2'-deoxyguanosine hydroxylation and DNA damage by coal and oil fly ash in relation to particulate metal content and availability. Chem Res Toxicol 13: 1011-1019, 2000.

22. Van Maanen JMS, Borm PJA, Knaapen AM, van Herwijnen M, Schilderman PAEL, Smith KR, Aust AE, Tomatis M. Fubini B. In vitro effects of coal fly ashes: Hydroxyl radical generation, iron release, and DNA damage and toxicity in rat lung epithelial cells. Inhal Toxicol 11: 1123-1141, 1999.

23. Seaton A, MacNee W. Donaldson K, Godden D. Particulate air pollution and acute health effects. The Lancet 345 ; 176 . 178,1995

24. Donaldson K, Li XY, MacNee W. Ultrafine (nanometre) particle mediated lung injury. J Aerosol $S c i$ 29:553-560, 1997.

25. Schins RPF. Mechanisms of genotoxicity of particles and fibres. Inhal Toxicol 14: 57-78, 2002

26. Daniel LN, Mao Y, Saffiotti U. Oxidative DNA damage by crystalline silica. Free Radic Biol Med 14:463-472, 1993.

27. Don Porto Carero A. Hoet PHM, Verschaeve L. Schoeters G. Nemery B. Genotoxic effects of carbon black particles. diesel exhaust particles, and urban air particulates and their extracts on a human alveolar epithelial cell line (A549) and a human monocytic cell line (THP-1). Emviron Mol Mutagen 37: 155-163, 2001.

28. Peters A. Skorkovsky J, Kotesovec F, Brynda J. Spix C, Wichmann HE, Heinrich J: Associations between mortality and air pollution in central Europe. Environ Health Perspect 108: 283-287, 2000

29. Shi T, Knaapen AM, Begerow J, Birmili W, Borm PJA, Schins RPF. Hydroxyl radical generation and formation of 8 hydroxy-2'-deoxyguanosine by coarse and fine particulate matter. Occup Emviron Health, submitted.

30. Musarrat J, Wani AA Quantitative immunoanalysis of promutagenic 8-hydroxy-2'-deoxyguanosine in oxidized DNA. Carcinogenesis 15: 2037-2043, 1994.

31. Toyokuni S. Tanaka T. Hattori Y. Nishiyama Y, Yoshida A. Uchida K, Hiai H, Ochi H, Osawa T. Quantitative immunohistochemical determination of 8-hydroxy-2'-deoxyguanosine by a monoclonal antibody N45.1: Its application to ferric nitrolotriacetate-induced renal carcinogenesis model. Lab Invest 76:365-374, 1997.

32. Pick E. Keisari Y A simple colorimetric method for the measurement of hydrogen peroxide produced by cells in culture. J Immunol Meth 38: 161-170, 1980.

33. Knaapen AM, Seiler F. Schilderman PAEL. Nehls P. Bruch J, Schins RPF, Borm PJA. Neutrophils cause oxidative DNA damage in alveolar epithelial cells. Free Radic Biol Med 27: 234-240, 1999.

34. Stearns RC, Paulauskis JD, Godleski JJ. Endocytosis of ultrafine particles by A549 cells. Am J Respir Cell Mol Biol 24 108-115, 2001

35. Ollikainen T. Puhakka A. Kahlos K. Linnainmaa K. Kinnula VI. Modulation of cell and DNA damage by poly(ADP)ribose polymerase in lung cells exposed to $\mathrm{H} 2 \mathrm{O} 2$ or asbestos fibres. Mutat Res 470: 77-84, 2000.

36. Singh NP, McCoy MT. Tice RR, Schneider EL. A simple technique for quantitation of low levels of DNA damage in individual cells. Exp Cell Res 175: 184-191. 1988.

37. Tice RR. Agurell E, Anderson D, Burlinson B. Hartmann A, Kobayashi H, Miyamae Y, Rojas E, Ryu JC, Sasaki YF. Single cell gel comet assay: guidelines for in vitro and in vivo genetic toxicology testing. Fmviron Mol Mutagen 35 . 206-221. 2000.

38. Collins AR, Ma AG, Duthic SJ. The kinetics of repair of oxidative DNA damage (strand breaks and oxidised pyrimidines) in human cells. Mutat Res 336: 69-77, 1995

39. Ghio AJ. Stonehuerner J. Daily LA. Carter JD. Metals associated with both the water-soluble and insoluble fractions of an ambient air pollution particle catalyze an oxidative stress. Inhal Toxicol I I: 37-49, 1999

40. Morel I. Cillard J. Lescoat G, Sergent O, Pasdeloup N, Ocaktan AZ. Abdallah MA. Brissot P. Cillard P. Antioxidant and free radical scavenging activities of the iron chelators pyoverdin and hydroxypyrid-4-ones in iron-loaded hepatocyte cultures: comparison of their mechanism of protection with that of desferrioxamine. Free Rad Biol Med 13: 499-508, 1992.

41. Henle ES, I.inn S. Formation, prevention, and repair of DNA damage by iron/hydrogen peroxide. J Biol Chem 272: 19095-19098, 1997

42. Piotrowski WJ. Marczak J. Dinsdale D. Kurmanowska Z, Tarasow Y. Komos J. Nowak D. Release of hydrogen peroxide by rat type II pneumocytes in prolonged culture. Toxicol In Vitro 14:85-93, 2000

43. Van Klaveren RJ. Roelant C. Boogaerts M. Demedts M. Nemery B. Involvement of an NAD(P)H oxidase-like enzyme in superoxide anion and hydrogen peroxide generation by rat type II cells. Thorax 52:465-471, 1997 . 
44. Kinnula VL, Everitt J, Whorton AR, Crapo JD. Hydrogen peroxide production by alveolar type II cells, alveolar macrophages, and endothelial cells. Am J Physiol 261: L84-91, 1991.

45. Ye J, Wang S, Leonard SS, Sun Y, Butterworth L, Antonini J, Ding M, Rojanasakul Y, Vallyathan V, Castranova V. Shi X. Role of reactive oxygen species and P53 in chromium(VI)-induced apoptosis. $J$ Biol Chem 274: 34974-34980, 1999.

46. Jimenez L.A, Thompson J, Brown DA, Rahman I, Antonicelli F, Duffin R, Drost EM, Hay RT, Donaldson K, MacNee W. Activation of NF-kappaB by $\mathrm{PM}(10)$ occurs via an iron-mediated mechanism in the absence of IkappaB degradation. Toxicol Appl Pharmacol 166: 101-110, 2000.

47. Shukla A, Timblin C, Berube K, Gordon T, McKinney W, Driscoll K, Vacek P, Mossman BT. Inhaled particulate matter causes expression of nuclear factor (NF)-kappaB-related genes and oxidant-dependent NF-kappaB activation in vitro. Am J Respir Cell Mol Biol 23: 182-187, 2000.

48. Repine JE, Bast A, Lankhorst I, and The oxidative stress study group. Oxidative stress in chronic obstructive pulmonary disease. Am J Repir Crit Care Med 156: 341-357, 1997.

49. Shi X, Mao Y, Daniel LN, Saffiotti U, Dalal NS, Vallyathan V. Silica radical-induced DNA damage and lipid peroxidation. Environ Health Perspect 102 (suppl 10): 149-154, 1994.

50. Park JW, Floyd RA. Lipid peroxidation products mediate the formation of 8-hydroxydeoxyguanosine in DNA. Free Radic Biol Med 12: 245-250, 1992.

51. Perderiset M, Marsh JP, Mossman BT. Activation of protein kinase C by crocidolite asbestos in hamster tracheal epithelial cells. Carcinogenesis 12: 1499-1502, 1991.

52. Gercken G, Berg I, Dorger M, Schluter T. Mechanisms of particle-induced activation of alveolar macrophages. Toxicol Lett 88: $121-129,1996$. 


\title{
Chapter 4
}

\section{Oxidant-induced DNA damage by quartz in alveolar epithelial cells}

\author{
Roel PF Schins, Ad M Knaapen, Gonca D Cakmak, Tingming Shi, \\ Christel Weishaupt, and Paul JA Borm
}

Department of Fibre \& Particle Toxicology. Medical Institute of Environmental Hygiene.

Auf 'm Hennekamp 50, 40225 Düsseldorf, Germany

\begin{abstract}
Respirable quartz has recently been classified as a human carcinogen. Although studies with quartz using naked DNA as a target suggest that formation of oxyradicals by particles may play a role in the DNA-damaging properties of quartz, it is not known whether this pathway is important for DNA damage in the target cells for quartz carcinogenesis, i.e. alveolar epithelial cells. Therefore, we determined in vitro DNA damage by DQ12 quartz particles in rat and human and alveolar epithelial cells (RLE, A549) using the single cell gel electrophoresis/comet assay. The radical generation capacity of quartz was analysed by electron spin resonance (ESR), and by immunocytochemical analysis of the hydroxyl radicalspecific DNA lesion 8-hydroxydeoxyguanosine (8-OHdG) in the epithelial cells.

Quartz particles as well as the positive control hydrogen peroxide, caused a dosedependent increase in DNA strand breaks in both cell lines. DNA damage by quartz was significantly reduced in the presence of the hydroxyl-radical scavengers mannitol and DMSO. The involvement of hydroxyl radicals was further established by ESR measurements, and was also demonstrated by the ability of the quartz to induce formation of $8-\mathrm{OHdG}$. In conclusion, our data show that quartz elicits DNA damage in rat and human alveolar epithelial cells, and indicate that these effect are driven by hydroxyl radical-generating properties of the particles.
\end{abstract}

Based on: Mutation Research 517: 77-86, 2002. 


\section{Introduction}

Respirable quartz has been classified as a carcinogen by the International Agency for Research on Cancer [1]. Studies on the physicochemical properties of quartz particles indicate that oxyradicals, such as $\mathrm{O}_{2}{ }^{\circ},{ }^{\circ} \mathrm{OH}$ and ${ }^{1} \mathrm{O}_{2}$ are involved in the cytotoxic, inflammogenic, and fibrogenic effects of quartz [2-10]. Also with regard to the carcinogenicity of quartz, a role for oxyradicals has been proposed [4,11]. Studies by Daniel et al. [12], point towards a major role for the hydroxyl radical $(\mathrm{OH})$, since damage to naked DNA by quartz was enhanced in the presence of superoxide dismutase and $\mathrm{H}_{2} \mathrm{O}_{2}$, whereas damage could be blocked by catalase or DMSO. It has been proposed that this radical, despite its extremely short half-life may exert its effects as a result from direct binding of quartz particles to DNA [11,13].

Support for the involvement of oxyradicals in the genotoxicity of quartz also comes from a number of animal studies. Enhanced formation of the ${ }^{\circ} \mathrm{OH}$-specific and premutagenic DNA lesion 8-hydroxydeoxyguanosine (8-OHdG) [14] has been observed in rat lungs upon intratracheal instillation with quartz [15-17]. Immunohistochemical analysis of 8-OHdG indicates that DNA damage merely occurs in cells of the alveolar region [17], and the epithelial cells in this region are considered as target cells for quartz-induced lung carcinogenesis [18,19]. Notably, these in vivo genotoxic effects are considered to be a consequence of the ability of the dusts to induce lung inflammation with excessive formation of ROS by activated neutrophils and macrophages [17,19-21]. This concept is further supported by in vitro co-incubation experiments, showing that inflammatory cells as well as hydrogen peroxide induce 8-OHdG formation and hprt-mutations in rat alveolar epithelial cells $[19,22,23]$. However, several research groups have also demonstrated genotoxic properties of quartz in the absence of inflammatory cells, i.e. using a variety of in vitro systems including the single cell electrophoresis/comet assay [24-31]. Importantly however, in these studies no cells of epithelial origin were used, whereas alveolar epithelial cells are the major target cells for neoplastic effects induced by poorly soluble dusts such as quartz $[18,19]$. Furthermore, a clear role for ${ }^{\circ} \mathrm{OH}$, as proposed from observations with naked DNA and indicated from in vivo studies, has so far not been established from in vitro genotoxicity studies with quartz.

The aim of our present study was to determine whether respirable quartz particles elicit DNA damage in alveolar epithelial cells, and whether hydroxyl radicals play a role in here. Therefore, DNA damage by quartz was evaluated in lung epithelial cell lines of rat (RLE) and human (A549) origin, using the comet-assay. The hydroxyl radical-generating capacity of the quartz was analysed by electron spin resonance (ESR), and by immunocytochemical analysis of 8-OHdG. Hydrogen peroxide, known for its ${ }^{\circ} \mathrm{OH}$-mediated induction of 8-OHdG and DNA strand breakage was used as a positive control [32-36]. In the present study, we demonstrate that respirable quartz particles induce DNA damage in alveolar epithelial cells, and provide evidence that, as with the genotoxicity of hydrogen peroxide, $\mathrm{OH}$ may play a major role in the observed genotoxic effects elicited by quartz.

\section{Materials and Methods}

\section{Chemicals}

Dulbecco's Modified Eagle's Medium (DMEM), HAM F12, Foetal calf serum (FCS), Lglutamine, penicillin-streptomycin, Trypsin-EDTA, HEPES buffer, Sodium Pyruvate, $\beta$ NADH, 2,4-dinitrophenylhydrazine, Ethidium bromide, DMSO, Agarose, low melting point agarose (LMPA), Tris-base, Triton $\mathrm{X}-100, \mathrm{Na}$-Lauroyl sarcosinate, Na-formate, 5,5-dimethyl1-pyrroline-N-oxide (DMPO), and $\mathrm{H}_{2} \mathrm{O}_{2}$ were obtained from Sigma-Aldrich (Taufkirchen, 
Germany). Hanks Balanced Salt Solution (HBSS) was obtained from Life-Technologies (Kahrlsruhe, Germany). DQ12 (batch 6, MIU) was used as a standard quartz.

\section{Cell culture and treatment of cells}

RLE cells were kindly provided by Dr. K. Driscoll (Procter \& Gamble, Cincinnati, USA), and were grown in HAM F12 supplemented with $5 \%$ heat inactivated FCS, L-glutamine, $1 \% 1 \mathrm{M}$ HEPES buffer, and $30 \mathrm{IU} / \mathrm{ml}$ penicillin-streptomycin. A549 cells (American Type Culture Collection), were grown in DMEM culture medium supplemented with $10 \%$ heat inactivated FCS, L-glutamine, and $30 \mathrm{IU} / \mathrm{ml}$ penicillin-streptomycin. For experiments, cells were trypsinised at confluency, seeded into 24 well tissue culture plates and grown until confluency. The cells were rinsed two times with phosphate buffered saline (PBS), and then treated for 4 hours. Therefore, quartz was suspended in HBSS, sonicated for 5 minutes in a water bath, and diluted into the culture dishes at the indicated final concentrations. As a positive control, cells were treated for 2 hours with $\mathrm{H}_{2} \mathrm{O}_{2}$ dissolved in HBSS. In some experiments $40 \mathrm{mM}$ mannitol or $0.5 \%$ DMSO, used as ${ }^{\circ} \mathrm{OH}$ scavengers, were added to the cells 30 minutes before addition of the particles.

\section{Single cell gel electrophoresis}

Single cell gel electrophoresis $[26,27]$ was performed according to currently recommended guidelines [28]. At the end of each incubation, the epithelial cells were rinsed twice with PBS, detached by trypsination $(50 \mu \mathrm{l}, 2 \mathrm{~min})$, and immediately suspended in FCS-containing DMEM or Ham-F12. Cells were centrifugated for 5 minutes at $400 \mathrm{~g}$, and resuspended in HBSS. Cell yield and viability of each incubation were then assessed by a Neubauer hematocytometer using trypan blue dye exclusion. A mixture of $25 \mu \mathrm{l}$ cell suspension and 75 $\mu \mathrm{l} 0.65 \%$ low melting point agarose (LMPA), was added to $0.65 \%$ agarose-covered fully frosted slides. Following solidification, the slides were covered by another layer of LMPA $(100 \mu \mathrm{l})$. Slides were lysed overnight at $4^{\circ} \mathrm{C}$ in lysis buffer $(2.5 \mathrm{M} \mathrm{NaCl}, 100 \mathrm{mM}$ EDTA, 10

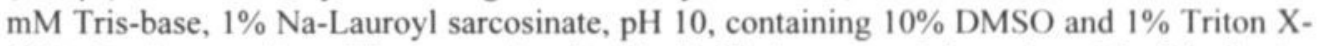
$100)$. On the next day, slides were rinsed with distilled water and then placed for 30 minutes in an electrophoresis tank filled with ice-cold electrophoresis buffer $(300 \mathrm{mM} \mathrm{NaOH}, 1 \mathrm{mM}$ EDTA, $\mathrm{pH}=13$ ). The electrophoresis tank was kept in an ice bath, and electrophoresis was conducted at $300 \mathrm{~mA}$ and $25 \mathrm{~V}$ for 15 minutes. Slides were neutralised $3 \times 5$ min using neutralisation buffer $(0.4 \mathrm{M}$ Tris, $\mathrm{pH}=7.5)$. All steps described were performed in the dark or under dimmed red light to prevent additional DNA damage. Slides were stained with ethidium bromide $\left(20 \mu \mathrm{g} / \mathrm{ml}\right.$ in $\left.\mathrm{H}_{2} \mathrm{O}\right)$ and comet appearances were analysed on an Olympus BX60 fluorescence microscope at $200 \mathrm{x}$ magnification. For each experiment, two slides were used per treatment, and for each slide at least 50 cells were analysed randomly, using a comet image analysis software program (Comet Assay II, Perceptive Instruments, Haverhill, UK). Comet parameters evaluated included tail length, \% tail DNA and the tail moment.

\section{Determination of $\mathrm{LDH}$}

Cytotoxicity was determined by measurement of the release of lactate dehydrogenase (LDH) as an indicator of cell membrane damage, and was based on the method as described by Brown et al. [37]. Briefly, the LDH activity of the test samples or standards was measured using pyruvic acid as substrate on an automatic plate reader (Multiskan, Labsystems, Heslinki, Finland) at $540 \mathrm{~nm}$.

\section{Electron spin resonance}

The ability of the quartz particles to generate hydroxyl radicals, both in the presence and absence of $\mathrm{H}_{2} \mathrm{O}_{2}$ was evaluated by electron spin resonance (ESR). Briefly, $50 \mu \mathrm{l}$ of distilled 
deionised water, $50 \mu \mathrm{l}$ of $0.5 \mathrm{M} \mathrm{H}_{2} \mathrm{O}_{2}$ in PBS and $100 \mu \mathrm{l}$ of the spin trap $0.05 \mathrm{M}$ of $5,5-$ dimethyl-1-pyrroline-N-oxide (DMPO) in distilled deionised water were added to $4 \mathrm{mg}$ of DQ12. This suspension was incubated in a shaking water bath for $15 \mathrm{~min}$ at $37^{\circ} \mathrm{C}$, and filtered through a Sartorius $0.22 \mu \mathrm{m}$ pore filter. The filtrate was then transferred to a capillary and DMPO-OH adduct formation was measured with a Miniscope ESR spectrometer (Magnettech, Berlin, Germany). For $\mathrm{H}_{2} \mathrm{O}_{2}$-independent radical formation, $20 \mathrm{mg}$ of DQ12 was incubated for 1 hour with $50 \mu \mathrm{l}$ of distilled deionised water, $50 \mu \mathrm{l}$ of PBS and $100 \mu \mathrm{l}$ of $0.05 \mathrm{M}$ of DMPO in distilled deionised water. The ESR-spectra were recorded at room temperature using the following instrumental conditions: Magnetic field: $3360 \mathrm{G}$, sweep width: $100 \mathrm{G}$, scan time: $30 \mathrm{sec}$, number of scans: 3 , modulation amplitude: $1800 \mathrm{G}$.

\section{Determination of 8-hydroxydeoxyguanosine}

Formation of 8 -hydroxydeoxyguanosine $(8-\mathrm{OHdG})$ was determined by immunocytochemistry as described previously [23], with some minor modifications. Briefly, cells were seeded in 4Chamber Slides (Falcon) at a concentration of 120,000 cells/chamber. After 48 hours, cells were exposed to 20 or $80 \mu \mathrm{g} / \mathrm{cm}^{2}$ quartz for 4 hours. Immunocytochemistry was performed using the monoclonal 8-OHdG antibody [38], and the Vectastain-ABC kit (Vector Laboratories, Burlingame, CA). $8-\mathrm{OHdG}$ was quantified using a digital imaging software analysis system (SIS, Münster, Germany). Therefore, at least three chambers were analysed per treatment, counting at least 100 cells per chamber.

\section{Statistical analysis}

Data are expressed as mean \pm standard deviations unless stated otherwise. Statistical analysis was performed using SPSS v.10 for Windows. Treatment-related differences were evaluated using Student's t-test. A difference was considered significant at $\mathrm{p}<0.05$.

\section{Results}

To evaluate the feasibility of RLE cells and A549 cells for DNA strand breakage analysis by the comet assay, hydrogen peroxide was used as a positive control. The results of these experiments are shown in figure 1. DNA damage was observed in both cell types, but the effects of hydrogen peroxide were much stronger in the RLE cells than in the A549 cells. Whereas in RLE cells significant damage was observed at a concentration of $50 \mu \mathrm{M}$, in A549 cells hydrogen peroxide was only effective at a concentration of $200 \mu \mathrm{M}$.

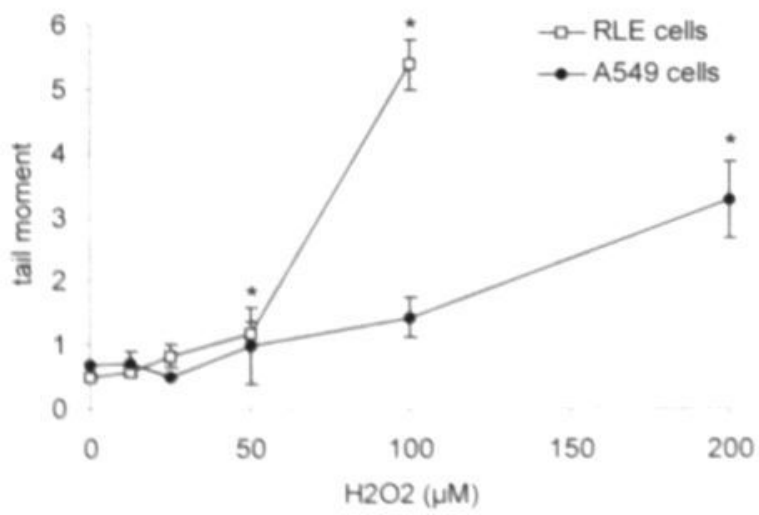

Figure 1. DNA strand breakage in RIF cells and A.549 cells upon treatment with hydrogen peroxide for 2 hours. Data represent mean \pm standard deviation: " p 0.05 versus controls $\left(=0 \mu \mathrm{M} \mathrm{H}, \mathrm{O}_{2}\right)$ 
Induction of DNA strand breakage in RLE cells or A549 cells upon treatment with DQ12 quartz, in relation to viability of the processed cells is shown in Figure 2. As can be seen in both graphs, quartz particles were found to elicit a concentration-related increase in DNA strand breakage in both cell types. DNA damage was significantly increased for both cell types at a concentration of and above $40 \mu \mathrm{g} / \mathrm{cm}^{2}$. At lower concentrations, DNA damage was not significantly increased. The relative increase in tail moment per log unit mass appeared to be approximately 4 -fold higher for RLE cells $\left(y=1.48 x+1.95 ; r^{2}=0.64, p<0.01\right)$ compared to the A549 cells $\left(y=0.39 x+1.10 ; r^{2}=0.36, p<0.01\right)$. Trypan blue dye exclusion indicated a significant loss in viability of RLE cells at a quartz doses of $40 \mu \mathrm{g} / \mathrm{cm}^{2}$ and 200 $\mu \mathrm{g} / \mathrm{cm}^{2}$ whereas in the A549 cells, viability was only reduced at the highest dose of 200 $\mu \mathrm{g} / \mathrm{cm}^{2}$ (see Fig. 2).

\section{A. RLE cells}

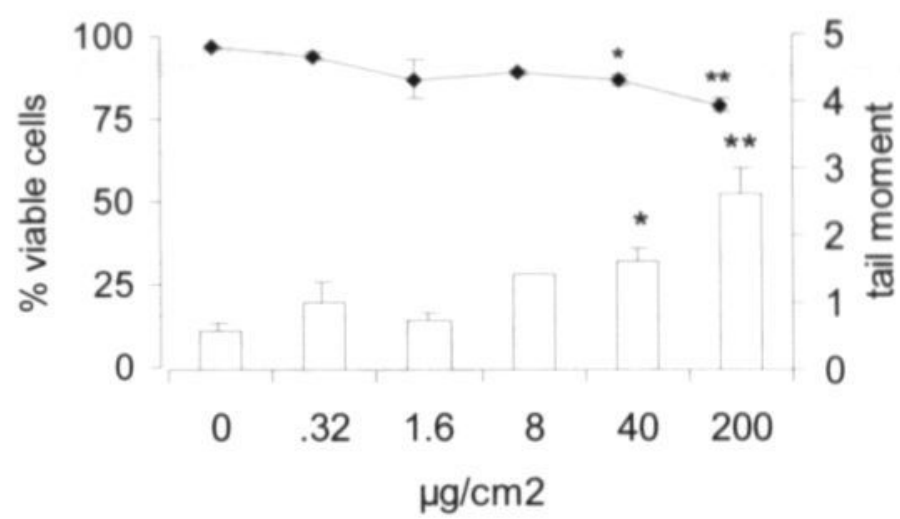

\section{B. A549 cells}

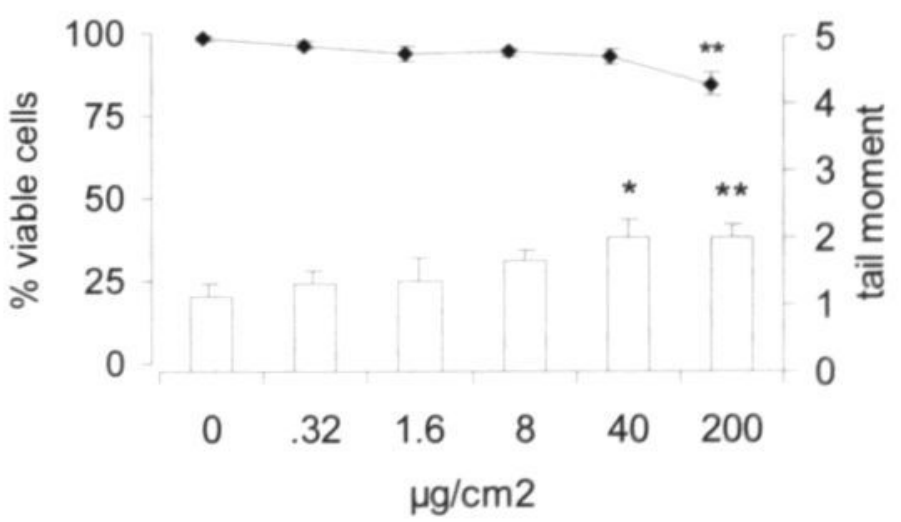

Figure 2. Viability (lines) and DNA strand breakage (bars) in RLE cells (A) and in A549 cells (B) upon 4 hours treatment with DQ12 quartz. Data represent mean + SEM; * $p<0.05$ and $* p<0.01$ versus controls $\left(=0 \mu \mathrm{g} / \mathrm{cm}^{2}\right)$. 
As an additional measurement of cytotoxicity of the quartz particles, the release of LDH from the RLE cells or A549 cells was used. The results are shown in figure 3 . In agreement with the results of the trypan blue test, significant toxicity was observed in RLE cells with DQ12 concentrations of 40 and $200 \mu \mathrm{g} / \mathrm{cm}^{2}$, whereas in A549 cells toxicity was only observed at a concentration of $200 \mu \mathrm{g} / \mathrm{cm}^{2}$.

Electron spin resonance was used to determine whether DQ12 quartz elicits formation of ${ }^{\circ} \mathrm{OH}$, both in the presence and in the absence of $\mathrm{H}_{2} \mathrm{O}_{2}$. The ESR spectra for these experiments are shown in figure 4 . In the presence of $\mathrm{H}_{2} \mathrm{O}_{2}$ the spectrum showed the ${ }^{\circ} \mathrm{OH}$ specific 1:2:2:1 quartet pattern with quartz (panel A). The absence of a detectable DMPO-OH signal with hydrogen peroxide alone (panel B), shows that no 'Fenton-active' metal impurities were present in the water used for the ESR measurements, and which might have lead to a false-positive signal for quartz. The spectrum as observed with quartz in the absence of $\mathrm{H}_{2} \mathrm{O}_{2}$ (panel $\mathrm{C}$ ) is also indicative of "OH formation. However, this was only observed when five-fold higher quartz concentrations and longer incubation times were used, and the resulting spectrum also indicates trapping of other radical species besides ${ }^{\circ} \mathrm{OH}$, such as $\mathrm{O}_{2}{ }^{\circ}$ 17.81.
A. RLE cells
B. A549 cells
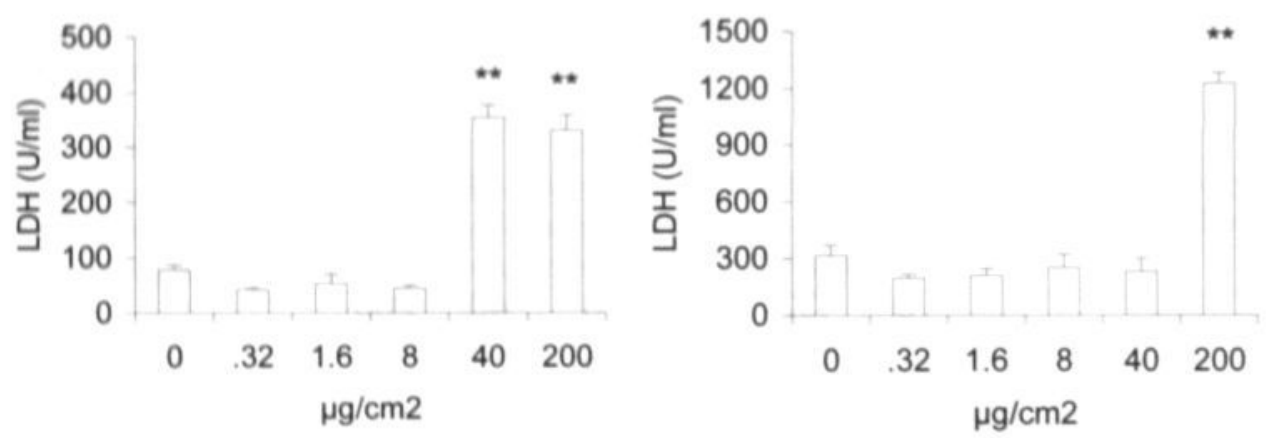

Figure 3. Cytotoxicity (LDH-release) in RL.E cells (A) and A549 cells (B) upon treatment with DQ12 quartz particles for 4 hours, Data represent mean $+\mathrm{SEM} ;{ }^{\cdots} \mathrm{p}<0.01$ versus controls $\left(=0 \mu \mathrm{g} / \mathrm{cm}^{2}\right)$.

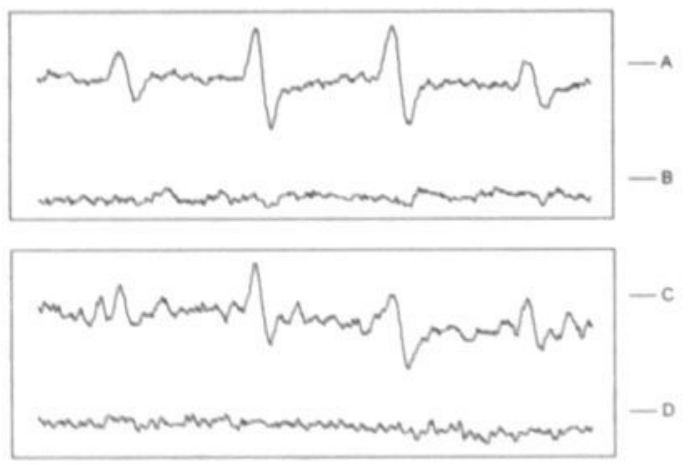

Figure 4. ESR measurements of DQ12 quartz. Graphs A and B represent the signals as observed upon 15 min. incubation of DMPO in the presence of hydrogen peroxide. A - quartz $(20 \mathrm{mg} \mathrm{ml})$ plus hydrogen peroxide; $\mathrm{B}=$ hydrogen peroxide alone. Graphs $\mathrm{C}$ and $\mathrm{D}$ show the spectra as observed upon Ihr incubation of DMPO in the absence of hydrogen peroxide. $\mathrm{C}=$ with quartz (100mg $\mathrm{ml})$; $\mathrm{D}$ - without quartz. 
To determine the role of ${ }^{\circ} \mathrm{OH}$ in the formation of DNA strand breaks by quartz, RLE cells were treated with DQ12 upon pre-incubation with the ${ }^{\circ} \mathrm{OH}$-scavengers mannitol or DMSO. These data are shown in Table 1. Both mannitol and DMSO caused a reduction of DNA strand breaks induced by DQ12. However, whereas comet tail length was significantly reduced with both scavengers, for the comet parameters \% tail DNA and tail moment significance was only reached with mannitol. Trypan blue analysis indicated a slight decrease in viability of the cells that had been treated with both DMSO and quartz. Mannitol and DMSO alone had no effect on DNA strand break formation or cell viability. Using A549 cells, we also found significant inhibition of quartz-induced strand breakage by the hydroxylradical scavenger tetramethlythiourea (TMTU) (data not shown).

Table 1. Effect of mannitol or DMSO on DNA strand breakage by quartz in RLE cells.

$\begin{array}{ll}\text { Comet parameters } & \text { Viability }(\%)\end{array}$

Tail length $\quad$ \% Tail DNA Tail moment

\begin{tabular}{|c|c|c|c|c|}
\hline Quartz & $24.2 \pm 2.8$ & $10.7 \pm 3.0$ & $1.4 \pm 0.5$ & $93.1 \pm 1.9$ \\
\hline Quartz + Mannitol & $19.8 \pm 1.7^{\circ}$ & $5.7 \pm 2.5^{\bullet}$ & $0.7 \pm 0.4^{*}$ & $93.7 \pm 2.1$ \\
\hline Quartz + DMSO & $20.2 \pm 2.4^{*}$ & $8.1 \pm 1.9$ & $1.0 \pm 0.2$ & $88.9 \pm 1.3^{*}$ \\
\hline Control & $19.0 \pm 0.9$ & $5.1 \pm 2.0$ & $0.7 \pm 0.4$ & $99.2 \pm 1.1$ \\
\hline Mannitol & $19.1 \pm 1.3$ & $4.9 \pm 3.0$ & $0.7 \pm 0.5$ & $95.5 \pm 3.6$ \\
\hline DMSO & $19.5 \pm 2.1$ & $3.5 \pm 2.1$ & $0.5 \pm 0.4$ & $97.3 \pm 1.4$ \\
\hline
\end{tabular}

- p $<0.05$ versus quartz; Independent experiments were used to test the effects of mannitol and DMSO alone

To confirm the role of ${ }^{\circ} \mathrm{OH}$ in the induction of DNA damage by quartz, immunocytochemical analysis of $8-\mathrm{OHdG}$ was performed following treatment of the RLE cells with quartz. Results are shown in the Figures 5 . As can be seen in the figures, DQ12 quartz caused increased formation of this hydroxyl radical-specific DNA-lesion. Software analysis indicated a 3.5 fold increase in staining intensity for $8-\mathrm{OHdG}$ upon treatment with 80 $\mu \mathrm{g} / \mathrm{cm}^{2}$ quartz. No increase in staining intensity was observed in RLE cells with a quartz dose of $20 \mu \mathrm{g} / \mathrm{cm}^{2}$ (not shown).

\section{Discussion}

Although the exact mechanisms by which inhalation of quartz may lead to cancer are not yet fully understood $[9,10]$, a role for reactive oxygen species, and more specifically "OH has been proposed $[4,8,11,12]$. In the present study we demonstrate that quartz elicits DNA strand breakage and formation of $8-\mathrm{OHdG}$ in human and rat alveolar epithelial cells in vitro. DNA damage was also observed with hydrogen peroxide, which was used as a positive control $[32,33,36]$. We also showed that DQ12 quartz causes ${ }^{\circ} \mathrm{OH}$ generation, and that co-treatment with the $\mathrm{OH}$ scavengers mannitol or DMSO reduces quartz-induced strand breakage. In agreement with our current observations, DNA strand break formation by quartz was recently 
also shown in a number of non-epithelial cell types using the comet assay [29-31]. In our hands, dose-response studies showed that DNA damage by DQ12 quartz in A549 cells already occurred at a dose (i.e. $40 \mu \mathrm{g} / \mathrm{cm}^{2}$ ) where cytotoxicity (trypan blue, LDH) did not occur. Thus, in these cells the genotoxic response appeared not to arise from DNA damage associated with cytotoxicity $[28,39]$, whereas in RLE cells DNA damage as seen with quartz could at least to some extent result from or lead to cytotoxicity. Interestingly, the different slopes of the dose-effect relations indicate marked stronger effects for quartz as well as for hydrogen peroxide in the RLE cells compared to the A549 cells with regard to DNA strand breakage per unit dose. The higher resistance of the A549 cells possibly relates to the high antioxidant status in these cells (unpublished observations), but might also reflect other differences between both cell lines, such as cell growth rate and transformation state, or efficiencies of DNA-repair mechanisms.

A major aspect of our present study has been the evaluation of DNA damage in lung epithelial cells. This is important in view of the specific behaviour of particulate materials in comparison to soluble chemicals [40], and the specificity of these cells as target for quartzassociated lung carcinogenesis $[18,19]$. Both cell lines used in our present study have structural and biochemical characteristics of type II cells [41-43]. More importantly however, with regard to genotoxicity testing, lung epithelial cells have been demonstrated to ingest quartz particles following inhalation $[44,45]$, and intimate contact between particles and DNA has been considered as a prerequisite of oxyradical-mediated strand breakage [13]. Ongoing studies in our laboratory indicate that A549 cells as well as the RLE cells are able to ingest quartz particles in a dose and time dependent manner [40] (Höhr et al., manuscript in preparation).
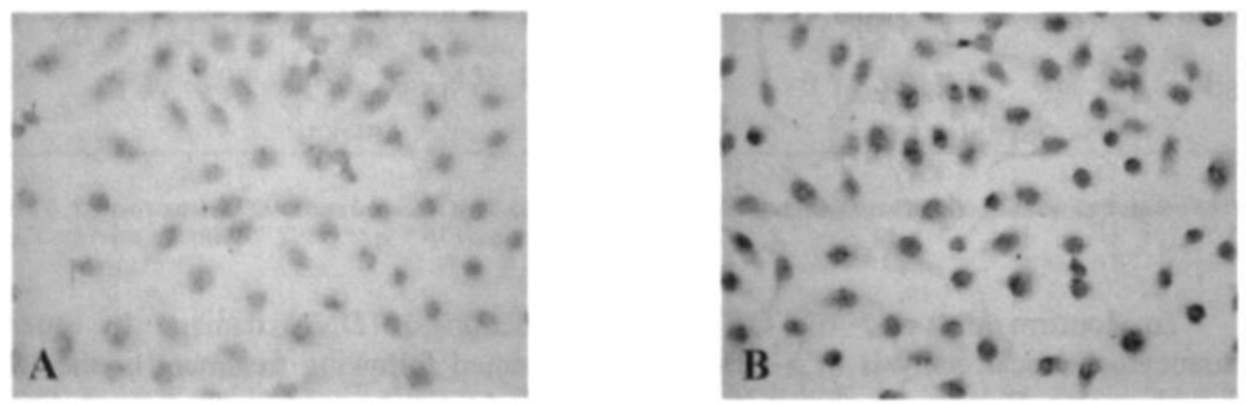

Figure 5. Immunocytochemical staining of $8-\mathrm{OHdG}$ staining in RLE cells, following 4 hours treatment with $80 \mu \mathrm{g} / \mathrm{cm}^{2} \mathrm{DQ} / 2$ quart/ particles. A - control; B quartz treated. Pictures were taken at $400 \mathrm{x}$ magnification. Software analysis (see methods section for details) indicated a 3.5 fold increase in staining intensity for 8-OHdG by quartz

The ESR measurements performed in the present study, are in line with previous observations by others [2-8], and also confirm that our batch of DQ12 dust indeed generates ${ }^{\circ} \mathrm{OH}$. Importantly, when considered on equal mass, the $\mathrm{H}_{2} \mathrm{O}_{2}$-independent generation of ${ }^{\circ} \mathrm{OH}$ by quartz was negligible compared to the effects as seen in the presence of $\mathrm{H}_{2} \mathrm{O}_{2}$. These data suggest that $\mathrm{H}_{2} \mathrm{O}_{2}$, endogenously produced by alveolar epithelial cells [46-47], and/or derived from phagocytic cells during lung inflammation [21] may in fact be a prerequisite for a significant induction of ${ }^{\circ} \mathrm{OH}$-mediated DNA strand breakage and C-8 oxidation of deoxyguanosine $[26,32-35,48,49]$ by quartz particles in epithelial cells. In our present study, 
the significance of ${ }^{\circ} \mathrm{OH}$ in the induction of DNA damage by quartz in epithelial cells was clearly established from two independent observations. On the one hand, the hydroxyl radical scavengers DMSO, mannitol, and TMTU (not shown) were able to reduce DNA strand breakage elicited by quartz. On the other hand, immunocytochemical analysis clearly demonstrates the induction of the ${ }^{\circ} \mathrm{OH}$-specific lesion $8-\mathrm{OHdG}$ in epithelial cells upon treatment with quartz. Although immunohistochemistry for 8-OHdG only allows semiquantitative analysis of the formation of these DNA adducts, alternative approaches have been criticised for the possible introduction of artefacts during the DNA isolation procedure [50]. This aspect may be even more crucial with regard to the evaluation of quartz, where radical generating properties of particles firmly attached to- or ingested by treated cells could possibly induce $8-\mathrm{OHdG}$ during cell processing. Although the occurrence of artificially introduced DNA breakage during cell processing is less likely for the comet assay based on the kinetics of strand breakage assays with quartz and naked DNA [6,12], this aspect also deserves future investigation. The fact that the ${ }^{\circ} \mathrm{OH}$ scavengers were not completely effective in blocking DNA strand breakage by quartz, is in line with previous observations with hydrogen peroxide, and has been explained by the extremely high reactivity of this radical in relation to the relative concentrations of the scavengers versus nucleotides in the nucleosome [32]. However, the non-optimal effectiveness of both scavengers may to some extent also be indicative of "OH-independent mechanisms of DNA strand breakage.

In conclusion, we demonstrate that respirable quartz particles elicit DNA damage in rat and human epithelial lung cells. Our data also indicate that ${ }^{\circ} \mathrm{OH}$-generating properties of the quartz particles are involved in the induction of these in vitro effects. The enhanced formation of $8-\mathrm{OHdG}$, as observed in the lungs of rats treated with quartz has been attributed to the excessive and persistent formation of ROS by neutrophils upon quartz-induced lung inflammation [17,21], a concept which is further supported from our present and earlier [23] in vitro observations with hydrogen peroxide. However, our current data also provide evidence for an inflammation-independent induction of DNA damage by quartz in epithelial cells. Whether these hydroxyl radical-generating properties of quartz particles contribute to DNA damage in vivo, and in turn whether this significantly impacts on mutagenesis and tumorigenesis as observed in chronic inhalation studies in rats $[1,18,19,51]$ still needs to be evaluated.

\section{Acknowledgements}

This study was supported by the Silikosegesellschaft Nordrhein Westfalen.

\section{References}

1. International Agency for Research on Cancer (IARC). Monograph on the Evaluation of the Carcinogenic Risk of Chemicals to Humans, Vol. 68: silica, some silicates, coal dust and para-aramid fibrils. IARC Press, Geneva, 1997.

2. Vallyathan V, Shi X, Dalal NS, Irr W, Castranova V. Generation of free radicals from freshly fractured silica dust: potential role in acute silica-induced lung injury. Am Rev Respir Dis 138: 1213-1219, 1988.

3. Fubini B. Giamello E, Volante M, Bolis V. Chemical functionalities at the silica surface determining its reactivity when inhaled. Formation and reactivity of surface radicals. Toxicol Ind Health 6: 571-598, 1990.

4. Shi X, Mao Y, Daniel LN. Saffiotti U, Dalal NS, Vallyathan V. Silica radical -induced DNA damage and lipid peroxidation. Environ Health Perspect 102 (suppl 10): 149-154, 1994.

5. Fubini B, Bolis V, Cavenago A, Volante M. Physicochemical properties of crystalline silica dusts and their possible implication in various biological responses. Scand J Work Environ Health 21 (Suppl 2): 9-14, 1995.

6. Daniel LN, Mao Y. Wang TC, Markey CJ. Shi X, Saffiotti U. DNA strand breakage, thymine glycol production, and hydroxyl radical generation induced by different samples of crystalline silica in vivo. Environ Res 71: 60-73, 1995.

7. Fubini B. Health effects of silica. In Legand AP (Ed.) The Surface Properties of Silica, John Wiley and Sons, New York, pp. 415-464, 1998.

8. Shi X, Castranova V, Halliwell B, Vallyathan V. Reactive oxygen species and silica-induced carcinogenesis. $J$ Toxicol Environ Health part B1: 181-197, 1998.

9. Donaldson K. Borm PJA. The quartz hazard: a variable entity. Ann Occup Hyg 42: 287-294, 1998.

10. Fubini B. Surface chemistry and quartz hazard. Ann Occup Hyg 42:521-530, 1998. 
11. Saffiotti U, Daniel LN, Mao Y, Shi X, Williams AO, Kaighn ME. Mechanisms of carcinogenesis by crystalline silica in relation to oxygen radicals. Environ Health Perspect 102 (Suppl 10): 159-163, 1994.

12. Daniel LN, Mao Y, Saffiotti U. Oxidative DNA damage by crystalline silica. Free Radic Biol Med 14: 463-472, 1993.

13. Daniel L.N, Mao Y. Saffiotti U. Direct interaction between crystalline silica and DNA - a proposed model for silica carcinogenesis. Scand J Work Environ Health 21 (Suppl 2):22-26, 1995.

14. Cheng KC, Cahill DS, Kasai H. Nishimura S, Loeb LA. 8-Hydroxyguanine, an abundant form of oxidative DNA damage, causes $G$ to $T$ and $A$ to $C$ substitutions, $J$ Biol Chem 267: 166-172, 1992.

15. Yamano Y, Kagawa J, Hanaoka T, Takahashi T, Kasai H, Tsugane S, Watanabe S. Oxidative DNA damage induced by silica in vivo. Emviron Res 69: 102-107, 1995.

16. Nehls P, Seiler F, Rehn B, Greferath R, Bruch J. Formation and persistence of 8-oxoguanine in rat lung cells as an important determinant for tumor formation following particle exposure. Environ Health Perspect 105: 1291-1296, 1997.

17. Seiler F, Rehn B, Rechn S, Bruch J. Quartz exposure of the rat lung leads to a linear dose response in inflammation but not in oxidative DNA damage and mutagenicity. Am J Respir Cell Mol Biol 24: 492-498, 2001.

18. Johnson NF. Smith DM, Sebring R. Holland LM. Silica-induced alveolar cell tumors in rats. Am J Ind Med 11: 93-107. 1987.

19. Driscoll KE, Deyo LC, Carter JM, Howard BW, Hassenbein DG, Bertram TA. Effects of particle exposure and particle-elicited inflammatory cells on mutation in rat alveolar epithelial cells. Carcinogenesis 18: 423-430, 1997

20. Borm PJA, Driscoll KE. Particles, inflammation and respiratory tract carcinogenesis. Toxicol Lett 88: 109-113, 1996.

21. Greim H, Borm P. Schins R, Donaldson K. Driscoll K. Hartwig A. Kuempel E, Oberdôrster G, Speit G. Toxicity of fibers and particles. Report of a workshop held in Munich, Germany, Inhal Toxicol 13: 737-754, 2001.

22. Driscoll KE, Deyo I.C. Howard BW, Poynter J, Carter JM. Characterizing mutagenesis in the hprt gene of rat alveolar epithelial cells. Exp Lung Res: 21, 941-956, 1995

23. Knaapen AM, Seiler F, Schilderman PAEL, Nehls P, Bruch J, Schins RPF, Borm PJA. Neutrophils cause oxidative DNA damage in alveolar epithelial cells. Free Radic Biol Med 27: 234-240, 1999.

24. Hesterberg TW, Barrett JC. Dependence of asbestos- and mineral dust-induced transformation of mammalian cells in culture on fiber dimension. Cancer Res 44:2170-2180, 1984

25. Nagalakshmi R. Nath J. Ong T. Whong WZ. Silica-induced micronuclei and chromosomal aberrations in Chinese hamster lung (V79) and human lung (Hel 299) cells. Mutat Res 335: 27-33, 1995.

26. Singh NP. MeCoy MT, Tice RR. Schneider EI. A simple technique for quantitation of low levels of DNA damage in individual cells. Exp Cell Res 175: 184-191, 1988.

27. Olive PL, Banath JP, Durand RE. Heterogeneity in radiation-induced DNA damage and repair in tumor and normal cells measured using the "comet" assay. Radiat Res 122:86-94, 1990.

28. Tice RR, Agurell E, Anderson D. Burlinson B. Hartmann A. Kobayashi H. Miyamae Y. Rojas E, Ryu JC, Sasaki YF. Single cell gel/comet assay: guidelines for in vitro and in vivo genetic toxicology testing. Emviron Mol Mutagen 35 206-221, 2000.

29. Zhong BZ, Whong WZ, Ong TM. Detection of mineral-dust-induced DNA damage in two mammalian cell lines using the alkaline single cell gel/comet assay. Mutat Res 393: 181-187, 1997.

30. Liu X, Keane MJ. Harrison JC, Cilento EV, Ong T, Wallace WE. Phospholipid surfactant adsorption by respirable quartz and in vitro expression of cytotoxicity and DNA damage. Toxicol Lett 96-97: 77-84, 1998.

31. Thang Z, Shen HM. Zhang QF, Ong CN. Critical role of GSH in silica-induced oxidative stress, cytotoxicity, and genotoxicity in alveolar macrophages. Am J Phsiol 277: 1.743-1.748, 1999.

32. Schraufstaitter I, Hyslop PA, Jackson JH, Cochrane CG. Oxidant-induced DNA damage of target cells. J Clin Imvest 82: 1040-1050, 1988.

33. Spencer JP, Jenner A. Chimel K. Aruoma OI. Cross CE, Wu R, Halliwell B. DNA strand breakage and base modification induced by hydrogen peroxide treatment of human respiratory tract epithelial cells. FEBS Lett $374: 233$ 236,1995 .

34. Churg A, Keeling B, Gilks B, Porter S, Olive P. Rat mesothelial and tracheal epithelial cells show equal DNA sensitivity to hydrogen peroxide-induced oxidant injury. Am J Phsiol 268: L.832-1.838, 1995

35. Henle ES, I inn S. Formation, prevention, and repair of DNA damage by iron hydrogen peroxide. $J$ Biol Chem 272 19095.19098, 1997

36. Mechan WJ, Spencer JP, Rannels DE, Welch DR, Knobbe ET, Ostrander GK. Hydrogen peroxide induces oxidative DNA damage in rat type II pulmonary epithelial cells. Emviron Mol Mutagen 33: 273-278, 1999

37. Brown DM, Wilson MR, MacNee W. Stone V. Donaldson K. Size-dependent proinflammatory effects of ultrafine polystyrene particles: a role for surface area and oxidative stress in the enhanced activity of ultrafines. Toxicol Appl Pharmacol 175: 191-199, 2001.

38. Tovokuni S, Tanaka T. Hattori Y. Nishiyama Y, Yoshida A. Uchida K. Hiai H. Ochi H. Osawa T. Quantitative immunohistochemical determination of 8 -hydroxy-2'-deoxyguanosine by a monoclonal antibody N45.1: Its application to ferric nitrolotriacetate-induced renal carcinogenesis model. Lab Imest 76: 365-374, 1997

39. Hlia MC, Storer RD, McKelvey TW, Kraynak AR, Barnum JE, Harmon LS, Deluca JG, Nichols WW: Rapid DNA degradation in primary rat hepatocytes treated with diverse cytotoxic chemicals: Analysis by pulsed field gel electrophoresis and implications for alkaline elution assays. Environ Mol Mutagen 24: 181-191. 1994.

40. Schins RPF. Mechanisms of genotoxicity of particles and fibres. Inhal Toxicol 14:57-78, 2002

41. I ieber M. Smith B, Srakal A. Nelson-Rees W. Todaro G. A continuous tumor-cell line from a human lung carcinoma with properties of tope II alveolar epithelial cells. Int J Cancer 17:62-70, 1976. 
42. Driscoll KE, Carter JM, lype PT, Kumari HL, Crosby LL, Aardema MJ, Isfort RJ, Cody D, Chestnut MH, Le Boeuf RA. Establishment of immortalized alveolar type II epithelial cell lines from adult rats. In Vitro Cell Dev Biol Anim 31: 516-527, 1995.

43. Stearns RC, Paulauskis JD, Godleski JJ. Endocytosis of ultrafine particles by A549 cells. Am J Respir Cell Mol Biol 24: 108-115, 2001.

44. Brody AR, Roe MW, Evans JN, Davis GS. Deposition and translocation of inhaled silica in rats. Quantification of particle distribution, macrophage participation, and function. Lab Imvest 47: 533-542, 1982.

45. Churg A. The uptake of mineral particles by pulmonary epithelial cells. Am J Respir Crit Care Med 154: 1124-1140, 1996.

46. Kinnula VL, Everitt J, Whorton AR, Crapo JD. Hydrogen peroxide production by alveolar type II cells, alveolar macrophages, and endothelial cells. Am J Physiol 261: L.84-L.91, 1991.

47. Van Klaveren RJ, Roelant C, Boogaerts M, Demedts M, Nemery B. Involvement of an NAD(P)H oxidase-like enzyme in superoxide anion and hydrogen peroxide generation by rat type II cells. Thorax 52: 465-471, 1997.

48. Pryor WA. Why is the hydroxyl radical the only radical that commonly adds to DNA? Free Radic Biol Med 4:219. 223, 1988

49. Marnett LJ. Oxyradicals and DNA damage. Carcinogenesis 21: 361-370, 2000.

50. Xu A, Wu LJ, Santella RM, Hei TK. Role of oxyradicals in mutagenicity and DNA damage induced by crocidolite asbestos in mammalian cells. Cancer Res 59: 5922-5926, 1999.

51. Johnston CJ, Driscoll KE, Finkelstein JN, Baggs R, O'Reilly MA, Carter J, Gelein R, Oberdorster G. Pulmonary chemokine and mutagenic responses in rats after subchronic inhalation of amorphous and crystalline silica. Toxicol Sci 56: 405-413, 2000. 


\section{Part 2}

Secondary genotoxicity 


\title{
Chapter 5
}

\section{Neutrophils cause oxidative DNA damage in alveolar epithelial cells}

\author{
Ad M Knaapen', Frank Seiler ${ }^{2}$, Pauline AEL Schilderman', Peter Nehls², Joachim Bruch², \\ Roel PF Schins', and Paul JA Borm'
}

${ }^{1}$ Department of Health Risk Analysis and Toxicology, Maastricht University, Maastricht, The Netherlands. ${ }^{2}$ Institute of Hygiene and Occupational Medicine,

University of Essen, Medical School, Germany

\begin{abstract}
Inflammation has been recognised as a contributing factor in the pathogenesis of some cancers. In the rat lung, particle-induced inflammation is characterised by an influx of polymorphonuclear neutrophils (PMN) that release a variety of reactive oxygen species (ROS). The aim of the present study was to investigate direct effects of PMN on oxidative DNA damage in specific target cells for particle-induced lung carcinogenesis. Therefore, rat alveolar epithelial cells (RLE) were coincubated with PMN or hydrogen peroxide. Known to be closely associated with carcinogenesis, 8-hydroxydeoxyguanosine (8-OHdG) was used as an effect marker for oxidative DNA damage. Viability of the RLE cells, when coincubated with PMN decreased to $40 \%$, dependent on the ratio between PMN and RLE. After washing off coincubated PMN, 8-OHdG levels in the RLE cells were significantly increased, although the highest levels were observed in the washed off PMN fraction. In addition, to avoid washing procedures, immunohistochemical analysis was used to measure $8-\mathrm{OHdG}$ on a single cell level specifically in RLE cells, and similar results were obtained. Moreover, inhibitor experiments showed that the DNA-damage as observed in coincubations was reduced by the addition of anti-oxidants. In conclusion, our data provide evidence that $\mathrm{H}_{2} \mathrm{O}_{2}$ as well as ROS released by PMN, cause oxidative DNA damage in alveolar epithelial lung cells. Whether this process is involved in inflammation-related carcinogenesis during particle exposure remains to be elucidated.
\end{abstract}

Based on: Free Radical Biology \& Medicine 27: 234-240, 1999. 


\section{Introduction}

There is evidence that reactive oxygen species (ROS) play an important role in the relationship between inflammation and carcinogenesis (1-4). In the lung, alveolar and bronchial epithelial cells are exposed to a variety of ROS from both exogenous (e.g. ozone, cigarette smoke, asbestos) and endogenous sources, such as from the inflammatory phagocyte respiratory burst. Inflammatory processes are thought to play a major role in the pathogenesis associated with the inhalation of poorly soluble particles such as titanium dioxide, carbon black or diesel soot $(5,6)$. In the rat, such particle-induced inflammatory response is characterised by a marked recruitment and subsequent activation of inflammatory phagocytes, including polymorphonuclear neutrophils (PMN). Increased generation and release of ROS such as superoxide $\left(\mathrm{O}_{2}{ }^{\circ}\right)$, hydroxyl radicals $\left(\mathrm{HO}^{\circ}\right)$, hydrogen peroxide $\left(\mathrm{H}_{2} \mathrm{O}_{2}\right)$, and the myeloperoxidase (MPO)-catalysed production of hypochlorous acid $(\mathrm{HOCl})$ is a characteristic of activated PMN (7). These ROS can influence the carcinogenic process in several ways, including by the modulation of genes that regulate cell growth and proliferation $(8,9)$, and by the induction of structural DNA damage in target cells $(1,3,10)$. Especially hydrogen peroxide and hydroxyl radicals are thought to play an important role in phagocyte-induced DNA damage. For instance, $\mathrm{H}_{2} \mathrm{O}_{2}$ is reported to cause ${ }^{\circ} \mathrm{OH}$-mediated DNA single strand breaks in various target cells $(3,11)$. Moreover, increased levels of $\mathrm{H}_{2} \mathrm{O}_{2}$ were found in exhaled air of patients with pulmonary inflammatory diseases such as chronic obstructive pulmonary disease (COPD) (12). An indication that these inflammation-associated ROS may also be genotoxic in humans is provided by observations on the induction of oxidative damage in nude DNA by bronchoalveolar lavage (BAL) fluid obtained from COPD patients (13).

In the rat, particle-induced recruitment of PMN has been related to the induction of mutagenic effects in the HPRT gene of pulmonary epithelial target cells $(10,14)$. Further in vitro experiments using $\mathrm{BAL}$ cells from quartz-exposed rats indicated that PMN were much more mutagenic to cocultured alveolar epithelial cells than alveolar macrophages. Moreover, the mutagenic effects caused by PMN could be inhibited by the addition of catalase (10), indicating a role PMN-derived ROS, especially $\mathrm{H}_{2} \mathrm{O}_{2}$. Interestingly, these data could possibly be linked to other recent in vivo studies, reporting an induction of the premutagenic oxidative DNA adduct 8-hydroxydeoxyguanosine (8-OHdG) in lung cells of quartz-exposed rats. Although this effect appeared to be related to an influx of inflammatory phagocytes (15), the capacity of PMN to induce 8-OHdG specifically in alveolar epithelial target cells has not yet been studied.

The aim of our study was to investigate the direct effect of ROS production by PMN on oxidative DNA damage in rat alveolar type II epithelial cells (RLE), which is the specific lung target cell from which particle-induced rat lung tumours are thought to be derived $(5,10)$. Therefore, we applied an in vitro model of lung inflammation, previously used to demonstrate that activated PMN convert polycyclic aromatic hydrocarbons to DNA binding metabolites in rat alveolar epithelial cells (16). In the present study this model, a coincubation of RLE with $\mathrm{PMN}$ or hydrogen peroxide, was used to evaluate PMN-induced oxidative DNA damage in these lung target cells. We used 8-OHdG, a premutagenic DNA lesion which is strongly associated with the carcinogenic process (17), as a specific effect marker for ROS-induced DNA damage. Both HPLC-ECD and immunohistochemistry were applied to detect 8-OHdG in either target cells or PMN. 


\section{Materials and Methods}

\section{Chemicals}

Phorbol-12-myristate-13-acetate (PMA) and 3-(4,5-dimethylthiazol-2-yl)-2,5-diphenyltetrazolium bromide (MTT) were purchased from Sigma (St. Louis, MO). Ham's F12, Hanks' Balanced Salt Solution (HBSS), foetal calf serum (FCS), HEPES buffer and trypsin-EDTA were purchased from Gibco/Life Technologies (Breda, The Netherlands). Lymphoprep was obtained from Nycomed (Oslo, Norway). TRITC-conjugated goat-anti rabbit antibody was obtained from Dianova (Hamburg, Germany). Superoxide dismutase (SOD) and catalase (Cat) were purchased from Boehringer (Mannheim, Germany). $\mathrm{H}_{2} \mathrm{O}_{2}$, DMSO and all other chemicals were purchased from Merck (Darmstadt, Germany).

\section{Cell culture and (co)incubations}

Immortalised rat lung alveolar type II cells (RLE) (18) were grown at $37^{\circ} \mathrm{C}$ in Ham's F12 medium supplemented with 1\% 1M HEPES buffer and $5 \%$ heat inactivated Foetal Calf Serum (FCS). Cells were used at near confluency. PMN were freshly isolated from the blood of one healthy non-smoking male volunteer using gradient centrifugation (19). Lymphocytes were removed and to the lowest layer, containing PMN and erythrocytes, cold lysis buffer (155 $\mathrm{mM} \mathrm{NH}_{4} \mathrm{Cl}, 10 \mathrm{mM} \mathrm{KHCO} 3,10 \mathrm{mM}$ EDTA, pH 7.4) was added to lyse the contaminating erythrocytes. PMN were suspended in Hanks' Balanced Salt Solution (HBSS) and counted using a Bürker chamber. Viability was tested by means of Trypan Blue dye exclusion $(0.4 \%)$. PMN and solutions were kept on ice to avoid premature activation. This method consistently yielded PMN with a viability $>95 \%$. For the experiments, nearly confluent monolayers of RLE cells, grown in $175 \mathrm{~cm}^{2}$ culture flasks, were used. Medium was discarded and HBSS (25 $\mathrm{ml}$ ) supplemented with the PMN was added. For the coincubations equal numbers of RLE and PMN were used (1:1 ratio). PMN were activated by phorbol-12-myristate-13-acetate (PMA, $100 \mathrm{ng} / \mathrm{ml}$ ). RLE cells were exposed to PMN for 2 hours at $37^{\circ} \mathrm{C}$. Control incubations were without $\mathrm{PMN}$ and/or without PMA. After incubation, PMN were washed off using three times $10 \mathrm{ml}$ of cold $\left(4^{\circ} \mathrm{C}\right)$ HBSS. To check this procedure, coincubations were run in parallel on Lab Tek II 2-chamber slides (Nunc, Life technologies). PMN were washed off and cells still adherent on the slides were fixed, stained with Diff Quick and differentiated microscopically. Using this methodology, the wash off procedures proved to be efficient $(3.0 \pm 0.9 \% \mathrm{PMN}$ left). PMN and RLE cell fractions were centrifuged and stored at $-20^{\circ} \mathrm{C}$ until analysis. To specifically investigate the role of $\mathrm{H}_{2} \mathrm{O}_{2}$, as it is a crucial PMN-derived ROS (3), RLE cells were exposed to increasing amounts of $\mathrm{H}_{2} \mathrm{O}_{2}(0-100 \mu \mathrm{M})$ suspended in HBSS. After two hours cells were harvested as described above. Cytotoxicity of PMA, PMN and $\mathrm{H}_{2} \mathrm{O}_{2}$ in RLE was tested by the MTT colometric assay according to Mosmann (20) and Dong (21), and which was described previously (16).

To investigate the effects of specific antioxidants on the PMN-induced oxidative DNA damage, catalase $(5000 \mathrm{U} / \mathrm{ml})$ and/or superoxide dismutase (SOD, $2500 \mathrm{U} / \mathrm{ml}$ ) were added to coincubations of RLE with PMA-activated PMN. Coincubations were performed as described above. After $2 \mathrm{~h}$ incubation, unseparated cells were harvested by gentle scraping, centrifuged and stored at $-20{ }^{\circ} \mathrm{C}$ without further separation.

\section{DNA isolation and HPLC-ECD analysis}

Harvested cells were lysed overnight at $37^{\circ} \mathrm{C}$ in $5 \mathrm{ml} \mathrm{NEP} / \mathrm{SDS}$ solution $(75 \mathrm{mM} \mathrm{NaCl}, 25$ $\mathrm{mM}$ EDTA, $50 \mu \mathrm{g} / \mathrm{ml}$ proteinase $\mathrm{K}, 1 \%$ SDS). DNA from PMN and RLE was isolated as described previously (22). The DNA was dissolved in $5 \mathrm{mM}$ Tris- $\mathrm{HCl}(\mathrm{pH} \mathrm{7.4)}$ at a final concentration of $0.5 \mathrm{mg} / \mathrm{ml}$. Oxidative DNA damage was measured using high performance liquid chromatography with electrochemical detection (HPLC-ECD), according to Floyd (23), 
as described previously (22), and was expressed as the ratio of $8-\mathrm{OHdG}$ to deoxyguanosine (dG).

\section{Immunohistochemistry}

To evaluate possible artefacts introduced by the washing-off procedures, immunohistochemistry was used to evaluate $8-\mathrm{OHdG}$ formation on a single cell level specifically in the RLE cells. Therefore, cells were seeded in Lab Tek II 2-chamber slides (Nunc, Life Technologies), with a surface of $4 \mathrm{~cm}^{2}$. At near confluency, the medium was discarded, replaced by HBSS and cells were exposed to PMN (1:1 ratio with RLE). Hydrogen peroxide was used as a positive control for 8-OHdG induction. After incubation for two hours at $37^{\circ} \mathrm{C}$ slides were washed once in PBS $\left(37^{\circ} \mathrm{C}\right)$ without further rinsing the adherent PMN, fixed for 30 minutes in $70 \%$ ethanol and stored at $-80^{\circ} \mathrm{C}$. Immunohistochemical analysis of 8 $\mathrm{OHdG}$ was performed as described by Seiler et al (24). Briefly: Slides were rehydrated in $2 \mathrm{x}$ SSC ( $300 \mathrm{mM} \mathrm{NaCl}, 30 \mathrm{mM}$ sodium citrate, $\mathrm{pH} \mathrm{7.4)}$ and treated with RNAses (RNAse A, $200 \mu \mathrm{g} / \mathrm{ml}$ and RNAse T1, 50 units $/ \mathrm{ml}$ ) for 1 hour at $37^{\circ} \mathrm{C}$. The samples were denaturated for 5 minutes at $4{ }^{\circ} \mathrm{C}(70 \mathrm{mM} \mathrm{NaOH}, 0.14 \mathrm{M} \mathrm{NaCl}$, dissolved in $40 \%$ ethanol). Samples were neutralised in PBS and Proteinase $\mathrm{K}\left(2 \mu \mathrm{g} / \mathrm{ml}, 10\right.$ minutes at $\left.37^{\circ} \mathrm{C}\right)$ was used to denature DNA-associated proteins. After blocking with PBS $/ 20 \%$ BSA for 20 minutes the slides were incubated overnight at $4{ }^{\circ} \mathrm{C}$ with the first antibody (rabbit anti-8-OHdG) (15), and subsequently incubated for 45 minutes at $37^{\circ} \mathrm{C}$ with goat anti rabbit $\mathrm{F}(\mathrm{ab}) 2$-fragment labeled with rhodamine isothiocyanate (TRITC, Dianova, Hamburg, Germany, $2 \mu \mathrm{g} / \mathrm{ml}$ in PBS $/ 1 \%$ BSA). The specificity of the antibody was shown previously by comparing its affinity constant $\left(K_{A}\right)\left(4.2 \times 10^{8}\right)$ with other (un)modified DNA/RNA-constituents including 8-OHguanosine $\left(2.1 \times 10^{8}\right)$, deoxyguanosine $\left(1.0 \times 10^{6}\right)$, and guanosine $\left(1.0 \times 10^{6}\right)$ by competitive radioimmunoassay (15). Moreover, binding of the antibody was shown to be restricted and specific for DNA in lung tissue sections (15). The nuclear DNA was counterstained with DAPI (4,6-diamino-2-phenylindole, $0.3 \mu \mathrm{M}$ in PBS, pH 8.2). Fluorescence was visualised using fluorescence microscopy (Zeiss Axiovert $135 \mathrm{TV}$, Oberkochen, Germany) and quantitated by a multiparameter image analysis system (Camera: Hamamatsu, Japan, ACAS image analysis systems, $\mathrm{O}$. Ahrens, Bargteheide, Germany). On each slide, at least 100 cells were counted. The TRITC signals were corrected for the corresponding DAPI-DNA fluorescence and expressed as relative fluorescence units (RFU). In the coincubations, fluorescence signals were measured specifically in the RLE cells. Slides were stained with Diff Quick after fluorescence visualisation and the number of contaminating PMN still attached on the slides was counted and never exceeded $3.5 \%$ of total cells.

\section{Statistical analysis}

Results are expressed as mean \pm standard deviation. Spearman Rank correlation was used to examine the dose response between $\mathrm{H}_{2} \mathrm{O}_{2}$ and $8-\mathrm{OHdG}$. Differences between groups were determined using Mann-Whitney. Differences were considered to be statistically significant when $\mathrm{p}<0.05$. 


\section{Results}

\section{Cytotoxicity}

Cytotoxicity assays indicated that exposure to hydrogen peroxide up to concentrations of 100 $\mu \mathrm{M}$ was not toxic to RLE $(<13 \%$ at $100 \mu \mathrm{M})$. However, at $500 \mu \mathrm{M}$ cytotoxicity was nearly $100 \%$ (Figure 1a). Coincubated non-stimulated PMN were not cytotoxic to RLE cells. However, when coincubated PMN were activated with PMA $(100 \mathrm{ng} / \mathrm{ml})$, the viability of the RLE significantly decreased to $69 \%$ at a ratio between PMN and RLE of $1: 1$ (Figure lb). This was further decreased to $43 \%$ at a ratio of $5: 1$. This effect was unlikely due to a direct action of PMA on the target cells, since PMA alone at a concentration of $100 \mathrm{ng} / \mathrm{ml}$ was not cytotoxic to RLE.

A

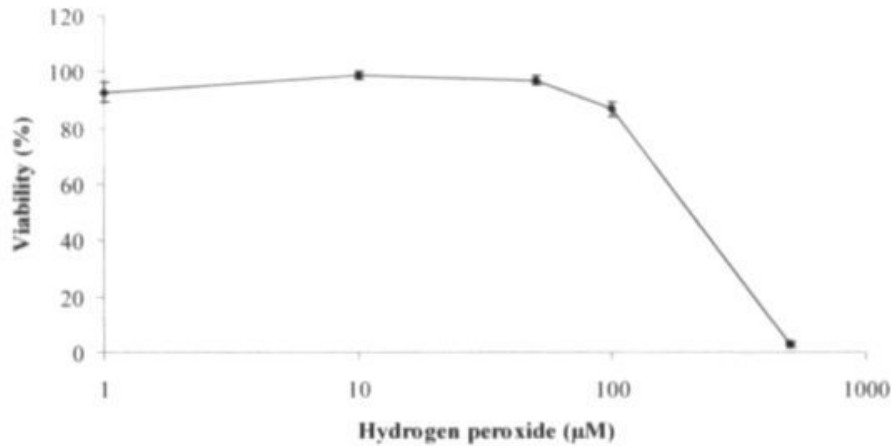

B

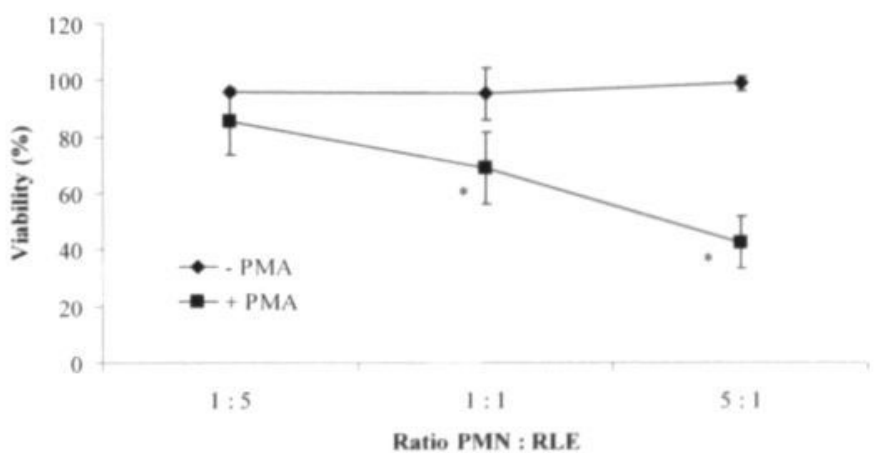

Figure 1. A) Viability of RLE cells incubated for $2 \mathrm{~h}$ with hydrogen peroxide (1-500 $\mu \mathrm{M})$. Viability was tested using MTTcytotoxicity assay. Data are expressed as mean $\pm s d(n=2)$.

B) Viability of RLE incubated for $2 \mathrm{~h}$ with activated or non-activated human PMN. Activation of PMN was performed by PMA $(100 \mathrm{ng} / \mathrm{ml})$. PMN were washed off before measuring the viability. Data are expressed as mean \pm sd $(\mathrm{n}=3)$. Significantly decreased compared to RLE coincubated with non-stimulated PMN ( $p<0.05)$. 


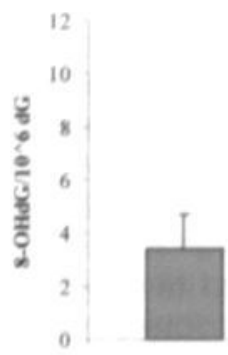

0

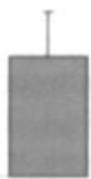

10

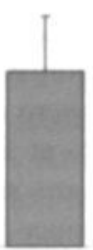

50

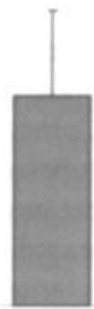

100

Hydrogen peroside ( $\mu \mathrm{M})$

Figure 2. 8-OHdG in RIE (n - 4) after incubation with hydrogen peroxide $(0-100 \mu \mathrm{M})$. $8-\mathrm{OHdG}$ was measured using HPI.C.FCD and is presented as the number of $8-0 H$ HG residues per $10^{6}$ deoxyguanosine (dG). 8-OHdG levels increase with hydrogen peroxide concentrations (Spearman: $r=0.71, p<0.05$ ).
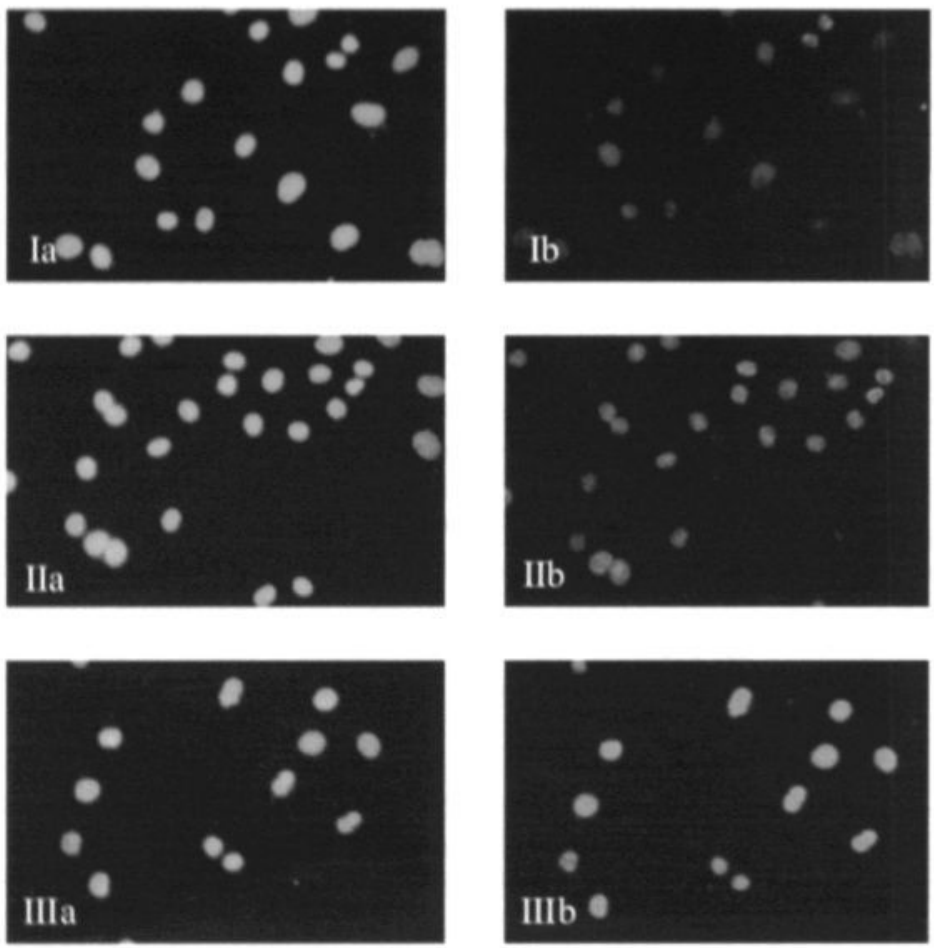

Figure 3. Visualisation of 8 -OHldGi fluorescence in RI F cells after exposure for $2 \mathrm{~h}$ to $\mathrm{H}, \mathrm{O}$. Ia, Ila, IIla) Fluorescence of DNA after staining with D) $\mathrm{Pl}$ : Ib, IIb. IIIb) Corresponding 8 -OHdG fluorescence. Cells were exposed to (I) $0 \mu \mathrm{M} \mathrm{H}-\mathrm{O}$, (62 Relative fluorescence units, RF(1), (II) $10 \mu \mathrm{M} \mathrm{H.O.} \mathrm{(97} \mathrm{RFI')} \mathrm{and} \mathrm{(III)} 50 \mu \mathrm{M} \mathrm{H.O.2(120} \mathrm{RF(1).} \mathrm{Pictures} \mathrm{were} \mathrm{taken} \mathrm{at} 500 x$ magnification. Immunohistochemical analysis and visualisation was performed as described in Materials and Methods section. 


\section{Oxidative DNA damage}

To investigate the ability of $\mathrm{H}_{2} \mathrm{O}_{2}$ to induce oxidative DNA damage, RLE cells were incubated for 2 hours with increasing concentrations of $\mathrm{H}_{2} \mathrm{O}_{2}$ (Figure 2). The 8-OHdG levels, determined by HPLC-ECD, were dose-dependently increased (Spearman, $\mathrm{p}<0.05$ ) to an absolute level of $8.8 \pm 3.0$ per $10^{6} \mathrm{dG}$ at $100 \mu \mathrm{M} \mathrm{H}_{2} \mathrm{O}_{2}$. Similar results were obtained using immunohistochemistry (Figure 3 ).

Table 1. Oxidative DNA damage in RLE coincubated for $2 \mathrm{~h}$ with PMN (1:1 ratio).

\begin{tabular}{|c|c|c|c|}
\hline RLE (background) & Coincubations & RLE* & $\mathrm{PMN} *$ \\
\hline $3.4 \pm 1.3$ & $\begin{array}{l}\text { - PMA } \\
+ \text { PMA }\end{array}$ & $\begin{array}{l}7.9 \pm 2.0^{a} \\
8.5 \pm 4.7^{a}\end{array}$ & $\begin{array}{c}7.6 \pm 2.9 \\
16.8 \pm 6.6^{b}\end{array}$ \\
\hline
\end{tabular}

Data are mean $\pm \mathrm{SD}(\mathrm{n}=6)$ and are expressed as 8-OHdG per $10^{6} \mathrm{dG}$. $\bullet$ RLE and PMN were separated after coincubation.

"significantly different from RLE background $(\mathrm{p}<0.05),{ }^{6}$ significantly different from unstimulated $\mathrm{PMN}(\mathrm{p}<0.01)$.

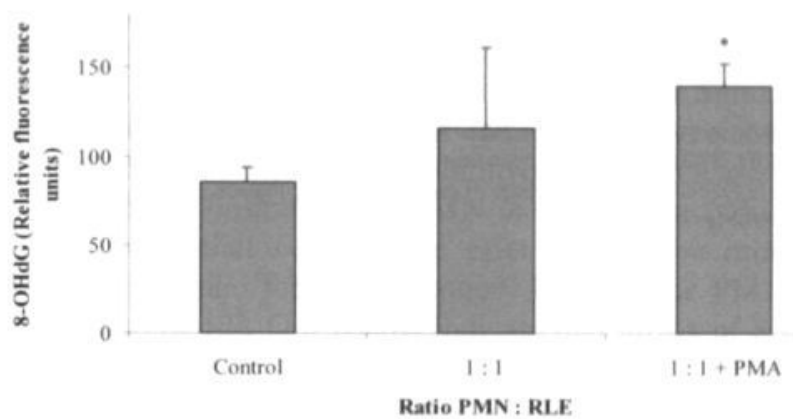

Figure 4. Oxidative DNA damage in RLE $(n=4)$ after incubation with PMN. 8-OHdG was analysed using immunohistochemistry and is expressed as relative fluorescence units of 100 cells/sample. Only fluorescence levels measured specifically in RLE are shown. Activation of PMN was done by PMA.

* Significantly increased compared to RLE (Control) ( $\mathrm{p}<0.05)$.

To investigate the ability of PMN to induce oxidative DNA damage in RLE, we incubated RLE for $2 \mathrm{hr}$ with an equal number of PMN. The 8-OHdG levels were measured in RLE by HPLC/ECD after washing off the PMN and were significantly increased to $7.9 \pm 2.0$ per $10^{6} \mathrm{dG}(\mathrm{p}<0.05)$, compared with control incubations (Table I). Activation of the PMN with PMA further enhanced DNA-damage $\left(8.5 \pm 4.78-\mathrm{OHdG} / 10^{6} \mathrm{dG}\right)$. Control experiments demonstrated that PMA had no direct effect on $8-\mathrm{OHdG}$ levels in RLE. The 8-OHdG level in the washed off, unstimulated PMN fraction was $7.6 \pm 2.9$ per $10^{6} \mathrm{dG}$ and was significantly increased to $16.8 \pm 6.6$ per $10^{6} \mathrm{dG}$ ( $\mathrm{p}<0.01$ ) in activated PMN (Table I). Since the wash off procedures could introduce an underestimation of the real $8-\mathrm{OHdG}$ level in the RLE, especially if non-viable RLE cells are lost, a specific antibody raised against 8-OHdG was used to investigate oxidative damage directly in the RLE on a single cell level, thereby avoiding washing off PMN. The background 8-OHdG level in the RLE measured using this antibody-assay was $85 \pm 9$ relative fluorescence units (RFU). This was increased to $116 \pm 46$ RFU when the target cells were exposed to PMN (1:1 ratio). A further, and significant 
enhancement of oxidative DNA damage (to $140 \pm 9$ RFU, $\mathrm{p}<0.05$ ) was seen when the PMN were activated with PMA (Figure 4).

Inhibitor experiments with specific antioxidant-enzymes showed that catalase $(5000$ $\mathrm{U} / \mathrm{ml}$ ) alone did not reduce oxidative DNA damage in non-separated coincubations, whereas SOD $(2500 \mathrm{U} / \mathrm{ml})$ reduced the formation of $8-\mathrm{OHdG}$ by $40 \%$. A combination of catalase and SOD gave a reduction of about $50 \%$ compared to coincubations without antioxidants (Figure 5).

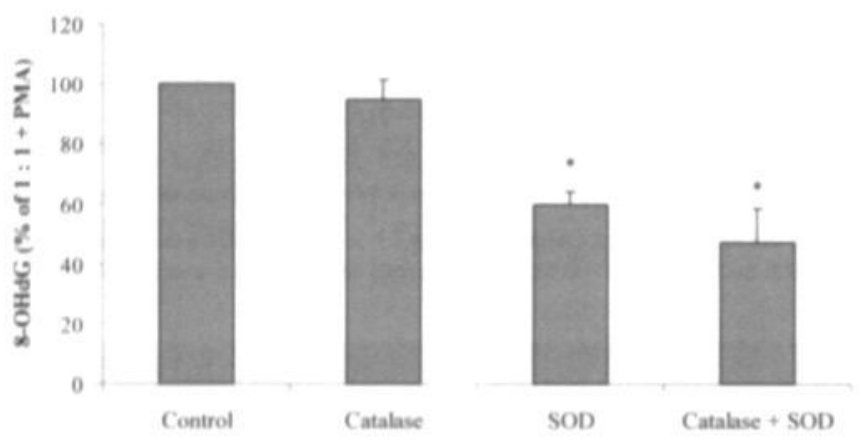

Figure 5. Oxidative DNA damage in coincubations of RLE and activated PMN (1 : 1) in the presence of anti-oxidant enzymes (catalase, $5000 \mathrm{U} / \mathrm{ml}$; SOD, $2500 \mathrm{U} / \mathrm{ml}$ ) alone or in combination. Oxidative DNA damage was determined by HPLC in unseparated cell-scrapings and is expressed as percentage of control (- coincubation + PMA, without anti-oxidants).

* Significantly different from control (p<0.05)

\section{Discussion}

The objective of this study was to investigate the direct cytotoxic and genotoxic effects of PMN on lung target cells using an in vitro model coincubating rat alveolar epithelial cells with freshly isolated human PMN. We showed that activated PMN induce injury to alveolar epithelial cells leading to loss a of viability which was related to the number of coincubated PMN. Furthermore, using HPLC/ECD and immunohistochemistry, we showed that PMN were able to cause formation of 8-OHdG in RLE, which is a specific and relative stable DNA lesion induced by hydroxyl radical attack of the guanine base $(23,25)$. No data are available on the DNA-repair capacity of this cell line (RLE), but Takeuchi et al. showed that the halflife of 8-OHdG in lung fibroblasts was about 6 hours (26). Therefore, it seems justified to assume that the 8-OHdG levels induced in RLE are not significantly affected by repair during the 2 hours incubation. Separate analysis of $8-\mathrm{OHdG}$ in the PMN showed that activation by PMA also enhanced oxidative DNA damage in the PMN itself, which is in accordance with Floyd et al (23). To avoid washing procedures we also used an antibody raised against 8OHdG to evaluate the oxidative DNA damage specifically in RLE after coincubation with PMN. Similar results compared to the HPLC/ECD analysis were observed, except for the background level of 8-OHdG in RLE, which seems relatively higher in samples analysed using immunohistochemistry. This difference may be explained by non-specific binding of the antibody, which has indeed a moderate cross-reactivity to unmodified guanine (15). Many candidate ROS may be involved in oxidative DNA damage in the RLE and PMN itself, including hypochlorous acid $(\mathrm{HOCl}), \mathrm{H}_{2} \mathrm{O}_{2}$ or peroxynitrite $\left(\mathrm{ONOO}^{\circ}\right)$, which is produced by the reaction of $\mathrm{NO}^{\circ}$ with $\mathrm{O}_{2}{ }^{*}$ (27). However, it is unclear which ROS released by PMN, is 
responsible for the induction of 8 -OHdG. The most likely candidate, the hydroxyl radical (23), is so reactive that when it is generated extracellularly it cannot reach the nucleus to induce damage. However, other studies using non-pulmonary target cells have suggested that extracellular $\mathrm{H}_{2} \mathrm{O}_{2}$ generated by $\mathrm{PMN}$ is able to diffuse through the membrane into the target cell, were it is responsible for the generation of ${ }^{\circ} \mathrm{OH}$ in direct vicinity of the DNA $(3,28,29)$. This is supported by our observations that extracellular reagent hydrogen peroxide induces the formation of the $\mathrm{OH}$ specific DNA lesion 8-OHdG in the RLE at levels at which no cytotoxicity is yet observed. On the other hand, in a mixture of RLE and PMN the involvement of other ROS (mainly $\mathrm{O}_{2}{ }^{-{ }^{*}}$ ) is suggested, since only SOD but not catalase is able to reduce oxidative DNA-damage in these samples. However, these data probably mainly reflect an effect of the anti-oxidants on the 8-OHdG levels in the PMN themselves, since these are shown to be $2 \mathrm{x}$ higher than in the RLE cells (Table 1). Although alveolar type II cells in vitro are relatively well protected against oxidant stress $(30,31)$, we showed that freshly isolated, and unstimulated PMN were able to induce 8-OHdG in these cells (Figure 4, Table 1). On the other hand, we also showed that PMN-induced loss of viability in epithelial cells was only observed after additional activation with PMA. This implies that freshly isolated, unstimulated PMN in vitro already release ROS leading to oxidative DNA damage in target cells. Moreover, it suggests that viability loss of RLE elicited by PMN is not simply the result of ROS release, but also involves additional activation of the PMN, which is characterised by the adherence to the epithelial cell monolayer and subsequent release of proteolytic enzymes, such as lysosyme, collagenase and elastase leading to hydrolysis of cell walls and matrix degradation (32). This is supported by data of Simon et al (33) who showed that neutrophil-mediated killing of rat alveolar epithelial cells required tight adherence of the activated PMN to the epithelial cells and did not involve ROS released by the PMN.

In summary, we demonstrated that $\mathrm{PMN}$ in vitro cause induction of $8-\mathrm{OHdG}$ in the DNA of rat alveolar epithelial cells. These effects could be mimicked using hydrogen peroxide as a model compound for the respiratory burst of the PMN and the inflammatory status of diseased lungs (10-12). Our results indicate that influx of PMN in the lung poses a genotoxic risk to epithelial lung cells, because $8-\mathrm{OHdG}$, as an effect marker for oxidative DNA damage, is known to induce base mispairing leading to mutations (34). Moreover, our data are complementary to recent in vivo studies with rats, suggesting a role of PMN in alveolar epithelial oxidative DNA damage and mutagenesis after quartz exposure $(10,15)$. Future experiments will further concentrate on the implication and mechanism of PMNinduced oxidative DNA damage in lung target cells after particle exposure.

\section{Acknowledgements}

We acknowledge dr. Kevin E. Driscoll of the Procter \& Gamble company, Miami Valley Labs, Cincinnati $(\mathrm{OH})$ for providing the RLE cells. Furthermore, we thank Prof. Jos Kleinjans for critically reviewing the manuscript. 


\section{References}

I. Weitzman SA, Gordon L. Inflammation and cancer: role of phagocyte-generated oxidants in carcinogenesis. Blood 76: $655-663,1990$

2. Dungworth DL. Mohr U, Heinrich U, Emst H. Kittel B. Pathologic effects of inhaled particles in rat lungs: associations between inflammatory and neoplastic processes. In: Mohr. U (eds.) Toxic and carcinogenic effects of solid particles in the respiratory tract. Washington, IL.SI Press: 75-98, 1994.

3. Schraufstatter I, Hyslop PA, Jackson JH, Cochrane CG. Oxidant induced DNA damage of target cells. J Clin Imvest 82: 1040-1050, 1988.

4. Skillnud DM, Offord KP. Miller RD. Higher risk of lung cancer in chronic obstructive pulmonary disease: a prospective, matched, controlled study. Ann Internal Med 105: 503-507, 1986.

5. Nikula KJ, Snipes MP, Griffith WC, Henderson RF. Mauderly J. Comparative pulmonary toxicities and carcinogenicities of chronically inhaled diesel exhaust and carbon black in F344 rats. Fundam Appl Toxicol 25: 80-94, 1995.

6. Driscoll KE, Carter JM, Howard BW, Hassenbein D. Pepelko W, Bages R, Oberdorster G. Pulmonary inflammatory and mutagenic responses to subchronic inhalation of carbon black by rats. Toxicol Appl Pharmacol 136: 372-380, 1996.

7. Weiss SJ, Lobuglio AF. Phagocyte-generated oxygen metabolism and cellular injury. Lab /mesi 47: 5-18, 1982

8. Janssen YM, Matalon S, Mossman BT. Differential induction of c-fos, c-jun and apoptosis in lung epithelial cells exposed to ROS or RNS. Am J Physiol 273: L.789-L.796, 1997.

9. Janssen YM, Driscoll KE, Howard B, Quinlan TR. Treadwell M, Barchowski A, Mossman BT. Asbestos causes translocation of p65 protein and increases NF-kappa B DNA binding activity in rat lung epithelial and pleural mesothelial cells. Am J Pathol 151: 389-401, 1997.

10. Driscoll KE, Deyo LC. Carter JM, Howard BW, Hassenbein DG, Bertram TA. Effects of particle exposure and particle-elicited inflammatory cells on mutation in rat alveolar epithelial cells. Carcinogenesis 18: 423-430, 1997.

11. MeDonald RJ, Pan LC, St.George JA. Hyde DM, Ducore JM. Hydrogen peroxide induces DNA single strand breaks in respiratory epithelial cells. Inflammation 17: 715-722, 1993.

12. Dekhuijzen PN, Aben KK, Dekker I. Aarts L.P. Wielders PL. Van Herwaarden CL. Bast A. Increased exhalation of hydrogen peroxide in patients with stable and unstable chronic obstructive pulmonary disease Am J Respir Crit Care Med 15: 813-816, 1996.

13. Pinamonti S, Muzroli M, Chicca MC, Papi A, Ravenna F. Fabbri LM, Ciaccia A. Xanthine oxidase activity in bronchoalveolar lavage fluid from patients with chronic obstructive pulmonary disease. Free Radic Biol Med 21: 147 155, 1996.

14. Borm PJA, Driscoll KE. Particles, inflammation and respiratory tract carcinogenesis. Toxicol Left 110: 109-113, 1996.

15. Nehls P. Seiler F, Rehn B, Greferath R, Bruch J. Formation and persistence of 8-oxoguanine in rat lung cells as an important determinant for tumor formation following particle exposure. Environ Health Persp 105: 1291-1296, 1997.

16. Borm PJA, Knaapen AM, Schins RPF, Godschalk RWI. Van Schooten FJ. Neutrophils amplify the formation of DNA adducts by benzolalpyrene in lung target cells. Environ Health Persp 105: 1089-1093, 1997.

17. Floyd RA. The role of 8-hydroxyguanine in carcinogenesis. Carcinogenesis 11: 1447-1450, 1990.

18. Driscoll KE, Carter JM, Iype PT, Kumari HL, Crosby LL, Aardema MJ, Isfort RJ, Cody D, Chestnut MH, Burns JL, Le Boeuf RA. Establishment of immortalized alveolar type II cell lines from adult rat lungs. In vitro Cell Dev Biol 31 : 516 527, 1995.

19. Beyum A. Isolation of lymphocytes, granulocytes and macrophages. Scan J of Immunol 5: 9-15, 1976.

20. Mosmann T. Rapid colometric assay for cellular growth and survival: application to proliferation and cytotoxicity assays. J Immunol Weth 65: 516-527, 1983

21. Dong HY, Buard A, Renier A, I evy F, Saint-Ftienne L, Jaurand MC. Role of oxygen derivates in the toxicity and DNA damage produced by asbestos on pleural mesothelial cells in vitro. Carcinogenesis 15: 1251-1255, 1994.

22. Schins RPF, Schilderman PAEL. Borm PJA. Oxidative DNA-damage in peripheral blood lymphocytes of coal workers. Int Arch Occup Eimiron Health 67: 153-157, 1995

23. Floyd RA, Watson JJ, Harris J. West M, Wong PK. Formation of 8-hydroxydeoxyguanosine, hydroxyl free radical adduct of DNA in granulocytes exposed to the tumor promoter, tertadeconylphorbolacetate. Biochem Biophys Res Cimm 137; 841-846, 1986 .

24. Seiler F. Kirstein U. Fberle G, Hochleitner K. Rajewski FM. Quantification of specific DNA O-alkylation products in individual cells by monoclonal antibodies and digital imaging of intensified nuclear fluorescence. Carcinogenesis 9 : $1907-1913,1993$

25. Shigenaga MK. Ames BN. Assays for 8-hydroxy-2'deoxyguanosine: a biomarker for in vivo oxidative damage. Free Rivik Biol Mod 10; 211-216, 1991

26. Takeuchi I. Matsugo S, Morimoto K. Mutagenicity of oxidative DNA damage in chinese hamster V79 cells. Carcinogrencsis 18: 2051-2055, 1997

27. Bechman JS, Chen J. Ischiropoulos H. Crow JP. Oxidative chemistry of peroxynitrite. Weth Ensimol 233: 226-240. 1004.

28. Halliwell B, Aruoma OI. DNA damage by oxygen-derived species. Its mechanism and measurement in mammalian systems, FERS lent 281:9.19, 1901.

29. Shacter F. Becham EJ, Corey JM, Kohn KW. Potter M. Activated neutrophils induce prolonged DNA damage in neighboring cells. Carvinogencsis 9: 2207-2304, 1988

30. Kinnula VI. Chang 1. Fveritt J, Crapo JD. Oxidants and antiovidants in alveolar epithelial type II cells: in situ. freshly isolated. and cultured cells. Am I Phisio/ 262:1.69.1.77, 1992 
31. Holley JA, Janssen YMW, Mossman BT, Taatjes DJ. Increased Mn-SOD protein in type II epithelial cells of rat lungs after inhalation of crocidolite asbestos or cristobalite silica. Am J Path 141:475-485, 1992.

32. Sibille Y, Marchandise FX. Pulmonary immune cells in health and disease: Polymorphonuclear neutrophils. Eur Respir J6: $1529-1543,1993$.

33. Simon RH, DeHart PD, Todd RF. Neutrophil-induced injury of rat alveolar epithelial cells. $J$ Clin Imvest 78 : 1375 1386, 1986.

34. Kuchino Y, Mori F, Kasai H, Inoue H, Iwai S, Miura K, Ohtsuka E, Nishimura S. Misreading of DNA templates containing 8-hydroxy-deoxyguanosine at the modified base and at adjacent residues. Nature 327: 77, 1987. 


\title{
Chapter 6
}

\section{Mechanisms of neutrophil-induced DNA damage in respiratory tract epithelial cells}

\author{
Ad M Knaapen, Roel PF Schins, Dünya Polat, Andrea Becker, Paul JA Borm
}

Department of Fibre \& Particle Toxicology. Medical Institute of Environmental Hygiene. Auf 'm Hennekamp 50, 40225 Düsseldorf, Germany

\begin{abstract}
Reactive oxygen species (ROS) released by polymorphonuclear neutrophils have been suggested to play an important role in cancer development. Since the mechanisms underlying this effect in the respiratory tract are still unclear, we evaluated DNA damage induced by neutrophils in respiratory tract epithelial cells in vitro and in vivo. For in vitro studies, rat lung epithelial cells (RLE) were co-incubated with activated neutrophils, neutrophil-conditioned medium, or hydrogen peroxide. For in vivo studies, we considered the human nose as a target organ, comparing neutrophilic inflammation in the nasal lavage fluid with the oxidative DNA lesion 8-hydroxydeoxyguanosine (8-OHdG) in epithelial cells obtained by nasal brush. Our in vitro data show that human neutrophils are able to induce both $8-\mathrm{OHdG}$ and strand breaks in DNA from RLE cells. Our data also suggest that DNA damage induced by neutrophils is inhibited when neutrophil-derived $\mathrm{H}_{2} \mathrm{O}_{2}$ is consumed by myeloperoxidase. In contrast, in the nose no association between neutrophil numbers and 8-OHdG was found. Therefore, it remains unclear whether neutrophils pose a direct genotoxic risk for the respiratory tract epithelium during inflammation, and more in vivo studies are needed to elucidate the possible association between neutrophils and genotoxicity in the lung.
\end{abstract}

Based on: Molecular and Cellular Biochemistry 234/235: 143-151, 2002. 


\section{Introduction}

Inflammation has been recognised as an important factor in cancer development [1]. However, for the respiratory tract the mechanism underlying this carcinogenic response is still unclear. It is postulated that reactive oxygen species (ROS), derived from inflammatory neutrophils (PMN) play a key role in lung tumour formation in particle-exposed rats [2,3]. Upon activation, neutrophils and other phagocytes generate superoxide $\left(\mathrm{O}_{2}{ }^{\circ}\right)$ by the reduction of oxygen, a reaction catalysed by the enzyme NADPH-oxidase. During this 'respiratory burst' the action of additional neutrophilic enzymes, such as superoxide dismutase, myeloperoxidase and nitric oxide synthase will give rise to basically four oxidants: superoxide, hydrogen peroxide $\left(\mathrm{H}_{2} \mathrm{O}_{2}\right)$, nitric oxide $\left(\mathrm{NO}^{\circ}\right)$ and hypochlorous acid $(\mathrm{HOCl})$, which are originally manufactured for killing invading micro-organisms [4]. Studies performed by Weitzman and Weitberg in the early eighties showed that products of the respiratory burst of neutrophils can induce cytogenetic changes as well as malignant transformation in target cells. These findings clearly contribute to the hypothesis that inflammation and carcinogenesis are linked via ROS-induced damage to target cellular DNA $[5,6]$.

ROS are supposed to be involved in carcinogenesis by their capacity to induce genotoxic effects to cellular DNA [7]. Apart from testing single reactive oxygen or nitrogen species, another approach is to apply in vitro models in which target cells are co-incubated with neutrophils. Early work using these models demonstrated that neutrophils are able to induce sister chromatide exchanges in co-cultured target cells [5]. Shacter et al. [8] showed that neutrophils induce strand breaks in neighboring cells, and they suggested that hydrogen peroxide is the essential mediator of these effects. More specifically, hydroxyl radicals ( $\mathrm{OH}$ ), intracellularly produced either from $\mathrm{H}_{2} \mathrm{O}_{2}$ by Fenton chemistry or by decomposition of peroxynitrite $\left(\mathrm{ONOO}^{\circ}\right.$, a product of $\mathrm{O}_{2}{ }^{-}$and $\mathrm{NO}^{\circ}$ ), are thought to be the most likely ROS responsible for these neutrophil-mediated DNA damaging effects $[9,10]$. This is further confirmed by experiments performed in our laboratory, demonstrating that neutrophils cause induction of the $\mathrm{OH}$ specific DNA base lesion 8-hydroxydeoxyguanosine (8-OHdG) in alveolar type II cells in vitro [11]. These findings are also in line with observations in rat lungs, where increased levels of $8-\mathrm{OHdG}$ were found in alveolar cells during particle-elicited inflammation [12].

In rats, chronic exposure to poorly soluble particles can lead to tumour formation, and genetic alterations induced by neutrophil-derived oxidants as well as increased cell proliferation are thought to be key factors in this process [13]. However, recent studies on particle-exposed rats demonstrated that mutagenicity in lung epithelial cells was only observed after crystalline but not amorphous silica exposure, despite an equal high degree of inflammation ( $50 \%$ neutrophils in BAL), suggesting that neutrophilic inflammation alone was not enough to cause these genotoxic effects in lung epithelial cell DNA [14]. Therefore, it is still speculative whether neutrophils directly contribute to genotoxicity in lung epithelial cells in vivo, and whether this process might occur in humans [15]. It was the purpose of the present study to employ the human nose, as an easily accessible part of the respiratory tract to study the relation between neutrophils and DNA damage in respiratory tract epithelial cells in vivo. The in vivo data are linked to recent in vitro observations, to further elucidate the processes possibly involved in direct neutrophil-induced DNA damage in respiratory tract epithelial cells. 


\section{Materials and Methods}

\section{Chemicals}

Diaminobenzidine-tetrahydrochloride (DAB), Hanks' balanced salt solution (HBSS), Ethidium bromide, Ham's F12 and RPMI medium, HEPES buffer, Fetal calf serum (FCS), 3(4,5-dimethylthiazol-2-yl)-2,5-diphenyltetrazolium bromide (MTT), Phosphate buffered saline (PBS) and Trypsin/EDTA were all obtained from Sigma (St. Louis, MO). Hydrogen peroxide $\left(\mathrm{H}_{2} \mathrm{O}_{2}\right)$ was purchased from Fluka (Germany) and RNAse was obtained from Boehringer (Mannheim, Germany). Agarose, horseradish peroxidase (HRPO), guaiacol, sodium azide, and phorbol-12-myristate-13-acetate (PMA) were purchased from Sigma. All other chemicals were from Merck (Germany) and were of highest purity.

\section{Cell culture and co-incubation}

Rat lung epithelial cells (RLE), kindly provided by Dr. K. Driscoll, and were cultured in Ham's F12 medium, supplemented with $1 \%$ IM HEPES buffer, $1 \%$ penicillin/streptomycin solution (Sigma) and $5 \%$ heat inactivated FCS [16]. Cells were routinely grown in $75 \mathrm{~cm}^{2}$ cell culture flasks and passaged twice a week. Culture medium was refreshed every 2 days. Experiments were always performed between cell passages 40-55. Co-incubation experiments were performed as previously described [11]. RLE cells were either seeded in $175 \mathrm{~cm}^{2}$ flasks for 8-OHdG analysis (final volume $25 \mathrm{ml}, 8.75 \times 10^{5} \mathrm{PMN} / \mathrm{ml}$ ) or in 24-well plates for DNA strand breakage analysis (final volume $400 \mu \mathrm{l}, 5.5 \times 10^{5} \mathrm{PMN} / \mathrm{ml}$ ). The freshly isolated human peripheral blood neutrophils were added at a ratio of 1:1 to a confluent monolayer of RLE cells (considering that a confluent culture plate contains about $1.25 \times 10^{5}$ RLE cells per $\mathrm{cm}^{2}$ ). Cells were co-incubated for 2 hours in HBSS. Neutrophils were activated with PMA (100 $\mathrm{ng} / \mathrm{ml}$ ) as a direct activator of protein kinase $\mathrm{C}$ to elicit a respiratory burst. After incubation, neutrophils were washed off using PBS $\left(4^{\circ} \mathrm{C}\right)$, and RLE cells were harvested by trypsin for further analysis. Microscopic differentiation of cytospin preparations from harvested RLE cells proved that washing off procedures were efficient In some experiments, RLE cells were exposed to cell-free supernatants obtained from PMA-activated neutrophils (= neutrophilconditioned medium). Therefore, $2.2 \times 10^{5}$ neutrophils were seeded in $400 \mu \mathrm{l}$ HBSS and activated by PMA. This represents a same neutrophil concentration as used in the coincubations performed in 24 well plates for DNA strand break analysis. After $1 \mathrm{~h}$, the supernatants were taken and used for incubation with the RLE cells ( $2 \mathrm{~h}$ ). Hydrogen peroxide $(0-100 \mu \mathrm{M})$ was used as a positive control for both $8-\mathrm{OHdG}$ and strand break formation.

\section{MTT-cytotoxicity assay}

Cytotoxicity of oxidants was tested using the MTT colorimetric assay according to Mosmann et al. [17], and was described previously [18]. Briefly, oxidants were dissolved in HBSS, added to the cells (seeded in 96-well plates) and incubated for 2 hours $\left(37^{\circ} \mathrm{C}, 5 \% \mathrm{CO}_{2}\right)$. Then, $25 \mu \mathrm{l}$ of 3-(4,5-dimethylthiazol-2-yl)-2,5diphenyl-tetrazolium bromide (MTT, $2 \mathrm{mg} / \mathrm{ml}$ ), dissolved in PBS was added, and incubated for another $2 \mathrm{~h}$. Finally, HBSS-solutions were removed and formazan chrystals were dissolved in DMSO and absorption was measured using a microplate reader (Labsystems) at $540 \mathrm{~nm}$. Toxicity was calculated as \% of control.

\section{Measurement of hydrogen peroxide and myeloperoxidase}

Hydrogen peroxide was measured according to the method described by Pick and Keisari [19]. For all measurements neutrophils were used at the same concentrations as used for the co-incubations $\left(5.5 \times 10^{5}\right.$ cells $\left./ \mathrm{ml}\right)$. Neutrophils were suspended in HBSS containing $8.5 \mathrm{U} / \mathrm{ml}$ horseradish peroxidase and $0.28 \mathrm{mM}$ phenol red, and plated in 24-well plates. Cells were 
activated by PMA $(100 \mathrm{ng} / \mathrm{ml})$ with or without sodium azide $(50 \mu \mathrm{M})$. After incubation $(2 \mathrm{~h})$, cells were centrifuged, and to $500 \mu \mathrm{l}$ of the supernatant $5 \mu \mathrm{l}$ of $1 \mathrm{M} \mathrm{NaOH}$ was added. Absorption was measured at $610 \mathrm{~nm}$ using a spectrophotometer (Beckman) and final concentrations were calculated from a standard curve of $\mathrm{H}_{2} \mathrm{O}_{2}$. In other experiments, supernatants from neutrophils activated with PMA were used to determine accumulation of hydrogen peroxide. Therefore, neutrophils were incubated for $2 \mathrm{~h}$ in the presence of PMA or azide. Supernatants were subsequently used to measure hydrogen peroxide spectrophotometrically according to the method of Gallati and Pracht [20]. Absorption was measured at $450 \mathrm{~nm}$ using a microplate reader (Multiskan, Labsystems). In the same supernatants, accumulated myeloperoxidase (MPO) activity was assayed according to Klebanoff et al. [21]. Therefore, $50 \mu$ l was mixed with $450 \mu \mathrm{l}$ MPO assay solution, containing $107.6 \mathrm{ml} \mathrm{H} 2 \mathrm{O}, 12 \mathrm{ml}$ sodium phosphate buffer $(0.1 \mathrm{M}), 0.192 \mathrm{ml}$ guaiacol, $0.4 \mathrm{ml} \mathrm{H} \mathrm{O}_{2}(0,1$ $\mathrm{M})$. The generation of tetra-guaiacol was measured spectrophotometrically (Beckman) at 470 $\mathrm{nm}$ and the change of optical density per minute was calculated from the initial rate. MPO activity was expressed as $\mathrm{mU} / \mathrm{ml}$.

\section{DNA strand break analysis (comet assav)}

DNA strand break formation in RLE cells was determined by the comet-assay [22,23], as follows. Fully frosted slides were covered with a layer of $0.65 \%$ agarose using a coverslip and stored overnight at $4^{\circ} \mathrm{C}$. RLE cells were harvested from the 24 well plates using trypsin and were then suspended in HBSS. Cytotoxicity in RLE cells caused by exposure procedures and subsequent cell processing was evaluated using Trypan Blue dye exclusion. Subsequently, 25 $\mu \mathrm{l}$ of the cell suspension $\left(2 \times 10^{6}\right.$ cells $\left./ \mathrm{ml}\right)$ was mixed with $75 \mu \mathrm{l} 0.5 \%$ low melting point agarose. This mixture was then added to the slides, on top of the first agarose layer using a coverglass. Slides were stored 45 minutes at $4^{\circ} \mathrm{C}$ to allow solidification, and covered with another layer of low melting point agarose $(100 \mu \mathrm{l})$. Following solidification for at least 45 minutes at $4^{\circ} \mathrm{C}$, slides were immersed in lysis buffer $(2.5 \mathrm{M} \mathrm{NaCl}, 100 \mathrm{mM}$ EDTA, $10 \mathrm{mM}$ Tris-base, 1\% Sodium Lauryl sarcosinate, $\mathrm{pH} 10 ; 10 \%$ DMSO and $1 \%$ Triton X-100 added just before use) and stored overnight at $4^{\circ} \mathrm{C}$. The following day, slides were rinsed with distilled water and placed in an electrophoresis tank filled with ice-cold electrophoresis buffer $(300 \mathrm{mM} \mathrm{NaOH}, 1 \mathrm{mM}$ EDTA, pH 13) for 30 minutes. Electrophoresis was conducted at 300 $\mathrm{mA}$ and $25 \mathrm{~V}$ for 15 minutes. Slides were then neutralised $3 \times 10 \mathrm{~min}$ using neutralisation buffer (0.4 M Tris, pH 7.5). All steps described were performed in the dark to prevent additional DNA damage. Slides were stained with ethidium bromide $\left(20 \mu \mathrm{g} / \mathrm{ml}\right.$ in $\left.\mathrm{H}_{2} \mathrm{O}\right)$ and comet appearances were analysed using an Olympus BX60 fluorescence microscope at 1000x magnification. Samples were tested in dulplicate within each experiment. On every single slide, 50 cells were analysed randomly, and classified into one out of five categories according to tail length $(0,1,2,3,4$, in which $0=$ no tail $)$. For final analysis a 'comet-score' of each individual slide was calculated: Comet Score $=$ sum(class 1 cells + class 2 cells $\times 2+$ class 3 cells $\times 3$ + class 4 cells $\times 4$ ). Using this formula a maximally damaged sample obtains a comet score of 200. Data were expressed as mean ( \pm sd) from 3 individual experiments.

\section{Nasal lavage and nasal brush}

To extend our in vitro observations to an in vivo situation, we studied the association between nasal inflammation (total cell count, neutrophil numbers) and the induction of $8-\mathrm{OHdG}$ in nasal epithelial cells from 80 children selected from a larger cohort sampled in Nordrheinland-Westfalen (Germany). Only children without hay fever or specific allergy, based on questionnaire and skin-prick test to 5 common allergens were included for this study. Nasal lavage and processing of lavage fluid was described by Keman et al. [24], except that $5 \mathrm{ml}$ of fluid was instilled in a single nostril. Inflammatory effects were assessed by 
counting total number of cells and the proportion of neutrophils, eosinophils, lymphocytes and monocytes, and by measuring interleukin- 8 (IL-8) concentration in nasal lavage fluid, using ELISA [24]. To obtain nasal epithelial cells, the ventral surface of the inferior nasal turbinates was brushed using an interdental brush (Deflogrip). The brush containing the epithelial cells was immediately immersed in RPMI medium $\left(4^{\circ} \mathrm{C}\right)$, and cells were removed from the brush by shaking followed by vortexing. Cells were centrifuged $(600 \mathrm{~g}, 5 \mathrm{~min}$.), resuspended in $300 \mu \mathrm{l}$ HBSS of which $200 \mu \mathrm{l}$ was further diluted in $600 \mu \mathrm{l}$ Carbowax-buffer $(0.8 \%$ polyethyleneglycol in $70 \%$ ethanol). From this suspension cytospin preparations were made (Shandon, $800 \mathrm{rpm}, 5 \mathrm{~min}$ ). Slides were dried on air ( $30 \mathrm{~min})$, fixed in $100 \%$ aceton ($20^{\circ} \mathrm{C}, 5 \mathrm{~min}$ ), and stored at $-80^{\circ} \mathrm{C}$ until analysis for $8-\mathrm{OHdG}$. For final analysis 80 non-allergic children were selected based on total cell numbers present in the nasal lavage and grouped into 4 quartiles. Levels of 8-OHdG in subjects from the upper $(n=30)$, the two middle (each $\mathrm{n}=10)$, and the lower $(\mathrm{n}=30)$ quartiles were then analysed as described below.

\section{8-Hydroxydeoxyguanosine analysis}

Oxidative DNA damage in RLE cells after exposure to either oxidants or neutrophils was assessed by measuring $8-\mathrm{OHdG}$. DNA from RLE cells was isolated and processed as described elsewhere [11], and 8-OHdG was then measured by high performance liquid chromatography with electrochemical detection (HPLC-ECD) as described by Schins et al. [25]. Similar analysis in nasal epithelial cells was not possible due to the low amount of sampling material. Therefore, we applied a semi-quantitative immunostaining for 8-OHdG described by Knaapen et al. [26], with minor modifications. 8-OHdG was detected using a monoclonal antibody (N45.1) [27]. Subsequently, staining was developed using an ABC kit (Vectastain, Vector Laboratories, USA). Slides were mounted with Depex (Boehringer, Germany), and staining of $8-\mathrm{OHdG}$ was then visualised and quantified using a microscopecoupled software analysis system (Soft Imaging System, Germany). Staining contrast distribution of 100 epithelial cells per slide was measured and used to determine 8-OHdG levels.

\section{Results and Discussion}

\section{Effect of hydrogen peroxide on epithelial cell viability and DNA damage}

Since neutrophil-induced DNA damage is thought to be mediated by the release of hydrogen peroxide [8], we evaluated both cytotoxicity and DNA damage induced by this compound in lung epithelial target cells. When RLE cells where exposed to increasing concentrations of hydrogen peroxide a clear dose dependent loss of cell viability was observed. The concentration necessary to induce a $50 \%$ decrease in viability $\left(\mathrm{LC}_{50}\right)$ was $175 \mu \mathrm{M}$. Already at non-toxic concentrations of $10 \mu \mathrm{M} \mathrm{H}_{2} \mathrm{O}_{2}, 8-\mathrm{OHdG}$ levels and DNA strand breaks were increased by respectively $150 \%$ and $130 \%$ compared to controls (Data not shown). These data indicate that in RLE cells DNA damage is detectable at low, non-cytotoxic levels of hydrogen peroxide. Therefore, these cells can be considered as a sensitive target to investigate genotoxic effects of neutrophil-derived oxidants.

\section{Direct genotoxic effects of neutrophils: use of an in vitro co-incubation model}

Recently, we developed a co-incubation model to study the mechanism of the genotoxic effects of neutrophils (PMN) on lung epithelial cells. In this model, we focussed on rat alveolar type II epithelial cells (RLE), because it is the cell type from which tumours are thought to be derived as a result of particle-induced neutrophilic inflammation in rat lungs [28]. When RLE cells were co-incubated with PMA-activated neutrophils, an increase in the 
'OH specific DNA adduct 8-OHdG was observed in the RLE cells [11]. Here, we showed that DNA strand breaks were also induced (Figure 1).

$\mathbf{A}$

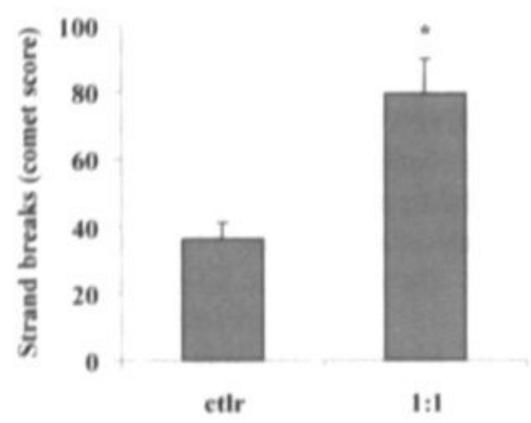

B

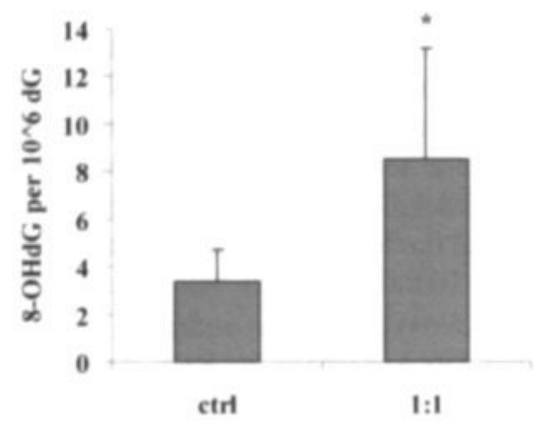

Figure 1. DNA damage in RI.E cells induced by neutrophils in vitro. RL.E cells were exposed (2h) to PMA-activated (100 ng/ml) neutrophils at a I:I ratio. A) DNA strand breaks in RI.E cells were assessed by single cell gel electrophoresis (comet assay) and are expressed as Comet Score $(n-3$, mean + sd). B) 8-OHdG was measured using high pressure liquid chromatography with electro-chemical detection (HPLC-ECD) and is expressed as number of 8-OHdG residues per $10^{6}$ dG $(\mathrm{n}=6$, mean 1 sd). * p 0.05 vs. control (ctrl) (T-test). For both assays PMA alone did not have an effect (data not shown).

Various studies indicated that $\mathrm{H}_{2} \mathrm{O}_{2}$ plays an important role in PMN-induced DNA strand breakage and DNA base modifications (8-10). Common opinion is that $\mathrm{H}_{2} \mathrm{O}_{2}$ generated by neutrophils serves as a latent form of ${ }^{\circ} \mathrm{OH}$, which attacks cellular DNA $(9,10)$. Hydrogen peroxide is relatively stable and is shown to cross cellular membranes. Moreover, it can penetrate the nucleus where ${ }^{\circ} \mathrm{OH}$ can be generated in the vicinity of a DNA molecule via the Fenton reaction [29]. In our co-incubation model, as used to detect DNA strand breaks, neutrophils maximally produced $\mathrm{H}_{2} \mathrm{O}_{2}$ reaching concentrations of $29.5 \pm 6.9 \mu \mathrm{M}$ after 2 hours (Table IA). At this ratio strand breaks (comet-score) in target cells increased about 2 -fold compared to unexposed cells (Figure 1). In contrast, when RLE cells were exposed to $25 \mu \mathrm{M}$ hydrogen peroxide solution, DNA damage was increased 3.5 -fold, without causing cytotoxicity (data not shown). Although it is difficult to really compare effects induced by a single bolus of $\mathrm{H}_{2} \mathrm{O}_{2}$ with effects as induced by a flux of $\mathrm{H}_{2} \mathrm{O}_{2}(\mathrm{PMN})$, a possible explanation for the observed differences might be the fact that in neutrophils part of the hydrogen peroxide is consumed by the enzyme myeloperoxidase (MPO). Therefore, not all of the $\mathrm{H}_{2} \mathrm{O}_{2}$ as measured during the incubation (Table 1A), may be available to interact with the target cells. Indeed MPO, which is a haeme peroxidase present in the azurophilic granules of neutrophils, normally uses up to $70 \%$ of the neutrophil-derived $\mathrm{H}_{2} \mathrm{O}_{2}$ to generate the strong oxidant $\mathrm{HOCl}[30]$. This is partly illustrated by the data shown in Table 1A: addition of the MPO inhibitor sodium azide increased the concentration of $\mathrm{PMN}$-released $\mathrm{H}_{2} \mathrm{O}_{2}$. The effect of MPO is further demonstrated by the data shown in part $\mathrm{B}$ of table 1 : accumulation of $\mathrm{H}_{2} \mathrm{O}_{2}$ in neutrophil-conditioned medium was only observed in the presence of the MPO inhibitor sodium azide. As a consequence, cell-free conditioned medium obtained from neutrophils, was only able to induce DNA strand breaks in RLE cells when it was derived from neutrophils that were activated in the presence of sodium azide (Figure 2). This effect is not caused by a possible inhibition of cellular catalase, since azide at this concentration $(50 \mu \mathrm{M})$ 
did not increase $\mathrm{H}_{2} \mathrm{O}_{2}$-induced DNA strand breaks in RLE cells (data not shown). Schraufstätter et al [9] demonstrated that the product of the MPO-catalysed reaction of $\mathrm{H}_{2} \mathrm{O}_{2}$ and $\mathrm{Cl}, \mathrm{HOCl}$, was not able to induce DNA damage in target cells, whereas others only found HOCl-mediated DNA strand breakage at non-physiological, cytotoxic doses [31]. Moreover, it should be emphasised that $\mathrm{HOCl}$ is very reactive and is able to react with any cellular target before it reaches the nucleus [32]. Such a mechanism implies that the activity of MPO actually protects lung cells from neutrophil-elicited DNA damage by conversion of the stable and genotoxic $\mathrm{H}_{2} \mathrm{O}_{2}$ into the more cytotoxic $\mathrm{HOCl}$ [9]. Furthermore, our data indicate that induction of DNA damage by neutrophils can only occur when neutrophil-derived $\mathrm{H}_{2} \mathrm{O}_{2}$ is produced in direct proximity of the target cell where it can be captured, preventing a premature reaction with MPO or other extracellular components, such as catalase or glutathione.

Table I Release of hydrogen peroxide and myeloperoxidase by activated neutrophils.

\begin{tabular}{l|c|cc}
\hline & During incubation & \multicolumn{2}{c}{ Neutrophil-conditioned medium $^{\mathrm{N}}$} \\
\hline & $\mathrm{H}_{2} \mathrm{O}_{2}(\mu \mathrm{M})$ & $\mathrm{H}_{2} \mathrm{O}_{2}(\mu \mathrm{M})$ & $\mathrm{MPO}(\mathrm{mU} / \mathrm{ml})$ \\
Neutrophils & $4.0(2.9)$ & 0 & 0 \\
Neutrophils+PMA & $29.5(6.9)^{*}$ & $0.1(0.1)$ & $20.8(1.3)^{n / 1}$ \\
Neutrophils+PMA+NaN & $41.5(2.8)^{* *}$ & $19.7(0.2)^{n}$ & $0.6(0.1)$ \\
& & & \\
\hline
\end{tabular}

\footnotetext{
${ }^{A} \mathrm{H}_{2} \mathrm{O}_{2}$ was measured according to Pick et al. [19]: Neutrophils $\left(5.5 \times 10^{5}\right.$ cells/ml) were incubated in the presence of an excess of horseradish peroxidase, what at least partly avoids loss of $\mathrm{H}_{2} \mathrm{O}_{2}$ due to activity of neutrophil-derived peroxidases such as myeloperoxidase (MPO). Cells were activated with PMA $(100 \mathrm{ng} / \mathrm{ml})$. Data are expressed as mean \pm sd. "p 0.05 vs. neutrophils, "*p<0.01 vs neutrophils (T-test).

${ }^{B}$ Neutrophils $\left(5.5 \times 10^{5}\right.$ cells $\left./ \mathrm{ml}\right)$ were incubated for $2 \mathrm{~h}$ in HBSS. After incubation, cells were centrifuged and supernatants were used for detection of both accumulated MPO and hydrogen peroxide. Sodium azide $\mathrm{NaN}_{3}(50 \mu \mathrm{M})$ was used to inhibit MPO. $\mathrm{H}_{2} \mathrm{O}_{2}$ and MPO levels are expressed as mean \pm sd. "p<0.01 vs. neutrophils, and neutrophils + PMA. "p<0.01 vs. neutrophils (T-test).
}

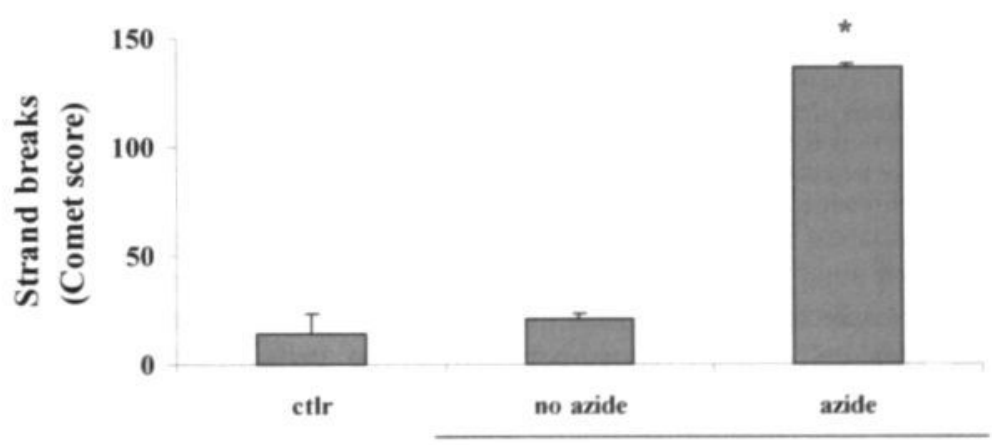

Neutrophil-conditioned medium

Figure 2. DNA-strand breakage in RLE cells exposed to neutrophil-conditioned medium. Neutrophils $\left(2.2 \times 10^{5}\right.$ cells in 400 $\mu$ I HBSS) were incubated for $\mathrm{lh}$. and activated with PMA $(100 \mathrm{ng} / \mathrm{ml})$ with or without sodium azide $\left(\mathrm{NaN}_{3}, 50 \mu \mathrm{M}\right)$. The cell-free supernatants from these neutrophils (= neutrophil-conditioned medium) were subsequently transferred to RLE cells grown in 24 well plates and incubated for another $2 \mathrm{~h}$. Strand breaks in the RLE cells were then assessed using the comet assay, and are expressed as comet score. Azide and PMA alone did not have an effect on DNA damage. (ctrl = HBSS only). *p<0.01 vs. control (ctrl) or without azide (T-test). 
Neutrophil-induced oxidative DNA damage in respiratory tract epithelial cells: the nose Although our in vitro experiments indicate that oxidants released by activated neutrophils are able to induce (oxidative) DNA damage in epithelial lung cells, only few data have described this association for the lung epithelium in vivo. In rats, levels of $8-\mathrm{OHdG}$ or mutations in the HPRT gene, both observed in lung epithelial cells after particle exposure, were positively correlated with the percentage of neutrophils present in the BAL fluid [12,3]. For humans however, it is even more complicated to study whether neutrophils directly cause DNA damage in lung epithelial cells, merely since this necessitates invasive techniques. However, in earlier studies, we and others showed that the nose is an easy accessible part of the respiratory tract and a valid model to investigate inflammatory and genotoxic effects caused by exposure to environmental air pollutants [33,34]. Moreover, Graham et al. showed that neutrophil influx in the nose can be suggested as a good predictor of the situation in the lower lung [35]. Therefore, in an attempt to elucidate the possible involvement of neutrophils in the induction of DNA damage in respiratory tract epithelial cells in a human situation, we analysed both neutrophil numbers and levels of oxidative DNA damage in the nose from 80 non-allergic children. Nasal lavage was used to obtain information about the inflammatory status of the nose (total and differential cell count, neutrophil numbers, IL-8 concentration). Furthermore, from the same subjects, nasal epithelial cells were obtained by a nasal brush to determine 8-OHdG using immunohistochemistry (Figure 3).

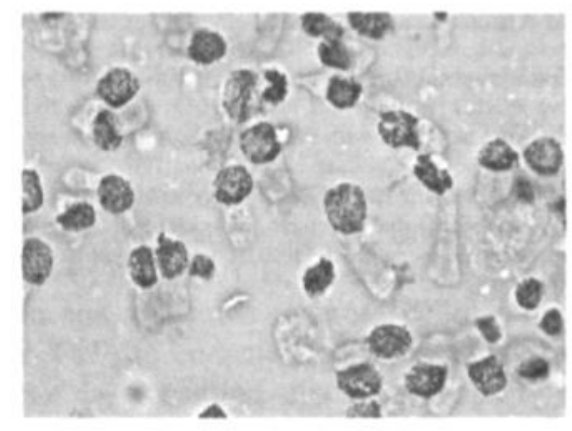

Figure 3. Representative picture of 8-OHdG staining in nasal epithelial cells. 8-OHdG was detected using a specific antibody as described in the methods section. Staining contrast distribution of 100 epithelial cells per slide was measured and used to calculate a score weighed for the intensity of the staining. Only cells exhibiting a clear epithelial morphology, as shown in the picture, were used for quantification. Picture was taken at 1000x magnification.

Subjects were selected and grouped into 4 quartiles based on total cell number in nasal lavage (Table 2). Total cell number ranged between $5.8 \times 10^{3}$ cells $/ \mathrm{ml}$ in the lowest quartile to approximately $5 \times 10^{5}$ cells $/ \mathrm{ml}$ in the upper quartile. Interestingly, the neutrophil numbers were closely related to the concentration of interleukin-8 (IL-8) in nasal lavage fluid (Table 2), supporting the possible role of IL-8 as a neutrophil chemotactic factor in the nose [36,37]. Furthermore, Steerenberg et al. $[37,38]$ showed that neutrophil numbers correlated with the myeloperoxidase concentration in the nasal lavage, indicating that neutrophils present in the nose are activated, a process in which oxidant generation is accompanied by MPO release [30]. As shown in table 2, approximately $80 \%$ of the total cells were neutrophils, and no statistical difference in percentage was observed between the 4 quartiles. Since this approach as such mimics a dose-response for neutrophil-induced effects, we hypothesised that a higher neutrophil count would be accompanied by an increased level of oxidative DNA damage. 
However, as illustrated in figure 4 , no relation was found between total neutrophil numbers present in the lavage and the level of $8-\mathrm{OHdG}$ in the epithelial cells. This finding seems to be in conflict with the general consensus on the link between neutrophils and genotoxicity as observed in rat lung target cells cf. Greim et al. [15]. There are several possible explanations for this discrepancy. First, in the nose, the sampling site of the neutrophils might be slightly different from that of the target cells. The sampled neutrophils might therefore not have been in close contact with the sampled epithelial target cells. This adhesion is thought to be a crucial factor not only in neutrophil-induced cytotoxicity [39], but also in genotoxicity, as indicated from our present in vitro data: Whereas PMN can induce DNA damage in coincubated epithelial cells, this effect was absent when epithelial cells were incubated with neutrophil-conditioned medium. This observation could at least partly be explained by the consumption of the genotoxic $\mathrm{H}_{2} \mathrm{O}_{2}$ by MPO. As myeloperoxidase is present in nasal lavage fluid [37,38], this process could also occur in the nose, suggesting that diffusion of neutrophil-derived hydrogen peroxide to epithelial cells is prevented. Secondly, apart from possible neutrophil-derived oxidants, the nasal epithelium is directly exposed to oxidant gasses (e.g. ozone, $\mathrm{NO}_{\mathrm{x}}$ ) and other pollutants present in ambient air (e.g. particulate matter). These factors can generate oxidants in the human nasal compartment possibly leading to direct, neutrophil-independent oxidative processes such as aromatic hydroxylation or epithelial DNA damage $[40,34]$.

Table 2. Characteristics of non-allergic children selected for comparison of nasal inflammation and DNA damage. Data are mean and standard error of the mean.

\begin{tabular}{lcccc}
\hline $\begin{array}{l}\text { Quartiles (total cells in } \\
\text { nasal lavage) }\end{array}$ & $<25^{\text {th }}$ percentile & $\begin{array}{c}25-50^{\text {th }} \\
\text { percentile }\end{array}$ & $\begin{array}{c}50-75^{\text {th }} \\
\text { percentile }\end{array}$ & $\begin{array}{c}>75^{\text {th }} \\
\text { percentile }\end{array}$ \\
\hline $\begin{array}{l}\text { Number subjects } \\
\text { Age (yrs) }\end{array}$ & 30 & 10 & 10 & 30 \\
Total cells $\times 10^{3 *}$ & $6.4 \pm 0.4$ & $6.4 \pm 0.3$ & $6.4 \pm 0.5$ & $6.4 \pm 0.3$ \\
Neutrophils (\%) & $5.77 \pm 0.53$ & $21.87 \pm 2.46$ & $62.85 \pm 8.12^{\prime \prime}$ & $496.9 \pm 97.2^{\prime \prime}$ \\
IL-8 (pg/ml)* & $79.3 \pm 3.3$ & $89.4 \pm 1.7$ & $75.7 \pm 9.1^{*}$ & $77.0 \pm 1.7$ \\
& $685 \pm 164$ & $838 \pm 177$ & $1,408 \pm 291^{\prime \prime}$ & $1,641 \pm 216^{\prime \prime}$
\end{tabular}

\footnotetext{
- Statistically different between groups, ANOVA $(P<0.05)$.

'Statistically different from $25^{\text {th }}$ and $25^{\text {th }}-50^{\text {th }}$ percentile, ANOVA, LSD posthoc test $(P<0.01)$.
}

\section{Conclusions}

One of the main characteristics of ROS is their ability to induce structural changes in DNA [7]. To investigate neutrophil-induced genotoxicity many studies have focussed on the direct effects of single reactive oxygen species on DNA damage in target cells. However, to evaluate the genotoxic hazard of neutrophil-derived oxidants, models are needed that investigate the neutrophil-derived products as an entirety and not merely as single factors. Using such an in vitro co-incubation model, we demonstrated that neutrophils have the capacity to induce DNA damage in lung epithelial cells. Moreover, we showed that DNA damage by neutrophils can only occur when neutrophil-derived $\mathrm{H}_{2} \mathrm{O}_{2}$ is produced in direct proximity of the target cell, preventing a premature reaction with MPO or other neutrophil derived components. In contrast, our in vivo studies on the human nasal compartment could not demonstrate a link between neutrophils and DNA damage in nasal epithelium. Although this lack of correlation can partly be explained by our in vitro observations, it remains unclear whether neutrophils are directly genotoxic towards human lung epithelium in vivo, and more 
studies are needed to demonstrate the significance and to elucidate the role of neutrophils in the induction of DNA damage in epithelial cells of the human respiratory tract.

\section{Acknowledgements}

Dr. Kevin Driscoll is acknowledged for providing the RLE cells. We thank Astrid Winzer for her technical assistance. This study is partly supported by DFG project BO-1657, and biological samples were obtained in the course of a health effect screening program in Nordrhein-Westfalen, supported by the Ministry of Environment and Local Planning (MURL). We acknowledge the participation of all study-subjects, the Landesumweltamt in Essen (Germany), and Georg Eberwein for his coordination of the epidemiological study.

$\mathbf{A}$

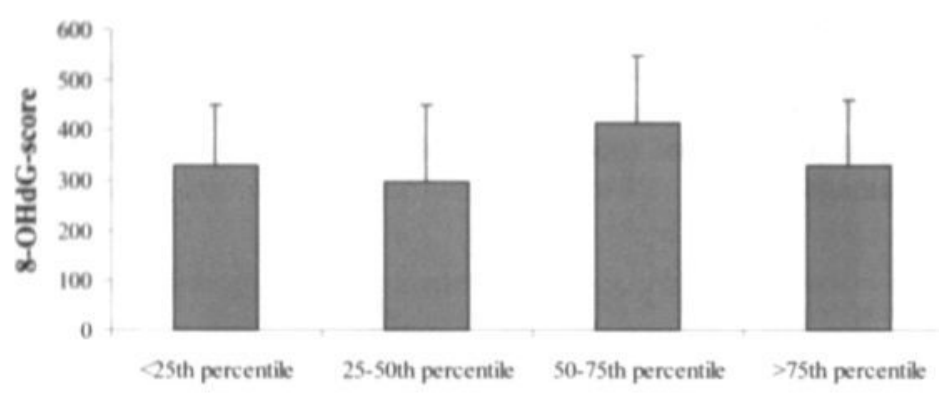

Quartiles based on total cell number

B

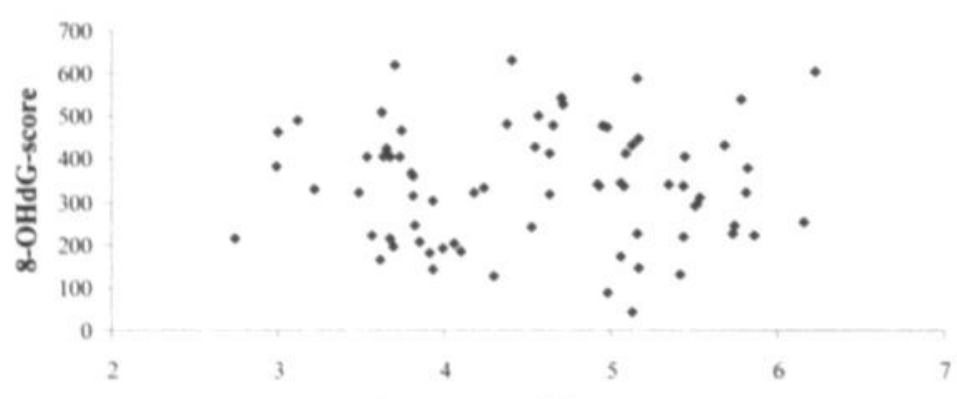

Log neutrophil number

Figure 4. Oxidative DNA damage in nasal epithelial cells from non-allergic children. Levels of 8-hydroxydeoxyguanosine (8-OHdG) were analysed using a specific immunostaining and are expressed as a score weighed for the intensity of the staining (8-OHdG-score). A) 8-OHdG-score in nasal epithelial cells from subjects grouped into 4 quartiles based on nasal inflammation (total cell number in nasal lavage). B) Relation between total neutrophil numbers and 8-OHdG. 


\section{References}

1. Weitzman SA, Gordon LI. Inflammation and cancer: Role of phagocyte-generated oxidants in carcinogenesis. Blood 76: 655-663, 1990.

2. Dungworth DL, Mohr U, Heinrich U, Emst H, Kittel B. Pathologic effects of inhaled particles in rat lungs: associations between inflammatory and neoplastic processes. In: Mohr U. (ed). Taxic and carcinogenic effects of solid particles in the respiratory tract. IL.SI press, Washington, 1994, pp 75-98.

3. Driscoll KE, Deyo LC, Carter JM, Howard BW, Hassenbein DG, Bertram TA. Effects of particle exposure and particle-elicited inflammatory cells on mutation in rat alveolar epithelial cells. Carcinogenesis 18: 423-430, 1997.

4. Babior BM. Phagocytes and oxidative stress. Am J Med 109: 33-44, 2000.

5. Weitberg AB, Weitzman SA, Destrempes M., Latt SA, Stossel TP. Stimulated human phagocytes produce cytogenetic changes in cultured mammalian cells. New Eng J Med 308: 26-29, 1983.

6. Weitzman SA, Weitberg AB, Clark EP, Stossel TP. Phagocytes as carcinogens: malignant transformation produced by human neutrophils. Science 227: 1231-1233, 1984.

7. Wiseman H. Halliwell B. Damage to DNA by reactive oxygen and nitrogen species: role in inflammatory disease and progression to cancer. Biochem J 313: 17-29, 1996.

8. Shacter E, Beecham EJ, Covey JM, Kohn KW, Potter M. Activated neutrophils induce prolonged DNA damage in neighboring cells. Carcinogenesis 9: 2297-2304, 1988.

9. Schraufstătter I, Hyslop PA, Jackson JH, Cochrane CG. Oxidant-induced DNA damage of target cells. J Clin Imvest 82: 1040-1050, 1988

10. Dizdaroglu M, Olinski R, Doroshow JH, Akman SA. Modification of DNA bases in chromatin of intact target human cells by activated human polymorphonuclear leukocytes. Cancer Res 53: 1296-1272, 1993.

11. Knaapen AM, Seiler F, Schilderman PAEL. Nehls P, Bruch J, Schins RPF, Borm PJA. Neutrophils cause oxidative DNA damage in alveolar epithelial cells. Free Rad Biol Med 27: 234-240, 1999

12. Nehls P. Seiler F. Rehn B, Greferath R. Bruch J. Formation and persistence of 8-oxoguanine in rat lung cells as an important determinant for tumor formation following particle exposure. Environ Health Persp I05 (suppl 5): 1291. 1296, 1997.

13. Driscoll KE. Role of inflammation in the development of rat lung tumors in response to chronic particle exposure. Inhal Toxicol 8(suppl): 139-153, 1996.

14. Johnston CJ, Driscoll KE, Finkelstein JN, Baggs R, O'Reilly MA, Carter J, Gelein R, Oberdörster G. Pulmonary chemokine and mutagenic responses in rats after subchronic inhalation of amorphous and crystalline silica. Toxicol $S_{c /}$ 56: 405-413, 2000.

15. Greim H, Borm PJA, Schins RPF, Donaldson K, Driscoll KE, Hartwig A, Kuempel E, Oberdörster G, Speit G. Toxicity of fibers and particles. Report of the workshop held in Munich, Germany, 26-27th October 2000. Inhal Toxicol 13: 101-119, 2001.

16. Driscoll KE, Carter JM, Iype PT, Kumari HL, Crosby LL, Aardema MJ, Isfort RJ, Cody D, Chestnut MH, Burns JL, Le Boeuf RA Establishment of immortalized alveolar type II cell lines from adult rat lungs. In Vitro Cell Dev Biol 31: 516 $527,1995$.

17. Mosmann T. Rapid colorimetric assay for cellular growth and survival: application to proliferation and cytotoxicity assays. J Immunol Meth 65: 517-527, 1983.

18. Borm PJA, Knaapen AM, Schins RPF, Godschalk RWL, Van Schooten FJ. Neutrophils amplify the formation of DNAadducts by benzo|a|pyrene in lung target cells. Environ Health Perspect 105 (suppl 5): 1089-1093, 1997

19. Pick E. Keisari YA. simple colorimetric method for the measurement of hydrogen peroxide produced by cells in culture. J Immunol Meth 38: 161-170, 1980.

20. Gallati H, Pracht I. Horseradish peroxidase: kinetic studies and optimization of peroxidase activity determination using substrates $\mathrm{H}_{2} \mathrm{O}_{2}$ and 3,3',5,5'-tetramethy lbenzidine. J Clin Chem Clin Biochem 23: 453-460, 1985.

21. Klebanoff SJ, Waltersdorph AM, Rosen H. Antimicrobial activity of myeloperoxidase. Meth Enzymol 105: 399-403. 1984.

22. Singh NP, McCoy MT, Tice RR, Schneider ELA. simple technique for quantitation of low levels of DNA damage in individual cells. Exp Cell Res 175: 184-191, 1988.

23. Olive PI, Banath JP. Durand RE. Heterogeneity in radiation-induced DNA damage and repair in tumor and normal cells measured using the "comet" assay. Radiat Res 122: 86-94, 1990

24. Keman S, Jetten M, Douwes J. Borm PJA. Longitudinal changes of inflammatory markers in nasal lavage of cotton workers. Int Arch Occup Environ Health 71: 131-137, 1998.

25. Schins RPF, Schilderman PAEL. Borm PJA. Oxidative DNA damage in peripheral blood lymphocytes of coal workers. Int Arch Occup Environ Health 67: 153-157, 1995.

26. Knaapen AM, Schins RPF, Steinfartz Y. Höhr D. Dunemann L., Borm PJA. Ambient particulate matter induces oxidative DNA damage in lung epithelial cells. Inhal Toxicol 12 (suppl 3): 125-132, 2000.

27. Toyokuni S. Tanaka T, Hattori Y, Nishiyama Y, Yoshida A, Uchida K. Hiai H. Ochi H, Osawa T. Quantitative immunohistochemical determination of 8-hydroxy-2'-deoxyguanosine by a monoclonal antibody N45.I: Its application to ferric nitrolotriacetate-induced renal carcinogenesis model. Lab Imvest 76: 365-374, 1997.

28. Nikula KJ, Snipes MB, Barr EB, Griffith WC. Henderson RF, Mauderly J. Comparative pulmonary toxicities and carcinogenicities of chronically inhaled diesel exhaust and carbon black in F344 rats. Fundam Appl Toxicol 25: 80-94, 1995.

29. Henle ES, Linn S. Formation, prevention, and repair of DNA damage by iron/hydrogen peroxide. $J$ Biol Chem 272 19095-19098, 1997 
30. Hampton MB, Kettle AJ, Winterbourne CC. Inside the neutrophil phagosome: oxidants, myeloperoxidase, and bacterial killing, Blood 92: 3007-3017, 1998.

31. Spencer JPE, Whiteman M, Jenner A, Halliwell B. Nitrite-induced deamination and hypochlorite-induced oxidation of DNA in intact human respiratory tract epithelial cells. Free Rad Biol Med 28: 1039-1050, 2000.

32. Weiss SJ. Tissue destruction by neutrophils. New Eng J Med 320: 365-376, 1989.

33. Schins RPF, Emmen H, Hoogendijk L. Borm PJA. Nasal inflammatory and respiratory parameters in human volunteers during and after repeated exposure to chlorine. Eur Respir J16: 626-632, 2000.

34. Calderón-Garciduenas L. Wen-Wang L. Zhang YJ, Rodriguez-Alcaraz A, Osnaya N, Villareal-Calderón A, Santella RM. 8-Hydroxy-2'-deoxyguanosine, a major mutagenic oxidative DNA lesion, and DNA strand breaks in nasal respiratory epithelium of children exposed to urban pollution. Environ Health Persp 107: 469-474, 1999.

35. Graham DE, Koren HS. Biomarkers of inflammation in ozone-exposed humans. Comparison of the nasal and bronchoalveolar lavage. Am Rev Respir Dis 142: 152-156, 1990.

36. Kunkel SL. Standiford T, Kasahara K, Strieter RM. Interleukin-8 (IL-8), the major neutrophil chemotactic factor in the lung. Exp Lung Res 17: 17-23, 1991.

37. Steerenberg PA, Fischer PH, van Bree L, van Loveren H. Nasal lavage biomarkers in air pollution epidemiology. Arch Toxicol Suppl 19: 207-216, 1997.

38. Steerenberg PA, Fischer PH, Gmelig Meyling F, Willighagen J, Geerse E, van de Vliet H, Ameling C, Boink AB, Dormans JA, van Bree L. van Loveren H. Nasal lavage as tool for health effect assessment of photochemical air pollution. Hum Exp Toxicol 15: 111-119, 1996.

39. Simon RH. DeHart PD, Todd III RF. Neutrophil-induced injury of rat pulmonary alveolar epithelial cells. $J$ Clin Imvest 78: $1375-1386,1986$.

40. Frischer T, Pullwitt A, Kuhr J, Meinen R, Haschke N, Studnicka M, Lubec G. Aromatic hydroxylation in nasal lavage fluid following ambient ozone exposure. Free Rad Biol Med 22: 201-207, 1997. 


\title{
Chapter 7
}

\section{DNA damage in lung epithelial cells isolated from rats exposed to quartz: role of surface reactivity and neutrophilic inflammation}

\author{
Ad M Knaapen', Catrin Albrecht' , Andrea Becker', Doris Höhr', Astrid Winzer', \\ Guido R Haenen², Paul JA Borm', Roel PF Schins'.
}

'Department of Fibre \& Particle Toxicology. Medical Institute of Environmental Hygiene, Düsseldorf, Germany. ${ }^{2}$ Department of Pharmacology and Toxicology,

Maastricht University, Maastricht, The Netherlands

\begin{abstract}
Respirable quartz has been classified as a human lung carcinogen (IARC, 1997). However, the mechanisms involved in quartz-induced carcinogenesis are still unclear. The aim of the present study was to investigate acute DNA damage in epithelial lung cells from rats exposed to quartz. Since surface reactivity is considered to play a crucial role in the toxicity of quartz, the effect of surface modifying agents polyvinylpyridine- $\mathrm{N}$-oxide (PVNO) and aluminium lactate (AL) was evaluated. Therefore, rats were instilled with quartz (DQ12, $2 \mathrm{mg} / \mathrm{rat}$ ) or quartz treated with PVNO or AL. After 3 days animals were sacrificed and brochoalveolar lavage (BAL) was performed to evaluate inflammatory cell influx (neutrophils and alveolar macrophages). BAL-fluid levels of lactate dehydrogenase (LDH), alkaline phosphatase (AP) and total protein were used as lung damage markers. Neutrophil presence and activity was also assessed by myeloperoxidase (MPO) measurement, and total antioxidant capacity of the BAL-fluid was determined using the TEAC (trolox equivalent antioxidant capacity) assay. Lung epithelial cells were isolated and DNA strand breakage was determined by single cell gel electrophoresis (comet assay). DNA damage was significantly increased in epithelial cells from rats instilled with DQ12, whereas no enhanced DNA strand breakage was observed when quartz was treated with PVNO or AL. Total protein, $\mathrm{LDH}$ and TEAC were increased in rats treated with native quartz, and this was inhibited by both coatings. A significant correlation between neutrophil numbers and MPO levels was observed, suggesting neutrophil activity. Inhibition of DNA damage by both coatings was paralleled by a reduction of neutrophil influx as well as MPO activity. In this study we provide evidence that modification of the particle surface prevents DNA strand breakage in epithelial lung cells from quartzexposed rats. Furthermore, the present data show the feasibility of our in vivo model to evaluate the role of inflammation, antioxidant status, and cytotoxicity in particle-induced DNA damage.
\end{abstract}

Based on: Carcinogenesis 23: 1111-1120, 2002. 


\section{Introduction}

Chronic exposure to quartz (crystalline silica) has been shown to result in tumour formation in the peripheral lung of the rat (1-5). Together with the observation that occupational exposure to quartz is associated with an elevated lung cancer risk in humans this has led to the classification of quartz as a Group 1 carcinogen by the International Agency for Research on Cancer (6). However, at present the exact mechanisms involved in quartz-induced carcinogenicity are still incompletely understood (7).

It is generally accepted that phagocytic cells, and more specifically reactive oxygen species (ROS) released by these cells, are involved in the link between inflammation and cancer $(8,9)$. For particle-induced carcinogenesis for instance, it has been demonstrated that tumour formation in rats was paralleled by the degree of chronic neutrophilic inflammation (10). In considering the possible mechanism of quartz-induced carcinogenicity it is important to note that carcinogenesis is a complex outcome of several consecutive events leading to the formation of a tumour (11). Although in vivo mutagenic effects have been demonstrated after quartz exposure $(12,13)$, only few studies focussed on more upstream processes, such as acute in vivo DNA damage, which is a prerequisite for mutagenicity. Yamano et al (1995) found an increased level of the oxidative DNA lesion 8-hydroxydeoxyguanosine (8-OHdG) in whole lung tissue from rats exposed to quartz (14), whereas others demonstrated the induction of 8$\mathrm{OHdG}$ more specifically in the alveolar region $(15,16)$. These studies suggested that $8-\mathrm{OHdG}$ induction was associated with a parallel influx of neutrophils into the lung. A possible role of neutrophils has been confirmed by our recent work, showing that isolated neutrophils were able to induce 8-OHdG in lung type II epithelial cells in vitro (17).

When considering quartz-induced DNA damage and its possible role in carcinogenicity it should be emphasised that surface reactivity is one of the key factors contributing to the pathogenicity associated with quartz inhalation $(7,18,19)$. For instance, in the past decades various in vivo studies demonstrated that quartz-induced silicosis could be inhibited by the administration of compounds such as aluminium salts and polyvinylpyridine$\mathrm{N}$-oxide, which are known to modify the surface reactivity of the quartz particles (20-24). In general, the reactivity of the particle surface is closely related to the ability of quartz to generate ROS $(19,25,26)$. Since ROS are implicated in both DNA damage and carcinogenesis (27) we hypothesised that the particle surface is also involved in DNA damage caused by quartz. Indeed, using in vitro studies we recently demonstrated that intrinsic ROS generation of quartz was closely related to DNA strand break formation in lung epithelial cells (28). More specifically, we and others showed that quartz-induced genotoxic effects could be reduced by inactivation of its reactive particle surface using surface modifying agents $(28,29)$. However, the implications of such primary genotoxic effects of quartz for lung target cells in vivo are still open for research and currently, excessive and persistent formation of ROS by inflammatory cells is thought to be a key factor in quartz-related genotoxic effects $(4,6,10,30)$. Also in this mechanism of secondary genotoxicity, surface reactivity of quartz might play an important role. For instance, it was demonstrated that the ability of inflammatory cells to release ROS upon quartz exposure in vitro could be mediated by using various surface modifying methods such as grinding or coating $(31,32)$. Additionally, we and others found that the influx of inflammatory cells into the rat lung was reduced when quartz was treated with surface modifying agents such as aluminium lactate or polyvinylpyridine- $\mathrm{N}$ oxide $(26,33,34)$.

Although these studies indicate that the reactivity of the quartz particle surface is implicated in several processes possibly involved in quartz-induced genotoxicity, the role of the particle surface in quartz-induced DNA damage in vivo has not yet been investigated. The aim of the present study was to investigate whether quartz (DQ12) could induce acute DNA 
damage in lung target cells in vivo and to elucidate whether this process could be mediated by surface modification of the quartz particles. More specifically, we hypothesised that surface modification of quartz would prevent DNA damage in epithelial lung cells via an inhibition of inflammatory cell influx into the lung. Therefore, rats were exposed to native quartz or quartz treated with either polyvinylpyridine- $\mathrm{N}$-oxide (PVNO) or aluminium lactate (AL). After three days DNA strand breakage was assessed in epithelial target cells freshly isolated from the lung. Additionally, to characterise the role of inflammatory cells, epithelial DNA damage was related to the presence and activation status of macrophages and neutrophils in the lung.

\section{Materials and Methods}

\section{Chemicals}

2-2'-azinobis-(-3 ethylbenzothiazoline-6-sulphonate) (ABTS), dimethyl sulphoxide (DMSO), Dulbecco's modified Eagle Medium (DMEM), ethidium bromide, L-glutamine, Hank's balanced salt solution (HBSS), Ham's F12 medium, HEPES buffer, fetal calf serum (FCS), lucigenin, 3-(4,5-dimethylthiazol-2-yl)-2,5-diphenyltetrazolium bromide (MTT), penicillin/streptavidin solution, percoll, phosphate buffered saline (PBS), trypsin and Trypsin/EDTA solution, were all obtained from Sigma (St. Louis, MO). Agarose, Low melting point agarose, horseradish peroxidase (HRPO), guaiacol, phorbol-12-myristate-13acetate (PMA) were also purchased from Sigma. ABAP (2,2'-azobis-(-2-amidinopropane) $\mathrm{HCl}$ was from Polysciences, Warrington, USA. DNAse I was purchased from Roche, Mannheim, Germany. All other chemicals were from Merck (Germany) and were of highest purity.

\section{Surface treatment of quartz}

Quartz (DQ12, batch 6, MIU, Düsseldorf) was baked at $215^{\circ} \mathrm{C}$ for $14 \mathrm{hr}$ to inactivate endotoxin. Surface modification was performed by suspending the baked DQ12 at $5 \mathrm{mg} / \mathrm{ml}$ in a $1 \%$ dilution of either PVNO (23) or aluminium lactate (Sigma-Aldrich, Germany), dissolved in distilled deionised sterile water, based on protocols originally described by Gabor et al, 1975 (35) and Bégin et al, 1986 (33), with minor modifications. Uncoated DQ12 was suspended in water without any additions. Preparations were sonicated for 5 minutes (Sonorex TK52 waterbath; 60 Watt, $35 \mathrm{kHz}$ ) and subsequently agitated for $5.5 \mathrm{~h}$ at room temperature, spun at $1000 \mathrm{~g}$, and washed 3 times with distilled sterile water by centrifugation $(1000 \mathrm{~g})$. The washed particles were finally resuspended in sterile water at a concentration of $5 \mathrm{mg} / \mathrm{ml}$, and aliquots of $1 \mathrm{ml}$ in sterile glass tubes were allowed to evaporate under a laminar flow chamber. All quartz processing was performed under sterile conditions. A single batch of quartz and coated quartz was prepared and used for the whole study to avoid effects induced by a possible variable coating efficiency. Transmission electron microscopy was used to determine whether treatment with aluminium lactate or PVNO caused changes in particle size distribution or aggregation of the DQ12, but no differences were found (data submitted elsewhere). The efficiency of the aluminium lactate coating procedure, which is defined as the amount of adsorbed aluminium per $\mathrm{mg}$ quartz, was investigated by atomic absorption spectrometry analysis following $3 \mathrm{~h}$ treatment of the coated quartz in $1 \mathrm{M} \mathrm{HNO}_{3}$ at $80^{\circ} \mathrm{C}$. The coating efficiency of PVNO was measured by spectrophotometric determination $(260 \mathrm{~nm})$ of the desorbed PVNO upon $3 \mathrm{~h}$ treatment in $1 \mathrm{M} \mathrm{NaOH}$ at room temperature against a PVNO standard. The estimated adsorbed amounts on the quartz were found to be $11 \mu \mathrm{g} \mathrm{PVNO} / \mathrm{mg}$ quartz and $1.6 \mu \mathrm{g}$ aluminium $/ \mathrm{mg}$ quartz. For intratracheal instillation, the dried quartz preparations were resuspended in $1 \mathrm{ml}$ of PBS (without $\mathrm{Mg}^{++}$and $\mathrm{Ca}^{++}$) and sonicated in a sonicating waterbath (Sonorex TK52; $60 \mathrm{Watt}, 35 \mathrm{kHz}, 5 \mathrm{~min}$ ). For in vitro experiments, the dried dusts were resuspended in HBSS or Ham's F12 medium. 


\section{Lucigenin-enhanced chemiluminescence}

Human neutrophils were exposed to native DQ12 quartz or DQ12 treated with PVNO or AL and superoxide release was assessed using lucigenin-enhanced chemiluminescence. Therefore, human peripheral blood neutrophils were isolated as described previously (36) and suspended in HBSS at $2 \times 10^{6}$ cells $/ \mathrm{ml}$. From this suspension, $50 \mu \mathrm{l}$ was added to a white maxisorp 96-well plate (Nunc, Germany) and mixed with $50 \mu \mathrm{l}$ of a quartz suspension ( 1 or $0.2 \mathrm{mg} / \mathrm{ml})$. Finally $100 \mu \mathrm{l}$ lucigenin $\left(5 \times 10^{-4} \mathrm{M}\right)$ was added. PMA $(100 \mathrm{ng} / \mathrm{ml})$, was used as a positive control. Lucigenin-enhanced chemiluminescence was then recorded using a luminometer (Multi-Bioluminat, Berthold, Germany), at $37^{\circ} \mathrm{C}$. Chemiluminescence output was recorded for $40 \mathrm{~min}$ and was expressed as area under the curve. All stimulatory agents and appropriate controls were tested in parallel and the experiment was repeated 3 times.

\section{In vitro cytotoxicity in RLE cells using MTT-assay}

Immortalised rat lung epithelial type II cells (RLE) (37) were kindly provided by Dr. K. Driscoll. Cells were cultured in Ham's F12 medium supplemented with $1 \% 1 \mathrm{M}$ HEPES buffer, $1 \%$ penicillin/streptomycin solution (Sigma), 1\% L-Glutamine solution ( $200 \mathrm{mM}$ ), and $5 \%$ heat-inactivated foetal calf serum (FCS) at $37^{\circ} \mathrm{C}$ and $5 \% \mathrm{CO}_{2}(17)$. Cells were routinely grown in $75 \mathrm{~cm}^{2}$ cell culture flasks and passaged twice a week. Experiments were performed between passage numbers 40-50. Cytotoxicity of both native and coated quartz was evaluated using the MTT-colorimetric assay according to Mosmann et al. (38), which was described previously (36). Briefly, cells were seeded in 96 well plates at 20,000 cells $/ 200 \mu \mathrm{l}$ in each well. At confluency, quartz preparations were suspended in F12 medium $(100 \mu \mathrm{l})$ without FCS and penicillin/streptomycin, added to the cells and incubated $\left(37^{\circ} \mathrm{C}, 5 \% \mathrm{CO}_{2}\right)$. After $4 \mathrm{~h}$, $25 \mu \mathrm{l}$ of 3-(4,5-dimethylthiazol-2-yl)-2,5-diphenyl-tetrazolium (MTT, $2 \mathrm{mg} / \mathrm{ml}$ ) dissolved in PBS, was added and cells were incubated for another $3 \mathrm{~h}$. Finally, solutions were removed, formazan chrystals were dissolved in DMSO $(200 \mu \mathrm{l})$ and absorption was measured using a microplate reader (Labsystems) at $540 \mathrm{~nm}$. Toxicity was calculated as \% of control from 3 individual experiments.

\section{Quartz instillation and bronchoalveolar lavage}

Specific pathogen free female Wistar rats were used for the investigations (Janvier, Le Genest St. Isle, France). Rats were maintained under controlled environmental conditions with a $12 \mathrm{~h}$ dark/light cycle. Food and water were available at libithum. When 8 weeks old (weighing 200-250 g), animals were lightly anaesthetised with isoflurane and intratracheal instillation was performed using a laryngoscope. From the quartz or coated-quartz suspensions $(5 \mathrm{mg} / \mathrm{ml}$ in PBS) $400 \mu \mathrm{l}$ was instilled giving a final dose of $2 \mathrm{mg}$ per rat $(\mathrm{n}=5$ per treatment $)$. Control rats were instilled with only PBS. After 3 days animals were sacrificed by a single i.p. injection of Na-pentobarbital and subsequent exsanguination via the abdominal aorta. Then, the lung was cannulated via the trachea and bronchoalveolar lavage (BAL) was performed. Epithelial cells were isolated from the same lung as will be described below. BAL was performed in situ by infusing the lungs with $5 \mathrm{ml}$ aliquots of PBS. The BAL fluid (BALf) was drained passively by gravity and the procedure was repeated four times, giving a total BAL volume of $20 \mathrm{ml}$. Total cell number in the BALf was analysed using a hemocytometer chamber (Neubauer) and viability was assessed by trypan blue dye exlcusion. BAL-cell differential was determined on cytospin preparations stained with May-Grünwald/Giemsa (MGG). The BAL fluid (BALf) was centrifuged twice ( $300 \mathrm{~g}$ to collect cells, followed by $1000 \mathrm{~g}$ to obtain BALf), and the acellular supernatant was analysed for lung injury parameters (total protein, alkaline phosphatase, lactate dehydrogenase), and myeloperoxidase. 


\section{Measurement of BAL parameters}

Total protein was analysed according to the method described by Lowry. Alkaline phosphatase and lactate dehydrogenase were assayed using diagnostic kits from Merck (Germany). MPO activity in the BAL fluid was assayed according to Klebanoff et al (39). Briefly, $200 \mu \mathrm{l}$ of unconcentrated cell-free BALf was mixed with $800 \mu \mathrm{l}$ MPO assay solution. This was prepared freshly before use, containing $107.6 \mathrm{ml} \mathrm{H}_{2} \mathrm{O}, 12 \mathrm{ml} 0.1 \mathrm{M}$ sodium phosphate buffer, $0.192 \mathrm{ml}$ Guaiacol, $0.4 \mathrm{ml} 0.1 \mathrm{M} \mathrm{H}_{2} \mathrm{O}_{2}$. The generation of tetra-guaiacol was measured spectrophotometrically (Beckman) at $470 \mathrm{~nm}$ and the change of optical density per minute was calculated from the initial rate. The MPO acitivity was then calculated from the formula: $\mathrm{U} / \mathrm{ml}=\square \mathrm{OD} /$ minute $\times 0.752$ and expressed as $\mathrm{mU} / \mathrm{ml}$. One unit of the enzyme is defined as the amount that consumes $1 \mu \mathrm{mol} \mathrm{H}_{2} \mathrm{O}_{2}$ per minute.

\section{Trolox equivalent antioxidant capacity assay}

The TEAC (trolox equivalent antioxidant capacity) assay was performed according to Van den Berg et al. (40) with minor modifications. An ABTS (2-2'-azinobis-(-3 ethylbenzothiazoline-6-sulphonate) radical solution was prepared by mixing $2.5 \mathrm{mM}$ ABAP $\left(2,2^{\prime}\right.$-azobis-(-2-amidinopropane $) \mathrm{HCl}$ with $20 \mathrm{mM} \mathrm{ABTS}$ solution in $150 \mathrm{mM}$ phosphate buffer ( $\mathrm{pH} \mathrm{7.4)} \mathrm{containing} 150 \mathrm{mM} \mathrm{NaCl}$. The solution was heated for $10 \mathrm{~min}$ at $70^{\circ} \mathrm{C}$ and, if necessary, diluted to obtain a solution with an absorbance at $734 \mathrm{~nm}$ between 0.68 and 0.72 . For measuring antioxidant capacity $100 \mu \mathrm{l}$ of the cell-free BALf was mixed with $900 \mu \mathrm{l}$ of the ABTS radical solution. Both native BAL fluid and deproteinised fluid ( $10 \%$ TCA) were tested. The decrease in absorbance at $734 \mathrm{~nm} 5$ minutes after addition of the sample was used for calculating the TEAC. Trolox was used as reference compound. The TEAC of the sample is given as the concentration of a trolox solution that gives a similar reduction of the absorbance at $734 \mathrm{~nm}$.

\section{Epithelial cell isolation}

Lung epithelial cells were isolated according to the method developed by Richards et al. (41) with modifications. After BAL, lungs were removed from the rat and pre-washed with $5 \mathrm{ml}$ trypsin via the cannula $\left(37^{\circ} \mathrm{C}, 2.5 \mathrm{mg} / \mathrm{ml}\right.$ dissolved in $\mathrm{PBS}$ with $\mathrm{Ca}^{++}$and $\left.\mathrm{Mg}^{++}\right)$. The cannulated lung was subsequently attached to a syringe in a retord stand and filled with trypsin solution. The lungs were left for $30 \mathrm{~min}$ at $37^{\circ} \mathrm{C}$, during which the level of trypsin is constantly 'topped up'. After trypsination the lungs were transferred into a sterile petri dish and the trachea and the main bronchi were dissected free. The remaining lung parenchymal tissue was chopped with scissors into small pieces (approximately $1 \mathrm{~mm}$ ) and FCS $(5 \mathrm{ml}$ ) was added to inactivate the trypsin. In all subsequent steps lung preparations and solutions were kept at $4^{\circ} \mathrm{C}$ to avoid post-experimental DNA repair. The volume of the lung homogenates was adjusted to $20 \mathrm{ml}$ with PBS and DNAse I ( $500 \mu \mathrm{l}$ of $4 \mathrm{mg} / \mathrm{ml}$ solution) was added followed by shaking $(5 \mathrm{~min})$ to prevent cell-clotting. The lung tissue homogenate was subsequently filtered through gauze followed by filtration through nylon filters (150 and $30 \mu \mathrm{m}$ respectively), and the final filtrate (adjusted to $20 \mathrm{ml}$ with PBS) was layered onto a discontinued Percol gradient of heavy density $(1 \mathrm{ml} 10 \mathrm{x}$ concentrated PBS, $2.5 \mathrm{ml}$ distilled water, $6.5 \mathrm{ml}$ Percoll-1.13 g/ml) and light density $(1 \mathrm{ml} 10 \mathrm{x}$ concentrated PBS, $6.3 \mathrm{ml}$ distilled water, $2.7 \mathrm{ml}$ Percoll). Preparations were centrifuged for 20 minutes at $300 \mathrm{~g}\left(4^{\circ} \mathrm{C}\right)$. After separation, the layer containing the epithelial cells (4th from top) was carefully removed, washed with PBS and resuspended in DMEM medium supplemented with $10 \%$ FCS, $1 \%$ penicillin/streptavidin solution (Sigma) and $1 \%$ L-glutamine $(200 \mathrm{mM})$. The cells were then plated into $100 \mathrm{~mm}$ petri-dishes to further enrich the epithelial cell fraction by allowing contaminating fibroblasts, macrophages and neutrophils to attach to the surface. After $1 \mathrm{~h}$ incubation at $37^{\circ} \mathrm{C}$ and $5 \% \mathrm{CO}_{2}$, the supernatant was removed and centrifuged ( 300 
g) to collect non-attached epithelial cells. Centrifuged cells were resuspended in $500 \mu \mathrm{l}$ DMEM (cold) and were counted using a Neubauer chamber, while cell viability was determined by trypan blue dye exclusion.

\section{Characterisation of isolated epithelial cells}

The percentage of epithelial cells present in the isolated fractions was determined using 3 different methods. First, the proportion of epithelial cells, alveolar macrophages, neutrophils and possible other cells was investigated using MGG staining of cytospin preparations and subsequent differential counting by an experienced observer. Secondly, identification of type II epithelial cells specifically was done by staining for alkaline phosphatase activity, as described by Bingle et al (42). Therefore, cytospin preparations were dried on air and then stained with naphtol ( $10 \mathrm{mg}$, dissolved in $40 \mu \mathrm{l}$ DMSO), added to $0.125 \mathrm{M} \mathrm{2-amino-2-methyl-}$ 1-propanol buffer ( $\mathrm{pH} \mathrm{9-10).} \mathrm{Directly} \mathrm{before} \mathrm{use} 10 \mathrm{mg}$ fast red was added and cells were incubated for 15 minutes at room temperature to the filtered solution $(0.4 \mu \mathrm{m})$. Slides where washed with distilled water, cells were counterstained with haematoxilin and type II cells were counted using light microscopy. However, definite characterisation of the different isolated epithelial cells is only possible using electron microscopy. Therefore, epithelial cells from a PBS-instilled animal were isolated as described previously and centrifuged cell pellets were fixed with $2.5 \%$ glutaraldehyde in $0.1 \mathrm{M}$ cacodylate buffer for $1 \mathrm{hr}\left(4^{\circ} \mathrm{C}\right)$. After washing with $0.1 \mathrm{M}$ cacodylate buffer and postfixation with $2 \% \mathrm{OsO}_{4}$, cell preparations were encapsulated in agar ( $2 \%$ in PBS). The ice cooled agar blocks were cut in cubes and dehydrated in graded ethanol series. Poststaining en bloc was accomplished with $1.5 \%$ uranlyacetate and phosphoric tungsten in $70 \%$ ethanol. Absolute ethanol was replaced with propylene oxide and the agar cubes were embedded in epon (Serva, Heidelberg) (43), thinsectioned (Reichert, Ultracut) and examined using a transmission electron microscopy (TEM, Philips, CM12) equipped with a digital imaging system (SIS, Münster, Germany).

\section{Single cell gel electrophoresis (comet assay)}

DNA strand breakage in epithelial cell preparations was assayed immediately after cellisolation by the comet-assay $(44,45)$, according to the guidelines recently proposed by an expert panel (46). Fully frosted slides were covered with a layer of $100 \mu \mathrm{l} 0.65 \%$ agarose using a coverslip and stored overnight at $4^{\circ} \mathrm{C}$. Epithelial lung cells were isolated as described above and $25 \mu \mathrm{l}$ cell suspension $\left(2 \times 10^{6}\right.$ cells $\left./ \mathrm{ml}\right)$ was mixed with $75 \mu \mathrm{l} 0.5 \%$ low melting point agarose, and added to the slides, on top of the first agarose layer using a coverglass. Slides were stored at least 45 minutes at $4^{\circ} \mathrm{C}$ to allow solidification, and then covered with another layer of the low melting point agarose $(100 \mu \mathrm{l})$. Following solidification for another 45 minutes at $4^{\circ} \mathrm{C}$, coverglasses were removed, slides were immersed in lysis buffer $(2.5 \mathrm{M}$ $\mathrm{NaCl}, 100 \mathrm{mM}$ EDTA, $10 \mathrm{mM}$ Tris-base, $1 \%$ sodium lauryl sarcosinate, $\mathrm{pH} 10 ; 10 \%$ DMSO and $1 \%$ Triton X-100 added just before use) and stored overnight at $4^{\circ} \mathrm{C}$. The following day, slides were rinsed with distilled water and placed in an electrophoresis tank filled with icecold electrophoresis buffer $(300 \mathrm{mM} \mathrm{NaOH}, 1 \mathrm{mM}$ EDTA, pH 13) for 30 minutes. Electrophoresis was conducted at $300 \mathrm{~mA}$ and $25 \mathrm{~V}$ for 15 minutes. Slides were neutralised $3 \mathrm{x}$ $10 \mathrm{~min}$ using neutralisation buffer $(0.4 \mathrm{M}$ Tris, $\mathrm{pH} 7.5)$. All steps after cell lysis were performed in the dark or under dimmed red light to prevent additional DNA damage. Finally, slides were stained with ethidium bromide $\left(20 \mu \mathrm{g} / \mathrm{ml}\right.$ in $\left.\mathrm{H}_{2} \mathrm{O}\right)$ and comet appearances were analysed using an Olympus BX60 fluorescence microscope at $1000 \mathrm{x}$ magnification. For each individual animal, 3 slides were prepared and on every single slide 50 cells were analysed randomly, and classified into one out of five categories according to tail length (I,II,III,IV, and $\mathrm{V}$, in which $\mathrm{I}=$ undamaged cells without comet tail) (47). For final analysis the percentage of cells exhibiting comet tails (class II-V cells) was used. 


\section{Statistical analysis}

Data are expressed as mean \pm SEM, unless stated otherwise. Statistical analysis was performed using SPSS v. 10 for Windows. Student T-test was applied to test differences between exposed and unexposed groups. Correlations between DNA damage and neutrophilic inflammation or lung toxicity markers were tested using Pearson. Differences were considered to be statistically significant when $\mathrm{p}<0.05$.

\section{Results}

In vitro studies with native and coated quartz

Before starting with the animal studies we tested the efficacy of the surface treated quartzes in several in vitro systems. Isolated human neutrophils were exposed to quartz suspensions and lucigenin-enhanced chemiluminescence was applied to detect superoxide release $\left(\mathrm{O}_{2}{ }^{\circ}\right)$. Data are shown in Figure 1.

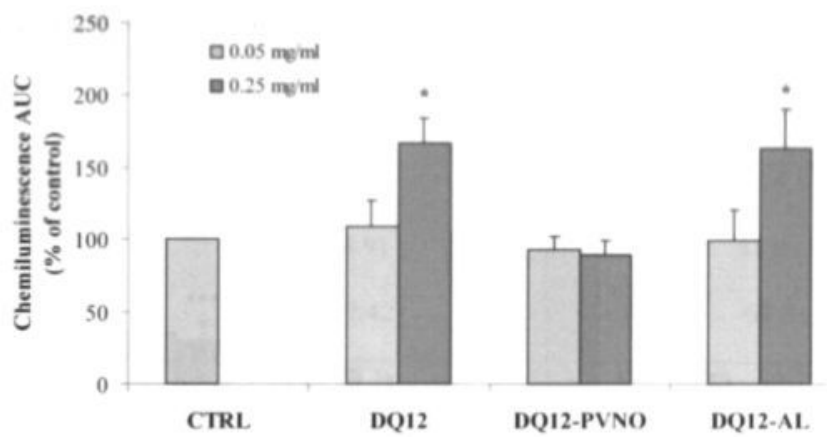

Figure 1. Lucigenin-enhanced chemiluminescence of human blood neutrophils exposed to DQ12 or DQ12 coated with PVNO or aluminium lactate (AL). Chemiluminescence was recorded for $40 \mathrm{~min}$. and expressed as area under the curve (AUC). Data are shown as mean \pm sd of 3 different experiments. "p 0.01 vs. control (=CTRL).

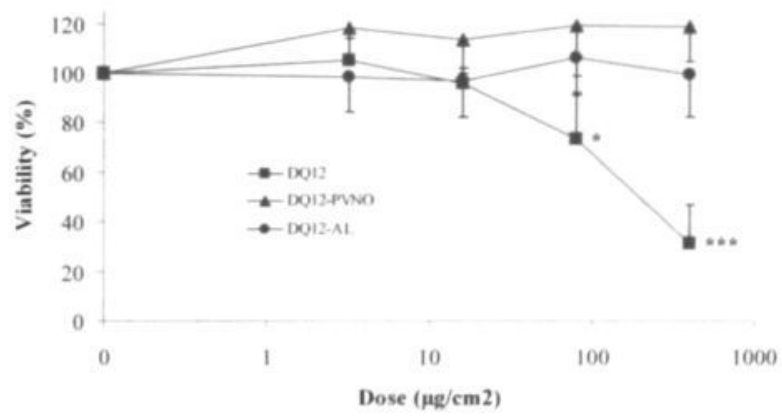

Figure 2. Viability of RLE cells exposed to native or coated DQ12. Viability was assessed using the MTT-assay and was expressed as $\%$ of control. Data shown represent mean \pm sd from 3 experiments. $p<0.05, \cdots p<0.001$ vs. control $\left(0 \mu \mathrm{g} / \mathrm{cm}^{2}\right)$. 
Generation of superoxide was enhanced by DQ12. At $0.25 \mathrm{mg} / \mathrm{ml}$ DQ12 quartz, chemiluminescence was increased with approximately $170 \%$ compared to control cells. This effect was inhibited when DQ12 was coated with PVNO, but not with AL. When PMA was used as a positive control, $\mathrm{O}_{2}{ }^{*}$ release was increased with $230 \%$ (not shown). The effect of both surface coatings on cytotoxicity induced by quartz was tested using the MTT assay. RLE cells were exposed for $4 \mathrm{~h}$ to DQ12 or coated quartz preparations at $0-400 \mu \mathrm{g} / \mathrm{cm}^{2}$. As shown in Figure 2, native quartz dose dependently reduced cell viability, whereas this toxicity was significantly inhibited upon treatment of DQ12 with AL or PVNO.

\section{Inflammogenic and cytotoxic effects detected in bronchoalveolar lavage}

Bronchoalveolar lavage was used to assess both inflammogenic and toxic effects after quartz exposure. Separate animals were also treated with $22 \mu \mathrm{g}$ PVNO and $35 \mu \mathrm{g}$ aluminium lactate, amounts calculated from the coating efficiency of both substances. However, these treatments did not have an effect on any of the studied BAL parameters (34). A significant increase of neutrophil numbers was observed after quartz exposure ( $p<0.001$ vs. control). When DQ12 was coated with PVNO the neutrophil influx was inhibited. Treatment with AL also reduced neutrophil influx, although this effect was less pronounced than for PVNO-coated DQ12 (Figure 3).

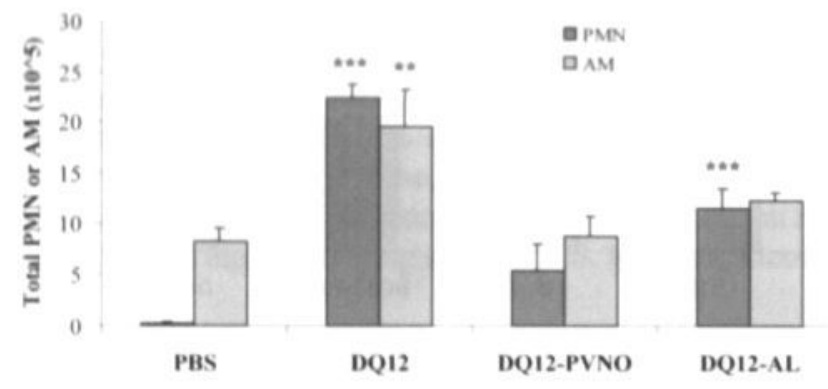

Figure 3. Total numbers of neutrophils (PMN) and macrophages (AM) in brochoalveolar lavage of rats 3 days after intratracheal instillation of $2 \mathrm{mg}$ of DQ12 or DQ12 coated with aluminium lactate (AL) or PVNO. Data are presented as mean \pm SEM (n-5). $\cdots p<0.001, \cdots p-0.01$ vs. PBS.

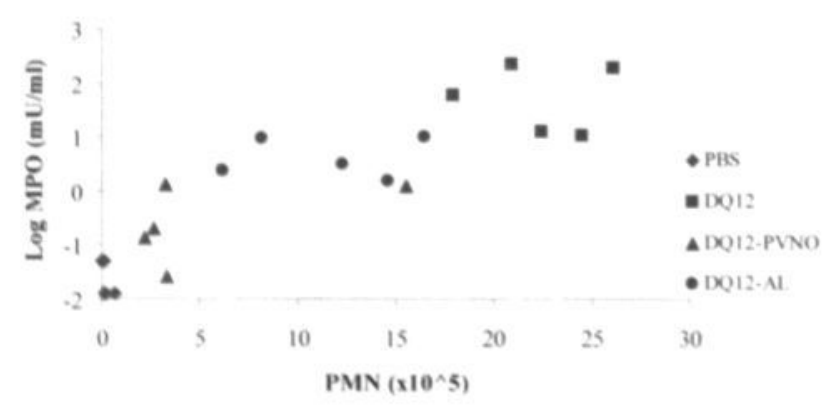

Figure 4. Correlation between total neutrophil numbers (PMN) and myeloperoxidase activity (MPO) in bronchoalveolar lavage fluid from rats 3 days after intratracheal instillation of 2 mg DQ12 or DQ12 coated with aluminium lactate (AL) or PVNO. Each point represents a single animal. Pearson correlation $=0.88, p-0.001$ 
The number of alveolar macrophages was increased only after instillation with native quartz ( $p<0.05$ vs. control). Further data of relevant BAL parameters are outlined in Table 1. To evaluate possible toxic effects of quartz exposure, total protein, alkaline phosphatase and lactate dehydrogenase were analysed in the BAL fluid. Total protein was only increased by native quartz, whereas LDH levels were significantly increased after exposure to both quartz or AL-treated quartz. No differences were observed for alkaline phosphatase activity in BAL fluid. MPO used as a specific marker of neutrophil presence and activity, was only increased by DQ12. Although neutrophil influx by DQ12-AL was significantly higher than in PBS treated animals (Figure 3), no significant induction of MPO activity levels was seen in these animals. However, on a single animal level, covering all treatments, a highly significant correlation is present between neutrophil numbers and MPO activity $(r=0.88, p<0.001)$ (Figure 4). Interestingly, when MPO activity was adjusted on neutrophil numbers present in the BAL fluid, the activity of MPO per neutrophil was about 8.5 times lower after DQ12-AL compared to native DQ12 (resp. $93.6 \pm 72.3$ and $796.5 \pm 772.0, \mathrm{p}<0.01$ ).

Table 1. Inflammatory and cytotoxicity markers analysed in brochoalveolar lavage 3 days after intratracheal instillation of DQ12 or DQ12 coated with PVNO or aluminium lactate (AL) (mean $\pm s d, n=5)$.

\begin{tabular}{lcccc}
\hline & PBS & DQ12 & DQ12-PVNO & DQI2-AL \\
\hline Total cells $\left(\mathrm{x} 10^{5}\right)$ & $8.9(2.5)$ & $48.0(9.2)^{* * *}$ & $16.1(12.2)$ & $27.72(4.9)^{* *}$ \\
Neutrophils $(\%)$ & $3.3(4.9)$ & $47.6(8.7)^{* * *}$ & $31.0(10.0)^{* * *}$ & $41.3(11.7)^{* * *}$ \\
Macrophages $(\%)$ & $93.0(7.42)$ & $38.9(11.34)^{* * *}$ & $60.8(14.9)^{* *}$ & $44.2(3.4)^{* * *}$ \\
\hline Total protein $(\mu \mathrm{g} / \mathrm{ml})$ & $13.2(3.3)$ & $46.9(21.4)^{*}$ & $32.7(37.1)$ & $30.6(18.2)$ \\
$\begin{array}{l}\text { Alkaline Phosphatase }(\mathrm{U} / \mathrm{ml}) \\
\text { LDH }(\mathrm{U} / \mathrm{ml})\end{array}$ & $9.4(2.5)$ & $12.3(2.7)$ & $9.7(2.6)$ & $12.2(2.9)$ \\
$\begin{array}{l}\text { MPO (mU/ml) } \\
\text { MPO/neutrophils } \\
\left(\mathrm{mU} / \mathrm{lx} 10^{6} \text { neutrophils) }\right.\end{array}$ & $25.7(7.8)$ & $120.4(38.1)^{* * *}$ & $34.0(7.2)$ & $59.8(11.5)^{*}$ \\
& $0.027(0.02)$ & $99.3(100.6)^{* *}$ & $0.54(0.59)$ & $5.3(4.1)$ \\
& $23.2(35.0)$ & $796.5(772.0)^{* *}$ & $23.3(30.5)$ & $93.6(72.3)$
\end{tabular}

LDH (lactate dehydrogenase), MPO (Myeloperoxidase)

***p $<0.001,{ }^{* *} \mathrm{p}>0.01,{ }^{*} \mathrm{p}<0.05$ vs. PBS

\section{Total antioxidant capacity in brochoalveolar lavage}

Trolox equivalent antioxidant capacity assay (TEAC-assay) was used to evaluate changes in the total antioxidant capacity in the BAL-fluid. Data are shown in Figure 5. Compared to control animals instilled with PBS, an increased antioxidant capacity was observed after all quartz treatments, although effects of quartz treated with either PVNO or AL were less pronounced. No changes in antioxidant capacity was detected when the BALf was deproteinised prior to use in the TEAC assay (levels were close to detection limit). TEAC in the native, unprocessed BALf from all treatments correlated with total number of neutrophils $(\mathrm{r}=0.81, \mathrm{p}<0.001)$, with macrophages present in the BALf $(\mathrm{r}=0.65, \mathrm{p}<0.01)$, with total protein levels $(\mathrm{r}=0.75, \mathrm{p}<0.001)$ and MPO activity $(\mathrm{r}=0.74, \mathrm{p}<0.001)$. 


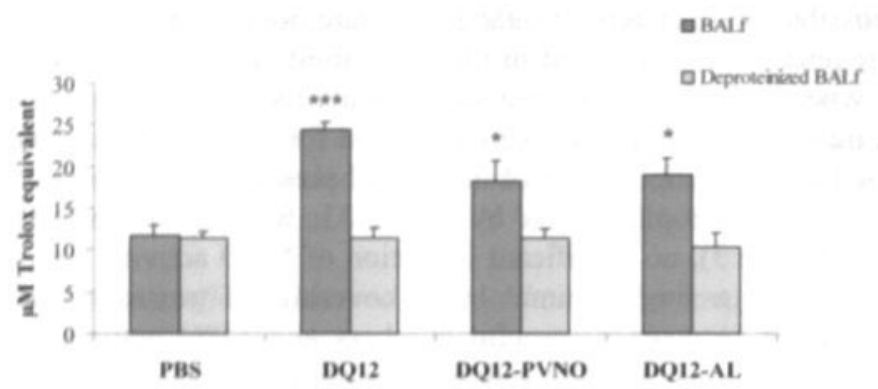

Figure 5. Trolox equivalent antioxidant capacity (TEAC) in bronchoalveolar lavage fluid (BALf) from rats 3 days after intratracheal instillation of DQ12 or DQ12 coated with aluminium lactate (AL) or PVNO. TEAC was measured both in native and deproteinised BAL.f. Data are presented as mean + SEM $(n=5)$. $\cdots * 0.001, " p<0.05$ vs. PBS.

\section{Characterisation of epithelial cell isolates}

After bronchoalveolar lavage, lungs were used to isolate epithelial cells. Yield of epithelial cell isolates is shown in Table 2. Using MGG-staining, a total differential counting was performed. The percentage of recovered epithelial cells appeared to be slightly lower for DQ12 treated rats compared to the other treatments, however this difference was not statistically significant. Mean percentage of type II pneumocytes was $38.6( \pm 6.5)$ in control rats, and this was reduced in isolates from rats exposed to either native DQ12 or coated DQ12. In Figure 6 representative electron microscopic pictures of different cells found in the isolates are shown. Differential countings in this preparation indicated that at least $65 \%$ of the cells appeared to be of an epithelial origin (13\% type II cells, $52 \%$ bronchial epithelial cells), which is in line with data obtained after analysis of the MGG-stainings. Other cells appeared to be mainly macrophages.

Table 2. Differential of epithelial-cell isolates from rat lungs after exposure for 3 days to native DQ12 or DQ12 coated with PVNO or aluminium lactate (AL). (mean + sd, $n=5$ ).

\begin{tabular}{lcccc}
\hline & PBS & DQ & DQ-PVNO & DQ-AL \\
\hline Yield (Total cells $\times 10^{5}$ ) & $34.3(3.5)$ & $68.5(20.4)^{*}$ & $39.4(15.4)$ & $67.5(28.3)^{*}$ \\
\% epithelial cells (MGG) & $75.0(6.4)$ & $62.5(6.6)$ & $68.3(14.9)$ & $73.8(9.4)$ \\
$\begin{array}{l}\text { \% Type II cells (Alkaline } \\
\text { phosphatase) }\end{array}$ & $38.6(6.5)$ & $20.7(14.7)^{*}$ & $22.3(8.5)^{*}$ & $19.2(9.0)^{*}$ \\
\% neutrophils (MGG) & $4.4(1.9)$ & $17.7(4.0)^{* *}$ & $11.6(9.0)$ & $11.3(9.0)$ \\
\% macrophages (MGG) & $19.6(6.1)$ & $19.1(7.1)$ & $18.0(6.6)$ & $13.2(2.0)$ \\
\hline
\end{tabular}

MGG (May-Girunwald Giemsa staining), evaluated with light microscopy.

* $p>0.01, " p=0.05$ is. PBS 

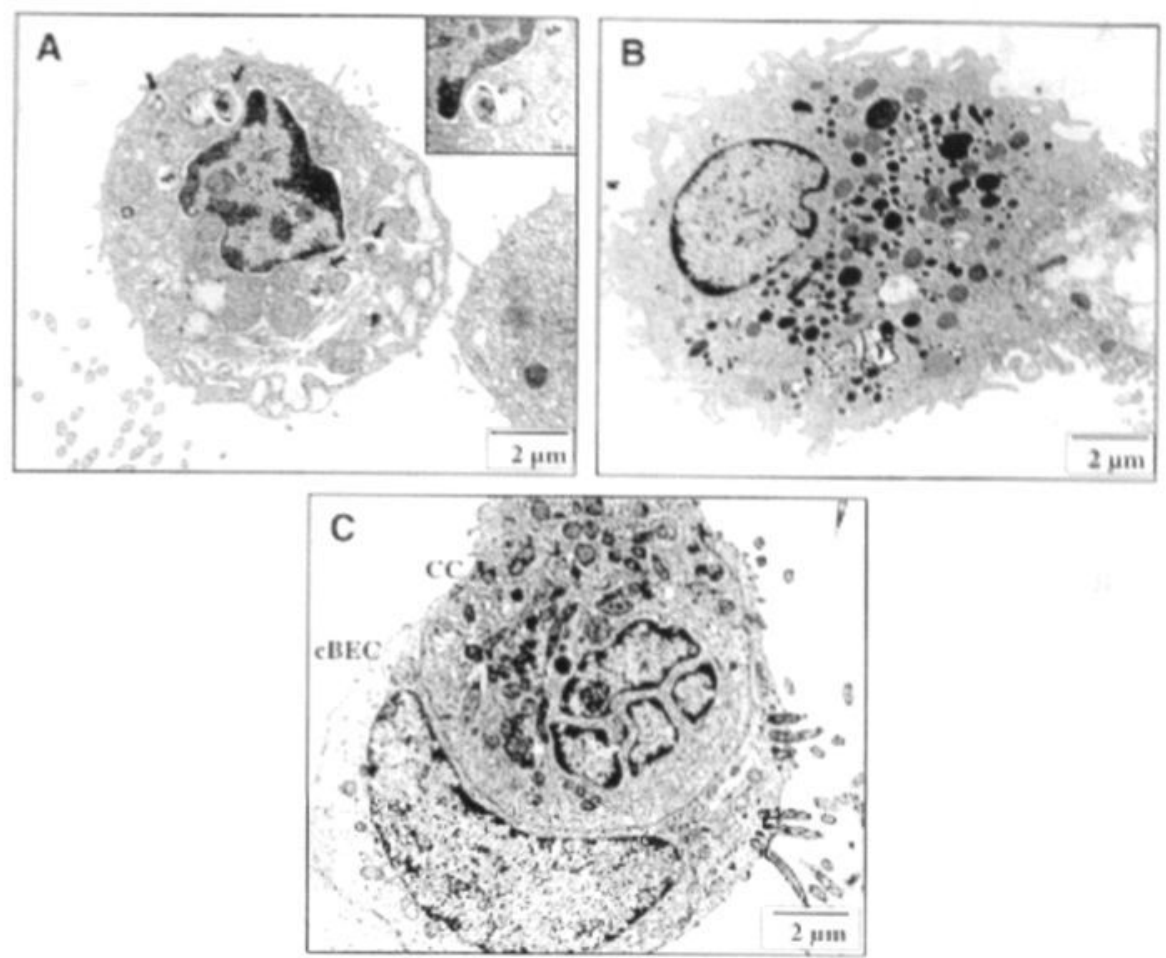

Figure 6. Representative pictures from electron microscopic analysis of cells found in epithelial cell isolates from rats. (A) Type II alveolar epithelial cell. Arrows and insert indicate lamellar bodies. (B) Alveolar macrophage. (C) Bronchial epithelial cells, two different cells are shown: $\mathrm{cBEC}=$ ciliated bronchial epithelial cell, $\mathrm{CC}=$ Clara cell.

\section{DNA damage in lung epithelial cell isolates}

Single cell gel electrophoresis was used to detect DNA strand break formation in the epithelial cell isolates. Data are shown in Figure 7. Quartz exposure caused a significant increase in DNA strand breakage in the isolated cells. Importantly, when quartz was treated with PVNO or AL no enhanced levels of DNA damage compared to PBS-treated rats were observed (Figure 7A). In Figure 7B the distribution of cells over the various comet classes (II to $\mathrm{V}$ ) is shown. The increased level of DNA damage by native quartz appears to be present in all comet classes. However, no differences were found in class V, representing the highest damaged cells. No relation was observed between DNA strand breakage and cell isolation characteristics such as the percentage of epithelial cells, type II cells, or neutrophils present in isolates. Viability analysis of the isolated cells, using trypan blue dye exclusion, showed that viability of cells used in the comet assay was always $>95 \%$, and no differences between exposure groups were observed (data not shown). No correlation was found between in vivo DNA damage and general lung toxicity reflected in total protein levels, alkaline phosphatase or lactate dehydrogenese activity in BAL-fluid. Moreover, no relation between antioxidant capacity (TEAC) and DNA strand breakage was found on a single animal level, pooling all treatments. 
A

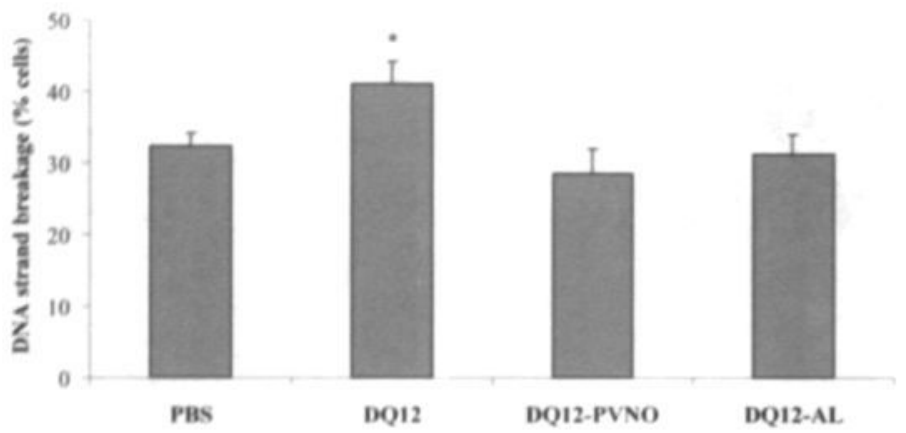

B

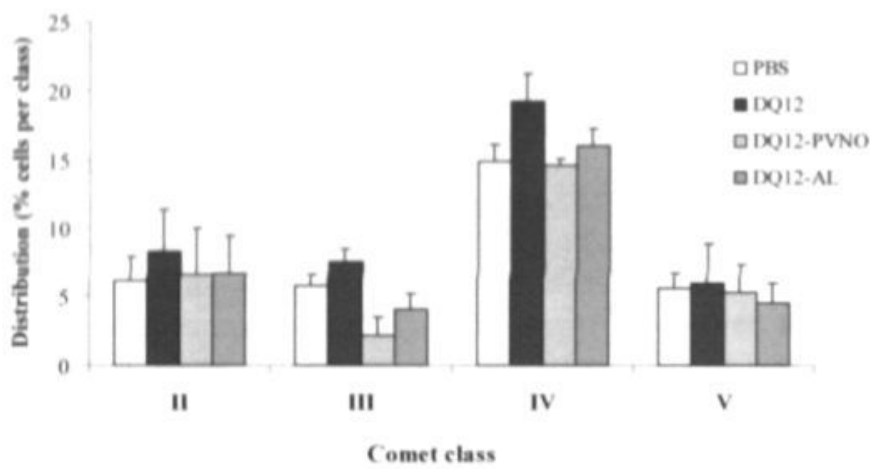

Figure 7. DNA strand breakage in epithelial cell isolates from rat lungs after intratracheal instillation of DQ12 or DQ12 coated with PVNO or aluminium lactate (AL). DNA strand break formation was assessed using the comet assay and was expressed as $\%$ of cells showing comet tails $(A)$. In figure $(B)$ the distribution of the damaged cells over the various comet classes (II-IV) is shown. Data are mean + SFM (n-5). " $p<0.05$ vs. PBS.

Since one of our objectives was to investigate the role of neutrophils in epithelial cell genotoxicity after quartz exposure, we related DNA damage (comet) to both neutrophil numbers and neutrophil activity, reflected in MPO levels in BALf. This relation is given in respectively Figure $8 \mathrm{~A}$ and $8 \mathrm{~B}$, and shows that only at high neutrophil numbers $\left(2 \times 10^{6}\right.$, corresponding with $48 \%$ of total BAL cells) or high MPO levels, both corresponding to treatment with native DQ12, epithelial DNA damage was increased. However, no correlation was found between either neutrophil influx or MPO levels and epithelial DNA damage in individual animals, both within different treatment groups $(n=5)$ and in all animals $(n=20)$. 

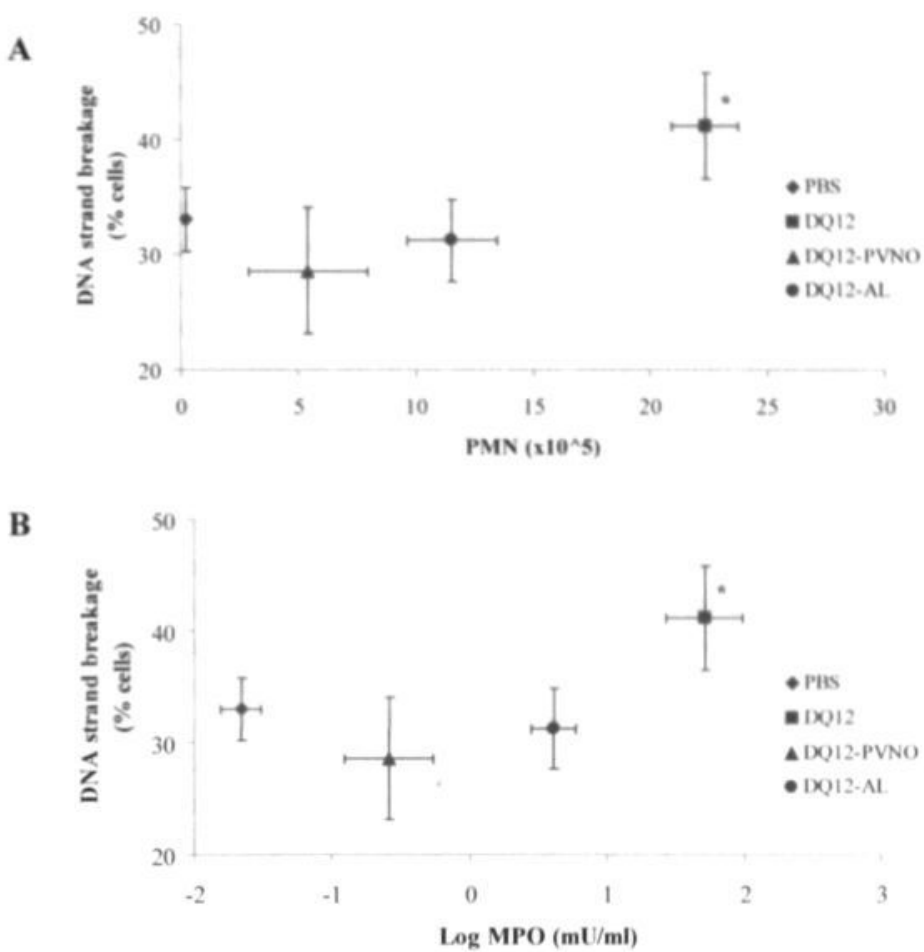

Figure 8. Relation between (A) neutrophil influx (PMN) or (B) myeloperoxidase activity (MPO) in BAL-fluid and DNA strand breakage in epithelial cell isolates from rats 3 days after instillation of DQ12 or DQ12 coated with PVNO or aluminium lactate (AL). Data are presented as mean \pm SEM $(n=5) . * 0<0.05$ vs. PBS.

\section{Discussion}

Quartz (crystalline silica) has recently been classified as a human lung carcinogen (6). However, the quartz hazard (eg. its ability to induce cancer) is by no means a constant entity, and its pathological effects may vary depending on its sources or inherent characteristics $(7,18,48)$. One important variable characteristic appears to be the surface reactivity of quartz. The role of particle surface reactivity in quartz-induced cytotoxicity, inflammogenicity and fibrogenicity has previously been demonstrated using various surface modifying procedures, such as coating with PVNO or aluminium salts (18,20,26,31,33-35,49-51). In early studies, PVNO and aluminium lactate were administered at high doses to prevent or treat quartzinduced silicosis $(21-24)$. In the present study however, both compounds were used to coat the quartz particles in order to specifically investigate the role of reactive surface functionalities in quartz-induced genotoxicity. We demonstrated that intratracheally instilled quartz (DQ12, $2 \mathrm{mg}$ ) causes acute induction of DNA strand breakage in lung epithelial cell isolates in vivo. However, this effect was not observed when quartz was treated with either PVNO or AL, suggesting an important role of the reactive particle surface in quartz-induced in vivo DNA damage. Since both surface modifications inhibited inflammatory cell influx as well DNA 
strand breakage, our data provide further support for the possible role of inflammatory cells in quartz-induced genotoxicity $(4,6,30)$.

In quartz-induced carcinogenesis in rats, oxidant release by lung phagocytes, and more specifically neutrophils, is reported to be an important factor $(4,10)$. In the present study we therefore analysed the role of the reactive quartz surface on inflammatory cell influx as a possible mediator of quartz-induced DNA damage. We clearly showed that neutrophil influx, induced by quartz was inhibited by both PVNO and, to a lesser extent, also by AL. The inhibitory effects of both coating materials on inflammatory cell influx are in line with observations in earlier studies using aluminium lactate $(26,33)$, and confirm the important role of the reactive particle surface in quartz-induced inflammation. In addition to neutrophil presence, we also assessed neutrophil activity by measuring the enzyme myeloperoxidase in BALf, since MPO is considered as a marker of neutrophil activition (52-54). Our data suggest that the quartz-induced influx of neutrophils into the lung is accompanied by a subsequent activation. Both neutrophil influx and MPO activity were inhibited by the coatings, although AL was less effective than PVNO. Interestingly, MPO activity expressed per neutrophil number seemed to be 8-fold higher in DQ12-treated rats than in rats instilled with DQ12-AL. This suggests a possible difference in the 'activation status' of neutrophils between the different treatments. Schmekel et al. (52) previously demonstrated that MPO measured in BALf is of local origin, rather than passively diffused from the blood. However, the increased levels of total protein and LDH activity in BALf from native DQ12-treated rats could imply a loss of membrane integrity, possibly leading to an influx of MPO from the capillary bed.

In addition to MPO release, activation of neutrophils is further characterised by a potent oxidative burst (53). In line with data from Hedenborg and Klockars (55), we showed that in vitro superoxide release by human neutrophils was abrogated when quartz was coated with PVNO. However, AL treatment of quartz did not inhibit superoxide release. These in vitro data led us to suggest that we had a feasible model to dissect between primary and inflammatory cell-mediated secondary genotoxicity after in vivo quartz exposure, since both coatings had a distinct effect on the neutrophils' oxidative burst. However, in vivo the differences between the coatings on inflammatory processes were less pronounced than anticipated, as they both inhibited inflammatory cell influx and activation.

It should be emphasised that the interaction of the two coating materials with the quartz surface is very different. PVNO is a polymer which is considered to interact with the quartz surface via $\mathrm{H}$-bonding of its $\mathrm{NO}$ groups with silanol groups $(18,50,56)$. On the other hand the mechanism of action of aluminium lactate is not fully clarified, although aluminium appears to affect the acidity and the solubility of the quartz, and has also been reported to hinder the formation of surface radicals and to block charges caused by grinding $(18,20,56)$. The inhibitory effect of the PVNO coating on in vitro ROS release by neutrophils is unlikely to be caused by its proposed antioxidant activity (57), as the adsorbed PVNO content was only $11 \mu \mathrm{g}$ per mg quartz. Even if released from the particle surface, this amount was found not to have any detectable antioxidant activity as determined by electron spin resonance techniques (data not shown).

DNA damage in the epithelial cell isolates was evaluated using the sensitive comet assay. We found that DQ12 caused an increase in DNA strand break formation in lung epithelial cells. Interestingly however, no induction was observed when quartz was treated with either PVNO or AL, suggesting that, as for inflammogenic effects, also DNA damage induced by quartz is related to its surface reactivity. Although both coatings have different capacities to inhibit inflammation, our data show that they have more or less similar capacity to reduce quartz-induced acute genotoxic effects in the rat. Also here, a direct antioxidant action of PVNO (57), and thus a possible effect on ROS-induced DNA strand breakage is negligible, as the absolute dose of PVNO is only $22 \mu \mathrm{g}$ (about $0.09 \mathrm{mg} / \mathrm{kg}$ body weight). For 
comparison, a therapeutic, silicosis-inhibiting effect of PVNO is only reported at 7 repeated subcutaneous doses of $40 \mathrm{mg} / \mathrm{kg}$ bodyweight ( 58 ).

No relation was found between DNA damage and isolated cell differentials, suggesting that differences in DNA damage by quartz and coated quartz are not caused by slight changes in the cell populations analysed. The background level of DNA damage in the isolated cells appeared to be relatively high, since at least $30 \%$ of the isolated cells were found to have comet tails. Background levels of DNA strand breakage in isolated type II epithelial cells were shown to be 5 times higher than for alveolar macrophages, which appeared not to be caused by trauma induced during isolation procedures (59). Our own data on viability (trypan blue) of the isolated cells did not show any difference between the treatments as this was always $>95 \%$. This was further confirmed by the observation that the percentage of comet class $\mathrm{V}$ cells (Figure $7 \mathrm{~b}$ ), possibly representing dead cells with extremely fragmented DNA ('clouds') (60), was only about $5 \%$ and did not differ between the treatments. Therefore, our results do not reflect DNA strandbreakage that occurs secondary as a consequence of cytotoxicity (46). Moreover, no relation was found between DNA damage and BALf markers of lung toxicity (LDH, AP or total protein), implicating that routine lung toxicity markers are not associated with DNA damage in epithelial lung cells in the acute phase of quartz exposure. Additionally, the absence of increased levels of alkaline phosphatase, an enzyme specifically present in type II epithelial cells, suggests that no in vivo cytotoxicity is present in this specific target cell. In terms of carcinogenicity these observations are rather important, because initial DNA damage will not evolve into mutagenesis when cytotoxicity prevents the target cells carrying the DNA lesion to proliferate.

Our data on DNA strand breakage are in agreement with earlier observations on the formation of $8-\mathrm{OHdG}$ in the rat lung after quartz exposure (14-16). In these studies, DNA damage was evaluated in total lung tissue homogenates or using immunohistochemical techniques. However, evaluation of the role of DNA damage in particle-induced carcinogenicity is ideally done in cells relevant for neoplastic outcomes $(1,30,61)$. Therefore, in the present study epithelial cells were isolated from the lung prior to quantification of DNA damage. Using this approach we were unable to apply quantitative analysis of 8-OHdG levels as the yield of the cell isolates did not allow analysis using HPLC-ECD. Therefore, we concentrated on detection of DNA strand breakage in single cells, using the comet assay. Considering acute DNA strand breakage as a prerequisite for later mutagenic effects (62), our data also confirm observations on mutagenesis in the HPRT-gene of isolated epithelial cells after sub-chronic quartz exposure (12). They suggested a key role for neutrophils in the mutagenicity observed after quartz exposure. Indeed, numerous in vitro studies demonstrated that neutrophils are capable of inducing several genotoxic effects such as 8-OHdG (17), DNA strand breaks $(63,64)$, SCE's $(65)$, mutations $(66,67)$ and promotion of preneoplastic events (67). In the present study, inhibition of DNA strand breakage by both coatings was paralleled by an overall reduction of neutrophil influx as well as of MPO activity. These observations support the current general consensus on the important role of inflammatory cells in quartzinduced genotoxic effects (30). More specifically, data presented in Figure 8 are in line with data from Driscoll et al (12) and Seiler et al (16), suggesting that there is a threshold for in vivo genotoxicity in the rat. However, pooling all treatments and doing statistics on a single animal level, we were not able to show a clear correlation between neutrophilic inflammation (neutrophil influx, MPO activity) and epithelial DNA damage. This could be due to the relatively high background and rather low variability in absolute levels of DNA stand breakage, but might possibly also relate to the presence of other, inflammatory cellindependent mechanisms of DNA damage. Using an in vitro model of lung epithelial cell lines, allowing to rule out secondary neutrophil effects, we found that quartz-induced 
cytotoxicity (this study) and DNA damage was clearly abrogated when the native quartz particles were coated with either PVNO or AL (28). These observations would fit within our present in vivo data, suggesting that in addition to secondary, inflammatory cell-mediated genotoxicity, direct effects of quartz may have contributed to acute DNA damage induced in epithelial lung isolates (68).

Apart from oxidants generated during in vivo quartz exposure, other factors that determine the overall genotoxic response are the effectiveness of both intra- and extracellular antioxidant defense systems and of DNA repair systems in the target cells exposed to quartz $(28,30)$. Currently, the role of DNA repair mechanisms in genotoxic effects induced by quartz particles is not yet clear, although recent in vitro studies showed that DNA repair was rapidly induced in lung epithelial cells upon exposure to mineral fibers $(69,70)$. The relative high levels of endogenous DNA damage in the isolated epithelial cells could imply possible low DNA repair capacities, which would be consistent with their possible role as target cells for quartz-induced carcinogenicity $(1,59)$. However in addition to DNA repair, the respiratory tract contains a vast number of enzymatic and non-enzymatic antioxidant defense systems, present in both extracellular and intracellular compartments (71). We applied the TEAC assay to evaluate changes in the total extracellular antioxidant capacity of the lung upon quartz exposure, and our data indicate that the increase in antioxidant capacity in the lung was most pronounced upon exposure to native quartz, although this was particularly related with the protein fraction of the BAL-fluid. These observations complement our previous work demonstrating that both message and protein levels of several antioxidant enzymes, such as MnSOD are increased upon exposure to cristalline silica $(72,73)$. However, the fact that DNA strand breakage was found to be induced in the epithelial cell isolates from rats exposed to native quartz, notwithstanding the increased level of antioxidant activity, confirms earlier reports that suggest that in these animals the antioxidant defense systems are overwhelmed by the level of oxidants generated by inflammatory cells $(12,16)$.

In conclusion, in the present study we found that quartz caused DNA strand breakage in isolated epithelial lung cells. This effect was efficiently reduced after surface modification with PVNO or aluminium lactate. Since we demonstrated that simple coating treatments dramatically changes the DNA damaging capacity of quartz, the current data strengthen the body of evidence that quartz is not uniformly carcinogenic across industries where there is quartz exposure (6). Indeed, in collaboration we showed that the reactivity of the DQ12 quartz greatly differed from work place samples, where quartz dust is likely to be mixed with other minerals, such as aluminium salts (48). Moreover, the present data show the feasibility of our in vivo model to evaluate the role of inflammation, antioxidant status, and cytotoxicity in particle-induced DNA damage. Since induction of DNA strand breaks is reported to be closely associated with mutagenesis (62), our data might therefore reflect early molecular events in the initiation stage of quartz-induced tumor formation. However, the mechanism by which quartz causes lung tumours is still by no means clear, and currently we are investigating the significance of the observed acute genotoxic events in later stages of the quartz induced-pathogenesis.

\section{Acknowledgements}

Dr. Klaus Unfried is acknowledged for his great help in the animal instillation experiments. Furthermore, we thank Dr. Peter Hoet (University of Leuven, Belgium) for his helpful suggestions on the isolation of the epithelial lung cells. Kirsten Ledermann is acknowledged for her technical assistance in the BAL analysis. Finally, we acknowledge the ministry of Economic Affairs, and more specifically the ministry of 'Wirtschaft und Mittelstand, Energie und Verkehr NRW' for the financial support enabling this research. CA and AB are postdoc fellows supported by this grant. 


\section{References}

1. Johnson NF, Smith DM, Sebring R, Holland LM. Silica-induced alveolar cell tumors in rats. Am J Ind Med II: 93-107, 1987.

2. Saffiotti U. Lung cancer induction by crystalline silica. Prog Clin Biol Res 374:51-69, 1992 .

3. Muhle H, Kittel B, Emst H, Mohr U, Mermelstein R. Neoplastic lung lesions in rats after chronic exposure to crystalline silica. Scand J Work Emiron Health 21(suppl 2): 27-29, 1995.

4. Driscoll KE. Role of inflammation in the development of rat lung tumors in response to chronic particle exposure. Inhal Toxicol 8(suppl), 139-153, 1996.

5. Borm PJA, Hôhr D, Steinfartz Y. Zeitträger I, Albrecht C. Chronic inflammation and tumor formation in rats after intratracheal instillation of high doses of coal dusts, titanium dioxides and quartz. Inhal Toxicol 12 (suppl 3): 225-231. 2000.

6. IARC Monograph on the Evaluation of the Carcinogenic Risk of Chemicals to Humans, Vol. 68 ; silica, some silicates, coal dust and para-aramid fibrils. IARC Press, Geneva, Switzerland, 1997.

7. Donaldson K, Borm PJA. The quartz hazard: a variable entity. Ann Occup Hyg 42: 287-294, 1998.

8. Weitzman SA, Gordon L.I. Inflammation and cancer: Role of phagocyte-generated oxidants in carcinogenesis. Blood 76: 655-663, 1990.

9. Wiseman H, Halliwell B. Damage to DNA by reactive oxygen and nitrogen species: role in inflammatory disease and progression to cancer. Biochem J 313:17-29, 1996.

10. Borm PJA, Driscoll KE. Particles, inflammation and respiratory tract carcinogenesis. Toxicol Letl 88: 109-13, 1996.

11. Lechner JF. Mauderly J. Sequence of events in lung carcinogenesis: Initiation and promotion, protooncogenes and tumor suppressor genes, and particulates. In: Mohr U. Dungworth DL. Mauderly J, Oberdorster G. (eds.) Toxic and carcinogenic effects of solid particulates in the respiratory tract. ILSI Press, Washington, pp. 235-251, 1994.

12. Driscoll KE, Deyo LC, Carter JM, Howard BW. Hassenbein DG, Bertram TA. Effects of particle exposure and particle-elicited inflammatory cells on mutation in rat alveolar epithelial cells. Carcinogenesis 18: 423-430, 1997

13. Leigh J. Bonin A. Wang H. In vivo genotoxicity of crystalline silica as evidenced by micronuclei in pulmonary alveolar macrophages: Low-dose study. Inhal Toxicol 12(suppl 3): 199-204, 2000.

14. Yamano Y, Kagawa J, Hanaoka T, Takahashi T, Kasai H, Tsugane S, Watanabe S. Oxidative DNA damage induced by silica in vivo. Environ Res 69: 102-107, 1995

15. Nehls P, Seiler F, Rehn B, Greferath R, Bruch J. Formation and persistence of 8-oxoguanine in rat lung cells as an important determinant for tumor formation following particle exposure. Env Health Persp 105(suppl 5): 1291-1296. 1997.

16. Seiler F, Rehn B, Rehn S, Bruch J. Quartz exposure of the rat lung leads to a linear dose response in inflammation but not in oxidative DNA damage and mutagenicity. Am J Respir Cell Mol Biol 24: 492-498, 2001.

17. Knaapen AM, Seiler F, Schilderman PAEL, Nehls P, Bruch J, Schins RPF, Borm PJA. Neutrophils cause oxidative DNA damage in alveolar epithelial cells: Free Rad Biol Med 27: 234-240, 1999.

18. Fubini B. Surface chemistry and quartz hazard. Ann Occup Hyg 42:521-530, 1998.

19. Fubini B, Giamello E, Volante M, Bolis V. Chemical functionalities at the silica surface determining its reactivity when inhaled. Formation and reactivity of surface radicals. Toxicol Ind Health 6:571-598, 1990.

20. Brown GM, Donaldson K, Brown DM. Bronchoalveolar leukocyte response in experimental silicosis: modulation by a soluble aluminum compound. Toxicol Appl Pharmacol 101: 95-105, 1989.

21. Le Bouffant L, Daniel H, Martin JC. The therapeutic action of aluminium compounds on the development of experimental lesions produced by pure quartz or mixed dust. Inhaled Part 4:389-401, 1975.

22. Begin R, Masse S, Sebastien P, Martel M, Geoffroy M, Labbe J. Late aluminum therapy reduces the cellular activities of simple silicosis in the sheep model. J Leukoc Biol 41: 400-406, 1987.

23. Schlipköter HW, Brockhaus, A Die Hemmung der experimentellen Silikose durch subcutane Verabreichung von Polyvinylpyridin-N-oxid. Klin Wschr 39: 1182-1189, 1961.

24. Goldstein B, Rendall RE. The prophylactic use of polyvinylpyridine-N-oxide (PVNO) in baboons exposed to quartz dust. Environ Res 42: 469-481, 1987.

25. Vallyathan V, Shi X, Dalal NS, Irr W, Castranova V. Generation of free radicals from freshly fractured silica dust: potential role in acute silica-induced lung injury. Am Rev Respir Dis 138: 1213-1219, 1988.

26. Duffin R, Gilmour PS, Schins RPF, Clouter A. Guy K, Brown DM, MacNee W, Borm PJA, Donaldson K, Stone V Aluminium lactate treatment of DQ12 quartz inhibits its ability to cause inflammation, chemokine expression and NFkappaB activation. Toxicol Appl Pharmacol 176: 10-17, 2001.

27. Marnett L.J. Oxyradicals and DNA damage. Carcinogenesis 21:361-370, 2000.

28. Schins RPF. Mechanisms of genotoxicity of particles and fibres. Inhal Toxicol 14: 57-78, 2002.

29. Liu X, Keane MJ, Zhong B, Ong T. Wallace WE. Micronucleus formation in V79 cells treated with respirable silica dispersed in medium and in simulated pulmonary surfactant. Mutat Res 361: 89-94, 1996.

30. Greim H, Borm PJA, Schins RPF, Donaldson K, Driscoll KE, Hartwig A, Kuempel E, Oberdörster G, Speit,G. Toxicity of fibers and particles. Report of the workshop held in Munich, Germany, 26-27th October 2000. Inhal Toxicol 13: 101-119.2001.

31. Vallyathan V, Kang JH, Van Dyke K. Dalal NS, Castranova V. Response of alveolar macrophages to in vitro exposure to freshly fractured versus aged silica dust: the ability of prosil 28 , an organosilane material, to coat silica and reduce its biological activity. J Toxicol Emviron Health 33: 303-315. 1991.

32. Vallyathan V. Mega JF, Shi X, Dalal NR. Enhanced generation of free radicals from phagocytes induced by mineral dusts. Am J Respir Cell Mol Biol 6: 404-413, 1992. 
33. Begin R, Masse S, Rola-Pleszezynski M, Martel M, Desmarais Y, Geoffroy M, LeBouffant L, Daniel H, Martin J. Aluminum lactate treatment alters the lung biological activity of quartz. Exp Lung Res 10: 385-399, 1986.

34. Albrecht C, Becker A, Schins RPF, Hohr D, Unfried K, Knaapen AM, Borm PJA. Importance of surface characteristics of DQ12 quartz for acute inflammation. Ann Occup Hyg In press.

35. Gabor S, Anca Z, Zugravu E. In vitro action of quartz on alveolar macrophage lipid peroxides. Arch Environ Health 30: 499-501, 1975

36. Borm PJA, Knaapen AM, Schins RPF, Godschalk RWL, Van Schooten FJ. Neutrophils amplify the formation of DNA adducts by benzolalpyrene in lung target cells. Environ Health Persp 105(suppl 5): 1089-1093, 1997.

37. Driscoll KE, Carter JM, lype PT, Kumari HI., Crosby I.L., Aardema MJ, Isfort RJ, Cody D, Chestnut MH, Burns JL, Le Boeuf RA. Establishment of immortalized alveolar type II cell lines from adult rat lungs. In Vitro Cell Dev Biol 31 : 516-527, 1995

38. Mosmann T. Rapid colorimetric assay for cellular growth and survival: application to proliferation and cytotoxicity assays. J Immunol Meth 65: $517-527,1983$

39. Klebanoff SJ, Waltersdorph AM, Rosen H. Antimicrobial activity of myeloperoxidase. Meth Enzymol 105: $399-403$, 1984.

40. Van den Berg R. Haenen GRMM. Van den Berg H. Bast A. Applicability of an improved Trolox equivalent antioxidant capacity (TEAC) assay for evaluation of antioxidant capacity measurements of mixtures. Food Chem 66: $511-517$. 1999.

41. Richards RJ, Davies N, Atkins 1. Oreffo VI. Isolation, biochemical characterization, and culture of lung type II cells of the rat. Iung 165: 143-158, 1987.

42. Bingle I., Bull TB, Fox B, Guz A, Richards RJ. Tetley TD. Type II pneumocytes in mixed cell culture of human lung: a light and electron microscopic study. Emviron Health Persp 85: 71-80, 1990.

43. I uf $\mathrm{JI}$. Improvements in epoxy resin embedding methods. J Biophys Biochem Cytol 9: 409.414, 1961.

44. Singh NP, McCoy MT. Tice RR, Schneider FI. A simple technique for quantitation of low levels of DNA damage in individual cells. Exp Cell Res 175: 184-191, 1988

45. Olive PL, Banath JP. Durand RE. Heterogeneity in radiation-induced DNA damage and repair in tumor and normal cells measured using the "comet" assay. Radiat Res 122: 86-94, 1990

46. Tice RR, Agurell E. Anderson D. Burlinson B. Hartmann A, Kobayashi H, Miyamac Y, Rojas E. Ryu JC, Sasaki YF. Single cell gel/comet assay: guidelines for in vitro and in vivo genetic toxicology testing. Emviron Mol Mutagen 35 : 206-221, 2000

47. Collins AR, Ma AG, Duthie SJ. The kinetics of repair of oxidative DNA damage (strand breaks and oxidised pyrimidines) in human cells. Mutat Res 336: 69-77, 1995.

48. Clouter A, Brown D, Höh D, Borm P. Donaldson K. Inflammatory effects of respirable quartz collected in workplaces versus standard DQ12 quartz: particle surface correlates. Toxicol Sci 63: 90-98, 2001

49. Fenoglio I. Fubini B. Tiozzo R. Di Renzo F. Effect of micromorphology and surface reactivity of several unusual forms of erystalline silica on the toxicity to a monocyte-macrophage tumor cel line. Inhal Toxicol 12(suppl3): 81-89, 2000.

50. Castranova V. Suppression of the cytotoxicity and fibrogenicity of silica with PVPNO. In: Castranova V. Dala NS. Vallyathan V. (eds) Silica and silica-induced lung diseases. CRC Press, Boca Raton, USA, pp. 293-298, 1995.

51. Nolan RP. Langer AM, Harington JS, Oster G, Selikoff IJ. Quartz hemolysis as related to its surface functionalities. Emviron Res 26: 503.520, 1981 .

52. Schmekel B, Karlsson SE, Linden M. Sundstrom C, Tegner H, Venge P. Myeloperoxidase in human lung lavage. A marker of local neutrophil activity. Inflammation 14:447-454, 1990.

53. Hampton MB, Kettle AJ. Winterbourne CC. Inside the neutrophil phagosome: oxidants, myeloperoxidase, and bacterial killing. Blood 92:3007-3017, 1998.

54. Klebanoff SJ. Myeloperoxidase. Proc Ass Am Phs 111: 383-389, 1999.

55. Hedenborg M. Klockars M. Quartz dust-induced production of reactive oxygen metabolites by human granulocytes. lung 167:23-32, 1989

56. Fubini F. Ilealth effects of silica. In: I egrand AP. (eds.) The surface properties of silicas. John Wiley and Sons, USA. pp. $415-464.1998$

57. Gulumian M. van Wyck A. Free radical scavenging properties of polyvinylpyridine $\mathrm{N}$-oxide: a possible mechanism for its action in pneumoconiosis. M/cd Lav $78: 124-128,1987$

58. Pott F. Dungworth DI., Heinrich U, Muhle H. Kamino K. Germann PG. Roller M. Rippe RM. Mohr U. Lung tumours in rats after intratracheal instillations of dusts. Ann Oec Hog 38(suppl 1): 357-363, 1994

59. Dusinska M, Kovacikova Z, Vallova B, Collins A. Responses of alveolar macrophages and epithelial type II cells to oxidative DNA damage caused by paraquat. Carcinogenesis 19: 809-812, 1998

60. Hartmann A, Speit G. The contribution of cytotoxicity to DNA-effects in the single cell gel test (comet assay). Toxicol Lell 90: 183-188, 1997

61. Albrecht C, Adolf B, Weishaupt C, Hohr D, Zeittrăger I, Friemann J, Borm PJA. Clara-cell hyperplasia after quartz and coul-dust instillation in rat lung. Inhal Toxicol 13: 191-205, 2001

62. Phillips JW. Morgan WF. DNA double-strand breaks in mutagenesis. Emvinon Mol Ifutagen 22: 214-217. 1993

63. Shacter E, Beecham EJ, Covey JM. Kohn KW. Potter M. Activated neutrophils induce prolonged DNA damage in neighboring cells. Cancinogenesis 9: 2297-2304, 1988

64. Schraufstäter I, Hyslop PA. Jackson JH. Cochrane CG. Oxidant-induced DNA damage of target cells. J Clin Imest 82 1040-1050, 1988.

65. Weitberg AB. Weitzman SA. Destrempes M. Lan SA. Stossel TP. Stimulated human phagocytes produce cytogenetic changes in cultured mammalian cells. Nive Eng $J$ Med 308: 26-29, 1983 
66. Akman SA, Sander F, Garbutt K. In vivo mutagenesis of the reporter plasmid pSP189 induced by exposure of host Ad293 cells to activated polymorphonuclear leukocytes. Cancinogenesis 17:2137-2141, 1996.

67. Weitzman SA, Weitberg AB, Clark EP, Stossel TP. Phagocytes as carcinogens: malignant transformation produced by human neutrophils. Science 227: 1231-1233, 1985.

68. Saffiotti U, Daniel LN, MaoY, Shi X. Williams AO, Kaighn ME. Mechanisms of carcinogenesis by crystalline silica in relation to oxygen radicals. Environ Health Perspect 102 (suppl 10): 159-163, 1994.

69. Kim HN, Morimoto Y, Tsuda T, Ootsuyama Y, Hirohashi M, Hirano T, Tanaka I, Lim Y, Yun IG, Kasai H. Changes in DNA 8-hydroxyguanine levels, 8-hydroxyguanine repair activity, and hOGGI and hMTHI mRNA expression in human lung alveolar epithelial cells induced by crocidolite asbestos. Carcinogenesis 22: 265-269, 2001.

70. Kamp DW, Srinivasan M, Weitzman SA. Cigarette smoke and asbestos activate poly-ADP-ribose polymerase in alveolar epithelial cells. J Imest Med 49: 68-76, 2001.

71. Janssen YMW, Van Houten B, Borm PJA, Mossman BT. Cell and tissue responses to oxidative damage. Lab /mvest 69: 261-274, 1993.

72. Janssen YMW, Marsh JP, Absher MP, Hemenway D, Vacek PM, Leslie KO, Borm PJA, Mossman BT. Expression of antioxidant enzymes in rat lungs after inhalation of asbestos or silica. $J$ Biol Chem 267: 10652-10630, 1992.

73. Driscoll KE, Carter JM, Borm PJA. Antioxidant defense mechanisms and the toxicity of fibrous and nonfibrous particles. Inhal Toxicol 14: 101-118, 2002. 


\section{Chapter 8}

\section{Summary and general discussion}

Chronic exposure to particles such as particulate air pollution (particulate matter, PM) and crystalline silica (e.g. quartz) has been associated with increased lung cancer rates in both rats and humans [1-5]. Nevertheless, the mechanisms involved in carcinogenesis after particle exposure have only partly been elucidated. Carcinogenesis is a complicated multistep process and specifically in the initiation stage, genotoxic events are thought to play a crucial role. In vitro studies indicated that the genotoxic properties of particles may depend on characteristics such as size, shape, chemical composition, surface reactivity, crystallinity, hydrophobicity, and solubility [6]. In rats however, carcinogenicity after high dose exposures appears to be independent from any inherent genotoxic activity of the particles, and is considered to be mainly related to genotoxic processes and increased epithelial cell proliferation caused by (chronic) inflammation and inflammatory phagocyte-derived ROS [7-9]. These observations imply that studies aiming to investigate the mechanisms involved in particle-induced genotoxicity need an approach which allows to discriminate between primary (particleinduced) and secondary (inflammatory phagocyte-induced) genotoxic processes. Since the generation of ROS is thought to be a crucial event in both processes, the present thesis has aimed to investigate ROS-induced DNA damage in respiratory tract epithelial target cells after particle exposure. In the first part of the thesis (Chapters 2-4), we specifically focussed on mechanisms involved in primary genotoxicity, whereas in Chapters 5-7 secondary genotoxic processes are described. In these final chapters special emphasis was put on the role of neutrophils, since these cells are hypothesised to be potent mediators of secondary genotoxicity in particle-exposed rats [10]. Two different types of particles were used, particulate matter (PM) and quartz, which are both known to be associated with an array of pulmonary diseases in humans (Chapter 1.5), including an increased risk of lung cancer development.

\section{Findings on primary genotoxicity}

In the first part of this thesis (Chapters 2-4) possible mechanisms involved in ROS-mediated primary genotoxic effects of PM and quartz are discussed. Major focus was on the hydroxyl radical, since it is the most reactive ROS towards DNA [11]. In the past, numerous studies have provided indirect or circumstantial evidence that ${ }^{\circ} \mathrm{OH}$ could play a crucial role in both quartz- and PM-induced genotoxicity [12-18]. In this thesis electron spin resonance with a specific spin-trap (DMPO) was applied to directly demonstrate that both PM and DQ12quartz are able to generate ${ }^{\circ} \mathrm{OH}$ in aqueous solutions. Importantly, ${ }^{\circ} \mathrm{OH}$ formation by both particles was facilitated by the addition of $\mathrm{H}_{2} \mathrm{O}_{2}$, which points to an involvement of Fentonlike mechanisms, indicating a role of transition metals. Indeed, $\mathrm{OH}$ formation by $\mathrm{PM}$ was inhibited by deferoxamine, suggesting an important role of iron [19]. On the other hand, the "OH-generating capacity of DQ12-quartz is likely to be explained by the action of reactive functionalities at the particle surface $[20,21]$. This was confirmed by experiments showing that ESR-detected ${ }^{\circ} \mathrm{OH}$ formation by DQ12 was reduced after treatment of the particle surface 
with either aluminium lactate or PVNO [22,23]. Since ${ }^{\circ} \mathrm{OH}$ is strongly implicated in DNA damage, the ${ }^{\circ} \mathrm{OH}$-generating properties of both PM and quartz provide a possible common mechanism involved in their primary genotoxic action. Analysis of DNA strand breakage and 8-OHdG induction (Figure 1) were used as (semi-)specific tools to detect ${ }^{\circ} \mathrm{OH}$-mediated DNA damage $[24,25]$. Using naked DNA we demonstrated that the ability of PM to induce DNA strand breakage and $8-\mathrm{OHdG}$ was indeed closely related to its ${ }^{\circ} \mathrm{OH}$-generating properties (Chapters $2 \& 3$ ). Similar results were also found for quartz, although not presented in this thesis (unpublished data) [26].

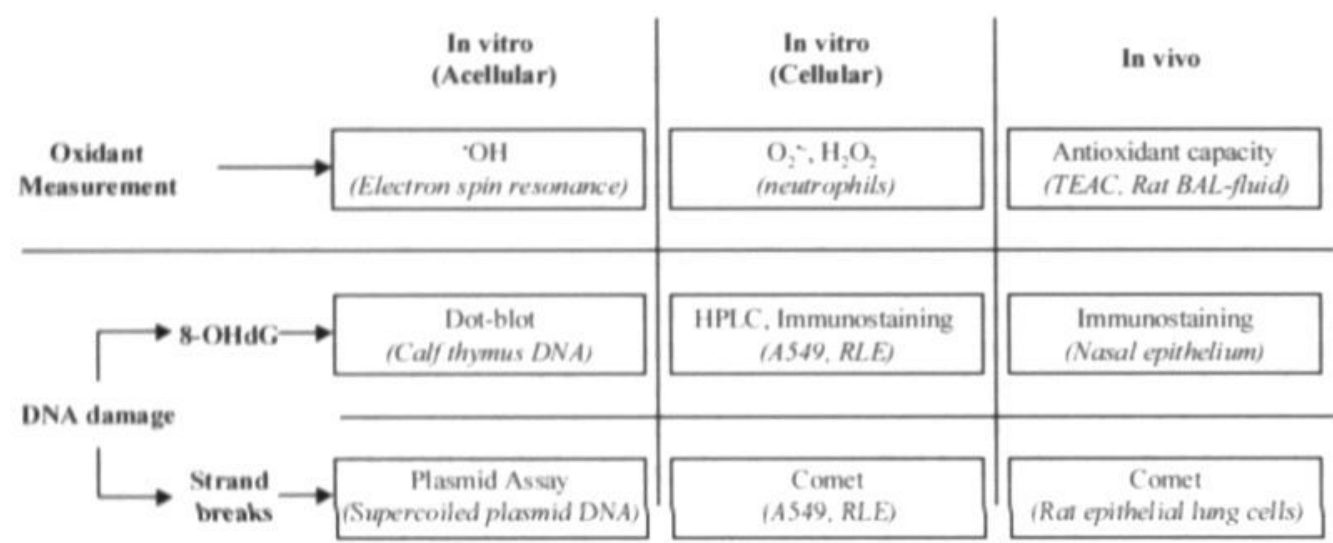

Figure 1. Schematic overview of the various methods and models used in the present thesis to investigate the role of ROS in particle-induced DNA damage.

To extend our observations beyond naked DNA, PM and DQ12-quartz were also tested in pulmonary target cell lines. Therefore, alveolar epithelial cells from human (A549), or rat (RLE) origin were used, since these cells are considered to be a specific target for particleinduced hyperplasia and carcinogenicity $[4,27,28]$. We demonstrated that DQ12-quartz as well as PM cause primary DNA damage (8-OHdG and DNA strand breakage) in both RLE and A549 cells. In line with experiments on naked DNA, our data suggest that also target cellular DNA damage induced by PM or quartz could be at least partly attributed to the generation of ${ }^{\circ} \mathrm{OH}$. However, it is important to realise that PM and quartz are totally different types of particles and that dissimilar mechanisms may underlie ${ }^{\circ} \mathrm{OH}$-mediated DNA damage in target cells. Whereas DQ12-quartz is a more or less homogeneous particulate compound, comprised of about $90 \%$ crystalline silica (the rest being amorphous silica), PM is chemically highly heterogeneous (Chapter 1.5). The most important difference however, is the fact that in contrast to DQ12, a large part of PM is soluble. Indeed, although the insoluble particle core of PM was suggested to contribute to cellular DNA damage (Chapter 4), we demonstrated that the ${ }^{\circ} \mathrm{OH}-$ generating capacity of PM and associated DNA damage was most likely due to factors present in the soluble fraction, probably iron (Chapters 3 \& 4). Under normal conditions iron is carefully sequestered in a target cell. However, during iron exposure the cellular iron-binding capacity may be overwhelmed, which could facilitate Fenton-mediated "OH formation and thus the induction of DNA damage $[29,30]$. For quartz on the other hand, "OH generation and related cellular DNA damage is thought to be mainly associated with surface properties of the insoluble particles [6]. Due to its extremely high reactivity, $\mathrm{OH}$ will only react with DNA when it is generated in direct proximity [31]. Considering a role of ${ }^{\circ} \mathrm{OH}$ generated at the quartz surface, this implicates that insoluble quartz particles should migrate 
into the nucleus after uptake by target cells. Preliminary studies performed in our lab indicate that A549 as well as RLE cells are indeed able to ingest particles [32]. However, although quartz particles have been found in the nuclei of alveolar epithelial cells after prolonged exposure (26 Days) [33], we did not observe nuclear translocation after short-term incubations ( $2-4 \mathrm{~h})$, as used in our in vitro studies (unpublished observations). Nevertheless, evaluation of nuclear particle migration and associated site-specific induction of ${ }^{\circ} \mathrm{OH}$ mediated DNA damage remains a challenge for future research. In addition, to assess the role of particle uptake more generally, and to further elucidate (geno)toxicokinetics of insoluble particles in target cells, it would be helpful to evaluate DNA damage on a single cell level and to correlate individual cellular particle burdens with DNA damage.

Our acellular experiments indicated that the presence of $\mathrm{H}_{2} \mathrm{O}_{2}$ was more or less a prerequisite for PM and quartz to generate ${ }^{\circ} \mathrm{OH}$. In contrast, in A549 and RLE cells, ${ }^{\circ} \mathrm{OH}$ mediated DNA damage by both particles was observed in the absence of extracellularly added $\mathrm{H}_{2} \mathrm{O}_{2}$. However, observations on endogenous $\mathrm{H}_{2} \mathrm{O}_{2}$ production in alveolar type II cells [34], suggest that $\mathrm{H}_{2} \mathrm{O}_{2}$ might still be involved in particle-induced cellular DNA damage. This is further supported by studies showing the induction of $\mathrm{H}_{2} \mathrm{O}_{2}$ generation by rat type II cells upon exposure to quartz [35]. Moreover, others demonstrated that PM-induced DNA strand breakage in lung target cells could be inhibited by the addition of the $\mathrm{H}_{2} \mathrm{O}_{2}$ scavenger catalase [36]. In considering a role of $\mathrm{H}_{2} \mathrm{O}_{2}$ it should be noted that it is freely diffusable through the cell and is thought to induce DNA damage via intranuclear ${ }^{\circ} \mathrm{OH}$ formation upon reaction with DNA-bound transition metals [19,30]. As such, it could be hypothesised that particle-induced endogenous $\mathrm{H}_{2} \mathrm{O}_{2}$ generation provides a possible mechanism for ${ }^{\circ} \mathrm{OH}$-mediated DNA damage in the absence of a direct interaction between particles and nuclear DNA. However, the significance of such a mechanism remains to be evaluated.

\section{Findings on secondary genotoxicity}

Phagocyte-derived ROS have been suggested to be responsible for the secondary genotoxic processes as observed in particle-exposed rats [7,37]. Among phagocytes, neutrophils have the largest capacity to generate ROS [38,39]. Moreover, rat BAL-derived neutrophils were shown to be more potent to induce mutations than alveolar macrophages [37]. Therefore, it is likely to suggest that the neutrophil represents the major effector cell in secondary genotoxicity of particles in the rat. However, the ability and mechanism of neutrophils to induce oxidative DNA damage specifically in pulmonary epithelial target cells for particleinduced carcinomas was not yet investigated. In Chapters 5 and 6 we demonstrated using a coincubation model that activated neutrophils caused the induction of $8-\mathrm{OHdG}$ and strand breaks in DNA from rat lung type II epithelial cells (RLE) in vitro. Interestingly, the observations on 8-OHdG support in vivo studies on quartz-exposed rats, which already provided circumstantial evidence for neutrophil-induced $8-\mathrm{OHdG}$ formation in the lung $[17,18]$. In addition, the data on DNA strand breakage are complementary to our own in vivo observations in the rat, where epithelial DNA strand breakage was associated with neutrophil presence and activity (Chapter 7).

The data presented in Chapter 6 indicate that neutrophil-induced DNA strand break formation in neighbouring cells is likely to involve $\mathrm{H}_{2} \mathrm{O}_{2}$, which is in line with earlier observations on non-pulmonary target cells [40,41]. Furthermore, by the identification of specific DNA base modifications, such as $8-\mathrm{OHdG}$ (Chapter 5), and by the use of specific scavengers we and others demonstrated that a major part of DNA damage induced by neutrophils is mediated by the intracellular generation of ${ }^{\circ} \mathrm{OH}$, which parallels observations on primary DNA damage by quartz or PM (Chapter 2-4) $[40,42,43]$. Interestingly, data from Chapter 6 also suggest that a close contact between target cells and activated neutrophils is a 
prerequisite for genotoxicity to occur, because $\mathrm{H}_{2} \mathrm{O}_{2}$ might otherwise be prematurely consumed by for instance myeloperoxidase. In Chapter 6 we also evaluated the association between nasal inflammation (neutrophil numbers in nasal lavage) and the induction of 8OHdG in nasal epithelial cells from 80 children selected from a larger cohort sampled in Nordrheinland-Westfalen (Germany). However, no clear relationship between the presence of neutrophils and epithelial DNA damage was observed (Chapter 6).

In Chapter 7 we demonstrated that intratracheal instillation of quartz causes acute DNA strand breakage in epithelial lung cells of the rat. Rather than evaluating whole lung homogenates, we isolated epithelial cells in order to study DNA damage in specific target cells for particle-induced pulmonary carcinogenesis. We found that DNA strand breakage was reduced by treatment of the quartz particle surface prior to instillation, indicating a crucial role of the reactive functionalities at the silica surface. Since simple coating procedures (aluminium lactate or PVNO) inhibited quartz-induced genotoxicity, these data further strengthen the body of evidence that the quartz hazard is a variable entity [44], and that quartz is not uniformly carcinogenic across industries where there is quartz exposure [5]. Most interestingly, the inhibition of DNA damage by surface treatment was paralleled by a reduction of inflammatory cell influx. Since neutrophils, and to a lesser extent macrophages, are potent generators of ROS, the data suggest the contribution of a neutrophil-mediated process of secondary DNA damage in the quartz-exposed rat. More specifically, although observed from single dose exposures to either native or surface-modified quartz, we demonstrated the existence of a sort of threshold for neutrophil-mediated DNA strand breaks in the rat lung, which corresponds to observations from others on 8-OHdG and HPRTmutations [10,18,37].

Using in vitro incubations we demonstrated that quartz directly activates neutrophils to generate ROS (Chapter 7). However it needs to be emphasised that this process might not necessarily relate to ROS generation in the lung. For instance, reference non-toxic particles such as carbon black and titanium dioxide are often unable to elicit a direct oxidative burst in inflammatory cells in vitro $[45,46]$, whereas instillation of these particles in the rat induces an inflammatory reaction and subsequent ROS-mediated mutagenesis [37,47]. This would suggest that phagocyte-mediated ROS release and related DNA damage in the lung after particle exposure is not only a matter of particle-phagocyte interactions, but is a consequence of a co-operative action of particles, inflammatory phagocytes, pulmonary epithelial target cells and cytokines. However, the presence of particles such as quartz and PM could still impact on the ultimate genotoxic effect of the inflammatory cell-generated ROS, since a combination of $\mathrm{H}_{2} \mathrm{O}_{2}$ and such particles was shown to result in the formation of the deleterious ${ }^{\circ} \mathrm{OH}$ (Chapters 2-4).

\section{Some perspectives on particle genotoxicity}

The studies described in the first part of this thesis demonstrate that PM and DQ12-quartz are able to induce primary, inflammation-independent DNA damage in epithelial lung target cells in vitro. As such, these data indicate that PM as well as DQ12-quartz should be considered as genotoxic. It remains however to be established whether these mechanisms of primary genotoxicity contribute to genotoxic processes after in vivo exposure to quartz or PM. Furthermore, the composition of both types of particles may vary with their origin, and it should therefore be realised that their inherent capacity to induce DNA damage may vary depending on their ultimate chemical and physical characteristics. This also implies that one should be cautious in making generalisations about the mechanisms involved in the genotoxic action of PM or quartz. 
Studies described in the second part show that neutrophils induce oxidative DNA damage (8-OHdG, strand breakage) in alveolar epithelial cells in vitro. Moreover, the data support our own in vivo observations in rats exposed to quartz (Chapter 7), where it seems that at least a part of the DNA damage as observed in isolated epithelial cells can be attributed to a secondary genotoxic effect of neutrophils. In general, these data contribute to the consensus on a crucial role of inflammatory phagocytes in particle-induced genotoxicity in the rat [9]. Considering DNA damage $(8-\mathrm{OHdG}$, strand breakage) as a premutagenic event, our in vitro and in vivo observations are also complementary to studies which suggest that particle-mediated mutagenicity (HPRT, p53) in the rat lung is driven by neutrophil-derived ROS [18,37].

In this thesis the role of oxidants in particle-induced DNA damage was investigated using an approach which included a whole array of tests ranging from in vitro acellular incubations to in vivo studies in rats and humans (Figure 1). This allowed us to separately investigate mechanisms involved in either primary or secondary particle-induced DNA damage. The acellular assays as described in the first part represent valuable tools for an efficient and fast screening of the ROS-generating capacity and associated ability of particles to induce damage in naked DNA. However, it should be kept in mind that the effects as seen in these assays, where DNA is in direct contact with high particle concentrations, are unlikely to occur in cellular DNA. As such, for purposes of mechanistical research, acellular assays are only useful to supplement findings on particle-induced genotoxicity in cellular assays. Cellular genotoxicity studies, attempting to contribute to the elucidation of mechanisms involved in particle-induced carcinogenicity should ideally be performed by using target cells relevant for neoplastic outcomes [9]. Also in vivo studies should focus on specific target cells instead of evaluating DNA damage in whole lung homogenates or inflammatory cells obtained by BAL. We showed that isolation of epithelial cells, as described in Chapter 7 provides an opportunity to tackle particle-induced in vivo genotoxicity in a 'multiple-marker' approach, since the contribution of various factors, including inflammatory cell influx, antioxidant status and cytotoxicity can be evaluated within a single animal. Moreover, when applied in studies evaluating DNA damage at different time points and multiple doses, in combination with a DNA repair assessment, this model could be of great value to provide more insight in kinetics and persistence of particle-induced DNA damage in the rat.

Although data from Chapter 7, together with the in vitro observations from Chapters 5 \& 6, suggest the involvement of neutrophils in quartz-induced DNA damage in the rat lung, recent studies indicate that also other processes should be considered [18,48]. An alternative process would be a primary in vivo genotoxic effect of quartz, as already indicated by our in vitro studies (Chapter 4 ). However, it must be realised that the rat is not completely valid to investigate in vivo primary DNA damage, since particle exposure will always be accompanied by a certain level of neutrophil influx. As a consequence, the rat model as applied in Chapter 7 can only be used to indirectly assess the contribution of primary genotoxicity, for instance by comparing epithelial DNA damage induced by primary genotoxic particles with effects of non-genotoxic particles (e.g. $\mathrm{TiO}_{2}$ ) or compounds (e.g. endotoxins), administered at doses eliciting an equal neutrophil influx. However, the best and most direct method to evaluate in vivo primary genotoxicity in the rat would be to inhibit the influx of neutrophils after particle exposure, what could be achieved by depletion of the rat lung from alveolar macrophages [49].

\section{Implications for risk assessment}

The major question that remains to be answered, is whether the mechanisms of particleinduced DNA damage as discussed in this thesis are relevant to humans. Considering primary genotoxicity of particles, it can be assumed that humans are at a certain risk at any exposure. 
In other words, for non-inflammatory doses the exposure-response relationship for primary genotoxicity is expected to be more or less linear. Secondary genotoxicity on the other hand, will only occur at particle doses that elicit a significant inflammatory cell influx with associated ROS generation, at levels that overwhelm the pulmonary antioxidant- and DNA repair capacity. As such, a dose-response relationship for particle-related secondary genotoxicity will have a threshold, as illustrated in Chapter 7. However, this concept of secondary genotoxicity is based on rat studies using particles mostly at overload doses. Since genotoxicity and carcinogenicity observed in this model are obviously high dose effects, the extrapolation to humans, generally exposed to much lower particle concentrations and having a less extensive inflammatory response, is a major subject for ongoing debate [9].

Another point of discussion could be the specific role of the neutrophil. Although shown beyond doubt in vitro, the genotoxic effect of neutrophils on respiratory tract epithelial cells in vivo is only indirectly demonstrated, and largely based on observations in particleexposed rats. Since the nasal lavage fluid from healthy persons mainly contains neutrophils ( $~ 80 \%$ of total cells), this led us to suggest that the nose would be an appropriate 'model' to evaluate neutrophil-induced DNA damage in the human respiratory tract. However, to our own surprise we could not find a clear relation between neutrophil numbers present in nasal lavage and 8-OHdG formation in nasal epithelial cells (Chapter 6). Although one could think of various explanations for this discrepancy, the data indicate that only the presence of neutrophils is not necessarily linked to epithelial DNA damage. Therefore, models are needed that allow to study the causal relationship between neutrophils and pulmonary genotoxicity in vivo, and to assess the importance of other possible contributing factors, such as the presence of alveolar macrophages, particles, cytokines or growth factors.

Secondary to a discussion on the causal relationship between neutrophils and pulmonary genotoxicity in general, it should be realised that, in contrast to the rat, the inflammatory response in humans chronically exposed to crystalline silica is mainly characterised by an influx of macrophages and lymphocytes, whereas only minimal increases in neutrophils are seen [5]. Together with the fact that we could not find a relation between neutrophils and nasal epithelial DNA damage, these observations raise the question whether neutrophils play a significant role in secondary genotoxicity of chronically particle-exposed humans at all. On the other hand, recent data on humans acutely exposed to PM suggest that neutrophils might play a role in the more acute phase of particle exposure [50]. In conclusion, together with these observations on humans, the data presented in this thesis demonstrate that the relation between particles, neutrophils and respiratory tract genotoxicity is a complicated one, and that a definite mechanism of secondary genotoxic processes during particle exposure still remains to be determined. Therefore, the studies as described in Chapters 5-7 should be considered as a starting point to further elucidate the significance and role of neutrophils in particle-induced genotoxicity in vivo.

In the present thesis mechanisms involved in the induction of primary and secondary particle-induced DNA damage were evaluated. However, it should be emphasised that this approach does not provide any insight into more downstream processes of carcinogenesis associated with chronic particle exposure. Especially for purposes of risk assessment, it must be realised that genotoxicity only relates to DNA reactivity, which means that it is essentially not the same as carcinogenicity. Therefore, whereas the data presented in this thesis indicate that particles (PM, quartz) as well as inflammatory phagocytes (neutrophils) induce ROSmediated DNA damage in target cells relevant for tumourigenic outcomes, the implication of these processes for particle-related lung carcinogenesis requires much further study. 


\section{References}

1. Dockery DW, Pope CA III, Xu X, Spengler JD, Ware JH, Fay ME, Ferris BG, Speizer FE: An association between air pollution and mortality in six U.S. cities. New Eng J Medicine 329: 1753-1759, 1993.

2. Cohen AJ, Pope CA III: Lung cancer and air pollution. Environ Health Perspect 103 (suppl 8): 219-224, 1995

3. Pope CA III, Burnett RT, Thun MJ, Calle EE, Krewski D, Ito K. Thurston GD. Lung cancer, cardiopulmonary mortality, and long-term exposure to fine particulate air pollution. JAMA 287: 1132-1141, 2002.

4. Nikula KJ. Snipes MB, Barr EB, Griffith WC, Henderson RF, Mauderly J. Comparative pulmonary toxicities and carcinogenicities of chronically inhaled diesel exhaust and carbon black in F344 rats. Fundam Appl Taxicol 25: 80-94, 1995.

5. LARC. IARC Monograph on the Evaluation of the Carcinogenic Risk of Chemicals to Humans, Vol. 68: silica, some silicates, coal dust and para-aramid fibrils. IARC Press, Geneva, Switzerland, 1997

6. Schins RPF. Mechanisms of genotoxicity of particles and fibres. Inhal Toxicol 14: 57-78, 2002.

7. Driscoll KE. Role of inflammation in the development of rat lung tumors in response to chronic particle exposure, Inhal Toxicol 8 (suppl): 139-153, 1996.

8. Borm PJA, Hōhr D, Steinfartz Y. Zeittăger I, Albrecht C. Chronic inflammation and tumor formation in rats after intratracheal instillation of high doses of coal dusts, titanium dioxides and quartz. Inhal Toxicol 12 (suppl 3), 225-231. 2000.

9. Greim H, Borm PJA, Schins RPF, Donaldson K, Driscoll KE, Hartwig A, Kuempel E, Oberdorster G, Speit G. Toxicity of fibers and particles. Report of the workshop held in Munich, Germany, 26-27th October 2000. Inhal Toxicol 13, 101. 119,2001 .

10. Borm PJA. Driscoll KE. Particles, inflammation and respiratory tract carcinogenesis. Toxicol Lett 88: 109-113, 1996.

11. Pryor WA. Why is the hydroxyl radical the only radical that commonly adds to DNA? Hypothesis: it has a rare combination of high electrophilicity, high thermochemical reactivity, and a mode of production that can occur near DNA. Free Radic Biol Med 4: 219-223, 1988.

12. Saffiotti U, Daniel LN, MaoY, Shi X, Williams AO, Kaighn ME. Mechanisms of carcinogenesis by crystalline silica in relation to oxygen radicals. Environ Health Perspect 102 (suppl 10): 159-163, 1994

13. Shi X, Mao Y, Daniel LN, Saffiotti U, Dalal NS, Vallyathan V. Silica radical-induced DNA damage and lipid peroxidation. Environ Health Perspect 102 (suppl 10): 149-154, 1994.

14. Schapira RM, Ghio AJ, Effros GM, Morrisey J, Almagro UA, Dawson CA, Hacker AD. Hydroxyl radical production and lung injury in the rat following silica or titanium dioxide instillation in vivo. Am J Respir Cell Mol Biol 12:220. 226, 1995.

15. Yamano Y, Kagawa J, Hanaoka T, Takahashi T, Kasai H, Tsugane S, Watanabe S. Oxidative DNA damage induced by silica in vivo. Environ Res 69: 102-107, 1995.

16. Donaldson K, Brown DM, Mitchell C, Dineva M, Beswick PH, Gilmour P, MacNee W. Free radical activity of PM 10 : iron-mediated generation of hydroxyl radicals. Environ Health Perspect 105 (suppl 5): 1285-1289, 1997.

17. Nehls P, Seiler F, Rehn B, Greferath R, Bruch J. Formation and persistence of 8-oxoguanine in rat lung cells as an important determinant for tumor formation following particle exposure. Env Health Persp 105(suppl 5): 1291-1296. 1997.

18. Seiler F, Rehn B, Rehn S, Bruch J. Quartz exposure of the rat lung leads to a linear dose response in inflammation but not in oxidative DNA damage and mutagenicity. Am J Respir Cell Mol Biol 24:492-498, 2001

19. Henle ES, Linn S. Formation, prevention and repair of DNA damage by iron/hydrogen peroxide. $J$ Biol Chem 272 : 19095-19098, 1997.

20. Fubini B, Giamello E, Volante M, Bolis V. Chemical functionalities at the silica surface determining its reactivity when inhaled. Formation and reactivity of surface radicals. Toxicol Ind Health 6:571-598, 1990.

21. Fubini B. Surface chemistry and quartz hazard. Ann Occup Hyg 42:521-530, 1998.

22. Duffin R, Gilmour PS, Schins RPF, Clouter A, Guy K, Brown DM, MacNee W, Borm PJA, Donaldson K, Stone V. Aluminium lactate treatment of DQ12 quartz inhibits its ability to cause inflammation, chemokine expression and NF. kappaB activation. Toxicol Appl Pharmacol 176: 10-17, 2001.

23. Schins RPF, Duffin R, Höhr D, Knaapen AM, Shi T, Weishaupt C, Stone V, Donaldson K. Borm PJA. Oxidative DNA damage in human lung epithelial cells by surface modified DQ12 quartz particles: role of radical formation and particle uptake. Submitted.

24. Kasai H. Nishimura S. Hydroxylation of deoxyguanosine at the C-8 position by ascorbic acid and other reducing agents. Nucl Acids Res 4, 2137-2145, 1984.

25. Lloyd DR, Carmichael PL, Phillips DH. Comparison of the formation of 8-hydroxy-2'-deoxyguanosine and single- and double-strand breaks in DNA mediated by Fenton reactions. Chem Res Toxicol 11: 420-427, 1998.

26. Daniel LN, Mao Y, Saffiotti U. Oxidative DNA damage by crystalline silica. Free Radic Biol Med 14:463-472, 1993.

27. Johnson NF, Smith DM, Sebring R, Holland LM. Silica-induced alveolar cell tumors in rats. Am J Ind Med 11: 93-107, 1987.

28. Albrecht C, Adolf B. Weishaupt C, Höhr D, Zeittrăger I, Friemann J, Borm PJA. Clara-cell hyperplasia after quart/ and coal-dust instillation in rat lung. Inhal Toxicol 13: 191-205, 2001.

29. Zastawny TH. Altman SA. Randers-Eichhorn L. Madurawe R, Lumpkin JA. Dizdaroglu M, Rao G. DNA base modifications and membrane damage in cultured mammalian cells treated with iron ions. Free Radic Biol Med 18 1013-1022, 1995.

30. Rodriquez H, Holmquist GP. D'Agostino R Jr, Keller J, Akman SA. Metal-ion specific hydrogen peroxide-induced DNA damage is more sequence specific than metal specific. Cancer Res 57: 2394-2403. 1997. 
31. Halliwell B, Gutteridge JMC. Free radicals in biology and medicine. Clarendon Press, Oxford, 1985.

32. Hôt D, Schins RPF, Weishaupt C, Borm PJA. Uptake of native and surface-modified silica in epithelial cells and macrophages. Ann Occup Hyg, in press.

33. Daniel LN, Mao Y, Williams AO, Saffiotti U. Direct interaction between crystalline silica and DNA - a proposed model for silica carcinogenesis. Scand J Work Environ Health 21 (suppl 2): 22-26, 1995.

34. Van Klaveren RJ, Roelant C, Boogaerts M, Demedts M, Nemery B. Involvement of an NAD(P)H oxidase-like enzyme in superoxide anion and hydrogen peroxide generation by rat type II cells. Thorax 52: 465-471, 1997.

35. Driscoll KE, Howard BW, Carter JM, Janssen YM, Mossman BT, Isfort RJ. Mitochondrial-derived oxidants and quart activation of chemokine gene expression. Adv Exp Med Biol 500; 489-496, 2001.

36. Dellinger B, Pryor WA, Cueto R, Squadrito GL. Hegde V. Deutsch WA. Role of free radicals in the toxicity of airborne fine particulate matter. Chem Res Toxicol 14: 1371-1377, 2001.

37. Driscoll KE, Deyo L.C, Carter JM, Howard BW, Hassenbein DG, Bertram TA. Effects of particle exposure and particle-elicited inflammatory cells on mutation in rat alveolar epithelial cells. Carcinogenesis 18: 423-430, 1997.

38. Kamp DW, Dunn MM, Sbalchiero JS, Knap AM, Wietzman SA. Contrasting effects of alveolar macrophages and neutrophils on asbestos-induced pulmonary epithelial cell injury. Am J Physiol 266, L.84-L.91. 1994.

39. Haugen TS, Skjonsberg OH, Kahler H, Lyberg T. Production of oxidants in alveolar macrophages and blood leukocytes. Eur Resp J 14: 1100-1105, 1999

40. Schraufstatter I, Hyslop PA, Jackson JH, Cochrane CG. Oxidant-induced DNA damage of target cells. J Clin Invest 82: 1040-1050, 1988 .

41. Shacter E, Beecham EJ, Covey JM, Kohn WW. Activated neutrophils induce prolonged DNA damage in neighboring cells. Carcinogenesis 9: 2297-2304, 1988.

42. Jackson JH, Gajewski E, Schraufstatter IU, Hyslop PA, Fuciarelli AF, Cochrane CG, Dizdaroglu M. Damage to bases in DNA induced by stimulated human neutrophils. J Clin Imvest 84: 1644-1649, 1989.

43. Dizdaroglu M, Olinski R, Doroshow HH, Akman SA. Modification of DNA bases in chromatin of intact target human cells by activated human polymorphonuclear leukocytes. Cancer Res 53: 1269-1272, 1993.

44. Donaldson K. Borm PJA. The quartz hazard: a variable entity. Ann Occup Hyg 42: 287-294, 1998.

45. Nyberg P, Klockars M. Measurement of reactive oxygen metabolites produced by human monocyle-derived macrophages exposed to mineral dusts. Int J Exp Pathol 71:537-544, 1990.

46. Prahalad AK, Soukup JM, Inmon J, Willis R, Ghio NJ, Becker S, Gallagher JE. Ambient air particles: effects on cellular oxidant radical generation in relation to particulate elemental chemistry. Toxicol Appl Pharmacol 158: 81-91, 1999.

47. Driscoll KE, Carter JM. Howard BW, Hassenbein DG, Pepelko W, Baggs, RB, Oberdőrster G. Pulmonary inflammatory, chemokine, and mutagenic responses in rats after subchronic inhalation of carbon black. Toxicol Appl Pharmacol. 136: 372-80, 1996a.

48. Johnston CJ, Driscoll KE, Finkelstein JN, Baggs R, O'Reilly MA, Carter J, Gelein R, Oberdörster G. Pulmonary chemokine and mutagenic responses in rats after subchronic inhalation of amorphous and crystalline silica. Toxicol Sci 56: 405-413, 2000.

49. Lentsch AB, Czermak BJ, Bless NM, Van Rooijen N. Ward PA. Essential role of alveolar macrophages in intrapulmonary activation of NF-KB. Am J Respir Cell Mol Biol 20: 692-698, 1999.

50. Ghio AJ, Devlin RB. Inflammatory lung injury after bronchial instillation of air pollution particles. Am J Respir Crit Care Med 164: 704-708, 2001. 


\section{Samenvatting}

Chronische inademing van deeltjes zoals fijn stof (Engels: particulate air pollution, ofwel particulate matter, PM) en kristallijn silica (kwarts) kan longkanker veroorzaken in zowel ratten als mensen. Echter, de mechanismen die een rol spelen in de vorming van een longtumor na blootstelling aan stofdeeltjes zijn nog niet opgehelderd. In het algemeen geldt dat genotoxische gebeurtenissen een belangrijke rol spelen in carcinogenese. Door in vitro studies is aangetoond dat de genotoxische eigenschappen van deeltjes worden bepaald door diverse kenmerken zoals grootte, vorm, chemische samenstelling, kristalliniteit, oplosbaarheid, en reactiviteit van het deeltjesoppervlak. In vivo studies hebben echter laten zien dat tumorvorming in de rattelong niet zozeer afhankelijk is van de intrinsieke genotoxische activiteit van de deeltjes, maar meer een gevolg is van (chronische) inflammatoire processen. Dit betekent dat men ter bestudering van het mechanisme van deeltjes-genotoxiciteit een onderscheid dient te maken tussen primaire (door deeltjes veroorzaakte) en secundaire (door inflammatie veroorzaakte) genotoxische effecten. In beide processen speelt de productie van reactieve zuurstof species (RZS) een belangrijke rol. De doelstelling van dit proefschrift was om DNA schade te bestuderen in long epitheel cellen na blootstelling aan deeltjes. De nadruk lag hierbij vooral op de rol van RZS. In het eerste deel van het proefschrift (hoofdstukken 2-4) zijn mechanismen van primaire genotoxiciteit beschreven, terwijl in de hoofdstukken 5-7 speciale aandacht is gegeven aan secundaire genotoxische processen. Daarin ligt de nadruk op de specifieke rol van neutrofielen, omdat deze cellen mogelijk een belangrijke functie vervullen in secundaire genotoxiciteit in de rat. De studies zijn uitgevoerd met zowel PM als kwarts (DQ12). Van beide stoffen is bekend dat ze een verscheidenheid aan respiratoire aandoeningen kunnen veroorzaken, waaronder longkanker.

\section{Primaire genotoxiciteit}

In het eerste deel van het proefschrift (hoofdstukken 2-4) worden mogelijke mechanismen van primaire genotoxiciteit van kwarts en PM beschreven. De nadruk in deze studies lag voornamelijk op de functie van het hydroxyl radicaal $(\mathrm{OH})$, omdat dit het meest reactieve zuurstof species is. Daarnaast hebben in het verleden reeds verschillende studies indirect bewijs geleverd voor een mogelijke rol van ${ }^{\circ} \mathrm{OH}$ in de genotoxische effecten van PM en kwarts. Om te onderzoeken of PM en kwarts inderdaad ${ }^{\circ} \mathrm{OH}$ kunnen produceren is in de hoofdstukken 2-4 gebruik gemaakt van elektron spin resonantie (ESR). Hieruit bleek dat de vorming van ${ }^{\circ} \mathrm{OH}$ door beide stofdeeltjes in grote mate werd versterkt na toevoeging van waterstofperoxide $\left(\mathrm{H}_{2} \mathrm{O}_{2}\right)$. Dit duidt op een mogelijke rol van Fenton reacties, hetgeen impliceert dat transitie metalen betrokken zijn. De vorming van ${ }^{\circ} \mathrm{OH}$ door PM kon worden geblokkeerd door de toevoeging van deferoxamine. Dit suggereert dat ijzer een belangrijke rol speelt (hoofdstukken 2 en 3). Voor kwarts geldt dat de productie van ${ }^{\circ} \mathrm{OH}$ voor een groot deel verklaard kan worden door de reactiviteit van het deeltjes-oppervlak. Dit werd inderdaad bevestigd door (niet in dit proefschrift beschreven) experimenten waarin ${ }^{\circ} \mathrm{OH}$ productie door DQ12-kwarts kon worden gereduceerd na behandeling van het deeltjes-oppervlak met aluminium lactaat of polyvinylpyridine- $\mathrm{N}$-oxide (PVNO).

De gezamenlijke eigenschap van PM en kwarts om ${ }^{\circ} \mathrm{OH}$ te kunnen produceren duidt mogelijkerwijs op een overeenkomstig mechanisme dat betrokken is bij de primaire genotoxiciteit van beide deeltjes, zeker gezien de reactiviteit van het $\mathrm{OH}$-radicaal. Detectie van DNA strengbreuken en 8-hydroxydeoxyguanosine (8-OHdG) werden gebruikt als (semi-) specifieke methoden om DNA schade door ${ }^{\circ} \mathrm{OH}$ nader te bestuderen. In de hoofdstukken 2 en 3 werd aangetoond dat PM zowel DNA strengbreuken als 8-OHdG kan induceren in naakt DNA (plasmid-assay, dot-blot analyse). Dit effect bleek duidelijk te zijn gerelateerd aan de 
mogelijkheid van PM om ${ }^{\circ} \mathrm{OH}$ te produceren. Vergelijkbare experimenten toonden aan dat dit tevens het geval was voor kwarts.

Ook in cellulaire systemen is de primaire genotoxiciteit van PM en kwarts bestudeerd. Hiervoor is gebruik gemaakt van alveolaire epitheel cellen van zowel rat (RLE) als humane (A549) oorsprong. Alveolaire epitheel cellen worden gezien als een specifiek doelwit voor tumor vorming na langdurige blootstelling aan deeltjes. Zowel kwarts als PM veroorzaakten primaire DNA schade (8-OHdG en DNA strengbreuken) in beide cellijnen. Net als in kaal DNA bleek dat ook in de epitheel cellen een groot deel van de DNA schade, veroorzaakt door beide deeltjes, kon worden toegeschreven aan de vorming van ${ }^{\circ} \mathrm{OH}$. De ESR experimenten toonden aan dat de aanwezigheid van $\mathrm{H}_{2} \mathrm{O}_{2}$ een belangrijke factor is voor PM en kwarts om ${ }^{\circ} \mathrm{OH}$ te kunnen genereren. In hoeverre waterstofperoxide, mogelijk endogeen geproduceerd, een belangrijke rol speelt in de vorming van ${ }^{\circ} \mathrm{OH}$ in de epitheel cellen zal nog verder moeten worden uitgezocht.

Het is belangrijk om te realiseren dat PM en kwarts twee totaal verschillende soorten stofdeeltjes zijn. Dit impliceert dat er verschillende mechanismen ten grondslag kunnen liggen aan de vorming van ${ }^{\circ} \mathrm{OH}$ en de hieraan gerelateerde inductie van DNA schade. DQ12kwarts is grotendeels homogeen en bestaat voor ongeveer $90 \%$ uit kristallijn silica (de rest is amorf silica). PM daarentegen, heeft een zeer complexe en heterogene samenstelling. Het belangrijkste verschil is echter dat, in tegenstelling tot kwarts, een groot deel van PM oplosbaar is. In hoofdstuk 3 is aangetoond dat de onoplosbare deeltjes-fractie van PM mogelijkerwijs een bijdrage levert aan de cellulaire genotoxiciteit. Echter, de eigenschap van $\mathrm{PM}$ om $\mathrm{OH}$ te produceren en DNA te beschadigen bleek toch grotendeels de verantwoordelijkheid van water-oplosbare componenten. De belangrijkste factor hierin is waarschijnlijk ijzer (hoofdstukken 2 en 3). Voor kwarts is reeds aangetoond dat ${ }^{\circ} \mathrm{OH}$ productie voornamelijk kan worden toegeschreven aan de reactiviteit van het oppervlak van de onoplosbare deeltjes. Vanwege de extreem hoge reactiviteit van het $\mathrm{OH}$-radicaal zal het alleen met DNA kunnen reageren indien het ook in de directe omgeving hiervan is geproduceerd. Het is echter onwaarschijnlijk dat de waargenomen DNA schade een gevolg is van de productie van ${ }^{\circ} \mathrm{OH}$ direct aan het kwarts-oppervlak, zeker gezien het feit dat in de celkern geen kwartsdeeltjes konden worden gedetecteerd (niet gepubliceerde observaties).

Concluderend, de studies gepresenteerd in het eerste deel van dit proefschrift tonen aan dat PM en kwarts DNA schade kunnen veroorzaken in long epitheel cellen. Hierin blijkt een belangrijke rol te zijn weggelegd voor het hydroxyl radicaal. Het blijft echter onduidelijk of deze mechanismen van primaire in vitro genotoxiciteit ook in vivo een rol spelen. Verder moet men zich realiseren dat in werkelijkheid de samenstelling van zowel PM als kwarts variabel is. Dit impliceert dat de capaciteit van beide deeltjes om DNA schade te veroorzaken wordt bepaald door hun uiteindelijke fysieke en chemische eigenschappen. Dit houdt tevens in dat men voorzichtig moet zijn met het generaliseren van de mechanismen die mogelijk leiden tot een genotoxisch effect van PM en kwarts.

\section{Secundaire genotoxiciteit}

Op dit moment wordt gedacht dat de productie van RZS door fagocyten een belangrijke rol speelt in de secundaire genotoxische effecten van stofdeeltjes. In de rattelong wordt de inflammatoire response na blootstelling aan deeltjes gekenmerkt door een sterke toename van het aantal neutrofielen. Van alle fagocyten hebben de neutrofielen de grootste capaciteit om RZS te produceren. Dit suggereert dat in de rat de neutrofiel mogelijkerwijs een cruciale rol speelt in de genotoxische effecten van deeltjes. In de hoofdstukken 5 en 6 is aangetoond dat geactiveerde neutrofielen inderdaad 8-OHdG en DNA strengbreuken kunnen veroorzaken in RLE cellen. Hierbij is gebruik gemaakt van een in vitro co-incubatie model waarin RLE cellen worden blootgesteld aan neutrofielen. De data gepresenteerd in hoofdstuk 6 geven 
verder aan dat de productie van $\mathrm{H}_{2} \mathrm{O}_{2}$ door neutrofielen een belangrijke rol speelt in de vorming van DNA strengbreuken. Ook is aangetoond dat een direct contact tussen de neutrofiel en de target cel een voorwaarde is voor de inductie van DNA schade. Het feit dat 8OHdG wordt gevormd in de RLE cellen geeft aan dat een deel van de DNA schade veroorzaakt door neutrofielen kan worden verklaard door de intracellulaire productie van ${ }^{\circ} \mathrm{OH}$ (hoofdstuk 5). Hoofdstuk 6 beschrijft tevens een in vivo studie waarin de relatie tussen inflammatie en DNA schade in de humane neus werd onderzocht. In een groep van 80 kinderen werd bepaald in hoeverre het aantal neutrofielen in een neuslavage was gerelateerd aan DNA schade in epitheelcellen, verkregen door middel van een neusbrush. Met deze studie hoopten we de vraag te beantwoorden of neutrofielen ook genetische schade kunnen veroorzaken in de luchtwegen van de mens. Echter, er kon geen duidelijke correlatie worden waargenomen tussen de aanwezigheid van neutrofielen en de mate van DNA schade (8OHdG) in nasale epitheel cellen.

In Hoofdstuk 7 is een in vivo studie gepresenteerd waarin wordt aangetoond dat intratracheale instillatie van DQ12-kwarts gepaard gaat met de inductie van DNA strengbreuken in het long epitheel van de rat. In deze studie werden long epitheel cellen geïsoleerd, om zodoende DNA schade te kunnen bestuderen in cellen die een specifiek doelwit zijn voor carcinogeniteit veroorzaakt door stofdeeltjes. De mate van DNA schade (strengbreuken) kon worden gereduceerd wanneer de kwartsdeeltjes vooraf waren behandeld met de oppervlakte modificerende stoffen aluminium lactaat of PVNO. Deze experimenten tonen niet alleen aan dat kwarts in vivo DNA schade kan veroorzaken, maar leveren tevens een bewijs dat in dit proces een belangrijke rol is weggelegd voor de reactiviteit van het kwartsdeeltjes-oppervlak. Een andere belangrijke bevinding was dat de reductie van DNA schade door oppervlakte coating gepaard ging met een verminderde influx van inflammatoire fagocyten, en dan vooral neutrofielen.

Concluderend geven de studies in het tweede deel van dit proefschrift aan dat neutrofielen DNA schade kunnen veroorzaken in long epitheel cellen in vitro. Ook de in vivo studie van hoofdstuk 7 toont aan dat in de rat tenminste een deel van de DNA schade na blootstelling aan kwarts kan worden toegeschreven aan neutrofielen. De data bevestigen tevens de heersende opvatting met betrekking tot de cruciale rol van inflammatoire fagocyten in de (secundaire) genotoxische effecten van deeltjes in de rat. Indien DNA schade kan worden beschouwd als een pre-mutagene gebeurtenis, dan zijn de beschreven data tevens complementair met eerdere in vivo studies waarin werd aangetoond dat neutrofielen betrokken zijn bij mutagene effecten van kwarts in de rat (HPRT, p53). In hoeverre neutrofielen betrokken zijn bij genotoxische processen in de humane luchtwegen blijft echter onduidelijk.

\section{Deeltjes-genotoxiciteit in perspectief}

In dit proefschrift is een hele serie van verschillende experimenten gebruikt om de genotoxiciteit van deeltjes nader te bestuderen. De gebruikte methoden varieerden van acellulaire in vitro incubaties tot in vivo studies met ratten en mensen. Hierdoor was het mogelijk om primaire en secundaire genotoxiciteit van stofdeeltjes separaat te onderzoeken. De acellulaire chemische methoden beschreven in de hoofdstukken 2-4 kunnen worden beschouwd als een waardevol hulpmiddel om op een snelle en efficiënte manier deeltjesgenotoxiciteit te screenen. Echter, men moet zich realiseren dat zulke methoden, waar kaal DNA in direct contact wordt gebracht met relatief grote hoeveelheden stof, ver af staan van de werkelijkheid. Daarom kunnen deze experimenten alleen worden beschouwd als een aanvulling op cellulaire testmethoden. Genotoxiciteits-studies met als doel om het carcinogene risico van stofdeeltjes te bestuderen, moeten idealiter worden uitgevoerd met cellen die een relevant doelwit zijn voor de uiteindelijke ontwikkeling van een tumor. Dit geld zowel voor in vivo als in vitro studies. De methode zoals beschreven in hoofdstuk 7 schept de 
mogelijkheid om genotoxiciteit van stofdeeltjes te analyseren op een multifunctionele manier, omdat de bijdrage van diverse factoren, zoals inflammatie, toxiciteit en antioxidant capaciteit kan worden geanalyseerd binnen een enkel dier. Echter, zulke rat modellen zijn niet geschikt om de mechanismen van primaire en secundaire genotoxiciteit separaat te onderzoeken. In de rat gaat blootstelling aan deeltjes namelijk altijd gepaard met een bepaalde mate van inflammatie. Om beide processen individueel te kunnen onderzoeken, moeten meer verfijnde in vivo modellen worden ontwikkeld. Ook de specifieke rol van de neutrofiel verdient extra aandacht. De genotoxische activiteit van neutrofielen mag dan wel onomstotelijk zijn aangetoond in in vitro studies, de rol van de neutrofiel in genotoxiciteit in vivo is vooralsnog voornamelijk gebaseerd op associatieve waarnemingen in de aan stofdeeltjes blootgestelde rat. Daarnaast rest de vraag of de beschreven mechanismen van primaire en (door neutrofielen veroorzaakte) secundaire DNA schade van relevatie zijn voor de mens.

Tot slot: dit proefschrift beschrijft een aantal processen die mogelijk betrokken zijn bij primaire, dan wel secundaire DNA schade veroorzaakt door stofdeeltjes. Vooral met het oog op risicobeoordeling moet worden benadrukt dat genotoxiciteit alleen verwijst naar DNA reactiviteit. Ook al hebben onze studies aangetoond dat deeltjes (PM, kwarts), alsook neutrofielen, DNA schade kunnen veroorzaken in cellen die relevant zijn voor carcinogenese, de implicatie hiervan voor de uiteindelijke ontwikkeling van longtumoren zal nog verder moeten worden onderzocht. 


\section{Dankwoord/Acknowledgements}

$\mathrm{Ja}$, daar zit je dan, op een warme zaterdagmiddag ergens in juli 2002 , kort voor je vakantie. Het proefschrift is af en goedgekeurd, je bent al bij de drukker geweest voor een eerste afspraak, je werkt nog een beetje aan de lay-out van je 'boekje', en vanavond ga je nog 2 locaties voor een promotiefeest bezoeken. Kortom, het promovendus-leventje zit er bijna op. Echter, ik realiseer me terdege dat het niet zover had kunnen komen zonder de fantastische hulp van velen.

Allereerst natuurlijk Paul, mijn eerste promotor. Ik heb ontzettend veel vertrouwen geput uit het feit dat je me na mijn kortstondige 'klim-sabbatical' weer met open armen in Düsseldorf hebt ontvangen. Daarvoor alleen al: heel erg veel dank! Je begeleiding was fantastisch, met een optimale balans tussen het geven van vrijheid en (strak) coachen op momenten dat het nodig was. Ik bewonder je heldere en zakelijke kijk op de wetenschap en hoop ook in de toekomst nog veel samen met je te kunnen wetenschappen. Ik zal dan ook regelmatig bij je blijven aankloppen, al was het maar vanwege de wijn. Ook Aalt, mijn tweede promotor: hartstikke bedankt dat ik bij je mocht promoveren. We hebben relatief weinig samen gedaan, maar ik heb meer van je opgestoken dan je denkt. Je grenzenloos positieve instelling is een voorbeeld voor velen. En dan natuurlijk Roel, co-promotor, kamergenoot en vriend. Ik ken weinigen met een sneller werkend brein dan dat van jou. lk mis onze verhitte discussie- en brainstormsessies over wetenschap, sport en muziek nu al. Gelukkig is er nog e-mail of telefoon. Paul en Roel, jullie hebben me aangestoken met jullie enthousiasme voor het 'wetenschappers-vak'. Drie jaar samen, zo'n 15 uur per week (in totaal \pm 2000 uur) doorbrengen in een ruimte van ongeveer $3 \mathrm{~m}^{3}$ (= auto) schept een band. Ik ben er zeker van dat die ook na de promotie zal blijven bestaan. Bedankt!

I'm grateful to all my colleagues from the Department of Fibre \& Particle Toxicology, (MIU/IUF) for the great time in Düsseldorf. First of all, of course, I want to thank Astrid: without your help, this thesis would have been significantly smaller in size. Many thanks for your excellent technical assistance. Andrea: my arm still feels paralysed after chopping so many lungs. Thank you for your great help (type-II cell isolation and many, many other things). Catrin, 'mother' of the department, thank you that I could participate in your 'animal study'. Also many thanks for all the immunostaining-trouble-shooting. Your commitment to the department was incredible. Tingming, the Master of ESR, I'm greatly indebted to you for your help. Christel Weishaupt, for all your comet-work. Dünya, my room-mate: I'll never forget the Kebab in Berlin. Of course Gonca, your enthusiasm was catching. Doris: you made me realise that particle research without electron microscopy is like fishing without a fishingrod. Tobias, Christian, Chiara, Brigitte, Isabelle, Konnie, Yvonne, Veena, Kirstin, Gabriele and last but not least Karim, James and Seema who joined the club shortly before I left the department: Thank you/Herzlichen Dank!!

Ook de collega's van GRAT, waar ik in 1997-1998 een dik jaar als AIO heb gewerkt en waar hoofdstuk 5 tot stand is gekomen, wil ik bedanken voor de mooie tijd (1997-1998). Jos, ook al was je maar voor 1 jaar promotor: veel dank. Lou en Frederik-Jan, bedankt voor de hulp bij het post-labelen en het schrijven van manuscripten (ook al staan ze niet in dit proefschrift). Pauline voor het HPLC-en van $8-\mathrm{OHdG}$ en roddelen over van alles en nog wat. Roger (Labelen!) en Ingrid, mede-AIO's, voor het wegwijs maken in het AIO-wereldje. Ook alle andere mensen: Marcel (cellekes), Edwin (mister MS-AAS-HPLC), Manon (Nonnie, Sister in arms), Remko, Danielle, Theo, Ben, Jan D, Jan van M (Amsterdam-ESR connection), Patrick, Anke, Harma, Marie-Claire, Geja, Els, Irene and also Soedja, Zhai and Hamid en alle stagiaires: allemaal bedankt. Tevens wil ik ook mijn nieuwe GRAT collega's bedanken voor de alweer gezellige tijd. 
I would also like to thank some people from other departments and institutes: Prof. J. Bruch, Frank Seiler and Peter Nehls from the Institute of Hygiene and Occupational Medicine (University Essen): for the collaboration on 8-OHdG immunostainings. Guido Haenen van de capaciteitsgroep Farmacologie en Toxicologie (UM): bedankt voor de TEAC metingen.

People from Edinburgh: Rodger, Pete, Ellen, Vicki, Al and all others: Thank you for the good times (nights!) during meetings in Maastricht, Toronto, Berlin (especially Pete) and Cambridge. Keep in touch!

Leden van de beoordelingscommissie: Prof. E. Wouters, Prof. J. Bruch, Prof. C. Bruggeman, Prof. K. Donaldson en Prof. F. van Schooten: hartelijk dank voor de snelle beoordeling van het manuscript; Thank you for reviewing this thesis.

Al mijn klimvriendjes (Neoliet-gang), ongemerkt hebben jullie ook een steentje bijgedragen. Door het klimmen kom je letterlijk en figuurlijk in hogere sferen. Hierdoor kon de regelmatig terugkerende promotiestress aardig worden beteugeld!

Pap en Mam: jullie hebben altijd in mij geloofd, ook toen ik mijn wetenschappelijke 'carrière' na een jaar AIO-schap heb stopgezet. Jullie hebben mij meegegeven dat je altijd van je eigen gevoel uit moet gaan. Heel erg bedankt voor de geweldige steun.

En tenslotte natuurlijk Janneke, mijn heldin en rots in de branding. Jij deed mij inzien dat er meer is dan alleen maar werken en klimmen. Jouw nimmer aflatende interesse en vrolijkheid hebben mij ontzettend gesterkt.

\section{Allemaal bedankt!}




\section{Curriculum vitae}

Op 19 april 1972 werd ik geboren te St.-Geertruid. Na een fantastische jeugd begon ik op mijn $12^{\text {de }}$ met de middelbare school in Maastricht. Na het behalen van het VWO diploma, toog ik in augustus 1990 naar Amsterdam om aan de UvA Geneeskunde te gaan studeren. Ik was er namelijk stellig van overtuigd dat ik arts wilde worden. Echter, tijdens het eerste jaar werd mij al snel duidelijk dat ik vooral geïnteresseerd was in het fundamentele onderzoek binnen de medische wetenschap en besloot dan ook een studie te zoeken die mij daar meer specifiek voor zou opleiden. Mijn oog viel toen op Gezondheidswetenschappen in Maastricht, en wel de afstudeerrichting Biologische Gezondheidskunde. Aldus vertrok ik vol goede moed terug naar het zuiden en begon in september 1991 met mijn nieuwe studie. Hier kwam ik tevens in aanraking met het sportklimmen, wat al snel een belangrijk deel van mijn leven zou worden. $\mathrm{Na} 4$ jaar studeren, afgewisseld met ontelbare ritjes naar de mooie klimrotsen in Belgiẽ en vooral het zuiden van Frankrijk, begon ik in augustus 1995 met mijn afstudeerstage bij de vakgroep Gezondheidsrisico Analyse en Toxicologie (GRAT) aan de Universiteit Maastricht. Een jaar later (augustus 1996) studeerde ik uiteindelijk cum laude af als Gezondheidswetenschapper. Op 1 februari 1997 trad ik vervolgens als assistent in opleiding in dienst bij de vakgroep GRAT (Dr. Paul Borm, Prof. Jos Kleinjans), alwaar het onderzoek beschreven in hoofstuk 5 werd uitgevoerd. Echter, na 14 maanden besloot ik geheel vrijwillig te stoppen met de AIO-baan om mij full-time met klimmen bezig te gaan houden. Na een fantastische tijd, met jammer genoeg veel blessureleed, maakte ik een jaar later een 'restart' in de wetenschap. In juni 1999 werd ik voor 3 jaar aangesteld als wetenschappelijk medewerker bij de afdeling 'Fibre and Particle Toxicology' (Prof. Paul Borm) van het Medizinisches Institut für Umwelthygiene (tegenwoordig: Institut für umweltmedizinische Forschung) in Düsseldorf, alwaar het grootste deel van het in dit proefschrift beschreven onderzoek werd uitgevoerd. Vanaf juni 2002 ben ik als postdoc werkzaam bij (wederom) de vakgroep Gezondheidsrisico Analyse en Toxicologie aan de Universiteit Maastricht. 


\section{List of publications}

\section{Full Papers}

Borm PJA, Knaapen AM, Schins RPF, Godschalk RWL, Van Schooten FJ. Neutrophils amplify the formation of DNA-adducts by benzo[a]pyrene in lung target cells. Environ Health Perspect 105 (suppl 5): 1089-1093, 1997.

Knaapen AM, Seiler F, Schilderman PAEL, Nehls P, Bruch J, Schins RPF, Borm PJA. Neutrophils cause oxidative DNA damage in alveolar epithelial cells. Free Radic Biol Med 27: 234-240, 1999.

Van Maanen JMS, Borm PJA, Knaapen AM, Van Herwijnen M, Schilderman PAEL, Smith KR, Aust AE, Tomatis M, Fubini B. In vitro effects of coal fly ashes: Hydroxyl radical formation, iron release, and DNA damage and toxicity in rat lung epithelial cells. Inhal Toxicol 11: 1123-1141, 1999.

Knaapen AM, Schins RPF, Steinfartz Y, Hőhr D, Dunemann L, Borm PJA. Ambient particulate matter induces oxidative DNA damage in lung epithelial cells. Inhal Toxicol 12 (suppl 3): 125-132, 2000.

Knaapen AM, Den Hartog GJ, Bast A, Borm PJA. Ambient particulate matter induces relaxation of rat aortic rings in vitro. Hum Exp Toxicol 20: 259-265, 2001.

Hőhr D, Steinfartz Y, Schins RPF, Knaapen AM, Martra G, Fubini B, Borm PJA. The surface area rather than the surface coating determines the acute inflammatory response after instillation of fine and ultrafine $\mathrm{TiO}_{2}$ in the rat. Int J Hyg Environ Health 205: 239-244, 2002.

Knaapen AM, Shi T, Borm PJA, Schins RPF. Soluble metals as well as the insoluble particle fraction are involved in cellular DNA damage induced by particulate matter. Mol Cell Biochem 234/235: 317-326, 2002.

Knaapen AM, Schins RPF, Polat D, Becker A, Borm PJA. Mechanisms of neutrophil-induced DNA damage in respiratory tract epithelial cells. Mol Cell Biochem 234/235: 143-151, 2002.

Schins RPF, Knaapen AM, Cakmak GD, Shi T, Weishaupt C, Borm PJA. Oxidant-induced DNA damage by quartz in alveolar epithelial cells. Mutat Res 517: 77-86, 2002.

Knaapen AM, Albrecht C, Becker A, Höhr D, Winzer A, Haenen GR, Borm PJA, Schins RPF. DNA damage in lung epithelial cells isolated from rats exposed to quartz: role of surface reactivity and neutrophilic inflammation. Carcinogenesis 23: 1111-1120, 2002.

Schins RPF, Duffin R, Höhr D, Knaapen AM, Shi T, Weishaupt C, Stone V, Donaldson K, Borm PJA. Surface modification of quartz inhibits toxicity, particle uptake, and oxidative DNA damage in human lung epithelial cells. Chem Res Toxicol, in press.

Shi T, Knaapen AM, Begerow J, Birmili W, Borm PJA, Schins RPF. Temporal variation of hydroxyl radical generation and 8-hydroxy-2'-deoxyguanosine formation by coarse and fine particulate matter. Occup Environ Med, submitted.

\section{Short communications}

Albrecht C, Becker A, Schins RPF, Höhr D, Unfried K, Knaapen AM, Borm PJA. Importance of surface characteristics of DQ12 quartz for acute inflammation. Annals Occup Hygiene 46 (suppl 1): $22-26,2002$.

Becker A, Albrecht C, Schins RPF, Knaapen AM, Höhr D, Unfried K, Borm PJA. In vivo and in vitro expression of CYP1Al in rat epithelial cells after instillation of quartz. Annals Occup Hygiene 46 (suppl 1): 31-34, 2002.

Schins RPF, Knaapen AM, Weishaupt C, Winzer A, Borm PJA. Cytotoxic and inflammatory effects of coarse and fine particulate matter in macrophages and epithelial cells. Annals Occup Hygiene 46 (suppl 1): 203-206, 2002.

Borm PJA, Polat D, Knaapen AM, Becker A, Schins RPF. Oxidative DNA damage in nasal epithelium is not related to nasal inflammation. Annals Occup Hygiene 46 (suppl 1): 393-396, 2002. 


\section{Abstracts (selection)}

Borm PJA, Godschalk RWL, Knaapen AM, Zwingmann IH, Schins RPF, Driscoll KE. Neutrophils amplify benzo[a]pyrene-DNA adduct formation in alveolar epithelial cells. Am J Respir Crit Care Med 153(4): A511, 1996.

Knaapen AM, Schins RPF, Godschalk RWL, Borm PJA. DNA adducts and oxidative damage in lung epithelial cells coincubated with neutrophils and benzo[a]pyrene. The 6th int. meeting on the toxicology of natural and man-made fibrous and non-fibrous particles. September 15-18, Lake Placid, New York, 1996.

Pennings HJ, Knaapen AM, Borm PJA, Wouters EFM. Beclomethasone dipropionate increases catalase activity in erythrocytes of patients with stable asthma. Eur Respir J 9 (suppl 23): 1s, 1996.

Schins RPF, Knaapen AM, Schilderman PAEL, Driscoll KE, Van Schooten FJ, Borm PJA. Reactive oxygen species generated by neutrophils enhance both oxidative DNA damage and benzo[a]pyrene-DNA adduct formation in alveolar epithelial cells. Proc Am Ass Cancer Res 38: 336, 1997 .

Schins RPF, Knaapen AM, Jetten MA, Borm PJA. Cell counts and inflammatory mediators in nasal lavage evaluated in two protocols using a cross-over design: A wash out effect? Eur Respir $J 10$ (suppl. 25): 257s, 1997.

Borm PJA, Schins RPF, Van Herwijnen M, Knaapen AM, Schilderman PAEL, Van Maanen JMS, Fubini B. Inflammatory and (geno)toxic effects of coal-fly ashes (CFA) in relation to its quartz content. Am Rev Respir Crit Care Med 157: A150, 1998.

Knaapen AM, Schins RPF, Steinfartz Y, Hőhr D, Dunemann L, Borm PJA. Hydroxyl radical generation by airborne particulates detected by electron spin resonance and biological assays. $7^{\text {th }}$ International Symposium on Particle Toxicology. Maastricht. The Netherlands, 13-15 october, 1999

Knaapen AM, Schins RPF, Steinfartz Y, Höhr D, Dunemann L, Borm PJA. Ambient particulate matter causes oxidative DNA damage in lung target cells. Am J Respir Crit Care Med 161, A913, 2000.

Schins RPF, Knaapen AM, Donaldson K, Borm PJA. Oxidative DNA damage and strand break formation in alveolar epithelial cells by quartz and quartz containing dusts. Am J Respir Crit Care Med 161, A53, 2000.

Borm PJA, Schins RPF, Knaapen AM, Höhr D, Dunemann L. Radical generation capacities of ambient particulate matter in relation to its genotoxicity. Toxicol Sci 54 (suppl 1): 231:2000.

Knaapen AM, Den Hartog GJ, Bast A, Borm PJA. Ambient particulates but not ultrafine $\mathrm{TiO}_{2}$ induce relaxation of rat aorta in vitro. Eur Respir J 16 (Suppl 31): 292S, 2000.

Schins RPF, Polat D, Becker A, Knaapen AM, Borm PJA. In vitro and in vivo effects of ambient particulates. J Aerosol Sci 31 (suppl 1): S33-S34, 2000.

Knaapen AM, Schins RPF, Costabel U, Borm PJA. Human lung phagocytes induce oxidative DNA damage in epithelial cells in vitro. Am J Respir Crit Care Med 163:A876, 2001.

Schins RPF, Knaapen AM, Shi T. Weishaupt C, Borm PJA. Oxidative DNA damage in alveolar epithelial cells by ambient particulate matter. Am J Respir Crit Care Med 163:A172, 2001.

Schins RPF, Shi T, Knaapen AM. Begerow J. Borm PJA. Oxidant capacity and watersoluble transition metals in fine and coarse particulate matter. Toxicol Sci 60 (suppl 1): 192, 2001.

Knaapen AM, Becker B, Albrecht A, Schins RPF, Winzer A, Weishaupt C, Borm PJA. Induction of DNA damage in lung epithelial cells from rats exposed to quartz: role of surface reactivity and neutrophilic inflammation. Inhaled particles, 2001, Cambridge (Oral presentation).

Polat D, Becker A, Schins RPF, Höhr D, Knaapen AM, Borm PJA. Nasal inflammation among children living in different areas of Germany. Eur Respir J 18 (suppl 33): 278s, 2001.

Schins RPF, Knaapen AM, Cakmak G, Shi T, Weishaupt C, Borm PJA. Oxidant-induced DNA damage by quartz and hydrogen peroxide in alveolar epithelial cells. Society of Toxicology, Annual congress 2002 .

\section{Scientific reports}

Borm PJA, Albrecht C, Becker A, Knaapen A, Cakmak G, Höhr D, Duffin R. Clouter A, Donalson K. Schins RPF. The variability of the quartz hazard: studies with workplace, commercial and model quartzes. Document prepared for the SCOELScientific Committee on Occupational Exposure Limits (EU), 2002. 



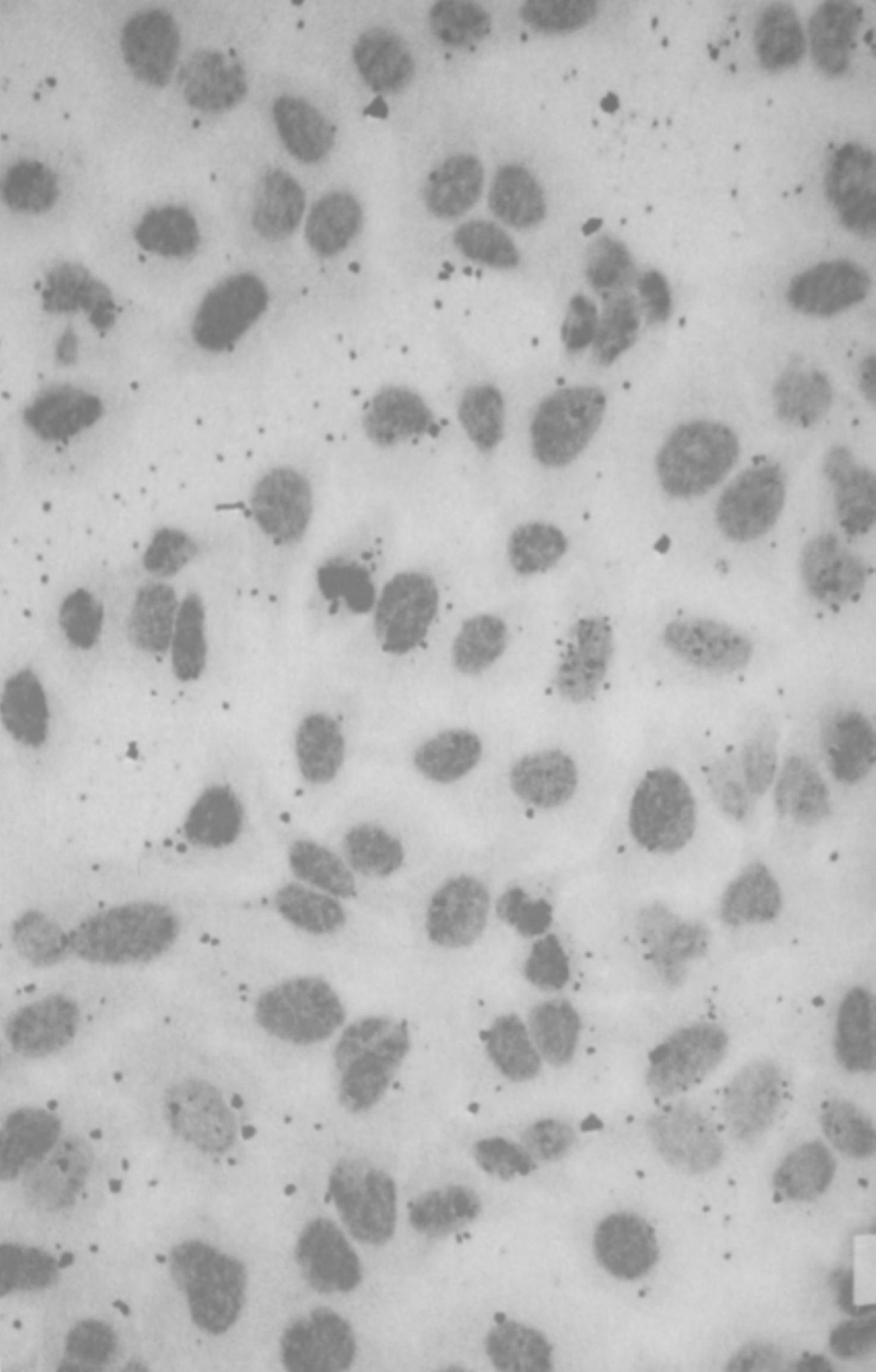

